NUREG/CR - 4095

SAND84-2628

RV

Printed March 1985

\title{
Test Series 2: Seismic-Fragility Tests of Naturally-Aged Class 1E Exide FHC-19 Battery Cells
}

Lloyd L. Bonzon, Donald B. Hente

Prepared by

Sandia National Laboratories

Albuquerque, New Mexico 87185 and Livermore, California 94550

for the United States Department of Energy

under Contract DE-AC04-76DP00789 


\section{DISCLAIMER}

This report was prepared as an account of work sponsored by an agency of the United States Government. Neither the United States Government nor any agency Thereof, nor any of their employees, makes any warranty, express or implied, or assumes any legal liability or responsibility for the accuracy, completeness, or usefulness of any information, apparatus, product, or process disclosed, or represents that its use would not infringe privately owned rights. Reference herein to any specific commercial product, process, or service by trade name, trademark, manufacturer, or otherwise does not necessarily constitute or imply its endorsement, recommendation, or favoring by the United States Government or any agency thereof. The views and opinions of authors expressed herein do not necessarily state or reflect those of the United States Government or any agency thereof. 


\section{DISCLAIMER}

Portions of this document may be illegible in electronic image products. Images are produced from the best available original document. 


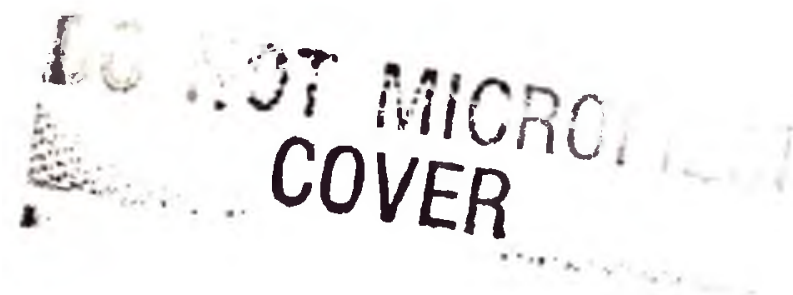

\section{NOTICE}

This report was prepared as an account of work sponsored by an agency of the United States Government. Neither the United States Government nor any agency thereof, or any of their employees, makes any warranty, expressed or implied, or assumes any legal liability or responsibility for any third party's use, or the results of such use, of any information, apparatus product or process disclosed in this report, or represents that its use by such third party would not infringe privately owned rights.

Available from

GPO Sales Program

Division of Technical Information and Document Control

U.S. Nuclear Regulatory Commission

Washington, D.C. 20555

and

National Technical Information Service

Springfield, Virginia 22161 
NUREG / CR-4095

SAND8 4-2628

TI85 013845

RV

\begin{abstract}
TEST SERIES 2: SEISMIC-FRAGILITY TESTS OF
NATURALLY-AGED CLASS 1E EXIDE FHC-19 BATTERY CELLS
\end{abstract}

March 1985

Lloyd L. Bonzon

Donald B. Hente

Sandia National Laboratories

Albuquerque, New Mexico 87185

operated by

Sandia Corporation

for the

U.S. Department of Energy

Appendices Prepared by

Bharat M. Kukreti

Jerry Schendel

James D. Tulk

W. John Janis

David A. Black

Gordon D. Paulsen

Brian D. Aucoin

Ontario Hydro

Toronto, Ontario, Canada

Performed under Sandia Contract No. 47-4077

Prepared for

Electrical Engineering Instrumentation and Control Branch

Division of Engineering Technology

Office of Nuclear Regulatory Research

U.S. Nuclear Regulatory Commission

Washington. DC 20555

Under Memorandum of Understanding 40-550-75

NRC FIN No. A-105I

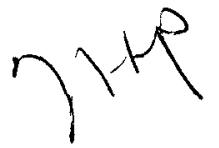




\section{Related Publications in this series}

- L. L. Bonzon and D. B. Hente. "Test series 1: SeismicFragility Tests of Naturally-Aged Class IE Gould NCX-2250 Battery Cells." SAND84-1737. NUREG/CR-3923, Sandia National Laboratories, Albuquerque, New Mexico. September 1984.

- L. L. Bonzon and D. B. Hente, "Test Series 2: SeismicFragility Tests of Naturally-Aged Class IE Exide FHC-19 Battery Cel1s," SAND84-2628, NUREG/CR-4095, Sandia National Laboratories. Albuquerque, New Mexico, March 1985.

- L. L. Bonzon and D. B. Hente. "Test Series 3: SeismicFragility Tests of Naturally-Aged Class 1E C\&D LCU-13 Battery Cells," SAND84-2629, NUREG/CR-4096, Sandia National Laboratories. Albuquerque, New Mexico. March 1985.

- L. L. Bonzon and D. B. Hente, "Test Series 4: SeismicFragility Tests of Naturally-Aged Exide EMP-13 Battery Cells," SAND84-2630, NUREG/CR-4097. Sandia National Laboratories, Albuquerque. New Mexico, March 1985.

- L. L. Bonzon and D. B. Hente, "Seismic-Fragility Baseline Tests of New Class 1E Battery Cells." SAND84-2631. NUREG/CR-4098, Sandia National Laboratories, Albuquerque, New Mexico. (To be published).

- L. L. Bonzon and D. B. Hente, "Age-Related Degradation of Naturally-Aged Class lE Battery Cells." SAND84-2632. NUREG/CR-4099. Sandia National Laboratories. Albuquerque. New Mexico. (To be published). 


\section{ABSTRACT}

The seismic-fragility of naturally-aged nuclear station safetyrelated batteries is of interest for two reasons: (1) to determine actual failure modes and their thresholds and (2) to determine the validity of using the electrical capacity of individual cells as an indicator of the "end-of-life" of a battery if subjected to a seismic event. This report. the second in a test series of an extensive seismic research program. covers the testing of 10-year old lead-calcium Exide FHC-19 cells from the Calvert Cliffs Nuclear Power station operated by the Baltimore Gas and Electric Company.

The Exide cells were tested in two configurations using a triaxial shake table: single-cell tests, both rigidly and loosely mounted: and multicell (three-cell) tests, mounted in a typical battery rack. The rigid. single-cell tests were done in two stages. The first stage exposed the cells to a simulated seismic event with peak zero period accelerations (ZPA) up to approximately $1.5 \mathrm{~g}$. The second stage exposed some of the same cells to a higher seismic intensity with a ZPA of approximately 2 g. In general the test philosophy was to monitor the electrical properties (including discharge capacity) of cells through a graduated series of increasing ZPA g-level steps until either the shake-table limits were reached or until electrical "failure" of the cells occurred.

A total of six electrically active cells was used in the two different cell configurations. None of the six cells failed in the first stage tests during the actual seismic test up to the $1.5 \mathrm{~g}$ ZPAs imposed. Subsequent discharge capacity tests showed. however, that only two of the cells could deliver the accepted standard of $80 \%$ of their rated electrical capacity for three hours. When two of the same cells were exposed to the second stage, higher g-level tests, both cells again provided instantaneous uninterrupted power. Subsequent capacity tests showed both of these cells to have capacities well below the accepted standard of $80 \%$.

Four of the cells were disassembled for examination and metallurgical analyses. The examination showed the active material on the positive plates was hard and cracked and that the positive bus bar material was corroded and brittle. Subsequent observation of the exposed cross-sections of the bus bars of two cells showed the area available for conduction to be just over $50 \%$ of original. The rest of the area had been reduced to lead oxide through chemical attack by sulphuric acid. Active material was also lost from the positive plates and, to a large degree. that loss contributed to the reduced electrical capacity of the cells. Active material on the positive plates also showed a slight expansion due to grid growth. 
CONTENTS

Page

Executive summary. . . . . . . . . . . . . . 1

1.0 Background. . . . . . . . . . . . . . . . . 3

1.1 General. . . . . . . . . . . . . . . . 3

1.2 Historical and Programmatic Perspective. . . . 3

2.0 Program objectives. . . . . . . . . . . . . . 3

2.1 Evaluation of Battery Aging Methodologies. . . . 3

2.2 Seismic-Fragility Testing of Batteries..... . 4

3.0 Approach and Report Format. . . . . . . . . . . . 4

3.1 Report Format. . . . . . . . . . . . . 5

4.0 Seismic-Fragility Tests of

Naturally-Aged Exide FHC-19 Cells . . . . . . . . . 6

4.1 Cell Selection and Condition . . . . . . . . . . 6

4.2 Results During Seismic-Fragility Tests . . . . . 6

4.3 Postseismic Capacity Tests . . . . . . . . . . . 9

4.4 Posttest Disassembly and Evaluation....... 10

5.0 Conclusions and Recommendations........... 11

6.0 References. . . . . . . . . . . . . . 13

Appendices . . . . . . . . . . . . . . . A-i 
Blank Page 


\section{FORWARD AND ACKNOWLEDGEMENTS}

This work was performed at the ontario Hydro Research Center, Toronto, Ontario, Canada, under Sandia National Laboratories (SNL) contract 47-4077. It covers the period from July 1 , through December 31, 1984. The sNL technical project monitors are Lloyd L. Bonzon and Donald B. Hente.

The overall development and execution of this program were carried out by Mr. B. M. Kukreti assisted by Mr. J. Schendel of the Electrical Design Department. Dr. James D. Tulk of the Applied Structural and Solid Mechanics Section, Mechanical Research Department, provided the expertise in seismic technology and coordinated the research activities. Messrs. D. A. Black and G. D. Paulsen of the Mechanical Testing and Development Section. Mechanical Research Department, provided expertise in seismic testing. Messrs. W. John Janis and B. D. Aucoin of the Chemical Research Department performed the seismic testing and subsequent cell disassembly. 


\section{EXECUTIVE SUMMARY}

The seismic-fragility of naturally-aged nuclear station safetyrelated batteries is of interest for two reasons: (1) to determine actual failure modes and their thresholds and (2) to determine the validity of using the electrical capacity of individual cells as an indicator of the "end-of-life" of a battery if subjected to a seismic event. This report. the second in a test series of an extensive seismic research program. covers the testing of 10-year old lead-calcium Exide FHC-19 cells from the Calvert cliffs Nuclear Power station operated by the Baltimore Gas and Electric Company.

The Exide cells were tested in two configurations using a triaxial shake table: single-cell tests, both rigidly and loosely mounted: and multicell (three-cell) tests. mounted in a typical battery rack. The rigid, single-cell tests were done in two stages. The first stage exposed the cells to simulated seismic event with peak zero period accelerations (ZPA) up to approximately $1.5 \mathrm{~g}$. The second stage exposed some of the same cells to a higher seismic intensity with a ZPA of approximately $2 \mathrm{~g}$. In general the test philosophy was to monitor the electrical properties (including discharge capacity) of cells through a graduated series of increasing ZPA g-level steps until either the shake-table limits were reached or until electrical "failure" of the cells occurred.

A total of six electrically active cells was used in the two different cell configurations. None of the six cells failed in the first stage tests during the actual seismic test up to the $1.5 \mathrm{~g}$ ZPAs imposed. Subsequent discharge capacity tests showed, however, that only two of the cells could deliver the accepted standard of $80 \%$ of their rated electrical capacity for three hours. When two of the same cells were exposed to the second stage, higher g-level tests, both cells again provided instantaneous uninterrupted power. Subsequent capacity tests showed both of these cells to have capacities well below the accepted standard of $80 \%$.

Four of the cells were disassembled for examination and metallurgical analyses. The examination showed the active material on the positive plates was hard and cracked and that the positive bus bar material was corroded and brittle. Subsequent observation of the exposed cross-sections of the bus bars of two cells showed the area available for conduction to be just over $50 \%$ of original. The rest of the area had been reduced to lead oxide through chemical attack by sulphuric acid. Active material was also lost from the positive plates and to a large degree that loss contributed to the reduced electrical capacity of the cells. These cells also showed slight grid growth. 
This grid/plate growth should be useful data in confirming the presently accepted accelerated-aging methods for qualifying batteries which is based on plate growth.

This effort is a subpart of a broader program to evaluate the accelerated aging methods used in qualifying Class $1 \mathrm{E}$ batteries (e.g.. in IEEE std 535-1979). BY seismic-fragility testing naturally-aged battery cells, the actual failure modes and their thresholds can be determined. This determination serves to focus the evaluation and development of other aging methods on those specific failure modes. thresholds, and locations that have been observed.

Other activities that are in progress include: (1) "baseline" examination and seismic testing of new, same type, cells from the three manufacturers of Class $1 \mathrm{E}$ batteries: (2) accelerated aging of new, same type, cells and subsequent seismic testing: (3) accelerated-aging of naturally-aged cells to an 18-year age and subsequent seismic testing: (4) compiling of typical nuclear plant required response spectra for comparison with the fragility levels experienced in these and follow-on tests: and (5) additional lead-chemistry evaluations of battery internal components. 


\subsection{BACKGROUND}

\subsection{General}

The seismic fragility of naturally-aged nuclear station safetyrelated batteries is of interest for two reasons: (1) to determine actual failure modes and their thresholds and (2) to determine the validity of using the electrical capacity of individual cells as an indicator of the "end-of-life" of a battery if subjected to a seismic event.

\subsection{Historical and Programmatic Perspective}

The concern over the seismic susceptibility of nuclear station safety-related batteries was generated by the number of battery problems that periodically had been reported in Licensee Event Reports (LERs).1-8* Following the problems reported at the Connecticut Yankee station, 8 the NRC conducted an investigation which concluded that aged batteries may be vulnerable to common-mode failures because of a seismic event. 9 The NRC then issued Information Notice 83-11, Possible Seismic Vulnerability of old Lead storage Batteries on March 14, 1983, to make nuclear power plant personnel aware of the finding. 10

Increasing concern over the possible adverse behavior of aged batteries in seismic events resulted in the NRC-sponsored Qualification Testing Evaluation (QTE) research program initiating an effort to evaluate the adequacy of batteries to survive seismic acceleration levels.ll These series of reports are the initial efforts of that research program.

\subsection{PROGRAM OBJECTIVES}

2.1 Evaluation of Battery Aging Methodologies**

The overall research programl has these seven main objectives:

1. To determine seismic failure modes and thresholds, primarily using naturally-aged cells.

2. To identify the dominant aging mechanism(s) through this testing experience, in conjunction with other test experience and expert evaluations.

*Reference 1 contains more detail on the historical and programmatic perspective.

**The overall program is discussed in greater detail in Reference 12 . 
3. To compare the response of naturally-aged cells to the response of new cells aged by the accelerated methods described in IEEE std. 535-1979 and to compare dominant failure modes in both cases.

4. To identify appropriate accelerated aging methodologies for the dominant failure mode(s).

5. To demonstrate those accelerated aging methodologies through a specific demonstration test program.

6. To make final recommendations for appropriate acceleratedaging methodology(ies) for nuclear station batteries.

7. To develop in situ testing methods which can predict the remaining age and seismic "tolerance" of batteries.

\subsection{Seismic-Fragility Testing of Batteries*}

The seven objectives of the overall program can be grouped into four subprograms or goals. Objectives $1-3$ relate to an effort to determine by test the actual failure modes and thresholds experienced in natural aging. Objectives 3-5 relate to an effort to compare/correlate current accelerated-aging methods and to recommend, develop, and prove modified aging methods based on the dominant failure modes observed. Objectives 5-6 lead to recommended aging method changes and incorporation into appropriate standards and guides. Objective 7 will lead to a predictive technique to determine "end-of-qualified" life of batteries.

This report covers the second in a test series to determine the seismic fragility of naturally-aged battery cells: thus, it corresponds to the subgroup defined by objectives $1-3$ above and continues the effort of the first test series.l

\subsection{APPROACH AND REPORT FORMAT}

Naturally-aged, Class $1 E$, battery cells have been obtained from four nuclear power stations in the United states and sent to the ontario Hydro Research Center for cell conditioning and subsequent seismic testing and analyses. All three

\footnotetext{
*The specifics of the seismic-fragility testing program are discussed in greater detail in Reference 13.
} 
manufacturers of Class $1 \mathrm{E}$ batteries are represented among the four groups of cells obtained. The Test series 1 report 1 discussed the results of testing 12-year old Gould NCX-2250 battery cells. This report discusses the results of seismic testing 10-year old Exide FHC-19 battery cells obtained from the Calvert Cliffs Nuclear Power station, courtesy of the Baltimore Gas and Electric Company. (No preference of treatment for testing or suspected failure should be implied from order of testing: the cells were tested in the order received.)

The details of the testing are summarized in the Appendices to this report. The generic approach followed this pattern: cell conditioning and pretest electrical capacity measurements were made; cells were exposed to simulated seismic (fragility) tests in both single and multicell configurations: posttest electrical capacity checks were made on cells which "survived"; selected cells were disassembled and evaluated; and the results were analyzed and reported.

\subsection{Report Format}

Ontario Hydro staff performed all testing and analyses; their results, presented in five stand-alone reports, are included as Appendices :

A: Simulated Earthquake Testing of Naturally Aged Exide FHC-19 Station Battery Cells

B: Seismic Testing of Calvert cliffs Nuclear Power station Batteries-Cell Inspection and Capacity Tests

C: Seismic Testing of North Anna and Calvert Cliffs Nuclear Power Station Batteries - Second Stage - High Table Accelerations

D: Seismic Testing of Calvert Cliffs N.P.P. Batteries (Exide FHC-19)

E: Seismic Re-testing of Calvert Cliffs Nuclear Power Plant Batteries at Increased Accelerations

Appendix $A$ is the collection and summary of the complete ontario Hydro effort along with results and conclusions sections.

Appendix B describes the preseismic cell conditioning, pre- and postseismic electrical capacity tests, and the results of both the first stage (to $1.5 \mathrm{~g}$ ZPAs) single-cell and multicell configurations and the cell disassembly. Addendum 1 to Appendix $B$ report provides cell specifications provided by the battery 
manufacturer: Addendum 2 provides discharge data obtained during the seismic tests: Addendum 3 provides the calculations to convert discharge times at the 1 -hour rate to the 3 -hour rate; and Addendum 4 gives the postmortem information on the disassembled cells.

Appendix $C$ describes the pre- and postseismic electrical capacity tests and results of the second stage--high intensity (to 2 g zPAs) seismic accelerations--single-cell configuration. Addendum 1 to Appendix $C$ provides cell specifications and Addendum 2 provides the discharge data obtained during the tests.

Appendix D and Appendix E report on the seismic testing of the cells during the first and second stage tests, respectively. Both reports describe the test procedures followed, the test equipment used, and interpret the results of the tests. Figures show the response spectrum in each of the $X, Y$, and $Z$ axes from accelerometers located both on a terminal post of the cell and on the base of the shake-table mounting jig.

In addition. Sections 4 and 5 which follow, draw from the Appendices the salient results, conclusions, and recommendations.

\subsection{SEISMIC-FRAGILITY TESTS OF NATURALLY-AGED EXIDE FHC-19 CELLS}

4.1 Cell selection and condition

After retiring a 60-cell 10-year old battery from service at the Calvert Cliffs Nuclear Power Plant. Baltimore Gas and Electric Company personnel selected 15 cells as potential spares and placed them on float charge. Subsequently. 10 of those 15 cells were selected for this test program.

Although all of the cells had lost capacity while in service. nine of the 10 cells had a rated electrical capacity of $86 \%$ or better as measured in a standard three-hour test. The tenth cell had a $67 \%$ capacity and was not used in this test series. Thus the nine cells used for these tests were not degraded to beyond an "end-of-life" condition.

\subsection{Results During Seismic-Fragility Tests}

The Appendices describe the test methods, results, and analyses in detail. Only the results are highlighted here as summarized in Tables $1-3$. As noted previously, the single cells were 
Table 1

Seismic-Fragility Test Results

single-Cell Tests - First stage

\begin{tabular}{|c|c|c|c|}
\hline $\begin{array}{c}\text { Cell } 1 \\
\text { No. }\end{array}$ & $\begin{array}{l}\text { Run } \\
\text { Sequence* }\end{array}$ & $\begin{array}{l}\text { ZPA Response } \\
\text { Levels-g** } \\
(x / y / z)\end{array}$ & Comments \\
\hline 15 & $\begin{array}{l}1 \\
2 \\
3 \\
4 \\
5\end{array}$ & $1.26 / 1.15 / 1.4 * * *$ & $\begin{array}{l}\text {-Battery mounting } \\
\text { clamps loose }\end{array}$ \\
\hline 35 & $\begin{array}{l}1 \\
2 \\
3 \\
4\end{array}$ & $1.21 / 1.71 / 1.22$ & \\
\hline 51 & $\begin{array}{l}1 \\
2 \\
3 \\
4 \\
5\end{array}$ & $1.29 / 2.24 / 1.4$ & $\begin{array}{l}\text {-No Y axis } \\
\text {-Retest } \\
\text {-Battery mounting } \\
\text { clamps loose }\end{array}$ \\
\hline 57 & $\begin{array}{l}1 \\
2 \\
3 \\
4 \\
5 \\
6\end{array}$ & $1.31 / 0.98 / 1.59$ & $\begin{array}{l}\text {-No load applied } \\
\text {-Load on }\end{array}$ \\
\hline
\end{tabular}

* The acceleration levels were generally increased for each run listed. so the runs imply cumulative severity.

** As measured on the shake table base mounting plate.

*** This run spectral data are plotted and available in the Appendices. 


\section{Table 2}

Seismic-Fragility Test Results

Single-Cell Tests - Second stage

\begin{tabular}{|c|c|c|c|}
\hline $\begin{array}{c}\text { Cell } \\
\text { No. }\end{array}$ & $\begin{array}{l}\text { Run } \\
\text { Sequence* }\end{array}$ & $\begin{array}{l}\text { ZPA Response } \\
\text { Levels }-g^{\star *} \\
(x / y / z)\end{array}$ & Comments \\
\hline 23 & $\begin{array}{l}1 \\
2\end{array}$ & 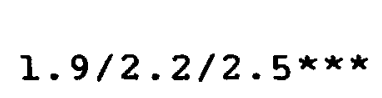 & \\
\hline 51 & $\begin{array}{l}1 \\
2\end{array}$ & $1.9 / 2.8 / 2.7$ & \\
\hline
\end{tabular}

Table 3

Seismic-Fragility Test Results

Multicell Tests

\begin{tabular}{llll}
\hline $\begin{array}{c}\text { Cell } \\
\text { No. }\end{array}$ & $\begin{array}{l}\text { Run } \\
\text { Sequence* }\end{array}$ & $\begin{array}{l}\text { ZPA Response } \\
\text { Levels }-g^{* *} \\
(\mathrm{X} / \mathrm{Y} / \mathrm{z})\end{array}$ & Comments \\
\hline $10.15,23$ & 1 & & \\
& 2 & & \\
3 & 4 & $1.13 /-/ 1.13 * \star *$ & $-Y$ axis signal \\
& & & distorted \\
\hline
\end{tabular}

Footnotes for Tables 2 and 3 above:

* The acceleration levels were generally increased for each run listed. so the runs imply cumulative severity.

* As measured on the shake table base mounting plate.

*** This run spectral data are plotted and available in the Appendices. 
exposed to increased levels of seismic shaking in two stages. No electrical or mechanical failure modes were noted for any of the cell configurations at any of the acceleration levels attained.

The ZPA response levels are the zero period accelerations of a normalized spectrum fitted to the experimental data over the 4 to $33 \mathrm{~Hz}$ range. The ZPA is used to express the intensity of the seismic motion of a typical seismic environment. The zPAs shown are for the spectra when the shake table limits were reached.

In the first stage tests (Table 1), the cells were exposed to accelerations up to ZPA levels of about $1.5 \mathrm{~g}$. In the second stage tests ( $\mathrm{Table} 2$ ). cells 23 and 51 (which had been previously used in the stage 1 tests) were exposed to even higher seismic excitations in anticipation that failures would develop from higher $g$-level input on the order of $2 \mathrm{~g}$ ZPA. Other than a slight separation of the cover and the jar on both cells, no failure modes were observed at the higher g-levels.

The single cells 1 isted in Tables 1 and 2 were rigidly mounted to the shake table in a jig designed to minimize relative motion between the table and the cell jar. This rigid mounting was intended to investigate the failure modes (if any) of the internal components of the cells (e.g.. lead plates, lead hangers, and the like).

The three cells listed in Table 3 (cells 10, 15, 23) were mounted in a multicell battery rack configuration based on the design of a "typical" seismically-qualified station battery rack. The purpose for this configuration was to check for (1) the influences of the rack-to-cells and cell-to-cell interactions on the cell responses and (2) the effect of typical rigid cell-to-cell electrical couplers between cell terminal posts. Overall, there seemed to be no particular differences in cell response as a result of testing in the single or multicell configurations.

\subsection{Postseismic Capacity Tests}

Following both the first and second stage seismic tests, the cells were measured for their electrical discharge capacities. The results of those measurements are shown in Table 4 . For the first stage seismic tests (the first six entries), the measurements showed that four of the six cells failed to meet the accepted criterion of $80 \%$ at the end of the three-hour discharge test. Following the second stage seismic tests, both cells had capacities that were much lower than the accepted criterion of 80\%. The extremely low-discharge capacity of cell 23 may be 


\section{Table 4}

Cell Capacities Before and After Seismic Testing (Given in Percent of Rated Electrical Capacity)

\begin{tabular}{ccc}
\hline & Before Testing & After Testing \\
\hline 10 & 100 & 66 \\
15 & 86 & 73 \\
23 & 86 & 75 \\
35 & 86 & 73 \\
51 & 94 & 98 \\
57 & 100 & 91 \\
$23 *$ & 75 & 33 \\
$51 *$ & 98 & 53 \\
& & \\
$*$ & Cel1s 23 and 51 were recharged prior to the start \\
& of the second stage seismic testing.
\end{tabular}

indicative of the fact that it had a very poor charge acceptance during float charge. This was indicated when cell 23 showed evidence of a high-rate of discharge between the time it was taken off float charge and the start of the second stage seismic testing (Appendix $C$ provides the details). The high rate of discharge resulted in cell 23 starting the second stage testing as a "failed" cell (capacity less than 80\%).

\subsection{Posttest Disassembly and Evaluation}

\section{Grid (Plate) Growth}

As reported by Ontario Hydro staff in Appendices $A$ and $B$. initial inspection showed that the positive plate packs of most cells were slightly bowed with two cells having severely bowed outer plates. Also observed were small, intermittent gaps between the positive plates and the separators and 3 to $5 \mathrm{~mm}$ of sediment in the bottom of the cells. Upon disassembly, the separators and retainers were found to be intact, but the positive plates were slightly expanded due to growth of the lead grids during service.

\section{Internal Failure Modes}

Four of the tested cells $(10,15,35$, and 57) were disassembled and inspected for internal damage. In general, the negative 
and positive plates were in poor condition. The material in the negative plates was cracked and blistered while the positive plate material was hard and compressed. The positive plates also experienced considerable loss of active material. The blisters were hollow and their position near the top of the plates suggests that they may have been the result of gas emissions from the electrolyte within the active material as a result of an excessive charging voltage.

No cracks were seen in the positive and negative terminals. And there were no cracks attributable to seismic testing observed in any of the negative or positive bus bars. There was, however. evidence of chemical attack of the positive bus bar material along casting imperfections. The corrosion actually was quite extensive, because when the positive posts of two cells were hammered to expose the interior of the positive bus bars, the cross-sections available for conduction averaged only a little over $50 \%$ of original. The rest of the bus bar had been reduced to lead oxide through chemical attack by the electrolyte.

In sumary, the postseismic capacity test results for the disassembled cells are consistent with the metallurgical observations made of the positive plates and buses. The positive plate material of cell 57 ( 918 capacity) was cracked primarily at the plate extremities. while the material in cells 35 and 15 (both 73\% capacity) was cracked extensively. Cell 10 (66\% capacity) had lost large areas of positive plate material. The positive bus material of cell 57 did not break during hammering, while that of cells 35 and 10 did break.

\subsection{CONCLUS IONS AND RECOMMENDATIONS}

The tests and analyses can be summarized as follows (from Appendix A):

1. The 10-year old Exide FHC-19 cells that were the subject of this study showed signs of age-related degradation. Some of these signs (plate warping and sedimentation) could be observed from the outside of the cells, while other indications (corrosion damage and brittleness) were discovered when the cells were dissected after the shaker tests.

2. All of the cells that were tested on the shaker table delivered uninterrupted power during repeated strong shaking. There was. however, significant loss of electrical capacity. Four of the six cells failed to deliver $80 \%$ of their rated capacity (the normal acceptance level for emergency power supply batteries) after being shaken to a 
ZPA level of about $1.5 \mathrm{~g}$. Two cells were shaken to a higher level (ZPA approximately $2 \mathrm{~g}$ ) and both showed a considerable (and additional) loss of capacity.

3. Internal components of all of the cells that were disassembled had various types of age-related damage, including corrosion. plate swelling, cracking and blistering. The amount of sediment present was uncharacteristically large for lead-calcium alloy cells.

4. There were no signs of damage to the jars during any of the tests. This includes tests where the cells were free to move in the test frame (and hence would be subject to impact loads) and tests with multicell racks.

As a result of the second stage seismic testing (with ZPAs of $2 \mathrm{~g})$. Appendix C contains two conclusions that supplement the four above:

1. FHC-19 cell 23...showed evidence of a high rate of selfdischarge as a result of previous (stage 1) seismic testing to ZPAs of $1.5 \mathrm{~g}$.

2. Although naturally aged FHC-19...cells may provide acceptable power at 1.75 VPC or more during repeated and violent shaking, and also demonstrate adequate capacity immediately following a series of seismic events. damage sustained during seismic events may cause excessively high selfdischarge and/or prevent cell recharging.

A recommendation made in Appendix $C$ by the Ontario Hydro staff states:

Cells currently under test as part of contract number 96-9358 "Sandia Battery Test Program - Accelerated Aging" should undergo duplicate discharge tests after seismic testing to evaluate cell charge acceptance. After the duplicate tests. the specific gravities of the cells should be monitored for 2 weeks while the cells are disconnected from a charging source to determine the rate of cell selfdischarge.

Sandia stafe concurs with the ontario Hydro conclusions and recommendations. Concern is expressed over the apparent dichotomy of no electrical failure during exposure to seismic events but failure of a high percentage of the same cells to provide at least $80 \%$ postseismic capacity. Questions remain regarding: 1) the validity of a test of an aged cell which shows it to be "good" based upon its voltage or capacity prior 
to a seismic event: 2) the capability of seismically exposed batteries/celis to provide postseismic emergency power: 3 ) the apparent rapid self-discharge of cells after exposure to a seismic event: 4) and the acceptance of using plate/grid growth as an indicator of accelerated aging for qualifying batteries. These questions will be examined as sandia continues this seismic research program.

\subsection{REFERENCES}

1. L. L. Bonzon and D. B. Hente. Test Series 1: SeismicFragility Tests of Naturally-Aged Class lE Gould NCX-2250 Battery Cel1s. SAND84-1737, NUREG/CR-3923, Sandia National Laboratories. Albuquerque. New Mexico, September 1984.

2. LER 75-4. Turkey Point-4. "Cracked and Buckled Plates," Event date: October 13. 1974. Report date: October 23, 1984 .

3. LER 77-55. Fitzpatrick-1. "Cracked Battery Cell Case," Event date: October 20, 1977. Report date: November 14, 1977.

4. LER 79-59. Fitzpatrick-1. "Cracked Battery Cell Case," Event date: September 4. 1979. Report date: October 2, 1979.

5. LER 81-42, Browns Ferry-1, "Cracked Cell," Event date: July 22, 1981, Report date: August 14, 1981.

6. LER 82-7. Indian Point-2, "Battery Inoperable Due to Cracked Cel1," Event date: February 2, 1982, Report date: March 19. 1982 .

7. LER 82-16. Indian Point-2, "Battery Cell Cracks," Event date: April 23, 1982, Report date: May 24, 1982.

8. LER 82-6, Connecticut Yankee, "Cracked Emergency DC Battery Cells," Event date: September 19, 1982, Report date:

October 5, 1982 .

9. Eric W. Weiss, Possible Generic Battery Problem. Memo for R. William Mills. Chief, Events Analysis Branch, Office of Inspection and Enforcement, Nuclear Regulatory Commission. November 26,1982 . 
10. IE Information Notice No. 83-11. Possible Seismic Vulnerability of Old Lead Storage Batteries, Office of Inspection and Enforcement, Nuclear Regulatory Commission. Washington. D.C.. March 14. 1983 .

11. L. L. Bonzon, et al.. "An Overview of Equipment survivability studies at Sandia National Laboratories (SNL)." SAND83-0759C, Proceedings of the ANS/ENS International Meeting on Light Water Reactor Severe Accident Evaluation. Cambridge, Massachusetts. August 28 - September 1, 1983.

12. Ltr, L. L. Bonzon, SNL, to william Farmer, NRC, subject: "Test Plan to Evaluate Nuclear Station Class IE Battery Aging Methodologies." dtd June 20, 1984

13. Ltr, L. L. Bonzon, SNL, to William Farmer, NRC, subject: "Test Plan for seismic Testing of Naturaliy-Aged Nuclearstation stationary Battery Cells." dtd June 12, 1984. 
APPENDIX A

\section{Simulated Earthquake Testing of Naturally Aged Exide FHC-19 Station Battery Cells}
J. D. Tulk
D. A. Black
W. J. Janis
C. J. Royce

Ontario Hydro Research Division 
Blank Page 


\title{
A. ontario hydro
}

\author{
SIMULATED EARTHQUAKE TESTING OF NATURALLY AGED \\ EXIDE FHC-19 STATION BATTERY CELLS \\ J.D. Tulk, Mechanical Research Department \\ D.A. Black, Mechanical Research Department \\ J.R. Janis, Chemical Research Department \\ C.J. Royce, Electrical Design Department
}

A sample of 10-year-old lead-acid storage batteries from the Calvert Cliffs Nuclear Power Station (Baltimore Gas \& Electric Company) were tested on a shaker table. Six cells were subjected to simulated earthquakes with a ZPA of approximately $1.5 \mathrm{~g}$. None of the six cells tested showed a significant drop in voltage during the shaker tests. However, only two cells could deliver $80 \%$ of their rated capacity following the seismic tests. Two cells were shaken to higher intensities ( $\mathrm{PAA}$ approximately equal to $2 \mathrm{~g})$. These cells again provided uninterrupted power during the shaker tests, but had post-seismic capacities that were below the required level for Class IE battery cells. Four cells were disassembled and examined after the shaker tests. Bus bar material from the positive side of the cells was corroded and brittle (although not cracked) and active material on the positive plates was hard and cracked. Loss of active material from the positive plates is suspected as the main cause of the reduced capacity of the cells.

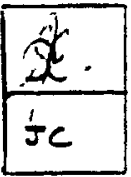

\begin{tabular}{|l|l|l|l|l|}
\hline fob $740621-108-450$ & file & 825.92 & Mare & 85-51 no. \\
\hline
\end{tabular}




\section{TABLE OF CONTENTS}

\section{$\underline{\text { Page }}$}

1.0 INTRODUCTION

1

2.0 TEST METHODS AND RESULTS 3

2.1 Initial Inspection and Conditioning 3

2.2 Seismic Testing - Single Cells 3

2.3 Jar Fragility Test 4

2.4 Multi-Cell Rack Test 5

2.5 Post-Seismic Capacity Tests and Inspection 5

3.0 CONCLUSIONS 6

4.0 ACKNOWLEDGEMENTS $\quad 7$

$\begin{array}{ll}\text { REFERENCES } & 8\end{array}$

TABLES 99

$\begin{array}{ll}\text { FIGURES } & 12\end{array}$

$\begin{array}{ll}\text { APPENDIX A } & 34\end{array}$ 
To Mr. B.A. Oliver

Manager

Electrical Design Department

Design \& Development Division

\author{
SIMULATED EARTHQUAKE TESTING OF NATURALLY AGED \\ EXIDE FHC-19 STATION BATTERY CELLS
}

J.D. Tulk, Mechanical Research Department

D.A. Black, Mechanical Research Department

J.R. Janis, Chemical Research Department

C.J. Royce, Chemical Research Department

A sample of 10-year-old lead-acid storage batteries from the Calvert Cliffs Nuclear Power Station (Baltimore Gas \& Electric Company) were tested on a shaker table. Six cells were subjected to simulated earthquakes with a $Z P A$ of approximately $1.5 \mathrm{~g}$. None of the six cells tested showed a significant drop in voltage during the shaker tests. However, only two cells could deliver $80 \%$ of their. rated capacity following the seismic tests. Two cells were shaken to higher intensities (ZPA approximately equal to $2 \mathrm{~g}$ ). These cells again provided uninterrupted power during the shaker tests, but had post-seismic capacities that were below the required level for Class IE battery cells. Four cells were disassembled and examined after the shaker tests. Bus bar material from the positive side of the cells was corroded and brittle (although not cracked) and active material on the positive plates was hard and cracked. Loss of active material from the positive plates is suspected as the main cause of the reduced capacity of the cells.

\title{
1.0 INTRODUCTION
}

The large lead-acid storage battery cells that are the subject of this report are used to provide DC power for nuclear power stations under emergency conditions. It is well known that these cells deteriorate with age and it is normal practice to test them at regular intervals to ensure that they are capable

\begin{tabular}{|c|c|c|c|c|c|}
\hline$\sqrt{10}$ & $740621-108-450$ & file & 825.92 & date March 13, 1985 & $\begin{array}{l}\text { roport no. } \\
85-51-K\end{array}$ \\
\hline
\end{tabular}


of meeting a specified level of performance. What is not so well understood however, is the effect of age on the mechanical fragility of the cells and whether older cells would be capable of surviving seismic events at the operating basis earthquake (OBE) or safe shutdown earthquake (SSE) levels and to continue to meet the load profile required by the Class IE system. Because of the importance of storage batteries to the class IE system, the US Nuclear Regulatory Commission has requested Sandia National Laboratories (SNL) to evaluate the impact of aging and seismic exposure on battery capacity. Ontario Hydro has been sub-contracted to carry out capacity and seismic shaker tests on naturally aged cells supplied by SNL from several US nuclear power stations (SNL Contract 47-4077). The program addresses possible variations between designs produced by different manufacturers.

This report describes the results of a series of experiments carried out at the Ontario Hydro Research Laboratories on a set of ten (10) year old Exide FHC-19 cells from the Calvert Cliffs Nuclear Power Station (Baltimore Gas and Electric Company). The shaker tests were carried out in two stages, with the first stage tests simulating earthquakes with zero-period acceleration levels (ZPA) of about $1.5 \mathrm{~g}$ and the second stage tests reaching $\mathrm{ZPA}$ levels of about $2 \mathrm{~g}$. During the first stage tests, the cells delivered uninterrupted power. However, the discharge tests that followed the shaker tests showed that only two of the six cells could deliver more than 808 of their rated power. During the second stage (high intensity) shaker tests, two cells were tested and both showed a major loss of capacity. To determine the nature of the deterioration of the internal components of the cells, several cells were disassembled for inspection and metallurgical examination. It was found that the active material on the positive plates was hardened and, in many instances, cracked, and that a significant volume of this material had fallen out of the plate grid. Corrosion and brittleness was also noted in the positive bus material.

This report summarizes the tests and results for this batch of cells. A more detailed discussion of the tests and results is contained in references 1,2 (battery condition and performance), 3 and 4 (seismic test results).

The tests described here were part of a larger program of testing of aged cells. Other cell types tested to date have included Gould FKR (Pickering Nuclear Generating Station) $/ 5,6,7 /$, Gould NCX2250 (J.A. Fitzpatrick Nuclear Power Station)/8/. Exide EMP-13 (Shippingport Nuclear Power Station/9/ and C\&D LCU-13 (North Anna NPS) $/ 10 \%$. 


\subsection{TEST METHODS AND RESULTS}

\subsection{Initial Inspection and Conditioning}

Ten Exide FHC-19 cells were received from the Calvert Cliffs plant. Except for a small crack on the top plate of one cell, no external damage was found. On the negative plates, regular horizontal and vertical cracks were observed in the sponge lead active material. Small hollow blisters were found near the tops of these plates. The positive plates were bowed (severely in two cells). There was 3 to $5 \mathrm{~mm}$ of sediment in the bottoms of the cells, principally lead oxide, but with pockets of lead sulphate. The cells were conditioned (charged and discharged several times to stabilize their condition) and tested for capacity. The electrical state of the cells prior to the seismic tests is summarized in Table 1.

\subsection{Seismic Testing - Single Cells}

The shaker table and instrumentation used in these experiments is described in Reference 3. The table provides independent motion in three directions. The motion is based on a quasirandom signal, filtered to match the frequency content of a typical earthquake. The duration of each test was 30 seconds. The seismic test method was based on the recommendations of IEEE Std 344-1975 and IEEE std 501-1978:

For the single cell seismic tests, the cells were mounted individually on the shaker table in a stiff frame, designed to minimize relative motion between the cell jar and the table (see Figure 1). These tests were intended to investigate possible failure modes of internal components. The rig was designed to minimize the danger of jar failure and acid spill. Accelerometers were mounted on the base of the frame and on the top of one of the posts of the cell.

During the seismic tests, the cells were discharged against a resistive load at a $1 \mathrm{~h}$ discharge rate. They were considered to have "passed" a seismic test if they remained above $1.75 \mathrm{~V}$ during and immediately after the test. The cells were shaken at progressively higher levels up to the machine limit. Each of the four cells that were tested in the single cell frame passed all of the tests. Table 2 provides a log of the test sequence, while Table 3 summarizes the results. There were no sudden drops in cell voltage during any of the shaker tests.

Seismic test results are presented in this report and in References 3 and 4 in terms of acceleration response spectra of the table motion. To provide a convenient means of comparing the acceleration levels encountered during various tests, each test 
spectrum is compared to a normalized spectrum defined in IEEE std 501-1978/11/. The shape of this spectrum is intended to reflect the frequency content of the "typical" seismic environment for electrical equipment. The intensity of the simulated seismic motion is expressed in terms of the ZPA (zero period acceleration) which provides a conservative lower-bound estimate of the peak acceleration of the base.

The single cell tests were conducted in two stages. In the first stage, the shaker table controllers were tuned so that the frequency content of the table motion fitted the standard spectrum shape specified in IEEE Std 501-1978. These tests were carried out in July 1984. Response spectra computed from the base accelerometer outputs are shown in Figures 3 through 14. For the second phase, the controllers were re-adjusted to provide a higher overall level of shaking. These tests took place in December 1984 and involved two cells - \#23 which had previously taken part in a rack test, and \#51 which had been tested in the single cell frame in July. Spectra from the second phase are shown in Figures 15 through 20.

The higher ' $g$ ' levels for the second stage tests were achieved largely by increasing the intensity of mid to high frequency components of the shaker motion (ie. above $5 \mathrm{~Hz}$ ). The result is a spectrum shape that is rather higher than the standard IEEE 501 shape over the high frequency range. If such.a spectrum is compared to the standard shape strictly according to the IEEE 501 methodology, then the ZPA of the fitted spectrum will be a very conservative estimate of the peak accelerations that the cell actually experienced. In this context, it must be recognized that the IEEE Standard is intended to provide a basis for the seismic qualification of a broad range of electrical equipment. The purpose of the experiments described here, however, is not to qualify the cells, but to explore the types of damage that might be inflicted in earthquake motion. Thus, we believe that we are justified in departing from the strict letter of the standard so that the $\mathrm{ZPA}$ values quoted in our results are reasonably close to the peak accelerations encountered during the tests. (See Appendix A for a more complete discussion.) To provide meaningful $\mathrm{ZPA}$ data, we have fitted an alternative set of normalized spectra to the experimental data over the $4 \mathrm{~Hz}$ to $33 \mathrm{~Hz}$ range. These alternative spectra are shown on Figures 15 through 20 as double lines.

\subsection{Jar Fragility Test}

Earlier testing (Gould NCX2250 cells from J.A. Fitzpatrick Nuclear Power Station/8/) had shown that cracks in the jars would propagate more readily if the cell was mounted loosely in 
the test frame. A single test was carried out with an FHC-19 cell loosely mounted in the frame. In this case, the cell jar had no sign of prior cracking and no damage occurred as a result of the test.

\subsection{Multi-Cell Rack Test}

The single-cell tests were designed to focus on failure modes of internal components. To examine the possible failure modes that would be encountered with normal in-plant mounting arrangements, a shaker test was carried out on a set of three cells mounted on a rack that resembled typical seismically qualified battery racks (see Figure 2). The test $\mathrm{log}$ and results are shown on Tables 2 and 3 , while test spectra are shown in Figures 21 and 22. No failures occurred during the rack tests.

For practical reasons, the rack that was used for these tests held only three cells. Full scale racks in generating stations are typically much longer. The present tests could be nonconservative, since long strings of cells could, under shaking, impose large impact loads on cells at the end of the string. These tests provide no positive indication that this is a potential source of trouble. Nevertheless, we suggest that in severe seismic environments, it would be beneficial to separate cells into groups of three or so, with rigid partitions on the rack and flexible electrical connections between groups.

\subsection{Post-Seismic Capacity Tests and Inspection}

Following the shaker table tests the cells were re-tested for electrical capacity. The results of these tests are shown on Table 1. For the first stage tests ( $\mathrm{ZPA}$ around $1.5 \mathrm{~g}$ ), there was some loss of discharge capacity for all cells. Only two of the cells had capacities, as measured from the start of the seismic test series, that met the acceptance criterion of more than 808 rated capacity. For the second stage ( $\mathrm{ZPA}$ around $2 \mathrm{~g}$ ), the cells both provided uninterrupted power during the seismic tests, but had post-test capacities that were less than 808 of the rated capacity.

For the first stage seismic tests, the capacity tests were done within a few days of the shaker tests. In this case, the test capacity reflected the charge that remained in the cells after the shaking. However, the capacity tests that followed the second stage (higher intensity) seismic tests were delayed for approximately four weeks. Because of our experience with self discharge of aged, seismically damaged cells, we believed that the charge remaining in the cells after this extended wait could be significantly lower than the charge that was available immediately following the shaker test. Accordingly, these two cells were re-charged before the final capacity test. We do not 
know at this point how the extra discharge-charge cycle would effect the measured capacity.

Following the seismic tests, four of the cells were disassembled and inspected. Internal components showed various types of age-related damage, including corrosion (bus bars and plates), cracking (positive and negative plates), hardening and loss of active material (positive plates) and gas blistering (negative plates). The degree of damage noted during the post-test inspection correlated with the drop in capacity that occurred because of the simulated seismic shaking.

\subsection{CONCLUSIONS}

1. The ten year old Exide FHC-19 cells that were the subject of this study showed signs of age related degradation. Some of these signs (plate warping and sedimentation) could be observed from the outside of the cells, while other indications (corrosion damage and brittleness) were discovered when the cells were dissected after the shaker tests.

2. All of the cells that were tested on the shaker table delivered uninterrupted power during repeated strong shaking. There was however significant loss of electrical capacity. Four of the six cells failed to deliver $80 \%$ of their rated capacity (the normal acceptance level for emergency power supply batteries) after being shaken to a ZPA level of about $1.5 \mathrm{~g}$. Two cells were shaken to a higher level (ZPA approximately $2 \mathrm{~g})$ and both showed a considerable loss of capacity.

3. Internal components of all of the cells that were disassembled had various types of age related damage, including corrosion, plate swelling, cracking and blistering. The amount of sediment present was uncharacteristically large for lead-calcium alloy cells.

4. There were no signs of damage to the jars during any of the tests. This includes test where a cell was free to move in the test frame (and hence would be subject to impact loads) and tests with multi-cell racks. 


\subsection{ACKNOWLEDGEMENTS}

Test cells and funding for this project were provided by Sandia National Laboratories. This support is gratefully acknowledged. Lloyd Bonzon and Don Hente of SNL are thanked for their large contribution to the project. Within ontario Hydro, contract coordination was handled by the Electrical Design Department. We are grateful to Colin Royce and Jerry Schendel for their efforts. Much of the testing and analysis was carried out by Brian Aucoin of the Chemical Research Department and Gordon Paulsen of the Mechanical Research Department. Their able work was essential to the successful outcome of the project.

Approved by:

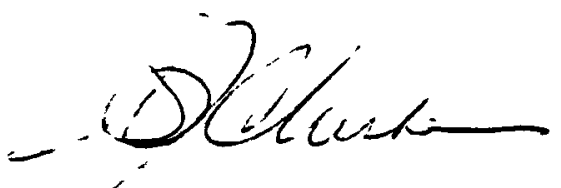

G.J. Clarke

Manager

Mechanical Research Dept $\pi$
Prepared by:

J.p. Tulk

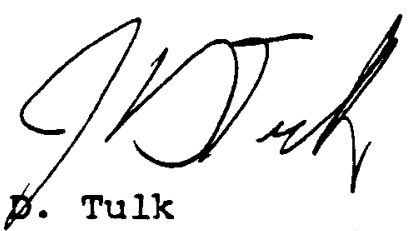

Unit Head - Special Projects

Applied Structural and Solid Mechanics section

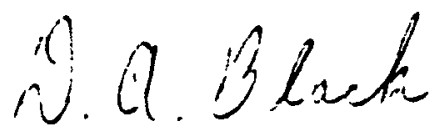

D.A. Black

Engineer

Lines, Materials \& Seismology

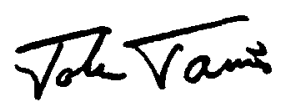

W.J. Janis

Chemist

Organic Research Section

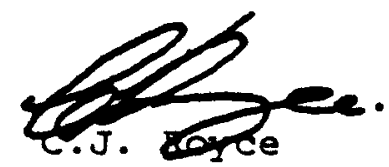

Supervising Design Engineer Studies and Analys is

Electrical Design Department

JDT/DAB/WJJ/CJR: lg/1 jh 


\section{REFERENCES}

1. W.J. Janis, "Seismic Testing of Calvert Cliffs Nuclear Power Station Batteries - Cell Inspection and Capacity Tests". Ontario Hydro Research Division Report C84-120-P.

2. W.J. Janis, "Seismic Testing of North Anna and Calvert Cliffs Nuclear Power Station Batteries - Second Stage, High Table Accelerations", Ontario Hydro Research Division Report C85-19-P.

3. D.A. Black and G.D. Paulson, "Seismic Testing of Calvert Cliffs Nuclear Power station Batteries (Exide FHC-19)". Ontario Hydro Research Division Report 84-418-P.

4. D.A. Black and G.D. Paulsen, "Seismic Retesting of Calvert Cliffs Nuclear Power Plant Batteries at Increased Accelerations", Ontario Hydro Research Division Report 85-55-P.

5. W.J. Janis, "Seismic Testing of Aged Nuclear Generating Station Batteries - Cell Inspection and Capacity Tests". Ontario Hydro Research Division Report C84-5-K.

6. G.D. Paulsen, "Seismic Qualification of Station Cells". Ontario Hydro Research Division Report B83-96-H.

7. D.A. Black and G.D. Paulsen. "Seismic Testing of Gould Cells Removed from Pickering GS in a Rack". Ontario Hydro Research Division Report B84-38-P.

8. J.D. Tulk, "D.A. Black, W.J. Janis and B.M. Kukreti, "Seismic Testing of Naturally Aged Station Battery Cells". NUREG/CR-3923 SAND 84-1737. (Also issued as Ontario Hydro Research Division Report B84-211-K).

9. J.D. Tulk, D.A. Black, W.J. Janis and B.M. Kukreti, "Seismic Testing of Naturally Aged Exide EMP-13 Station Battery Cells". Ontario Hydro Research Division Report B84-427-K.

10. J.D. Tulk, D.A. Black, W.J. Janis and B.M. Kukreti, "Seismic Testing of Naturally Aged C\&D LCU-13 Station Battery Cells". Ontario Hydro Research Division Report 84-425-K.

11. IEEE std 501-1978, "IEEE Standard, Seismic Testing of Relays", The Institute of Electrical and Electronics Engineers, Inc., 1978. 
TABLE 1

CELL CAPACITIES BEFORE AND AFTER SEISMIC TESTING

First Stage Tests - ZPA Approximately $1.5 \mathrm{~g}$

\begin{tabular}{|c|c|c|c|c|c|c|}
\hline \multirow[b]{2}{*}{ Cell } & \multicolumn{3}{|c|}{ 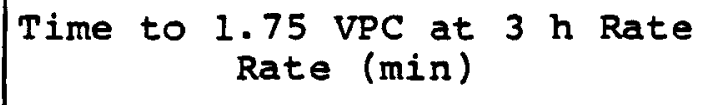 } & \multicolumn{3}{|c|}{$\begin{array}{c}\text { Per Cent of Rated Capacity } \\
\text { at } 3 \mathrm{~h} \text { Rate }\end{array}$} \\
\hline & $\begin{array}{l}\text { Pre- } \\
\text { Seismic }\end{array}$ & $\begin{array}{l}\text { Post- } \\
\text { Seismic* }\end{array}$ & $\begin{array}{c}\text { Post-Seismic } \\
\text { Plus } \\
\text { Seismic** }\end{array}$ & $\begin{array}{c}\text { Pre- } \\
\text { Seismic }\end{array}$ & $\begin{array}{c}\text { Post } \\
\text { Seismic* }\end{array}$ & $\begin{array}{c}\text { Post-Seismic } \\
\text { Plus } \\
\text { Seismic** }\end{array}$ \\
\hline $\begin{array}{l}10 \\
15 \\
23 \\
35 \\
51 \\
57\end{array}$ & $\begin{array}{l}180 \\
155 \\
155 \\
155 \\
170 \\
180\end{array}$ & $\begin{array}{l}104 \\
104 \\
121 \\
121 \\
162 \\
149\end{array}$ & $\begin{array}{l}118 \\
131 \\
135 \\
132 \\
177 \\
164\end{array}$ & $\begin{array}{r}100 \\
86 \\
86 \\
86 \\
94 \\
100\end{array}$ & $\begin{array}{l}58 \\
58 \\
67 \\
67 \\
90 \\
83\end{array}$ & $\begin{array}{l}66 \\
73 \\
75 \\
75 \\
98 \\
91\end{array}$ \\
\hline AVG & 166 & 127 & 143 & 92 & 71 & 80 \\
\hline
\end{tabular}

Second Stage Tests - ZPA Approximately 29

\begin{tabular}{|c|c|c|c|c|}
\hline \multirow[b]{2}{*}{ Cell } & \multicolumn{2}{|c|}{$\begin{array}{c}\text { Time to } 1.75 \text { VPC at } 3 \mathrm{~h} \text { Rate } \\
\text { Rate (min) }\end{array}$} & \multicolumn{2}{|c|}{$\begin{array}{c}\text { Per Cent of Rated Capacity } \\
\text { at } 3 \mathrm{~h} \text { Rate }\end{array}$} \\
\hline & $\begin{array}{l}\text { Pre- } \\
\text { Seismic }\end{array}$ & $\begin{array}{l}\text { Post- } \\
\text { Seismic*** }\end{array}$ & $\begin{array}{l}\text { Pre- } \\
\text { Seismic }\end{array}$ & $\begin{array}{l}\text { Post } \\
\text { Seismic*** }\end{array}$ \\
\hline $\begin{array}{l}23 \\
51\end{array}$ & $\begin{array}{l}135 \\
176\end{array}$ & $\begin{array}{l}60 \\
95\end{array}$ & $\begin{array}{l}75 \\
98\end{array}$ & $\begin{array}{l}33 \\
53\end{array}$ \\
\hline AVG & 155 & 78 & 86 & 43 \\
\hline
\end{tabular}

* Cells not recharged following seismic testing.

* Capacity during seismic test at 1 h rate converted to $3 \mathrm{~h}$ capacity and added to post-seismic capacity, as discussed in Reference 1.

***Cells re-charged following second stage seismic tests. 
TABLE 2

TEST HISTORY - CALVERT CLIFFS NPP - EXIDE - MODEL FHC-19 CELLS

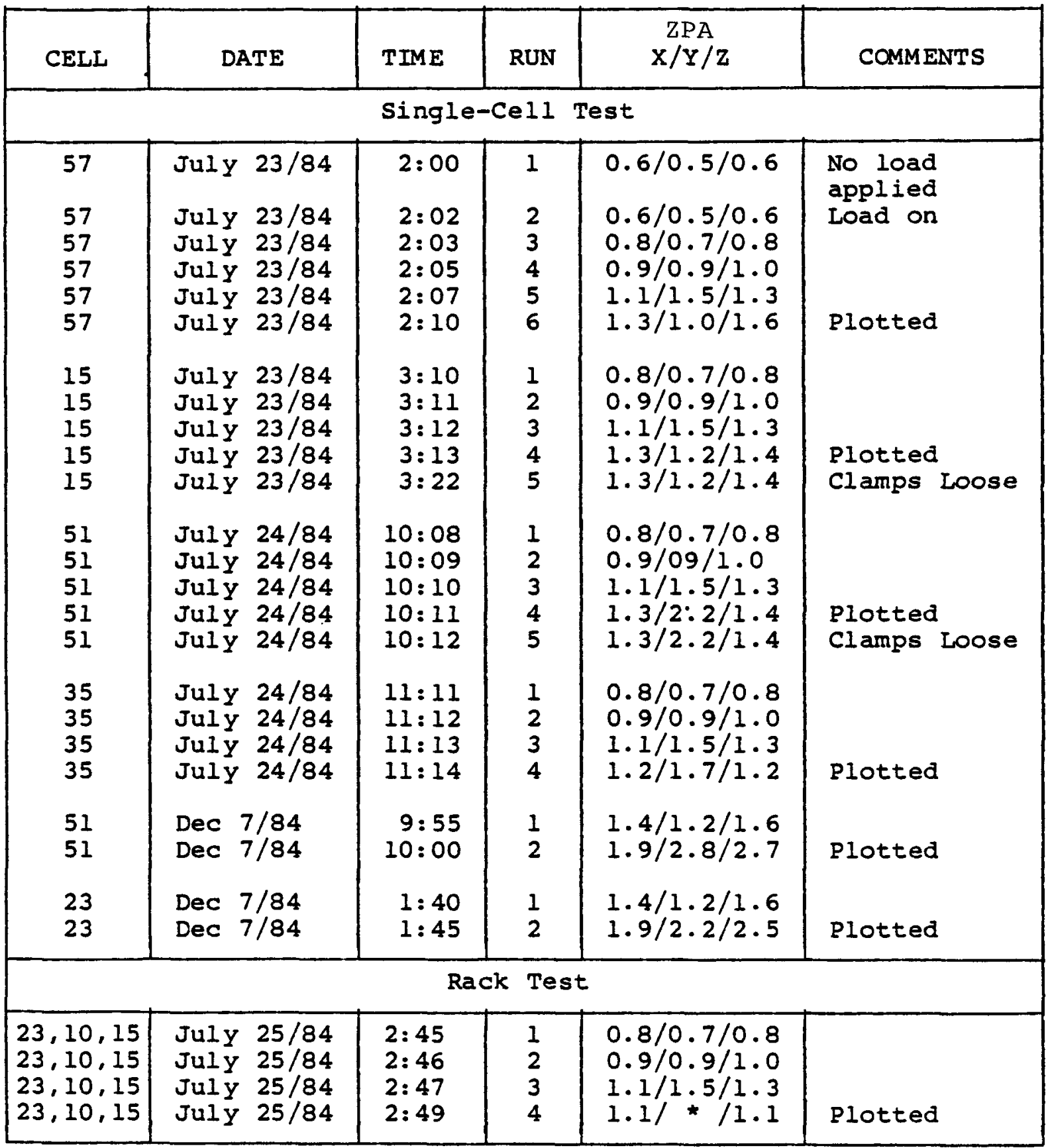

*Signal Distorted - No Reliable Data Available 
TABLE 3

SEISMIC TEST RESULTS

\begin{tabular}{|c|c|c|c|}
\hline CELL NUMBER & DIRECTION & $\mathrm{ZPA}$ & FIGURE \\
\hline \multicolumn{4}{|c|}{ Single-Cell Tests - First Stage } \\
\hline $\begin{array}{l}57 \\
57 \\
57\end{array}$ & $\begin{array}{l}X \\
Y \\
Z\end{array}$ & $\begin{array}{l}1.31 \\
0.98 \\
1.59\end{array}$ & $\begin{array}{l}3 \\
4 \\
5\end{array}$ \\
\hline $\begin{array}{l}15 \\
15 \\
15\end{array}$ & $\begin{array}{l}X \\
Y \\
Z\end{array}$ & $\begin{array}{l}1.26 \\
1.15 \\
1.40\end{array}$ & $\begin{array}{l}6 \\
7 \\
8\end{array}$ \\
\hline $\begin{array}{l}51 \\
51 \\
51\end{array}$ & $\begin{array}{l}X \\
Y \\
Z\end{array}$ & $\begin{array}{l}1.29 \\
2.24 \\
1.40\end{array}$ & $\begin{array}{r}9 \\
10 \\
11\end{array}$ \\
\hline $\begin{array}{l}35 \\
35 \\
35\end{array}$ & $\begin{array}{l}X \\
Y \\
Z\end{array}$ & $\begin{array}{l}1.21 \\
1.71 \\
1.22\end{array}$ & $\begin{array}{l}12 \\
13 \\
14\end{array}$ \\
\hline \multicolumn{4}{|c|}{ Single-Cell Tests - Second Stage } \\
\hline $\begin{array}{l}51 \\
51 \\
51\end{array}$ & $\begin{array}{l}\mathbf{Y} \\
\mathbf{Z} \\
\mathrm{X}\end{array}$ & $\begin{array}{l}1.9 \\
2.8 \\
2.7\end{array}$ & $\begin{array}{l}15 \\
16 \\
17\end{array}$ \\
\hline $\begin{array}{l}23 \\
23 \\
23\end{array}$ & $\begin{array}{l}X \\
Y \\
Z\end{array}$ & $\begin{array}{l}1.9 \\
2.2 \\
2.5\end{array}$ & $\begin{array}{l}18 \\
19 \\
20\end{array}$ \\
\hline \multicolumn{4}{|c|}{ Rack Tests } \\
\hline $\begin{array}{l}15,23,10 \\
15,23,10 \\
15,23,10\end{array}$ & $\begin{array}{l}\mathrm{X} \\
\mathrm{Y} \\
\mathbf{Z}\end{array}$ & $\begin{array}{c}1.13 \\
\text { Signal Lost } \\
1.13\end{array}$ & $\begin{array}{l}21 \\
22\end{array}$ \\
\hline
\end{tabular}




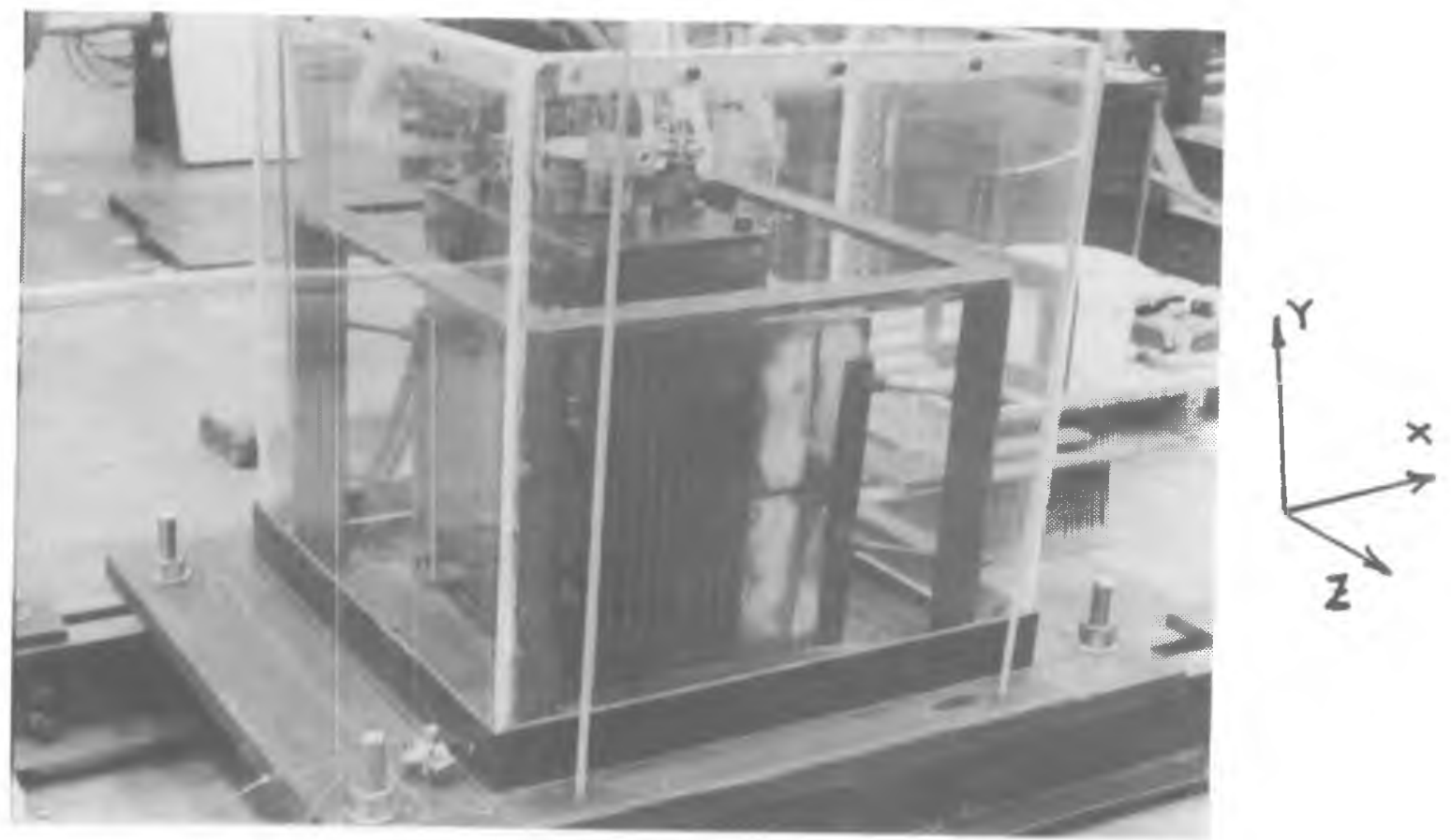

Figure 1

Typical mounting of an Exide FHC-19 cell in single-cell frame. Cell is clamped at four corners with threaded rods. Accelerometers are mounted on the base and on one of the terminal posts. Axes of vibration are indicated. 


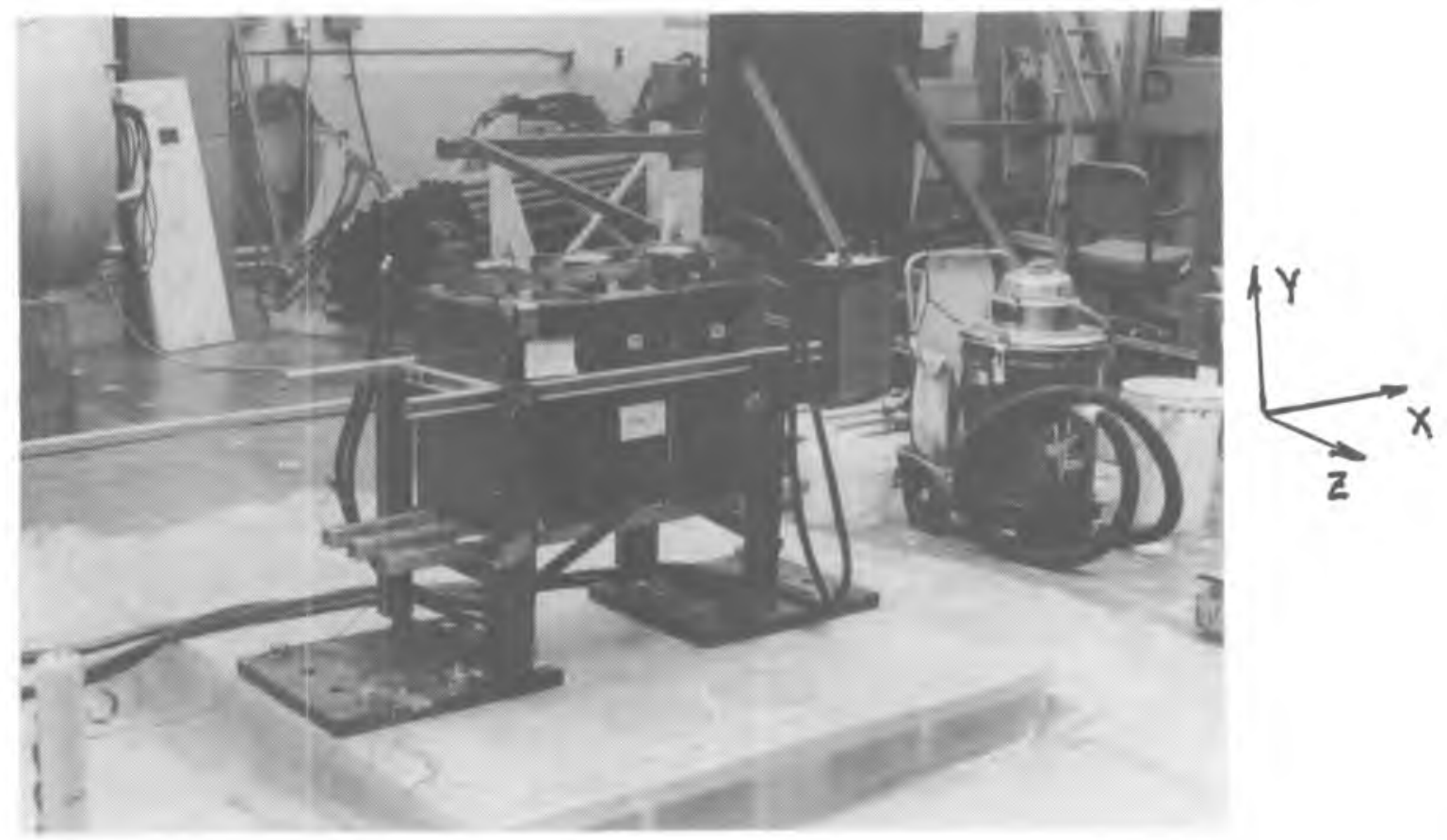

Figure 2

Mounting of Exide EHC-19 cells in multi-cell rack. Axes of vibration are indicated. 


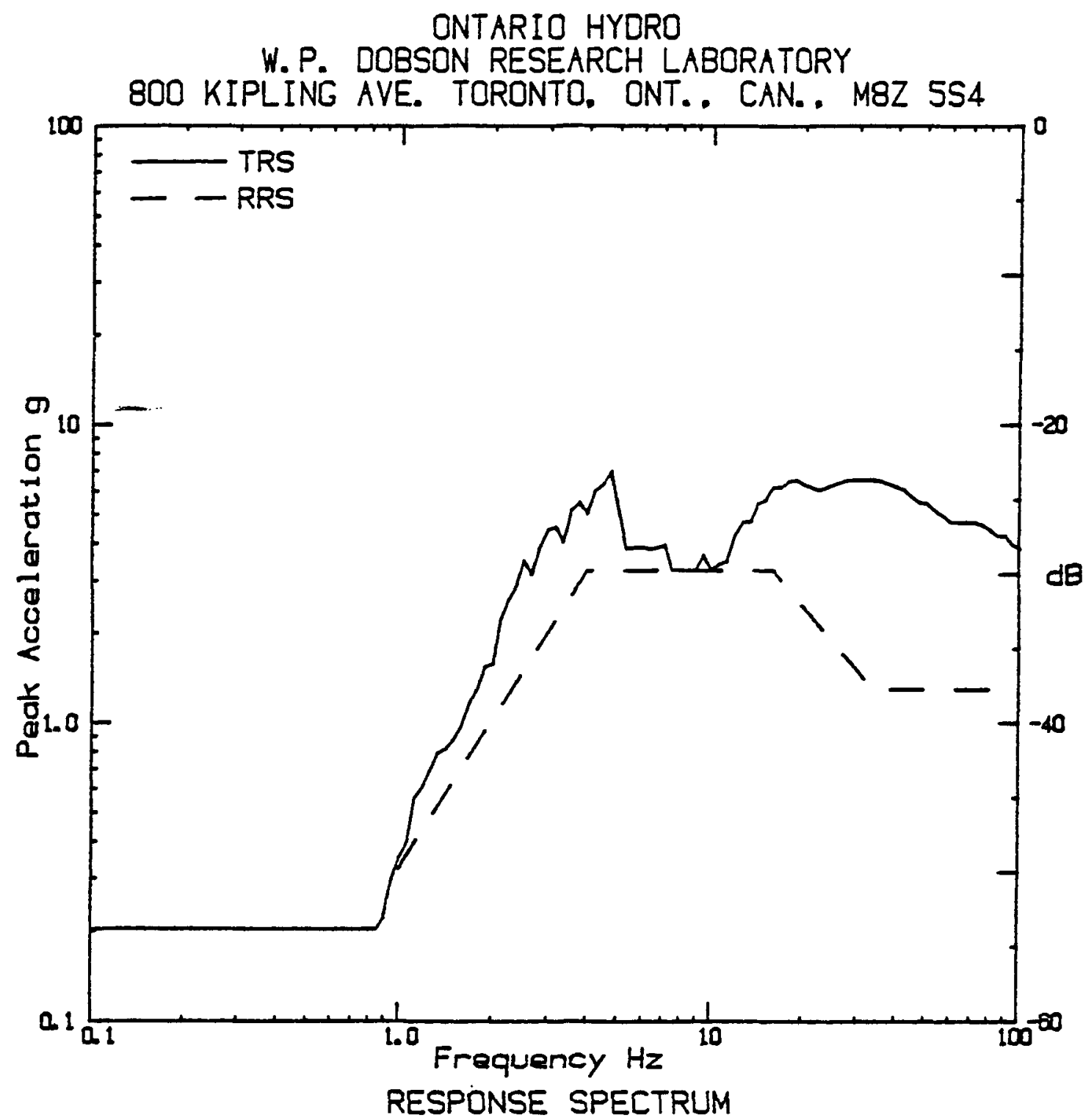

FIGURE 3

TEST ITEM

Stotion call. Exide Modal FHC-19, Serial 57, Calvart Cliffs N.P.P.

PARTICULARS

July 23/84. Time 2313. Temp ('C) 23. Humidity(z) 53. Prass (kPa) 100.2. Groph 5200

SPECIFICATIONS

Specs IEEE 501. Conditions operating. 3 hour rate ispan 7

ANALYSIS

Type Maximax, Demping (z) 5 , B. $W_{0}=1 / 12$ Detoves, Axis $X_{0}$ Shaker tri-axiol. $Z P A=1.31 \mathrm{~g}$

ACCELEROMETER

Wilcoxon Serial S771. Range dB49, Location bose-mounting plate. Channel I 


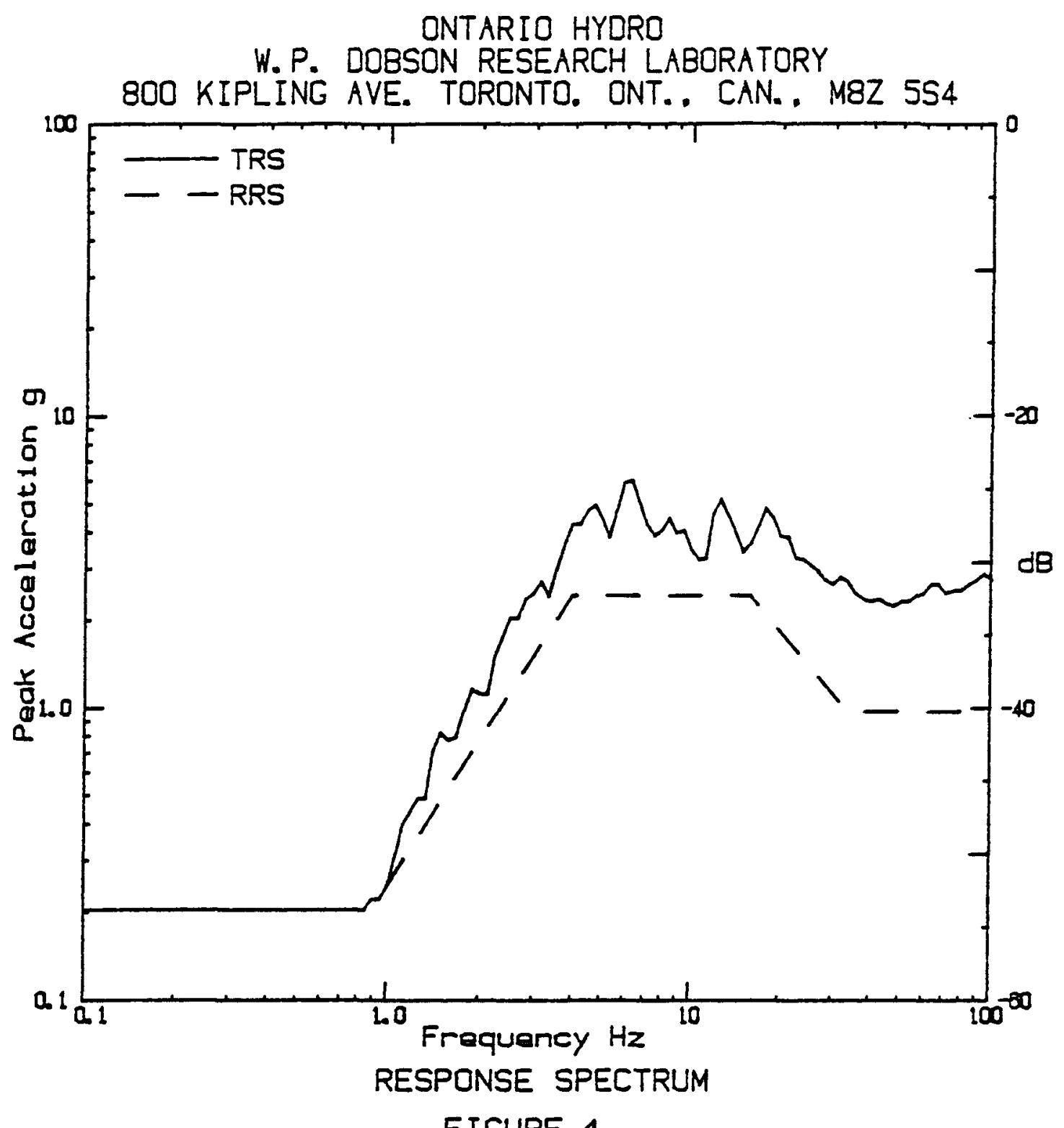

FIGURE 4

TEST ITEM

Station cell. Exide, Model FHC-19. Sarial 57. Calvart Cliffs N.P.P.

PARTICULARS

July 23/84. Time 23 13. Temp ('C) 23. Humidity(x) 53. Press (KPa) 100.2. Graph 5201

SPECIFICATIONS

Specs IEEE 501. Conditions operating. 3 hour rate : span 7

ANALYSIS

Type Maximax. Domping (I) 5, B. W. $=1 / 12$ Dctoves. Axis Y. Shaker tri-axial. ZPX $=.98 \mathrm{~g}$

ACCELEROMETER

Wilcoxon Sarial S761. Range d849. Location bose-mounting plate. Channel 2 


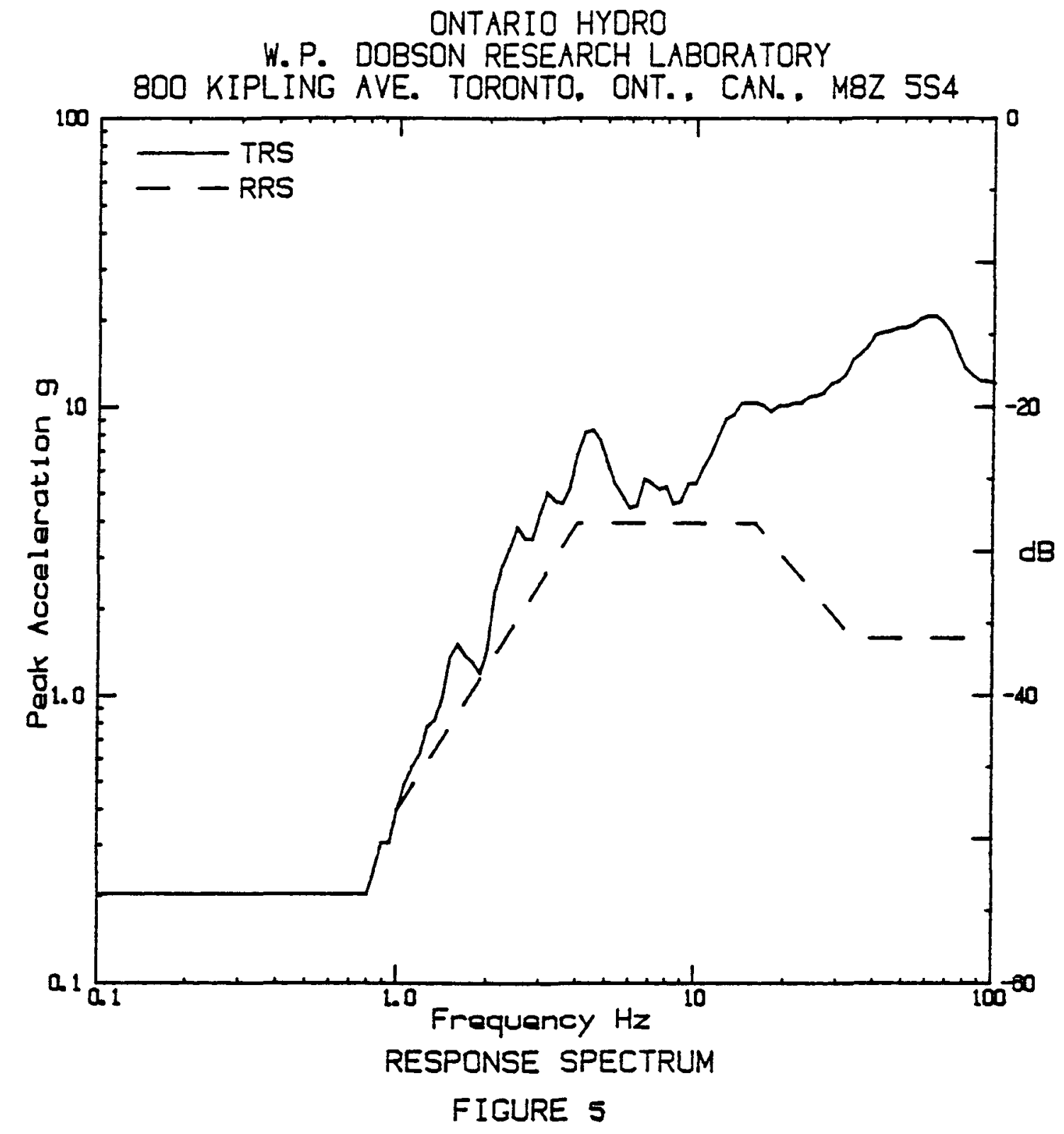

TEST ITEM

Station call. Exida. Modal FHC-19. Serial 57. Calvart Cliffs N.P.P.

PARTICULARS

July 23/84, Tima 2: 13. Tamp('C) 23. Humidity(Z) 53. Press (kPa) 100.2. Graph 5202

SPECIFICATIONS

Specs IEEE 501. Conditions operating, 3 hour rate : span 7

ANALYSIS

Type Maximax. Damping (X) $5_{0}$ E. W. $=1 / 12$ Dctaves, Axis Z. Shaker tri-axial. ZPX $=1.599$

ACCELEROMETER

Wilcoxon. Serial S297. Range d849. Location base-mounting plate. Channel 3 


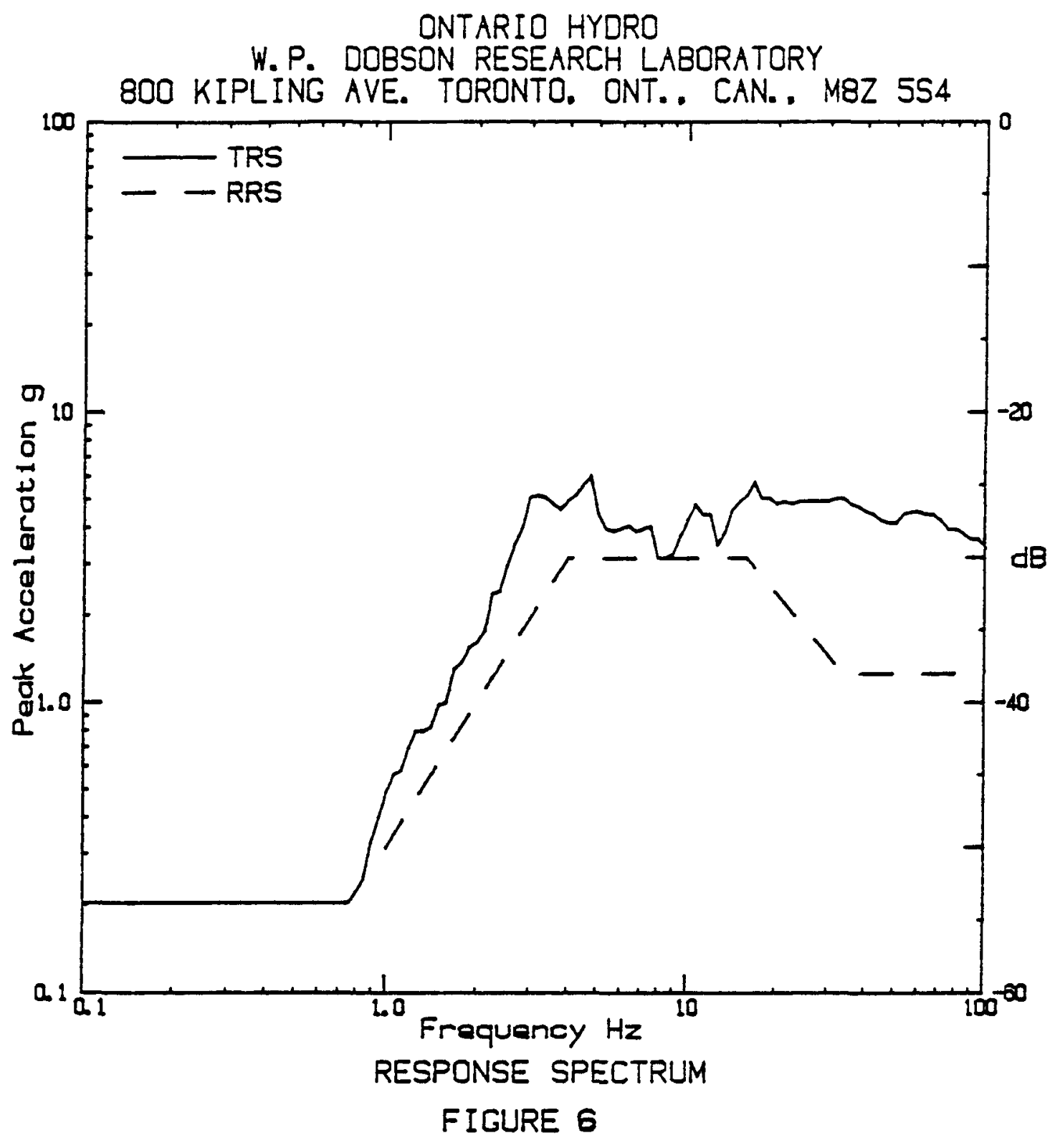

TEST ITEM

Station call. Exida. Modal FHC-19. Sarial 15. Calvert Cliffs N.P.P.

PARTICULARS

July 23/84, Time 23 45. Temp('C) 23. Humidity(z) 53. Press (kPa) 100. 2. Graph 5206

SPECIFICATIONS

Specs IEEE 501. Conditions operating: 3 hour rate, spen 7

ANALYSIS

Type Maximax, Damping (J) 5. B. $W_{0}=1 / 12$ Octaves, Axis $X_{0}$ Shaker tri-axial. ZPX $=1$. 26g

ACCELEROMETER Wilcoxono Serial 5771. Range dB49. Locotion bose-mounting plate.

$$
\text { A-17- }
$$




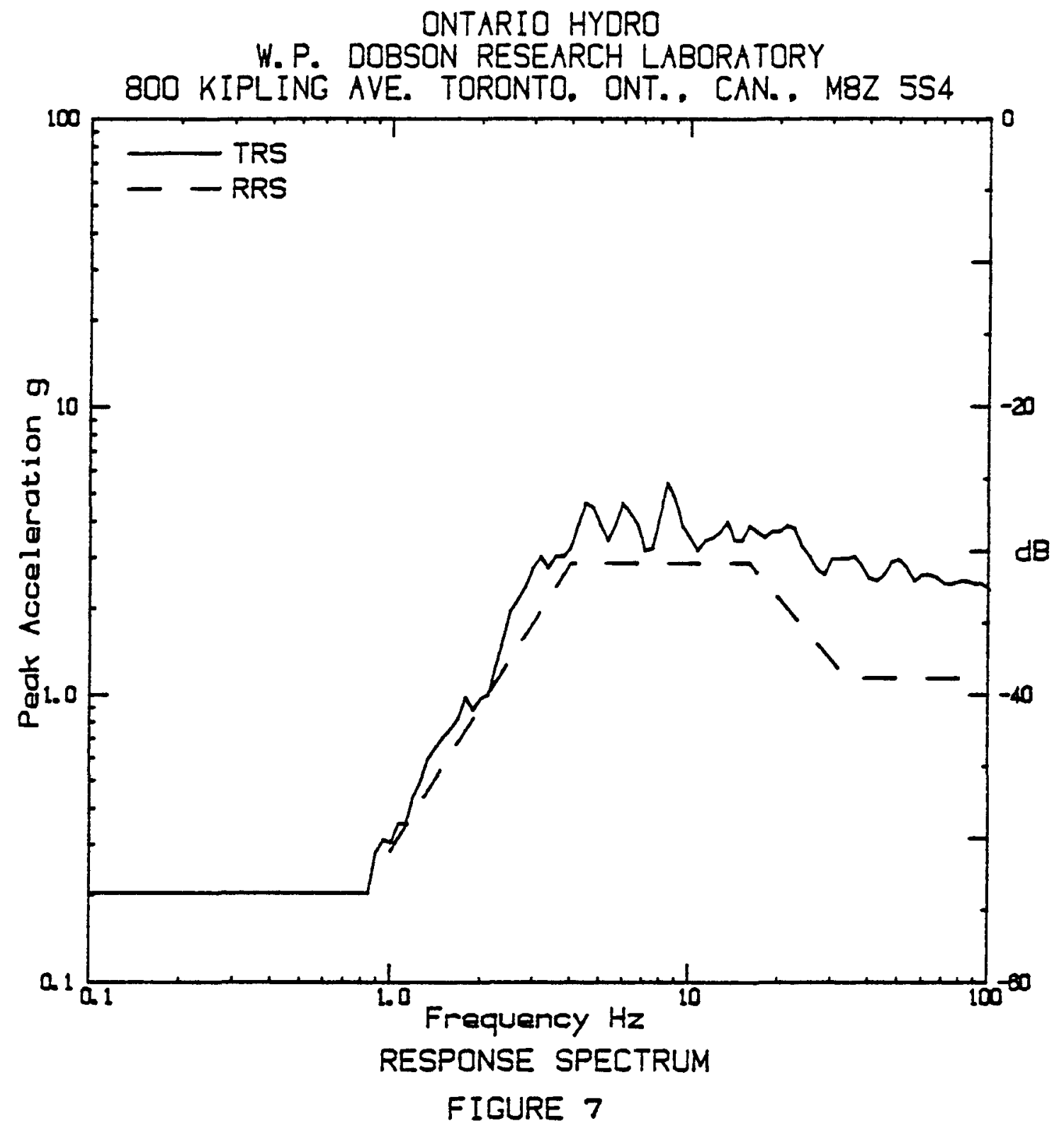

TEST ITEM

Station call. Exide. Model FHC-19. Serial 15. Colvert Cliffs N.P.P.

PARTICULARS

July 23/84. Time 2: 45. Temp('C) 23. Humidity( $(z)$ 53. Prass (kPa) 100. 2.

Graph 5207

SPECIFICATIONS

Specs IEEE 501. Conditions operating i 3 hour rate. spon 7

ANALYSIS

Type Maximax. Damping (z) 5. B. $W_{0}=1 / 12$ Dctaves. Axis $Y$. Shaker tri-OXial. $Z P X=1.15 g$

ACCELEROMETER

Wilcoxon. Serial S761. Range d849. Location bose-mounting plote.
Channel 2

$$
\text { A-18- }
$$$$
85-51
$$ 


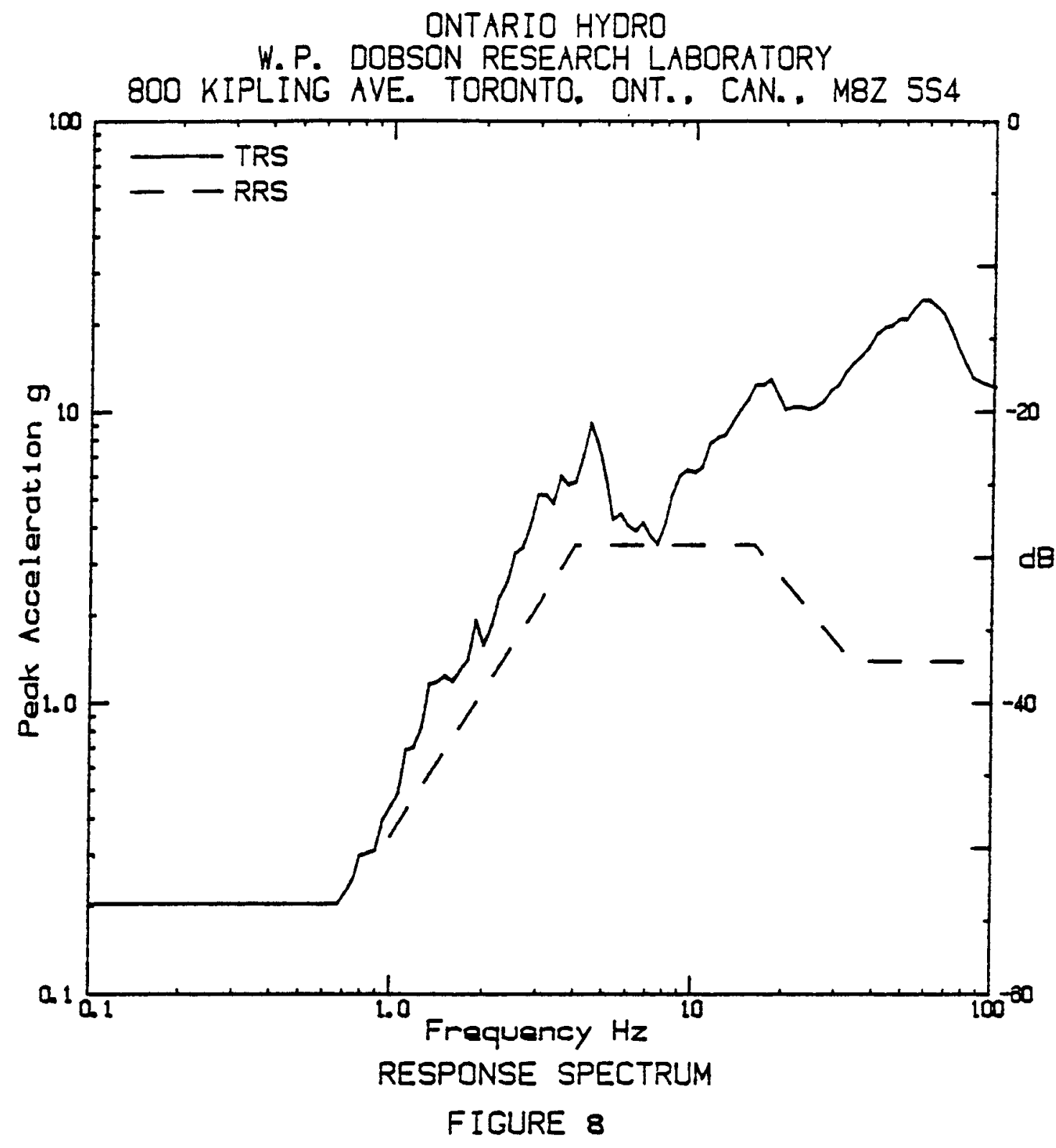

TEST ITEM

Station call. Exide, Modal FHC-19, Sorial 15. Calvart Cliffo N.P.P.

PART ICULARS

July 23/84. Time 23 45. Temp('C) 23. Humidity(Z) 53. Press (kPa) 100.2. Groph $\mathbf{5 2 0 8}$

SPECIFICATIONS

Specs IEEE 501. Conditions operating 3 hour rate, span 7

ANALYSIS

Type Maximax, Domping (Z) 5 , B. $W_{0}=1 / 12$ Octovas, Axis Z. Shaker tri-axial. ZPX $=1.4 \mathrm{~g}$

ACCELEROMETER

Wilcoxon. Serial S297. Range dB49. Locetion bose-mounting plate. Channel 3 


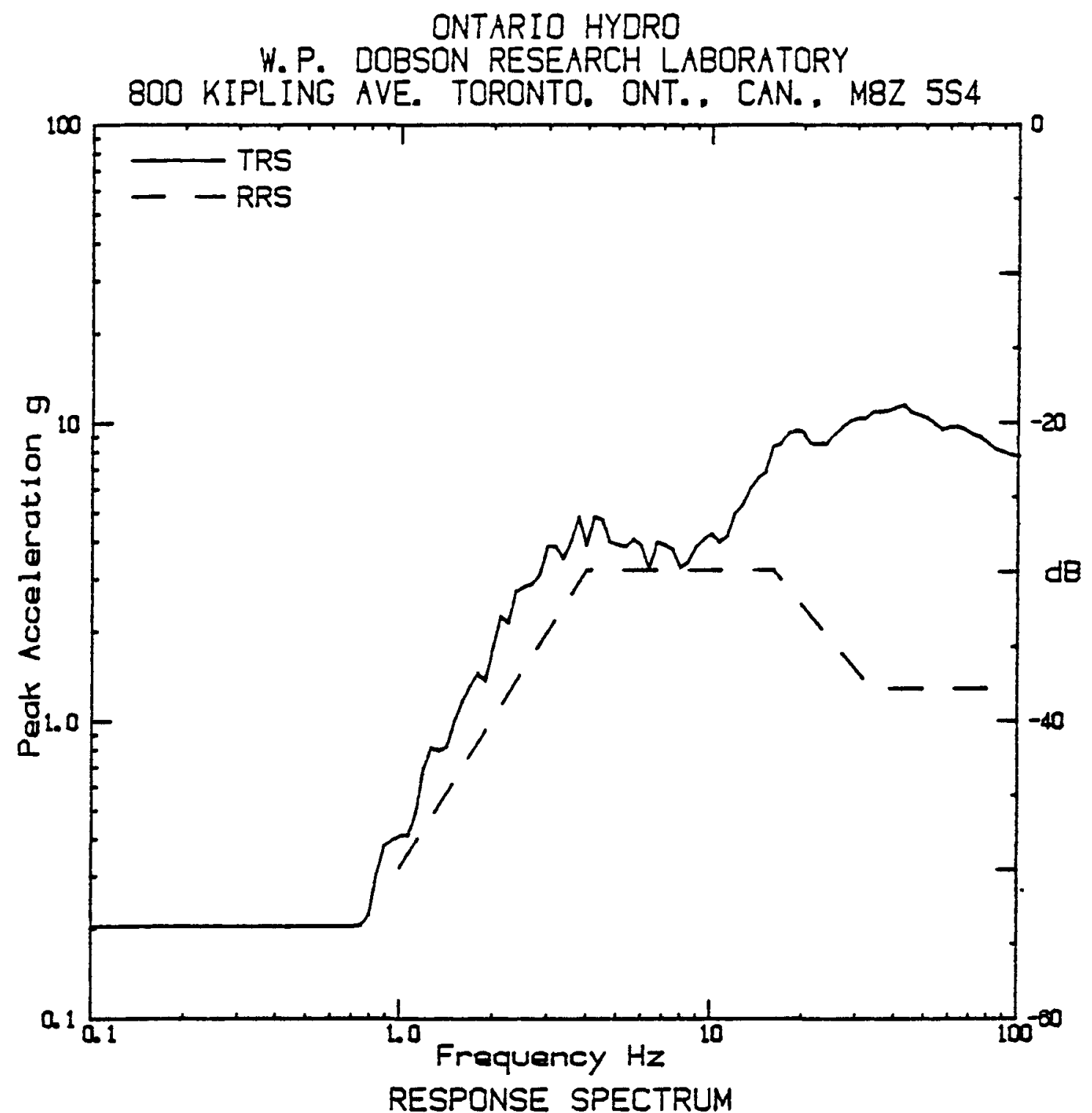

FIGURE $S$

TEST ITEM

Station call. Exide. Modal FHC-19. Serial 51. Calvart Cliffs N.P.P.

PARTICULARS

July 23/84, Time 10: 12. Temp ('C) 23. Humidity (l) 53.

Prass (kPa) 100. 2. Graph 5212

SPECIFICATIONS

Specs IEEE 501. Conditions operating , 3 hour rate, spon 7

ANALYSIS

Type Maximax. Damping (x) 5. B. W. = 1/12 Octoves. Axis X. Shaker tri-axial. $Z P A=1.29 g$

ACCELEROMETER

Wilcoxon. Serial S771. Range d849. Location base-mounting plate. Channel 1 


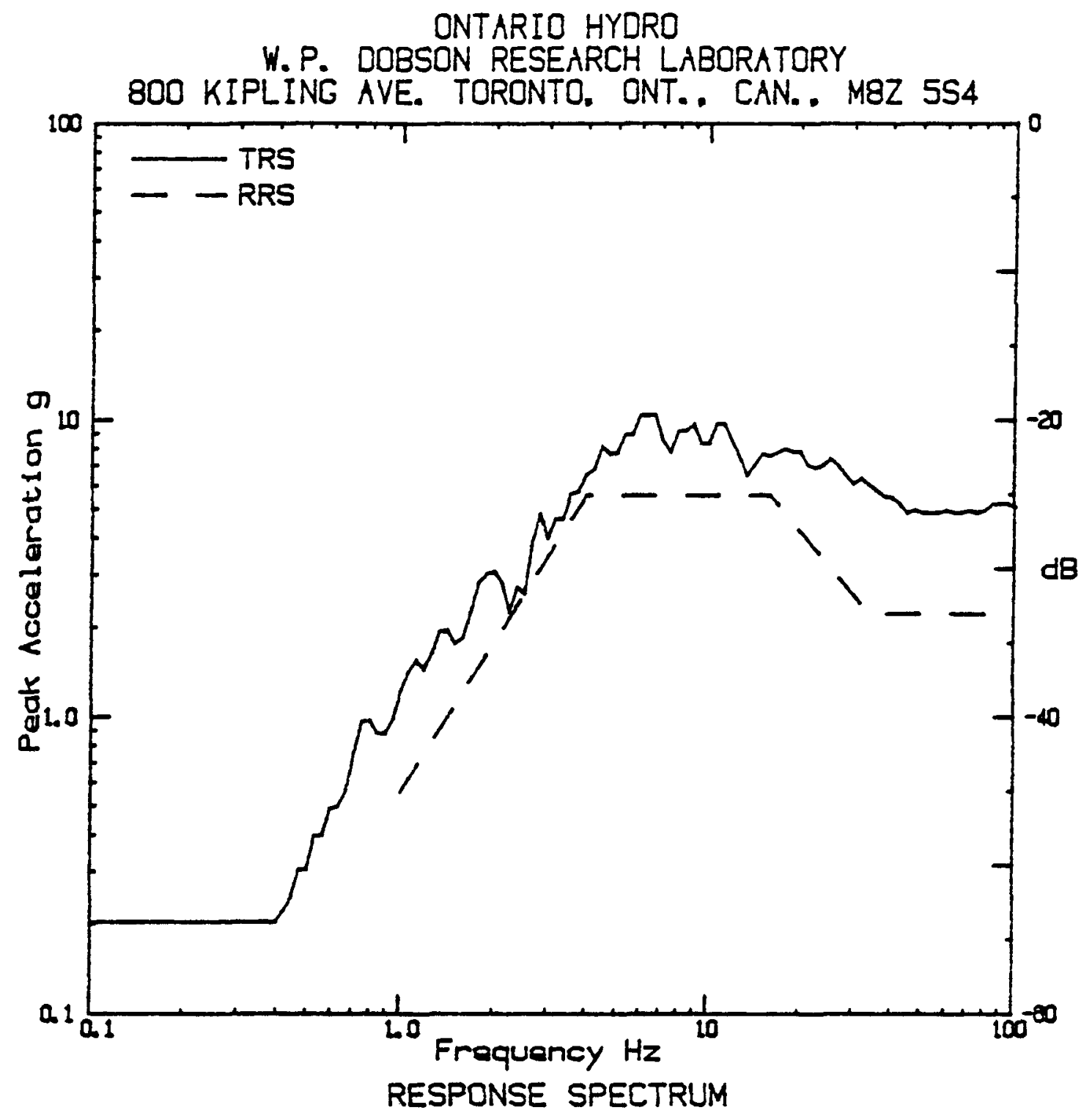

FIGURE 10

\section{TEST ITEM}

Station call. Exide Modal FHC-19. Serial 51. Calvart Cliffs N.P.P.

PARTICULARS

July 23/84, Time 10:12. Temp('C) 23. Humidity (D) 53,

Prass (kPa) 100. 2. Groph 5213

SPECIFICATIONS

Specs IEFE 501. Conditions operating : 3 hour rata span 7

ANALYSIS

Type Maximax. Damping $\cos 5, B_{0} W_{0}=1 / 12$ Octoves, Axis $Y_{0}$ Shaker tri-aXial. ZPX $=2.24 \mathrm{~g}$

ACCELERDMETER

Wilcoxon Sorial 5761. Range dB49. Location base-mounting plate 


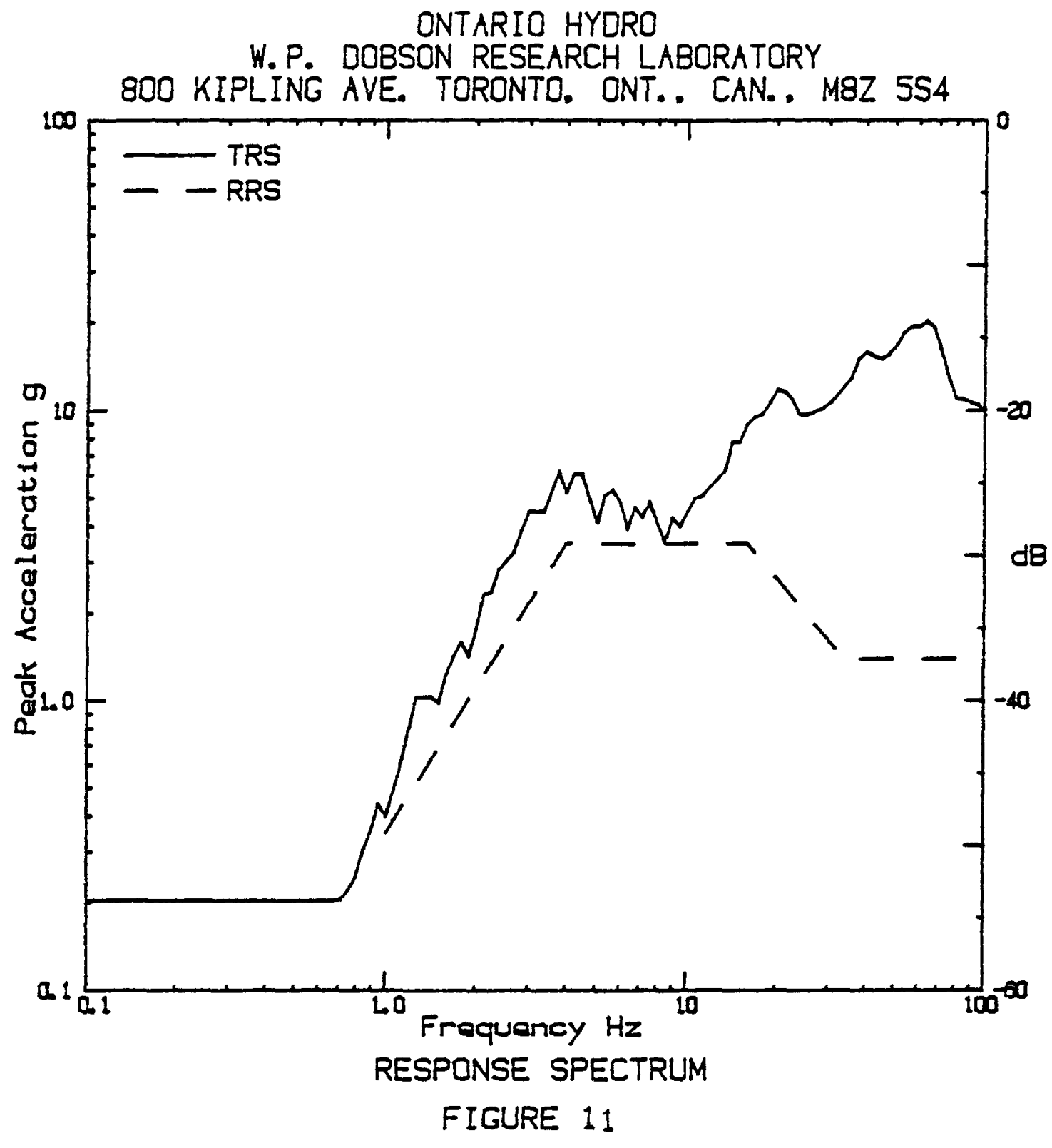

TEST ITEM

Station cell. Exide. Modal FHC-19. Sarial 51. Colvert Cliffs N.P.P.

PARTICULARS

July 23/84, Time 10:12. Tamp ('O) 23. Humidity( 53

Prass (kPa) 100. 2. Graph 5214

SPECIFICATIONS

Spece IEEE SO1. Conditions oparating 3 hour rata, spon 7

ANALYSIS

Type Maximax, Damping (D) 5, 8. $y_{0}=1 / 12$ Dotaves, Axis Z. Shakar to 1 -axial. $Z P h=1.4 g$

ACCELEROMETER

Wilcoxor, Saricl S297. Range d949, Locotion bose-mounting plote. Channel 3 


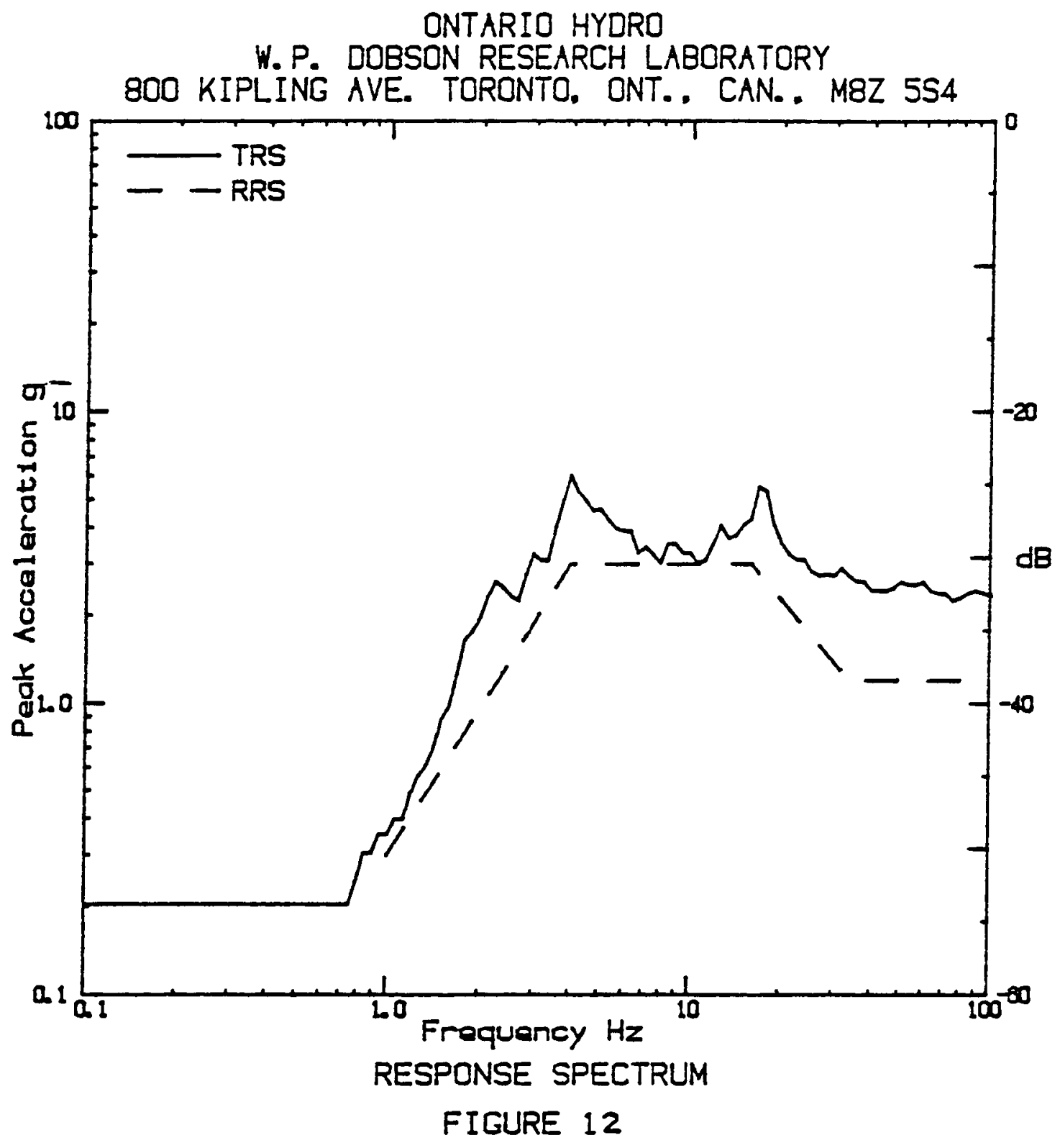

TEST ITEM

Station call. Exida, Modal FHC-19, Sarial 35, Calvart Cliffs N.P.P.

PARTICULARS

July 23/84, Time 11, 14, Tomp('C) 23. Humidity(D) 53.

Proes (xpa) 1002 . Graph 5218

SPECIFICATIONS

Spece IEEE 501. Conditions operating, 3 hour rate, spen 7

ANALYSIS

Type Maximox, Domping $\cos 5$ \&. $W_{0}=1 / 12$ Dctoves, Axis $X_{0}$ Shaker tri-Oxial. ZPX $=1.21 \mathrm{~g}$

ACCELEROMETER

Wilcoxon, Serial S771. Range dB49. Location beso-mounting plate. Channel I 


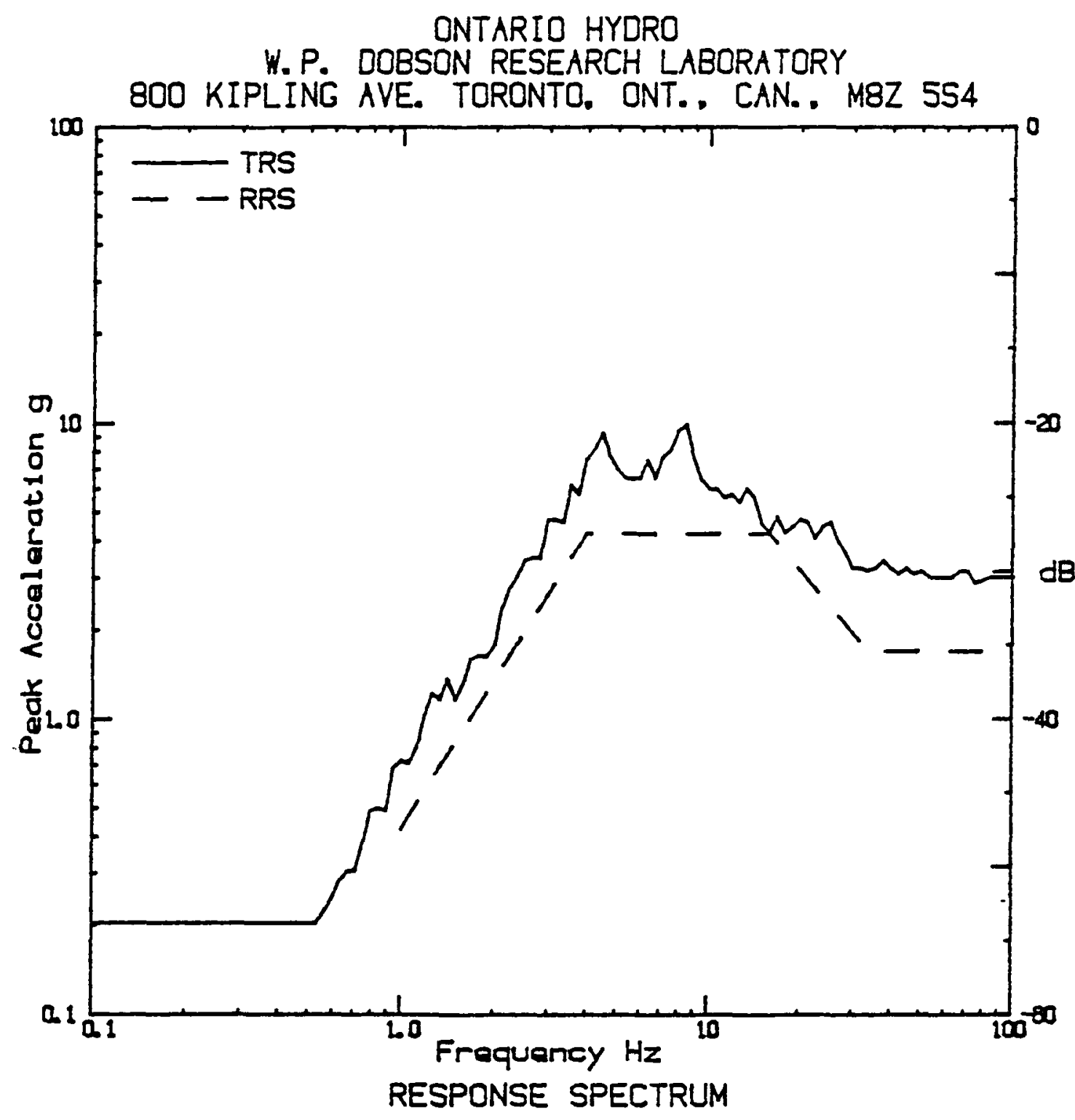

FIGURE 13

TEST ITEM

Station call. Exide Modal FHC-19, Serial 35. Colvert Cliffs M.P.P.

PARTICULARS

July 23/84, Time 11:14. Temp('O) 23. Humiditycos 53 .

Pross (kPD) 100.2. Groph 5219

SPECIFICATIDNS

Specs IEEE 501. Conditions operating: 3 hour rate. span 7

ANALYSIS

Type Maximax, Damping $\cos 5$ B. $W_{0}=1 / 12$ Dctoves, Axis Y. Shaker tri-oxial. ZPX $=1.71 \mathrm{~g}$

ACCELERDMETER

Wilcoxon Serial 5781. Range d849. Location bose-mounting plate. Channal 2 


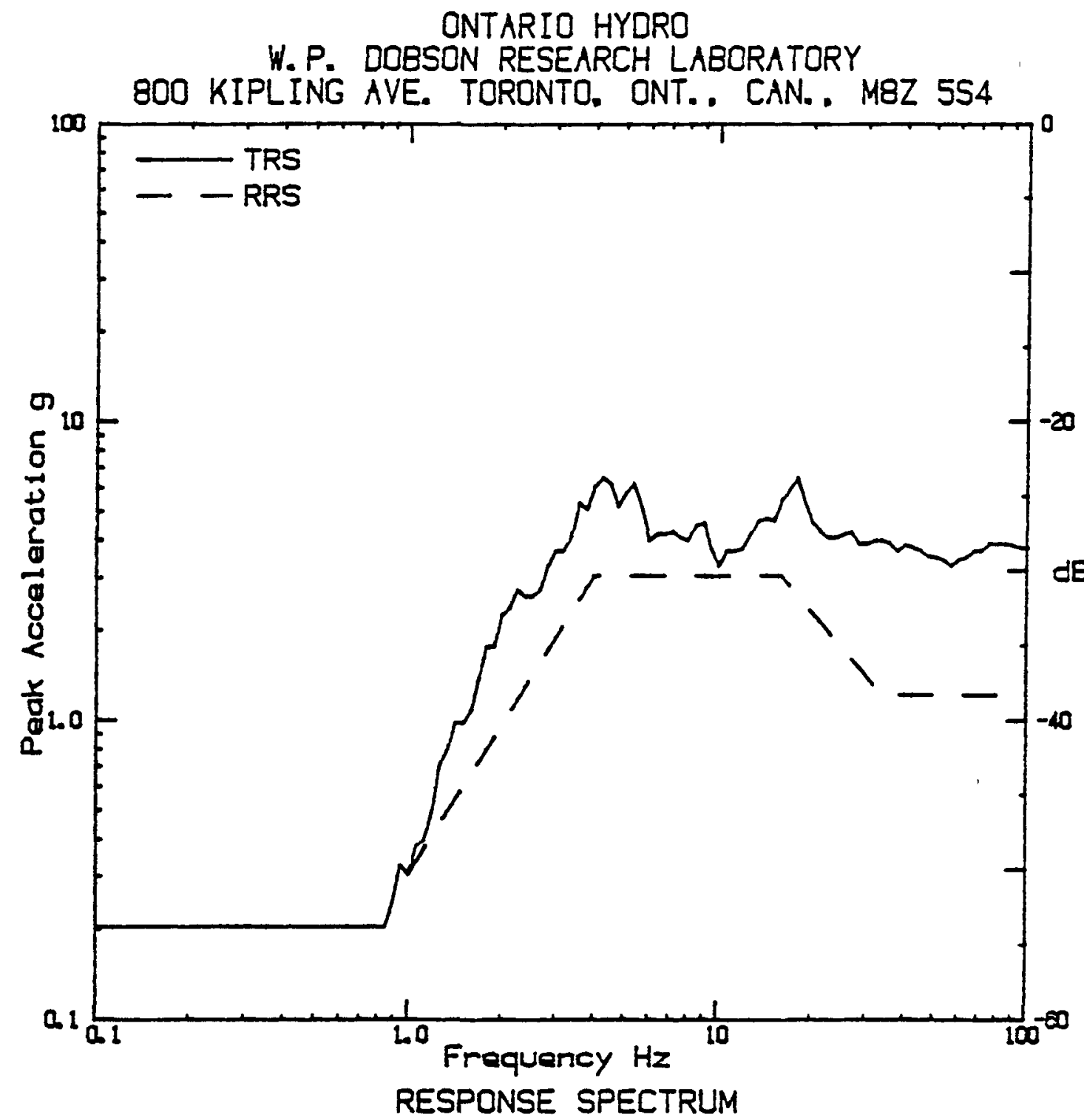

FIGURE 14

TEST ITEM

station call. Exide, Modal FHC-19, Serial 35, Colvert Cilffs N.P.P.

PARTICULARS

July 23/84. Time 11:14, Temp ('C) 23. Humidity(D) 53 .

Press CPAD ica. 2. Graph 5220

SPECIFICATIONS

Spees IEEE 501. Conditions operating a 3 hour rate, spen 7

ANALYSIS

Type Maximax. Damping (2) 5 , \& W, = 1/12 Octoves, Axis Z.

Shaker tri-oxial. $Z P X=1.22 \mathrm{~g}$

ACLELEROMETER Whannel 3 Serial S297. Renge dB49, Location bese-mounting plata. 


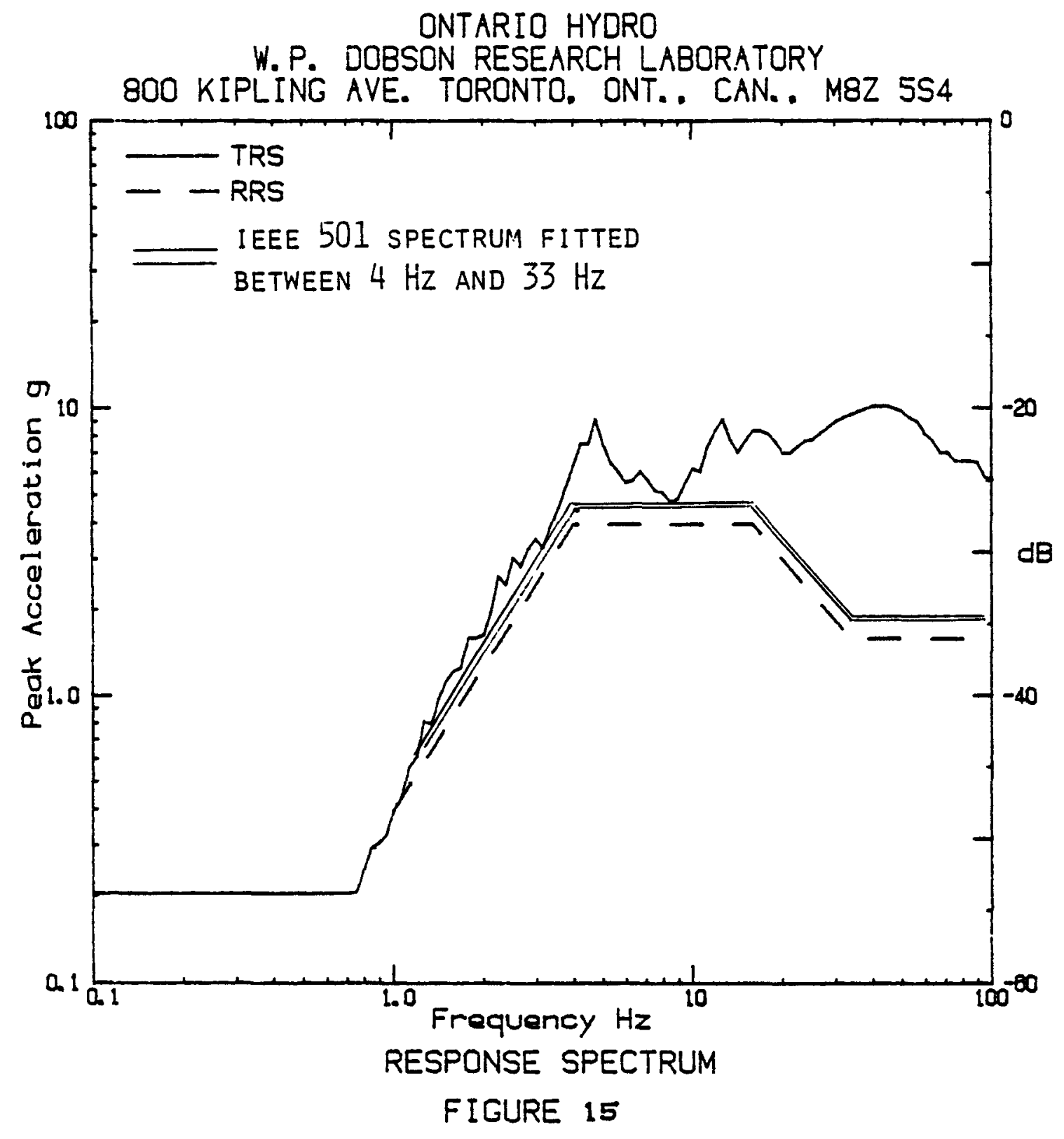

TEST ITEM

Station Call. Exida. Modal FHC 19. Call "51

PARTICULARS

Dec. 7/84. Time 10,00. Tamp('C) 24. Humidity (z) 29. Press (KPa) 100.5. Graph 5409. Record 0

SPECIFICATIONS

Specs IEEE 344, Conditions oparating, table limit

ANALYSIS

Type Maximax. Damping (Z) 5. B. W. = 1/12 Dctaves, Axis X-base. Shaker tri-aXial. ZPX $=1.9 \mathrm{~g}$

ACCELEROMETER

Wilcoxon, Serial 1214. Range d848. Location mounting plate. TT 722. Channel 1

$$
\text { A- } 26 \text { - 85-51 }
$$




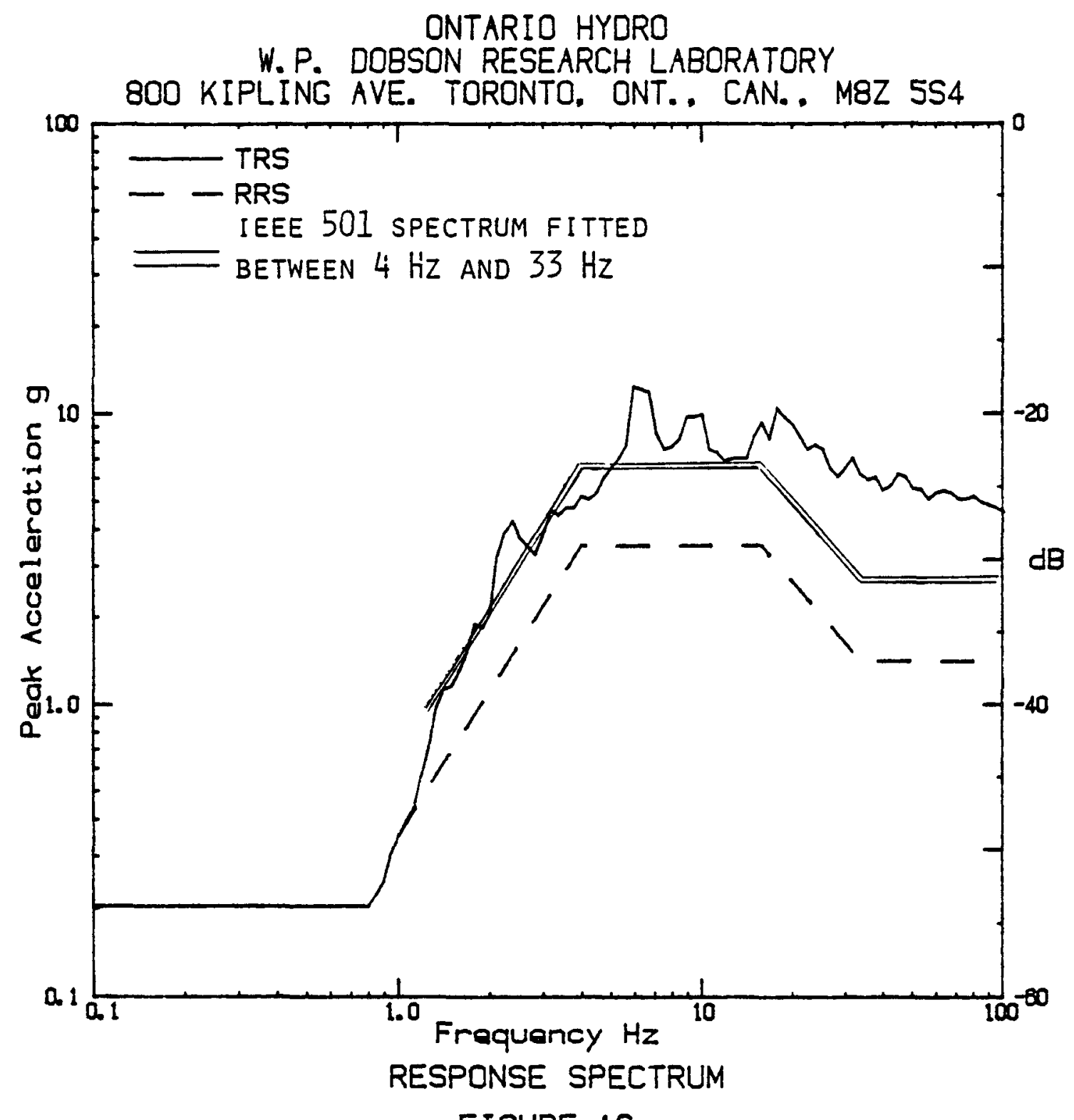

FIGURE 16

TEST ITEM

Station Call. Exide. Model FHC 19. Cell "51

PARTICULARS

Dea 7/84. Time 10: 00. Temp('C) 24. Humidity(z) 29. Press (kPa) 100.5. Graph 5410. Record 0

SPECIFICATIONS

Specs IEEE 344. Conditions operating, table limit

ANALYSIS

Type Maximax. Damping (z) 5, B. $W_{0}=1 / 12$ Octaves, Axis Y-base. Shaker tri-OXial. $Z P A=2 \cdot 8 \mathrm{~g}$

ACCELEROMETER

Wilcoxon. Serial 1215. Range d848. Location mounting plate. IT 722. Channel 2 


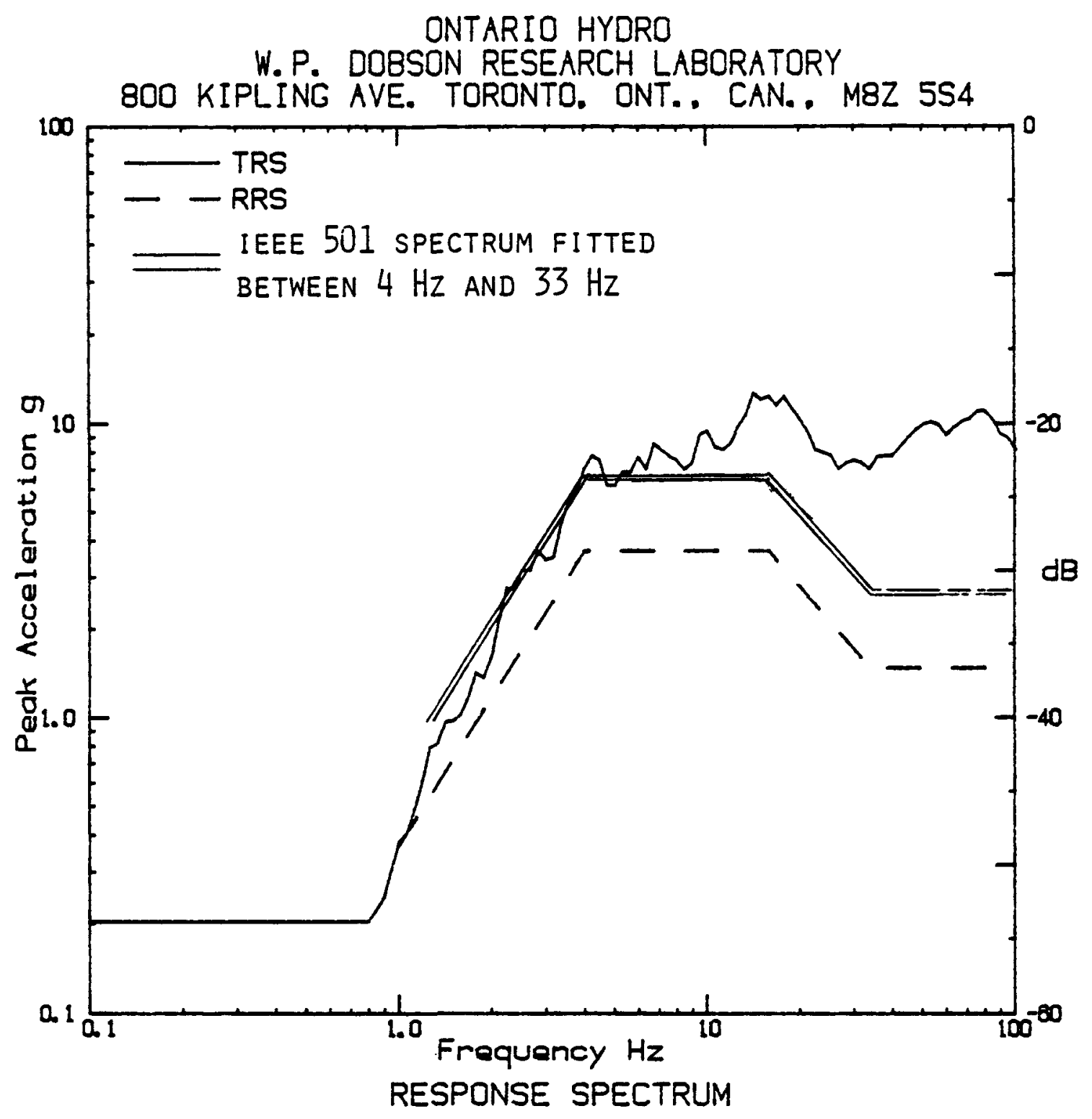

FIGURE 17

TEST ITEM

Station Call. Exide. Model FHC 19. Call \#51

PARTICULARS

Dec. 7/94. TIme 10, 00. Tamp('O) 24, Humidity(X) 29. Prass (kPa) 100.5. Graph 5411. Record 0

SPECIFICATIONS

Specs IEEE 344. Conditions operating, table limit

ANALYSIS

Type Maximax. Damping (z) 5. B.W. = 1/12 Octaves, Axis Z-bose, Shaker tri-oxial. $Z P X=2.7 \mathrm{~g}$

ACCELEROMETER

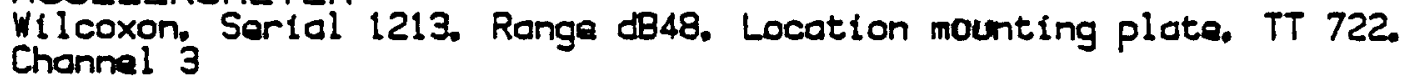




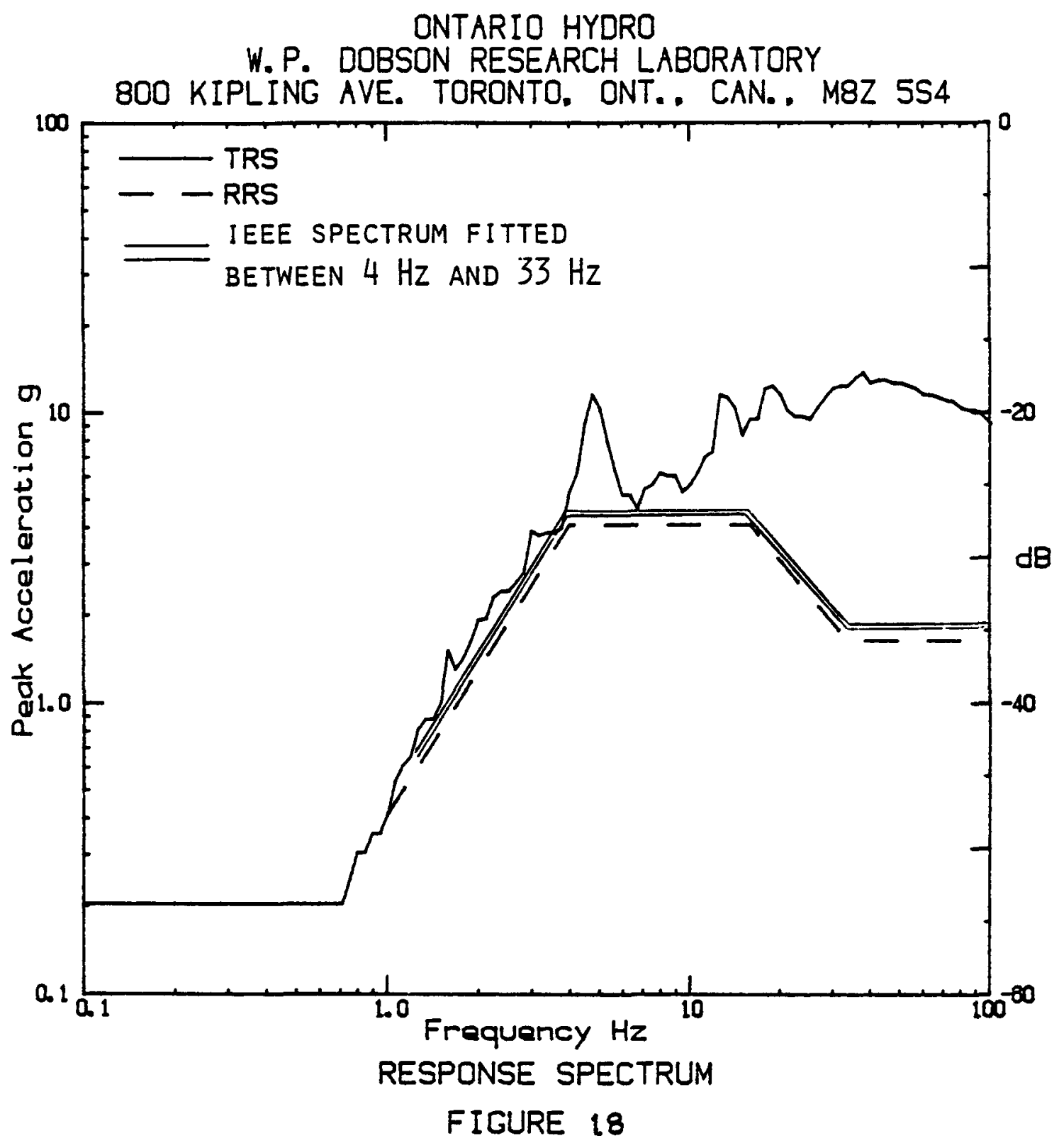

TEST ITEM

Station Cell. Exide. Model FHC 19, Cell \#23

PARTICULARS

Dec. 7/84, Time 1: 45. Temp('C) 24, Humidity (Z) 29. Press (kPa) 100.5. Graph 5415. Record 0

SPECIFICATIONS

Specs IEEE 344. Conditions operating, toble limit

ANALYSIS

Type Maximax, Damping (z) 5. B. W. = 1/12 Octaves, Axis X-bose. Shaker tri-axial. ZPẌ=1.9 9

ACCELERDMETER

Wilcoxon. Serial 1214. Range dB48. Location mounting plate. TT 726. Channel 1 


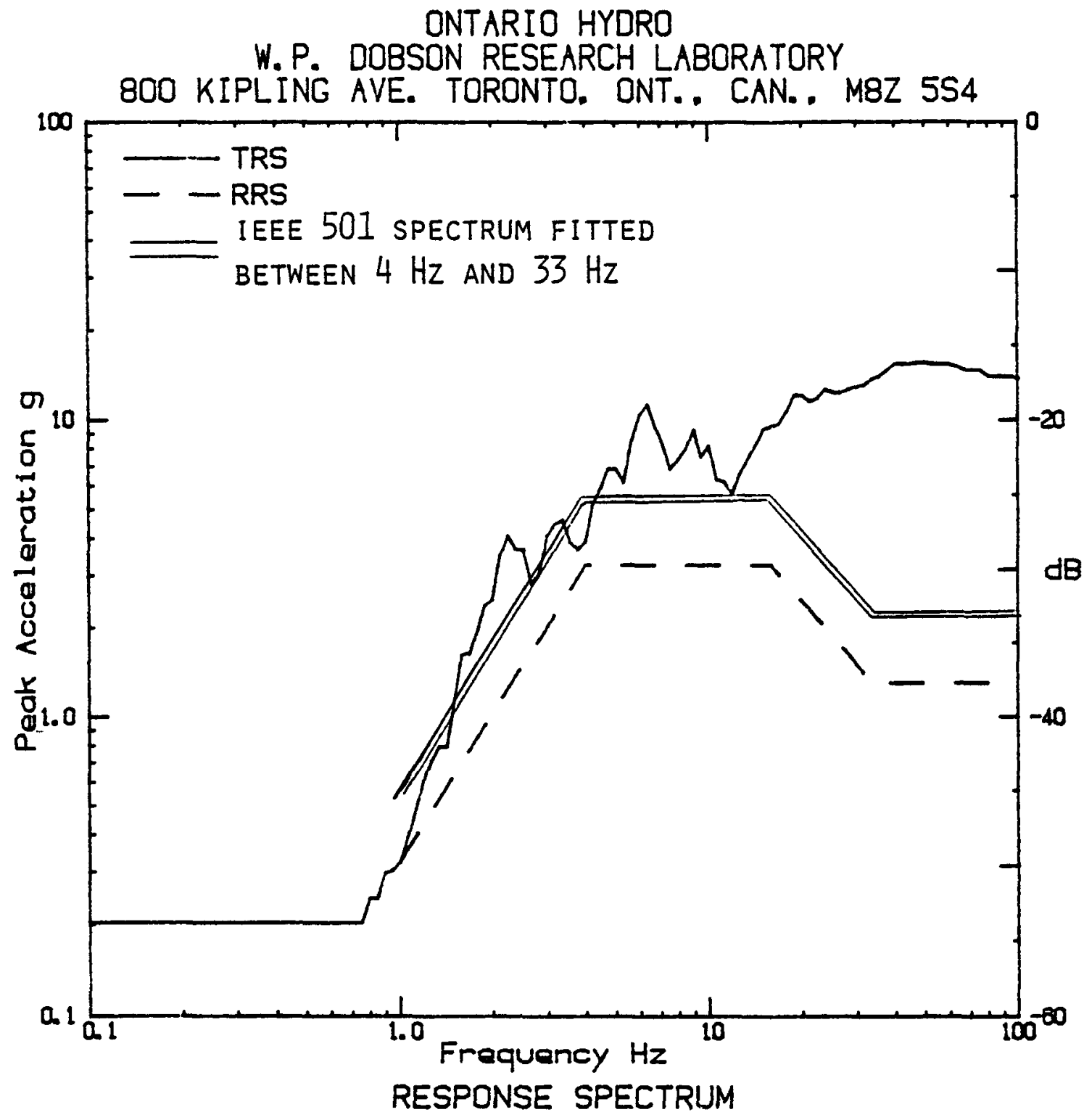

FIGURE 19

TEST ITEM

Station Call. Exide. Modal FHC 19. Call \#23

PARTICULARS

Dec, 7/84, Time 1: 45. Temp('C) 24, Humidity( $(2)$ 29. Press (kPa) 100.5. Graph 5416. Record 0

SPECIFICATIONS

Specs [EEE 344, Conditions operating, table limit

ANALYSIS

Type Maximax. Damping (z) 5, B. W. = 1/12 Dctoves, Axis Y-base.

Shaker tri-OXial. ZPX $=2.29$

ACCELEROMETER

Wilcoxon. Serial 1215. Range dB48. Location mounting plate. TT 726. Channel 2 


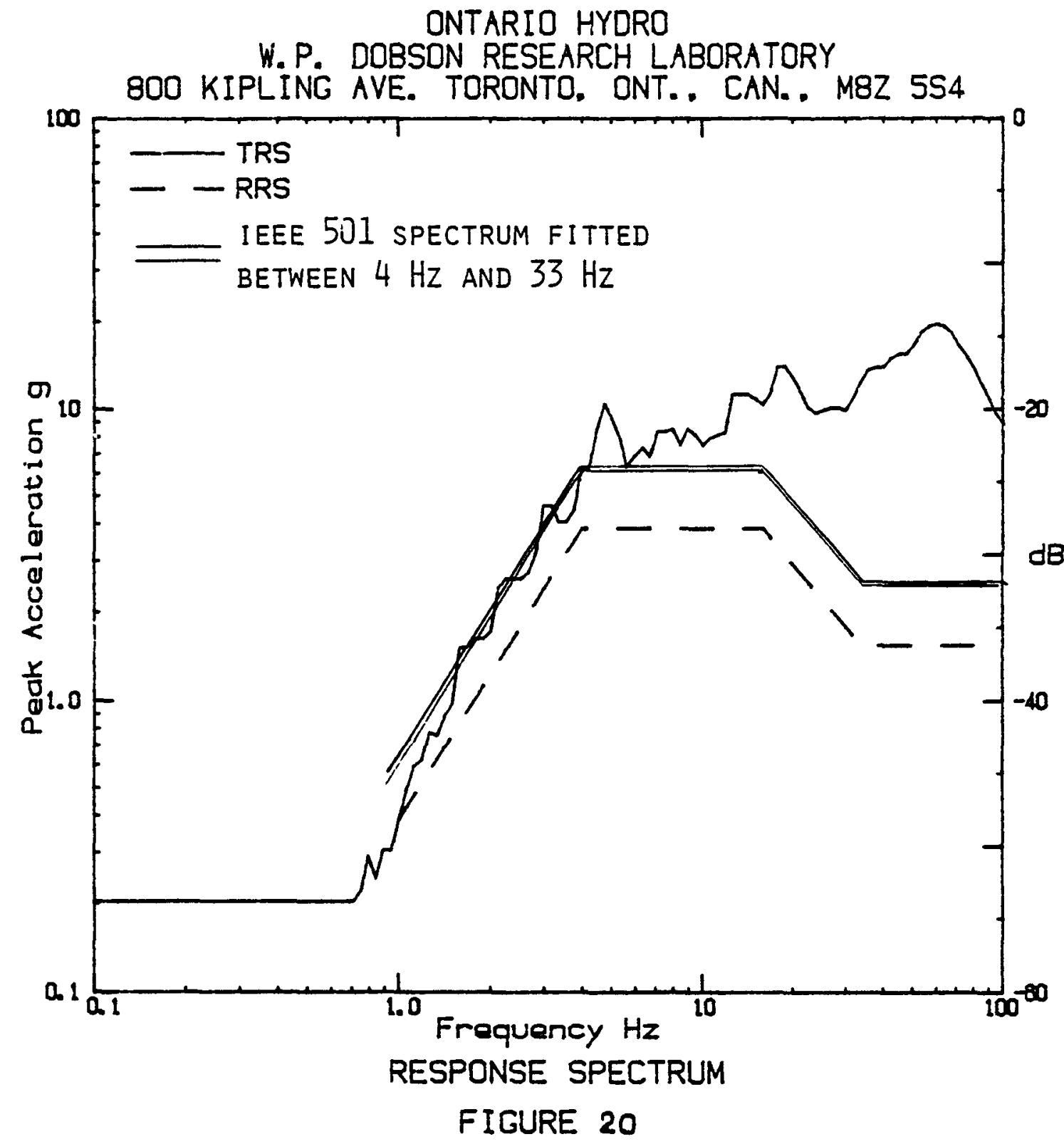

TEST ITEM

Station Cell. Exida. Modal FHC 19, Call $\# 23$

PARTICULARS

Dec. 7/84, Time 1845. Tamp('C) 24. Humldity(z) 29. Prass (kPa) 100. 5. Graph 5417. Record D

SPECIFICATIONS

Specs IEEE 344. Conditions operating. table Iimit

ANALYSIS

Type Maximax. Damping (D) 5, B. W. = 1/12 Octoves, Axis Z-base. Shaker tri-axial. $Z P X=2.5 \mathrm{~g}$

ACCELEROMETER Wilcoxon. Serial 1213. Range dB48. Location mounting plate. $T T 726$. 


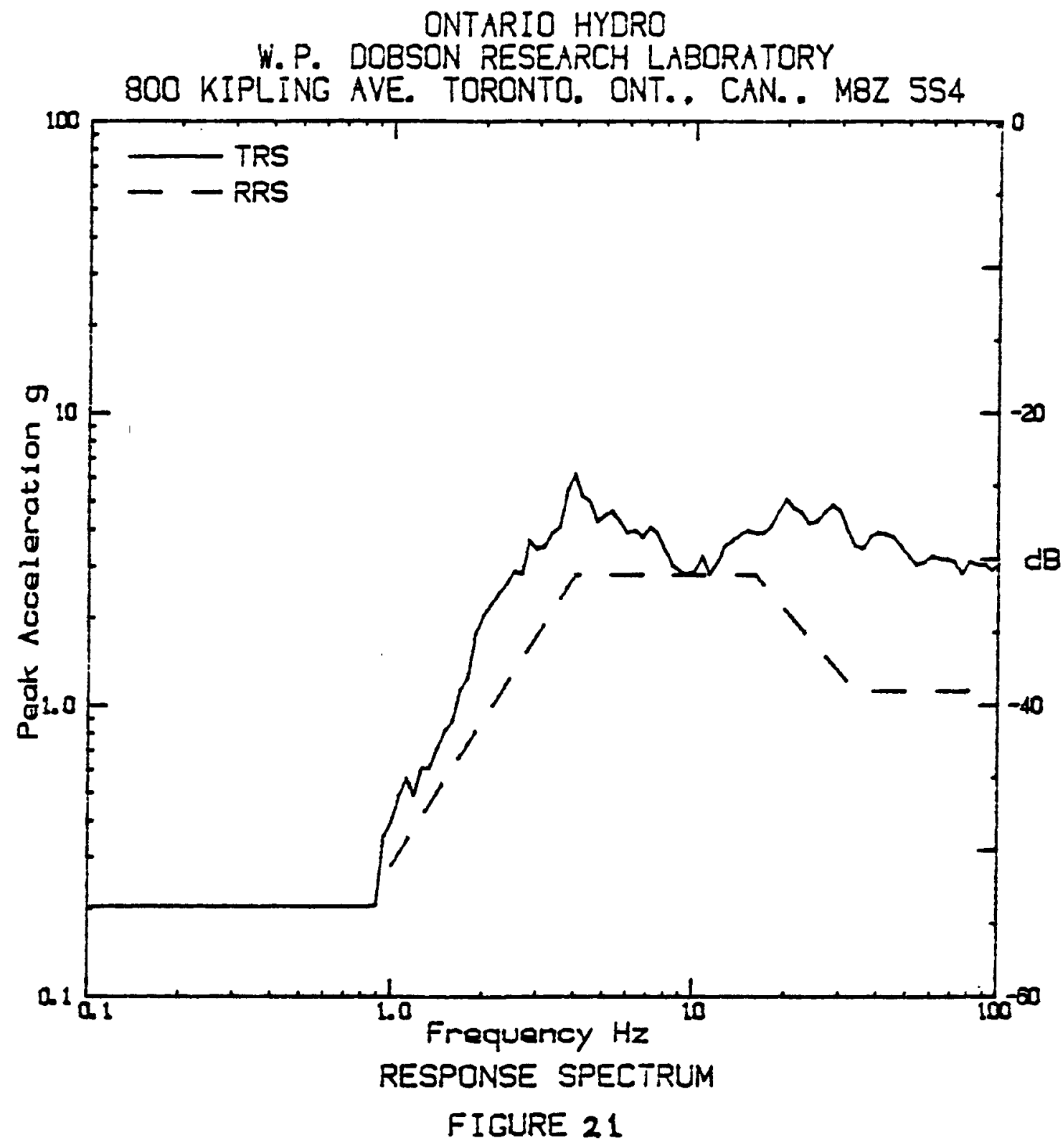

TEST ITEM

Station calls \& Rack. Exide. Model FHC-19, Seriol 15, 23, 10. Calvert Cliffs N.P.P.

PARTICULARS

July 24/84, Time 2.44. Tomp('O) 23. Humiditycos 55, Prase (kPa) 100.3. Graph 5248

SPECIFICATIONS

Specs IEEE 501. Conditions oparating a 1 hour rate. span 7

ANALYSIS

Type Meximax, Damping $\cos$, B. $W_{0}=1 / 12$ Detoves, Axis $X_{0}$ Shaker tri-axicl. $Z P A=1.13 g$

ACCELEROMETER

Vilcoxon Sarial S771. Range d849, Location bcee-mounting plate. Channel 1 


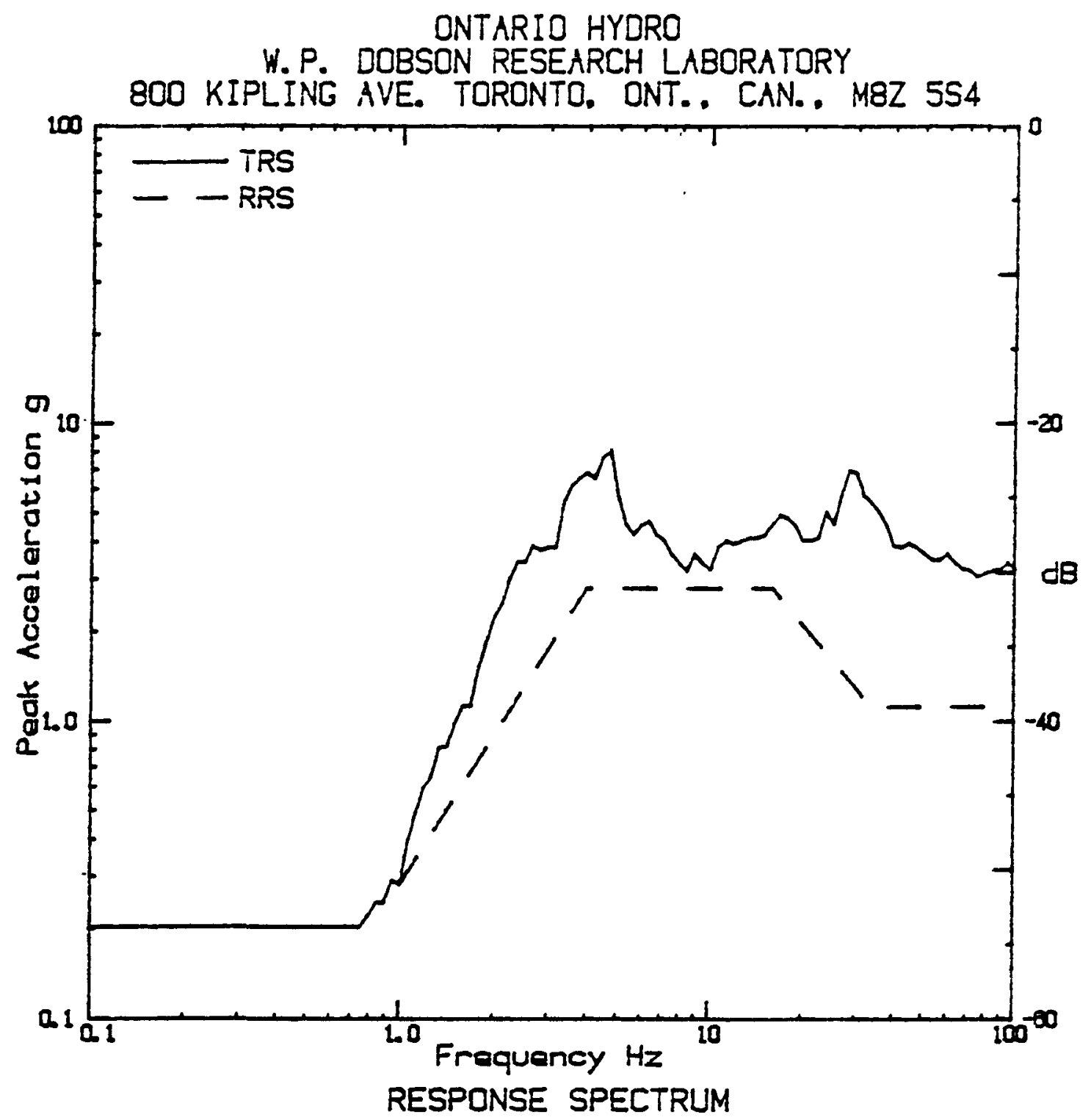

FIGURE 22

TEST ITEM

Station calls \& Rack, Exide. Madal FHC-19. Sarial 15.23. 10. Calvart Cliffs N.P.P.

PART ICULARS

July 24/84, Time 244. Tamp('D 23. Humidity (s) 55, Prass (kPo) 100 3. Groph 5250

SPECIFICATIONS

Specs IEEE 501. Conditions operating : 1 hour rate. span 7

ANALYSIS

iype Maximox, Demping (D) 5 , \& $W_{0}=1 / 12$ Detovas, Axis Z Shaker tri-axiol. $z P X=1.13 g$

ACCELEROMETER

Hilcoxon Sariol S297. Range d849, Location bose-mounting plate. Channel 3 


\section{APPENDIX A}

\section{EARTHQUAKE MOTION AND RESPONSE SPECTRA}

The way that a piece of equipment or structure responds to an earthquake will depend on the intensity of the event, and on the relationship between frequency content of the earthquake and the natural frequencies of the structure.

A convenient way of expressing the combination of intensity and frequency content of an earthquake is through the use of a graph known as a response spectrum. A response spectrum is made up by calculating the response level (acceleration, velocity or displacement) of a family of hypothetical single degree-of-freedom mechanical oscillators to the earthquake motion, and plotting these against frequency. A particular seismic "environment" is described by a set of spectra that define the response for different directions and levels of structural damping. The response of a simple structure to an earthquake can be estimated from the level of the appropriate spectra at the natural frequencies of the structure.

Response spectra deal with the response of structures to earthquake motion and contain no explicit information on the peak accelerations. However, it is known that earthquake motions is predominantly in the low frequency range $(1-10 \mathrm{~Hz})$ and that there will be relatively little amplification of the response of high frequency oscillators. Thus, for typical earthquake timehistories, the peak acceleration response for the oscillators. at the high end of the frequency range will be quite close to the peak acceleration of the base motion from which the spectrum was generated. High frequencies correspond to short vibration periods and, in the jargon of the trade, the acceleration response $t$ the high frequency end of the spectrum $(33 \mathrm{~Hz}$ or above) is known as the Zero-Period Acceleration (ZPA). The ZPA is commonly taken as being equivalent to the peak acceleration of the seismic motion.

Response spectra are commonly used to define the seismic environments for structures or equipment that must survive earthquakes. Unless there is a large amount of site-specific data available, the spectra specified for a particular project are normally based on standard curves that have been developed to represent a broad range of possible conditions. The spectral curve defined in IEEE $501 / 11 /$ is typical. This standard specifies the relative intensity of the spectrum over the frequency range. The absolute intensity will depend on site conditions. For convenience, the absolute intensity is expressed as the $\mathrm{ZPA}$. 
When a particular piece of equipment is seismically qualified to IEEE 501, the test response spectra (ie. the response spectra calculated from the test motions) will be compared to the standard shape. The qualified level is the ZPA of the normalized curve that lies just below the test spectrum over the seismic frequency range $(1-33 \mathrm{~Hz})$.

For an efficient test, the test spectrum should closely match the standard spectral shape. However, in practical testing, the experimental curve will often "overshoot" the desired curve over certain frequency ranges. This may be because of mechanical limitations in the test rig. For example, the shaker table used in this series of tests has a limited stroke (displacement) so that it $s$ difficult to generate very high response levels at low frequencies. Thus, when the rig is run at high power levels, the test motions often produce response spectra which are high in the high frequency range (above $5 \mathrm{~Hz}$ ) and low at low frequencies, relative to the standard IEEE 501 shape. When these test spectra are fitted to the standard shape by strict rule, the result is a considerable overshoot for much of the high frequency range. This means that the $\mathrm{ZPA}$ taken from the standard curve is far below the peak accelerations that were actually encountered.

As mentioned above, the standard shape was developed to represent a broad range of seismic conditions, structural supports and low frequencies so that equipment with low natural frequencies will be adequately tested. However, in the case of the battery cells and racks, all of the structural modes of vibration have been found to have relatively high natural frequencies. This means that these devices will not be significantly effected by the low frequency component of the input motion. We believe that it is reasonable in this case to ignore the low frequency end of the experimental spectra and to fit the standard shape over a frequency range of 4-33 $\mathrm{kz}$. This has the effect of increasing the $Z P A$ of the standard curve to a value that more accurately reflects the maximum accelerations encountered in each test. 


\section{APPENDIX B}

Seismic Testing of Calvert Cliffs Nuclear Power station Batteries Cell Inspection and Capacity Tests

W. J. Janis

Ontario Hydro Research Division 
To Mr. B.A. Oliver

Manager

Electrical Design Dept

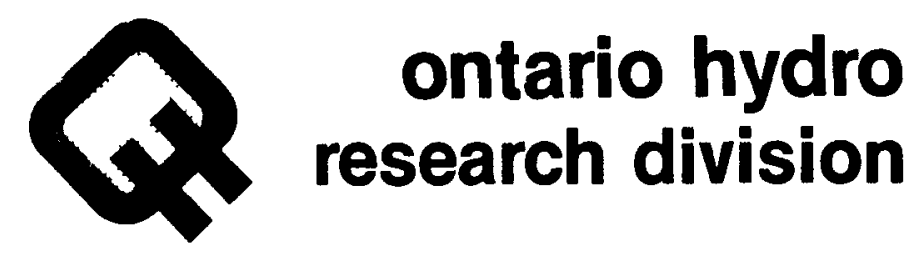
SEISMIC TESTING OF CALVERT CLIFFS NUCLEAR POWER STATION BATTERIES -
CELL INSPECTION AND CAPACITY TESTS

W.J. Janis

The performance and condition of 10-year-old, calcium alloy, lead-acid cells were monitored before, during and after seismic testing to determine cell resistance to damage by seismic stresses. Six FHC-19 cells were tested and none failed electrically during seismic testing. only two seismically tested cells could deliver $80 \%$ of rated capacity after testing. Low capacities were primarily due to loss of active material from positive plates although chemical corrosion of bus material may have been a contributing factor. Dissected cell positive bus material was not cracked but was relatively brittle and corroded. Positive plate active material was hard and cracked.

\subsection{INTRODUCTION}

Sandia National Laboratories (SNL) is currently under contract to the United states Nuclear Regulatory Commission (NRC) to conduct studies on the degradation and failure modes of safety related components used in nuclear power plants. Of particular interest to SNL and NRC, and also to ontario Hydro, is the significance of aging on the seismic-accident survivability of stationary, class lE, emergency power batteries.

Because of mutual interest, experience in seismic testing of batteries and the availability of special test facilities, Ontario Hydro was sub-contracted by SNL to carry out seismic fragility tests of naturally aged, lead-acid cells from the Calvert cliffs Nuclear Generating station, Lusby, Maryland. Following guidelines set out by SNL, a research program was developed by the Electrical Design Department (Design and Development Division), and the Mechanical and Chemical Research

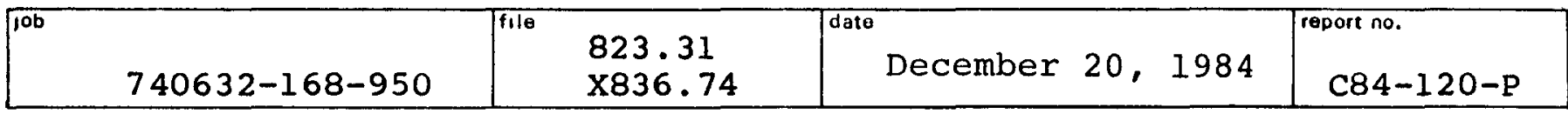


Departments (Research Division). In this program the performance and condition of aged cells were monitored before, during and after shaker table testing under simulated earthquake conditions.

This report presents cell condition and performance data obtained during the test program.

\subsection{TEST CELLS}

Ten Exide FHC-19 cells were selected at random by Baltimore Electric and Gas Company personnel from a large number of cells recently released after 10 years of service. All cells were delivered to the Battery Research Facility in good condition.

The test cells were all of the lead-calcium type, that is the grid material of these cells contained a small amount of calcium, less than 0.18 , alloyed with lead. Cell specifications supplied by the manufacturer are given in Appendix 1 .

\subsection{EXPERIMENTAL}

\subsection{Cell Inspection and Initial conditioning}

On delivery to Ontario Hydro Research Division (OHRD) the cells were inspected for leaks, excess sediment, broken posts, cracks, crazing and any damage which might have been induced by handling during transportation. No significant damage was observed and all cells were therefore put on equalizing, then floating charge at 2.25 and 2.15 volts per cell (VPC), respectively. Cells were placed on floating charge prior to, and between, capacity tests to minimize capacity loss through self-discharge.

During storage, the specific gravities of the cells were maintained between 1.200 and 1.220 , corrected to $25^{\circ} \mathrm{C}$ per IEEE standard 450-1980 / $/$. Specific gravities, cell voltages, electrolyte levels and temperatures were monitored and adjusted as necessary to maintain the cells in serviceable condition.

\subsection{Initial Capacity Tests}

Following inspection, charge equalization, and a minimum of $24 \mathrm{~h}$ float charging, all serviceable cells were discharged at the manufacturer's specified $3 \mathrm{~h}$ rate to a final cell potential of 1.75 VPC. The discharge tests provided benchmark capacity data for cells selected for seismic test and were carried out per reference 1 as follows: 
1. Three or four cells and a resistance load were connected in series and the cells were discharged at a constant current following the procedure outlined in OHRD report No $E 76-85-\mathrm{H} / 2 /$.

2. Cell potentials, discharge currents and temperatures were monitored during the discharge test. The data were recorded at 5 min intervals.

3. Discharged cells were recharged in series at a potential of $2.25 \mathrm{~V}$ for $35-70 \mathrm{~h}$, followed by sustained float charging at $2.15 \mathrm{~V}$.

\subsection{Cell Discharge During Seismic Testing}

To assess the immediate effect of a seismic event on cell performance, cells were kept on discharge during seismic tests and cell voltages and currents were monitored continuously during the tests. A one hour discharge rate was used for the Calvert cliffs cells to simulate a high load emergency service condition.

Discharge was initiated a few seconds prior to the first $30 \mathrm{~s}$ seismic event and was continued until the cell either failed during a seismic event or passed the scheduled sequence of seismic events. Failure was defined as the inability of a cell to maintain a potential greater than $1.75 \mathrm{~V}$ while under a constant current discharge at the $1 \mathrm{~h}$ rate.

\subsection{Post Seismic Capacity Tests}

After seismic testing, all cells which did not fail were discharged at the $3 \mathrm{~h}$ rate. The procedure was the same as for the initial capacity tests.

\subsection{Cell Disassembly and Material Studies}

Four test cells were disassembled following seismic and capacity testing to identify changes in internal components resulting directly from seismic testing. A photographic record of abnormalities was obtained and samples of grid connector bus material were taken for later detailed metallurgical analysis.

\subsection{RESULTS AND DISCUSSION}

\subsection{Cell Inspection}

Ten cells from Calvert Cliffs NGS arrived at OHRD on June 19, 1984. Except for one small crack in the cell jar top of cell 35 no external damage was noted. 
Regular horizontal and vertical cracks were observed in the sponge lead active material of the negative plates of all cells. The cracks followed the rectangular pattern of the negative grid supports and gave the impression that the active material had shrunk slightly during service (see photograph 12).

Numerous $1-3 \mathrm{~mm}$ diameter blisters of negative active material were observed, mostly at the top of the negative plates, during the cell inspection. Several blisters were broken and appeared to be hollow (see photographs 12 and 13).

Positive plate packs of most cells were slightly bowed in one direction and in two cells, cells 25 and 5, one outer positive plate was severely bowed away from the pack, leaving a gap of approximately $\mathrm{l} \mathrm{cm}$ at the mid-height of the cell pack (see photograph 14).

About 3 - $5 \mathrm{~mm}$ of sediment were present in all cells. Most of the sediment was the characteristic dark brown colour of lead oxide. Small pockets of white lead sulphate were also observed (see photograph 15).

The deposit in one cell, cell 23, was mostly white lead sulphate.

On close inspection of the edges of many of the positive plates of FHC-19 cells, small, intermittent gaps between the positive plates and separators were observed. Although it was difficult to examine the gaps from outside the cell, many appeared to contain positive plate active material detached from the positive grids.

The significant warping and sediment observed during cell inspection were uncharacteristic of lead-calcium alloy cells. In such cells warping and sediment are usually minimal.

Approximately $0.5 \mathrm{~L}$ of water was added to each of cells 5,10 , 15,55 and 56 and 1 L was added to cell 57, to bring the electrolyte level up to operating requirements. The average specific gravity and cell potential, before water addition, were 1.187 and $2.03 \mathrm{~V}$, respectively.

\subsection{Initial Capacity Tests}

Capacity data and pre-test specific gravities and open circuit cell potentials are presented in Table I. Only cell 56 failed to meet the IEEE recommended acceptance criterion of $80 \%$ rated capacity. 
TABLE I

CAPACITY TEST DATA*

\begin{tabular}{|c|c|c|c|c|}
\hline $\begin{array}{c}\text { Cell } \\
\text { Number }\end{array}$ & $\begin{array}{c}25^{\circ} \mathrm{C} \\
\text { Gravity } \\
\text { Prior to } \\
\text { Discharge** }\end{array}$ & $\begin{array}{c}\text { Open } \\
\text { Circuit } \\
\text { Potential } \\
\text { (Volts) }\end{array}$ & $\begin{array}{c}\text { Time to } \\
\text { 1.75 VPC at } \\
3 \text { rate of } \\
354 \text { A (min) }\end{array}$ & $\begin{array}{c}\text { Per Cent } \\
\text { Rated } \\
\text { Capacity at } \\
\text { h hate }\end{array}$ \\
\hline 5 & 1.191 & 2.11 & 155 & 86 \\
10 & 1.196 & 2.13 & 180 & 100 \\
13 & 1.196 & 2.12 & 164 & 91 \\
15 & 1.205 & 2.07 & 155 & 86 \\
23 & 1.201 & 2.12 & 155 & 86 \\
35 & 1.205 & 2.08 & 155 & 94 \\
51 & 1.205 & 2.08 & 170 & 92 \\
55 & 1.196 & 2.13 & 166 & 67 \\
56 & 1.196 & 2.11 & 121 & 100 \\
57 & 1.195 & 2.09 & 180 & \\
\hline
\end{tabular}

* Cells equalized at 2.25 VPC for 5 days, then float charged at 2.15 VPC for 7 days prior to discharge.

* Cell gravities were all between $1.200-1.210$ when the cells were taken off float charge but prior to test 2 days later had decreased slightly, as a result of self-discharge, to the tabulated values.

After initial capacity tests, the cells were recharged at 2.15 VPC. Following 7 days of float charging, cell specific gravities, excluding cell 56, averaged 1.206 and both open circuit voltages and charging current had stabilized. Approximately $2.1 \mathrm{~V}$ and $10 \mathrm{~A}$ per cell, respectively. Following Appendix B of IEEE std 450/1/, stabilization of the voltage-regulated charging current at the charging voltage was taken as an indication that the cells in question were charged and ready for seismic tests.

\subsection{Cell Discharge During Seismic Testing}

No sudden loss of cell potential was observed for any cell during seismic testing up to the capacity of the shaker table. The pass/fail results are summarized in Table II and presented in more detail in Appendix 2. Details of the seismic testing procedure and fragility level assessment are presented in OHRD report 84-418-P /3/. 
The data in Table II indicate that all the Calvert cliffs test cells survived seismic stresses up to the capacity of the shaker table test equipment.

TABLE II

DISCHARGE DATA SUMMARY - SEISMIC EVENT TESTS

\begin{tabular}{|c|c|c|c|c|}
\hline \multirow[b]{2}{*}{$\begin{array}{l}\text { Cell } \\
\text { Number }\end{array}$} & \multirow{2}{*}{$\begin{array}{c}\text { Pass/Fail } \\
\text { at } 1 \mathrm{~h} \\
\text { Discharge } \\
\text { Rate* }\end{array}$} & \multicolumn{2}{|c|}{$\begin{array}{l}\text { Cell Potential (V) } \\
\text { While Under Load }\end{array}$} & \multirow{2}{*}{$\begin{array}{c}\text { Total } \\
\text { Time on } \\
\text { Discharge } \\
\text { (s) }\end{array}$} \\
\hline & & $\begin{array}{l}\text { Before } \\
\text { Testing }\end{array}$ & $\begin{array}{l}\text { After } \\
\text { Testing }\end{array}$ & \\
\hline $\begin{array}{l}10 \star \star \\
15 \star \star \star \\
23 \star \star \\
35 \\
51 \\
57 \\
15 \star \star \star\end{array}$ & $\begin{array}{l}\text { Pass } \\
\text { Pass } \\
\text { Pass } \\
\text { Pass } \\
\text { Pass } \\
\text { Pass } \\
\text { Pass }\end{array}$ & $\begin{array}{l}1.841 \\
1.864 \\
1.841 \\
1.860 \\
1.759 \\
1.869 \\
1.841\end{array}$ & $\begin{array}{l}1.847 \\
1.876 \\
1.847 \\
1.860 \\
1.828 \\
1.857 \\
1.847\end{array}$ & $\begin{array}{l}310 \\
315 \\
310 \\
242 \\
342 \\
347 \\
310\end{array}$ \\
\hline
\end{tabular}

* 679 Amperes

* Multi-cell Test

*** Cell 15 was used in both single cell and multi-cell tests. (Multi-cell test results are given at the bottom of the table.)

\subsection{Post Seismic Capacity Tests}

Post test discharge capacities were determined for all six cells which survived seismic testing. The data are compared to pre-seismic values in Table III. Also in Table III is the cumulative capacity for the cells, as measured from the start of the seismic test, expressed as a percentage of the $3 \mathrm{~h}$ rated capacity. The required calculations to convert discharge times at the $1 \mathrm{~h}$ rate to discharge times at the $3 \mathrm{~h}$ rate is provided in Appendix 3.

The Table III data indicate a loss of discharge capacity for all cells except cell 51 as a result of seismic testing. The cell capacities of cells 10, 15, 23 and 35 , as measured from the start of the seismic event series, did not meet the acceptance criteria of $\geq 80 \%$ of rated capacity. 
TABLE III

CELL CAPACITIES BEFORE AND AFTER SEISMIC TESTING

\begin{tabular}{|c|c|c|c|c|c|c|c|}
\hline \multirow[b]{2}{*}{ Cell } & \multicolumn{4}{|c|}{$\begin{array}{l}\text { Time to } 1.75 \mathrm{VPC} \\
\text { at } 3 \mathrm{~h} \text { Rate (min) }\end{array}$} & \multicolumn{3}{|c|}{$\begin{array}{c}\text { Percent of Rated Capacity } \\
\text { at } 3 \mathrm{~h} \text { Rate }\end{array}$} \\
\hline & $\begin{array}{l}\text { Pre- } \\
\text { Seismic }\end{array}$ & $\begin{array}{l}\text { Post- } \\
\text { Seismic* }\end{array}$ & $\begin{array}{l}\text { Post } \\
\text { Plus }\end{array}$ & $\begin{array}{l}\text {-Seismic } \\
\text { Seismic** }\end{array}$ & $\begin{array}{c}\text { Pre- } \\
\text { Seismic }\end{array}$ & $\begin{array}{l}\text { Post- } \\
\text { Seismic* }\end{array}$ & $\begin{array}{l}\text { Post-Seismic } \\
\text { Plus Seismic** }\end{array}$ \\
\hline $\begin{array}{l}10 \\
15 \\
23 \\
35 \\
51 \\
57\end{array}$ & $\begin{array}{l}180 \\
155 \\
155 \\
155 \\
170 \\
180\end{array}$ & $\begin{array}{l}104 \\
104 \\
121 \\
121 \\
162 \\
149\end{array}$ & & $\begin{array}{l}118 \\
131 \\
135 \\
132 \\
177 \\
164\end{array}$ & $\begin{array}{r}100 \\
86 \\
86 \\
86 \\
94 \\
100\end{array}$ & $\begin{array}{l}58 \\
58 \\
67 \\
67 \\
90 \\
83\end{array}$ & $\begin{array}{l}66 \\
73 \\
75 \\
73 \\
98 \\
91\end{array}$ \\
\hline
\end{tabular}

* Cells not recharged following seismic testing.

** Capacity during seismic test at $1.0 \mathrm{~h}$ rate converted to $3 \mathrm{~h}$ capacity and added to post-seismic capacity, as discussed in Appendix 3 . 


\subsection{Cell Disassembly and Material Study}

Seismically tested cells $10,15,35$ and 57 were disassembled and inspected for internal damage. Common features identified during the inspection are documented in Photographs $1-12$ and summarized below. Detailed post-mortem information on each cell is presented in Appendix 4.

Photographs 1 and 2 show cell posts and the top part of the connecting bus for positive and negative terminals, respectively, of FHC-19 cell 57. No cracks were observed in either terminal and the busses did not break away from the plates when the cell internals were lifted from the cell jar by means of the positive and negative posts (Photographs 3 and 4 ).

A bottom view of the positive and negative bus and plate hanger area of cell 15 is shown in photographs 5 and 6 , respectively. Again, no cracks attributable to seismic testing were observed although evidence of slight chemical attack of positive bus material along casting imperfections was noted.

The conditions shown in photographs 1 - 6 were typical of all dissected cells.

Photographs 7 and 8 show the result of vigorous hammering of positive posts of cells 57 and 35, respectively. In both cases during hammering the vertical section of the connecting bus moved with the posts and relative to the horizontal section. The relative motion caused numerous fractures along the joint between vertical and horizontal bus sections.

The posts were hammered until the bottoms of the posts contacted the tops of the plate packs, at which point the formerly vertical bus sections were approximately 45 degrees to the horizontal. For cell 57 the hammering resulted in cracking, bending and partial disconnection of the vertical bus section from the horizontal bus section. For cell 35 the result of hammering was total disconnection of the post/vertical plate section from the horizontal plate section.

After photograph 7 was taken, the positive post/vertical bus section of cell 57 was easily disconnected from the horizontal plate section by bending it toward the vertical by hand.

The cross-sections available for conduction in cells 57 and 35 , the metaliic area of Photographs 7 and 8 , were measured after removal of the disconnected bus section and found to be approximately 608 and 458 , respectively, of the total cross-section of the horizontal busses. The non-metallic area of the bus cross-sections was the characteristic brown of lead 
oxide, indicating chemical attack of cracked or weak positive bus lead areas by sulphuric acid during service.

Photographs 9, 10 and 11 show the conditions of abnormal positive plates from cells 57, 35 and 10, respectively.

For all cells the positive active material was abnormally hard and, in most cases, cracked. For cells 35 and 10 considerable fallout of active material was noted and the grids were expanded slightly due to swelling of active material during service.

The blisters and cracks, described in section 4.1, are shown in Photograph 12 for a negative plate of cell 35. The blisters were hollow and their position near the top of the plate suggests that they may be the result of gas emissions from electrolyte within the active material under the influence of an excessive charging voltage.

In general, both negative and positive plates were in poor condition. The negative plate active material was cracked and blistered while the positive plate material was hard and compressed. The cross-sectioned area available for conduction in positive busses appears to be abnormally low as a result of corrosion. Parts of the bus material were brittle.

Relative post seismic capacity test results for cells 57,35 and 10 ( 91,73 and 66\%, respectively) are consistent with the observations made of the positive plates and busses. The positive plate material of cell 57 was cracked primarily at the plate extremities while cracking in cell 35 plates was considerably more extensive. In cell 10, large areas of plate material had collapsed (Photographs 9-11). The positive bus material of cell 57 did not break during hammering while that of cell 35 , and subsequently cell 10, mounted in a vice, were broken under similar conditions.

\subsection{CONCLUSIONS}

1. All six FHC-19 cells selected for seismic testing provided uninterrupted power at required electrical potential under load during repeated and violent shaking.

2. Two of six seismically tested cells were capable of meeting the acceptance criterion of $80 \%$ of rated capacity after the tests. Four others failed to do so. 


\section{DOCUMENTATION PHOTOGRAPHS \\ CALVERT CLIFFS LEAD CALCIUM CELLS \\ (FHC-19)}
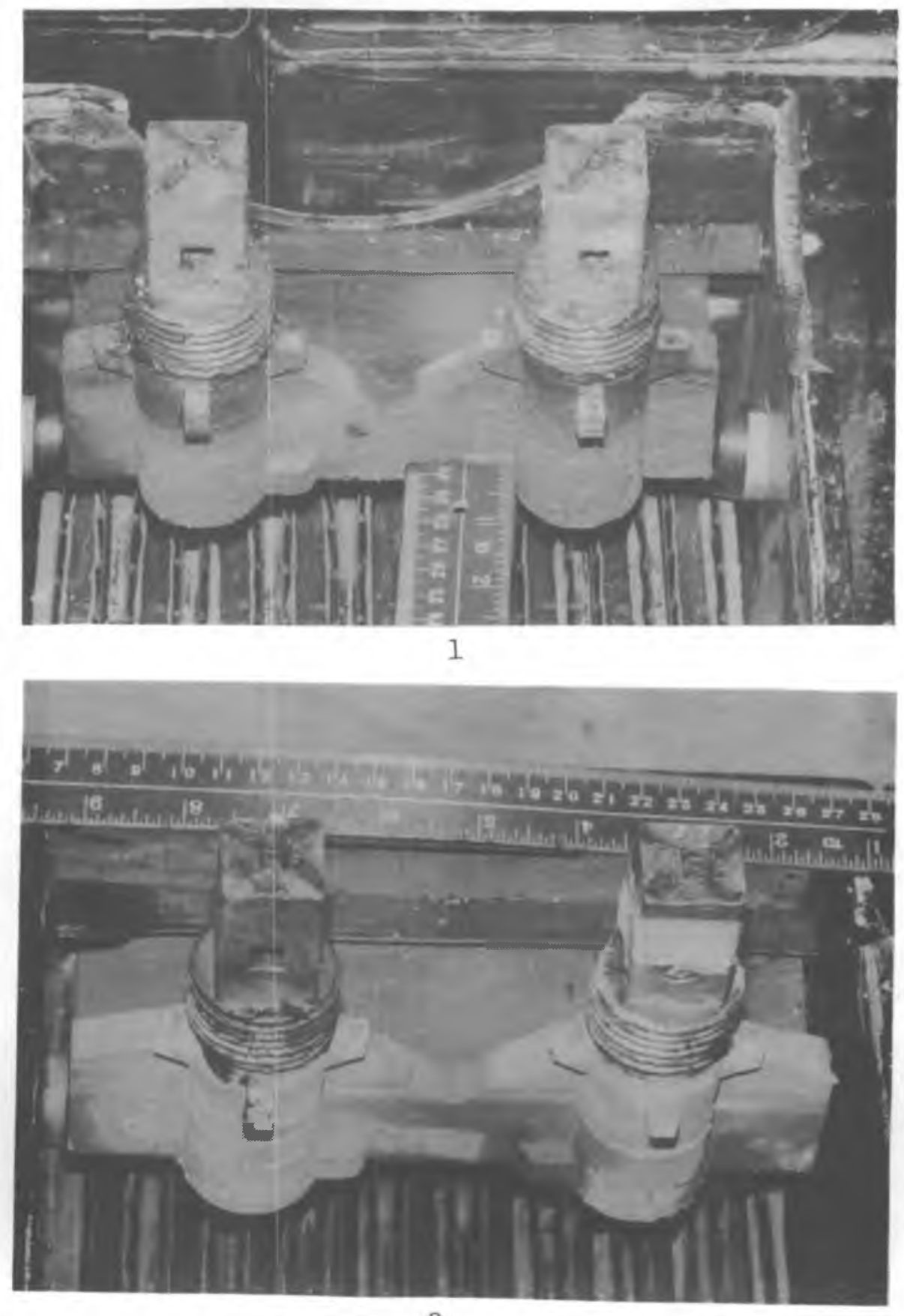

2

B-10- 


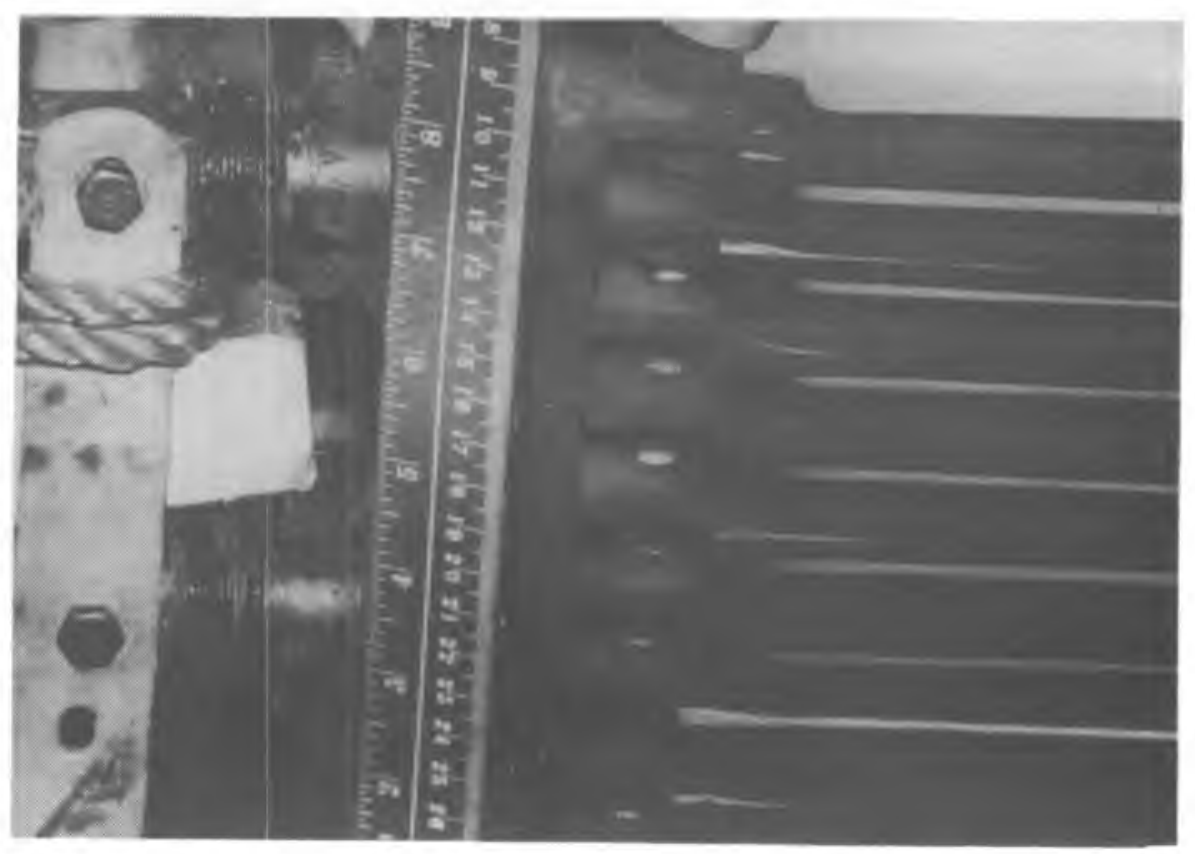

m

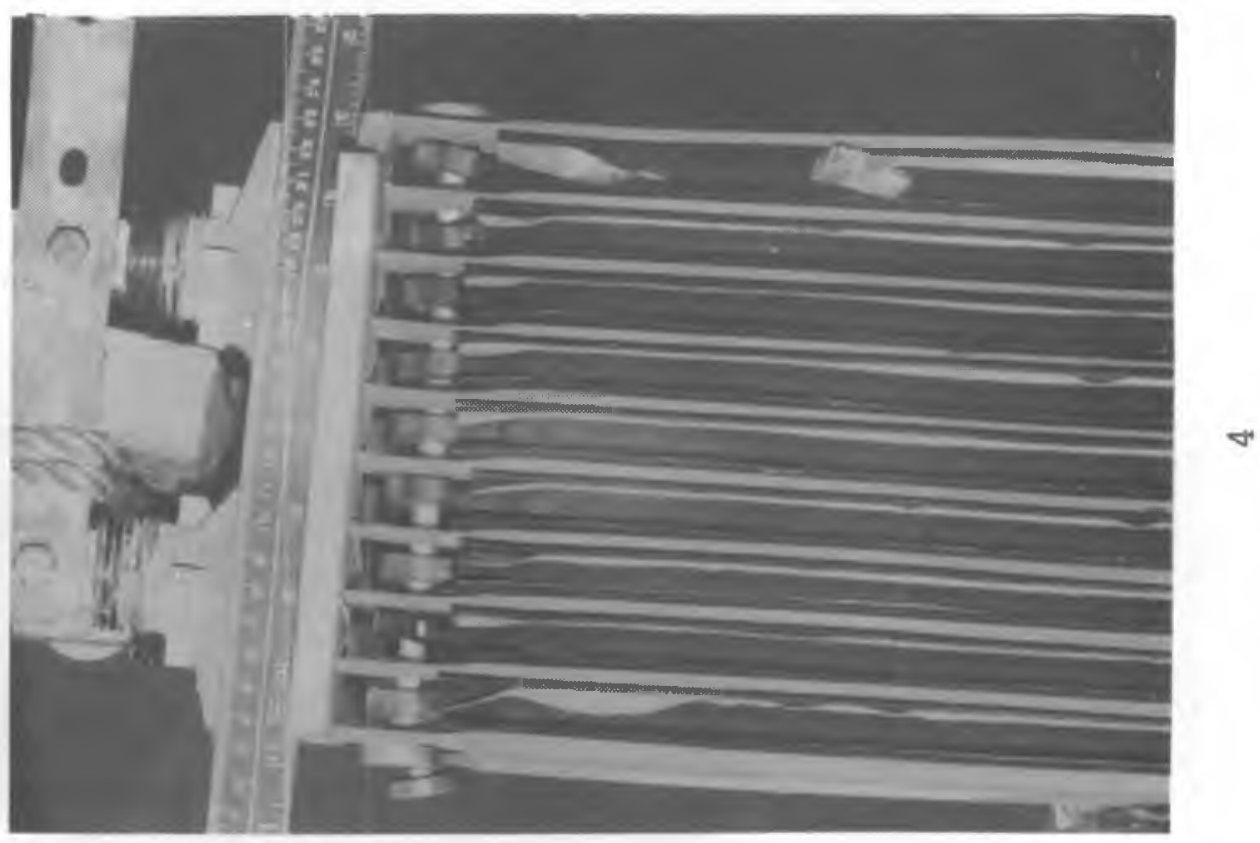




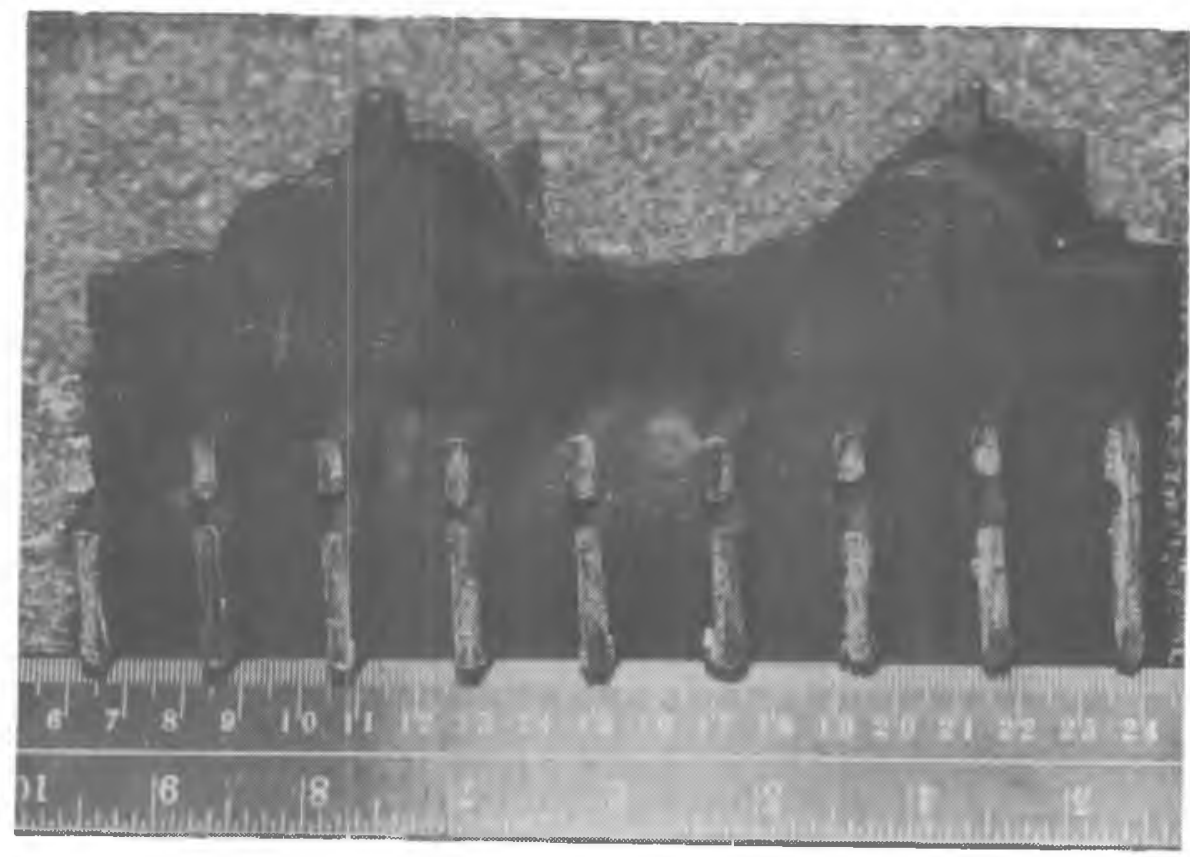

5

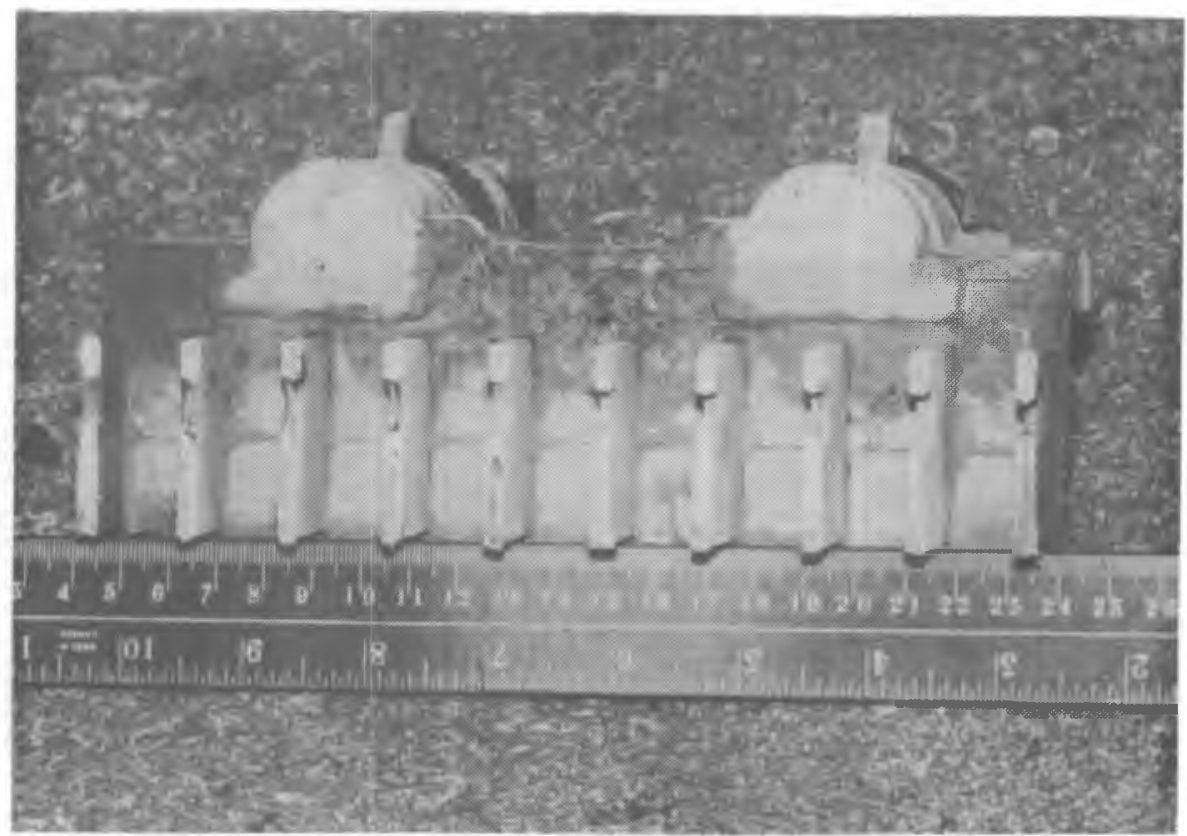




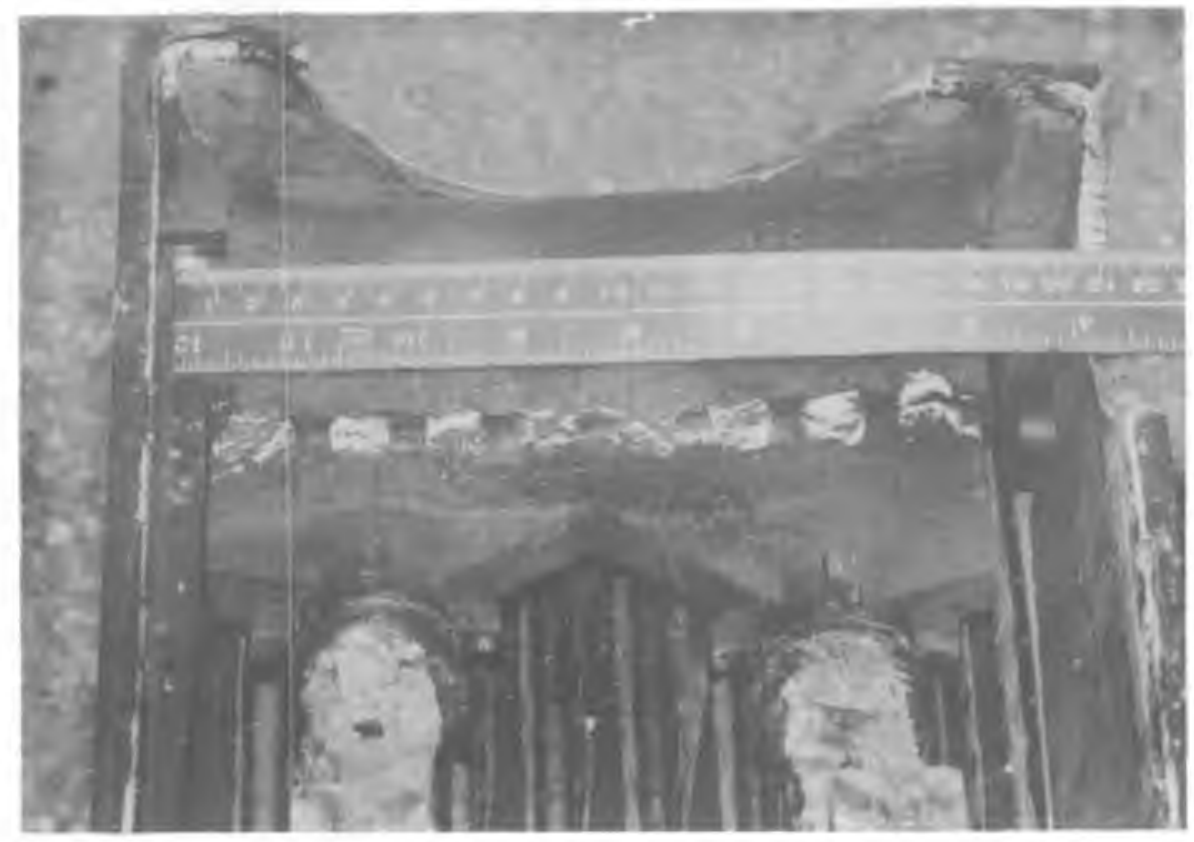

7

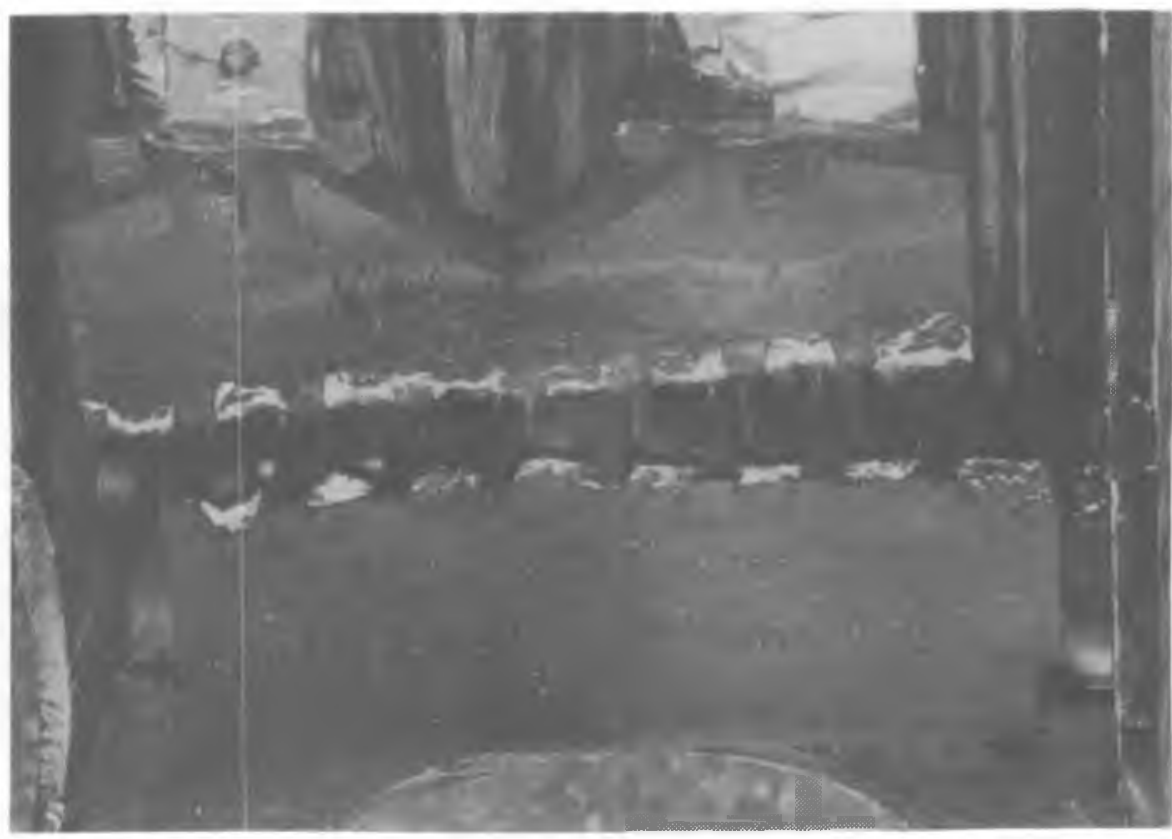

8

B-13-

C84-120 


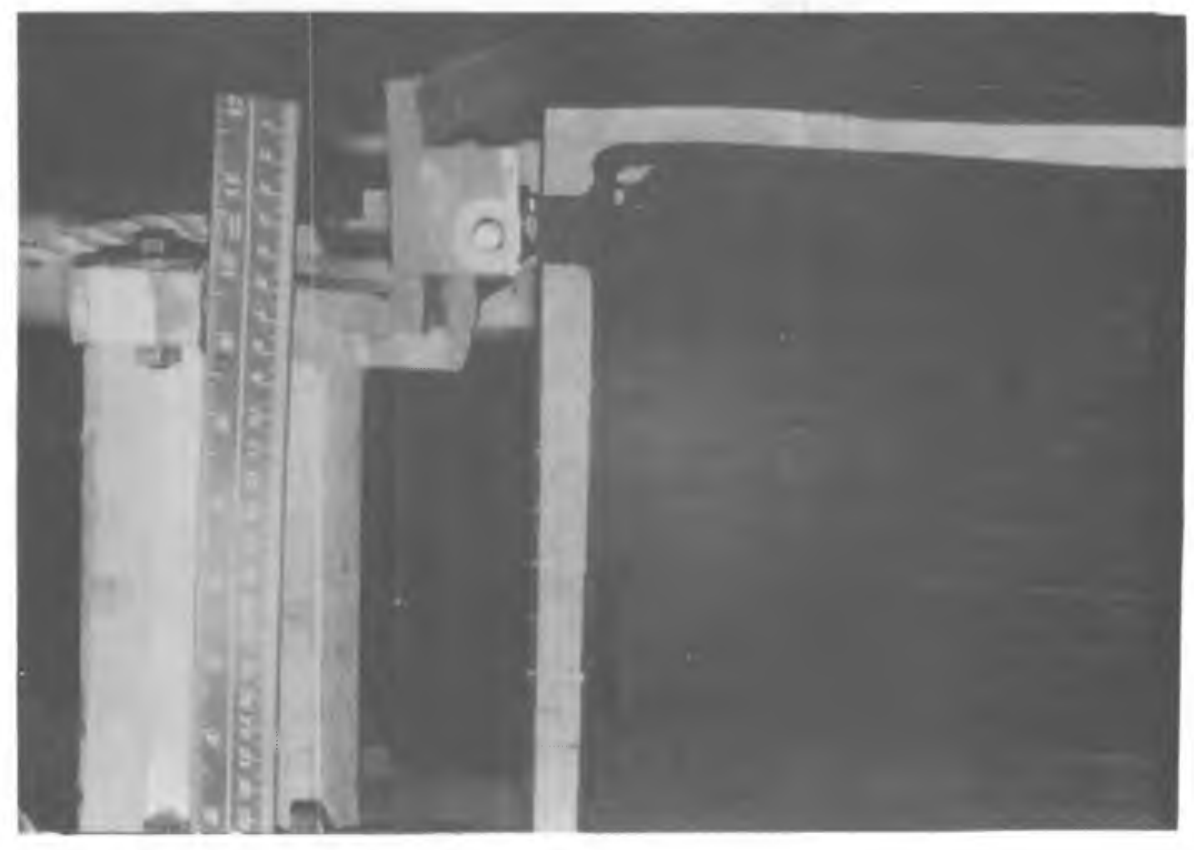

9

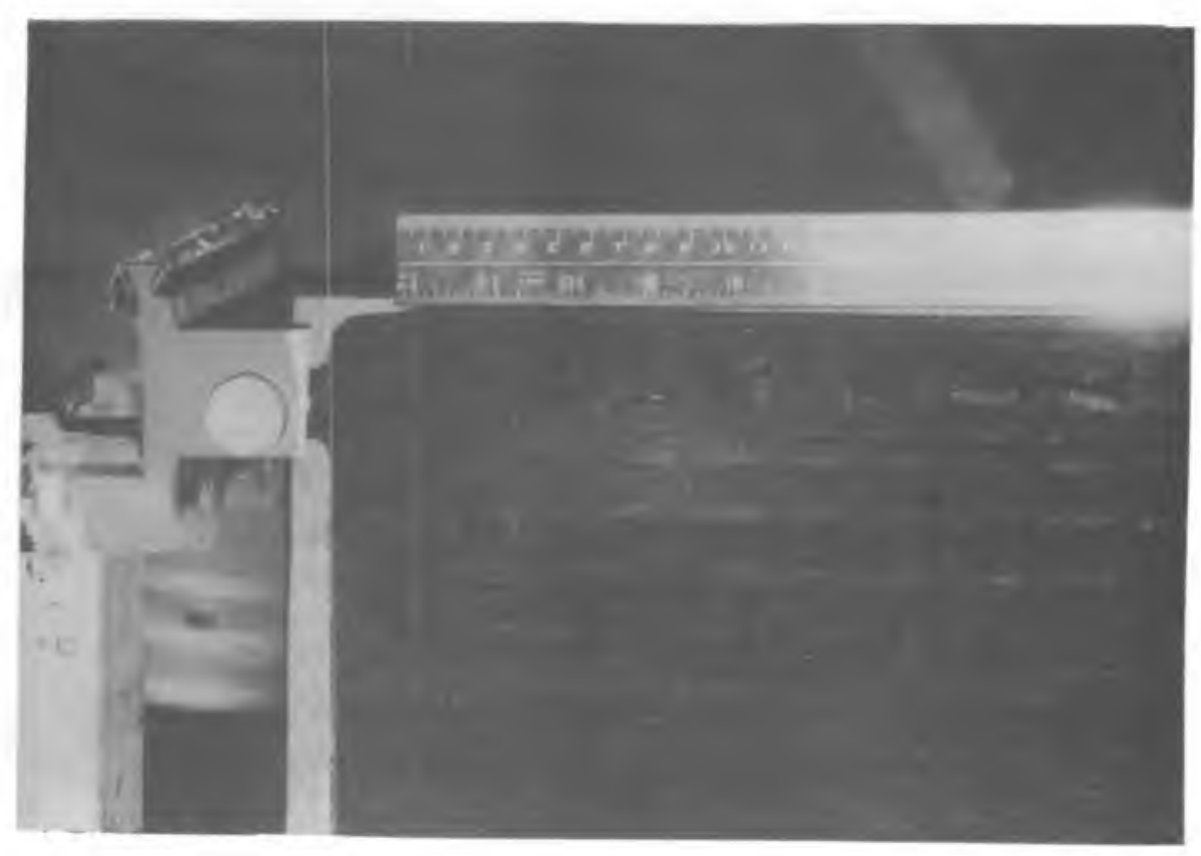

10

B-1 4-

C84- 120 


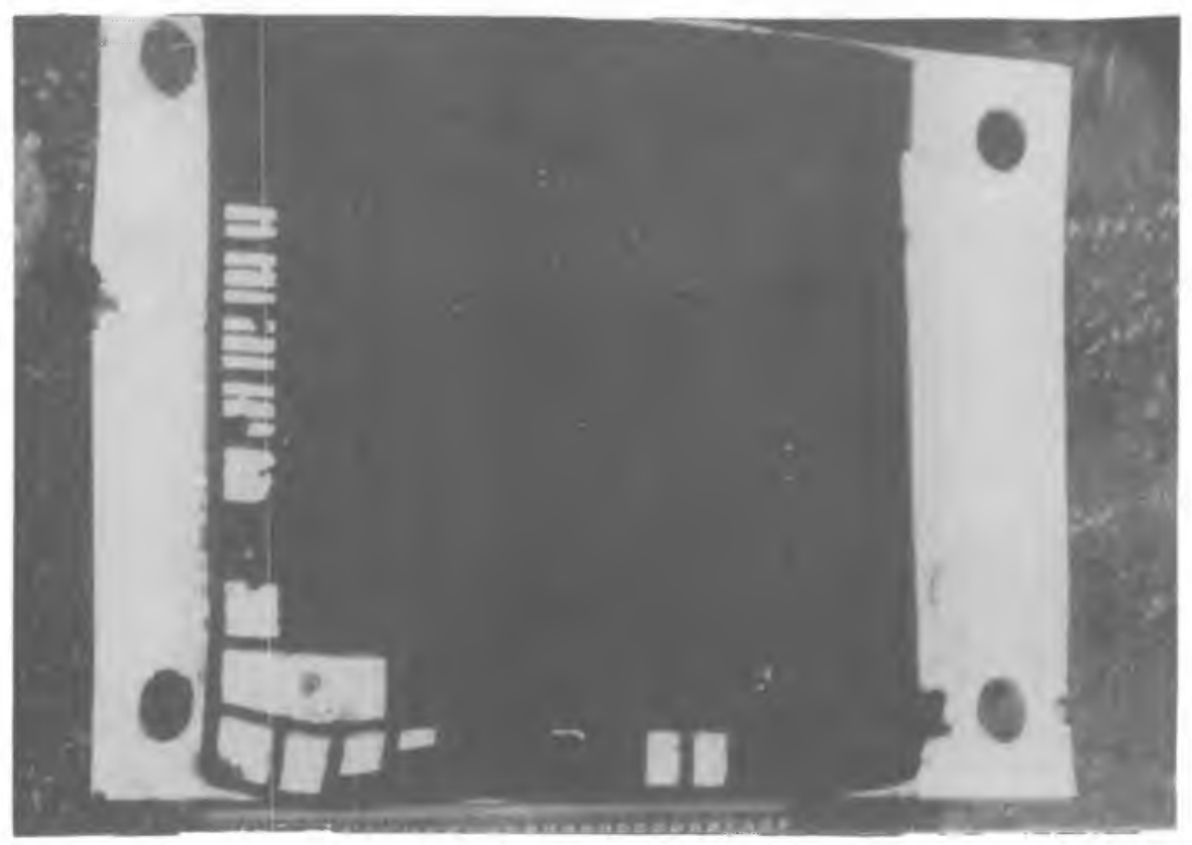

11

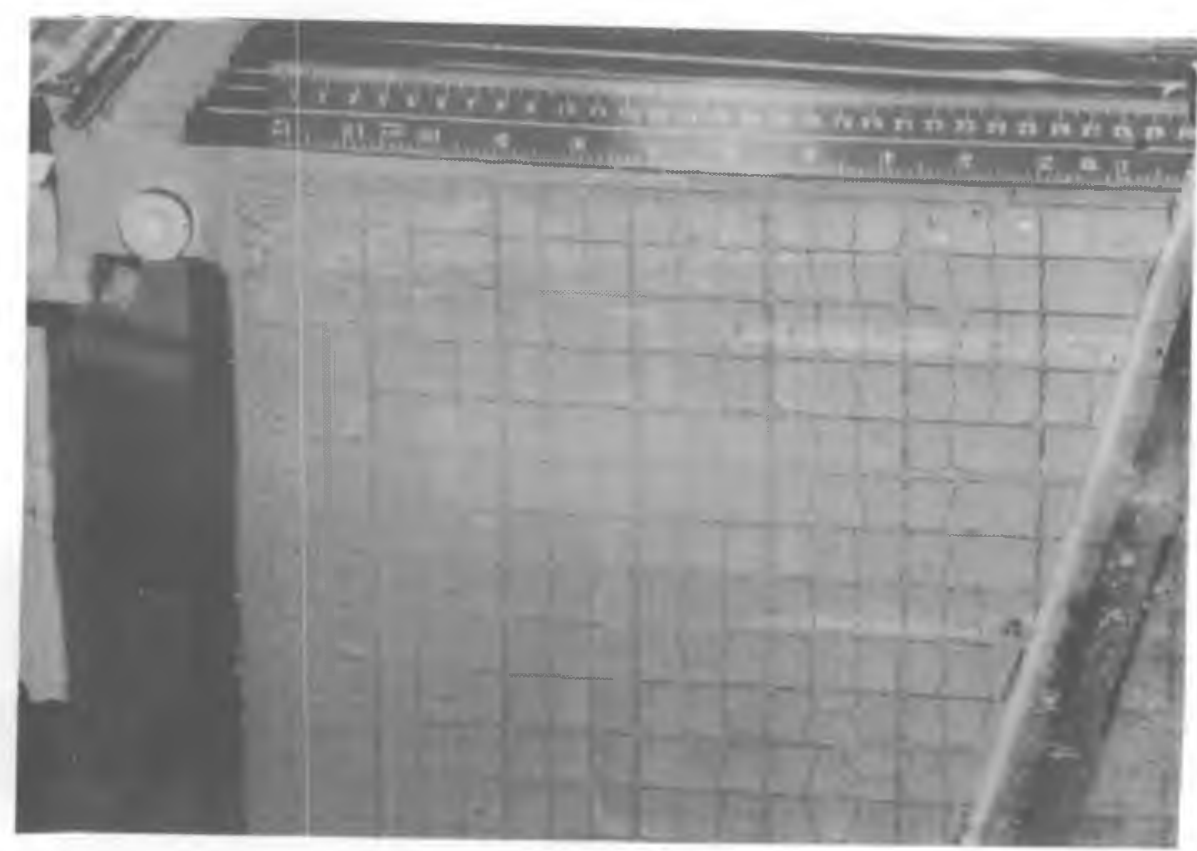

12

B-15- 


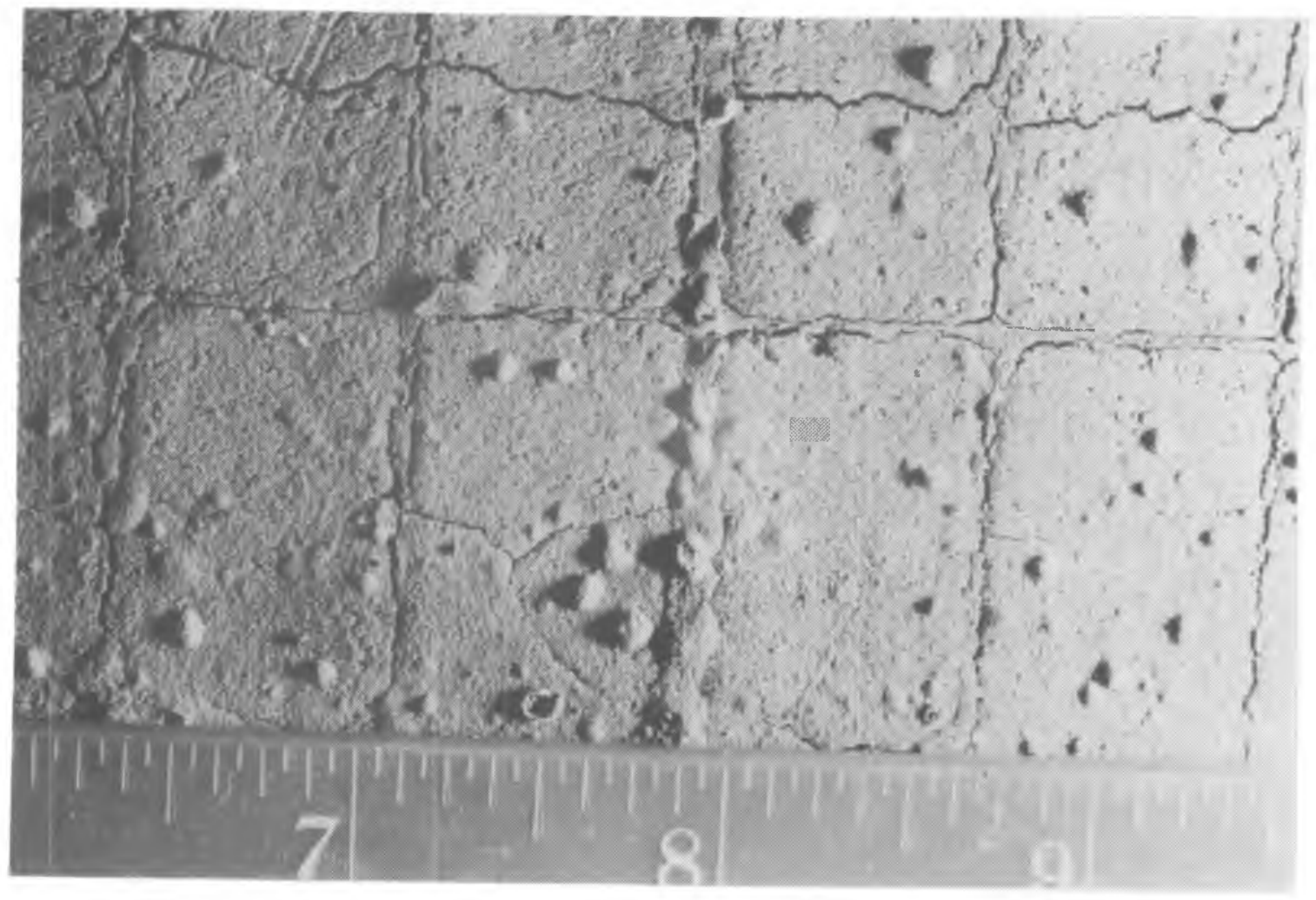

13

B-16-

C $84-120$ 


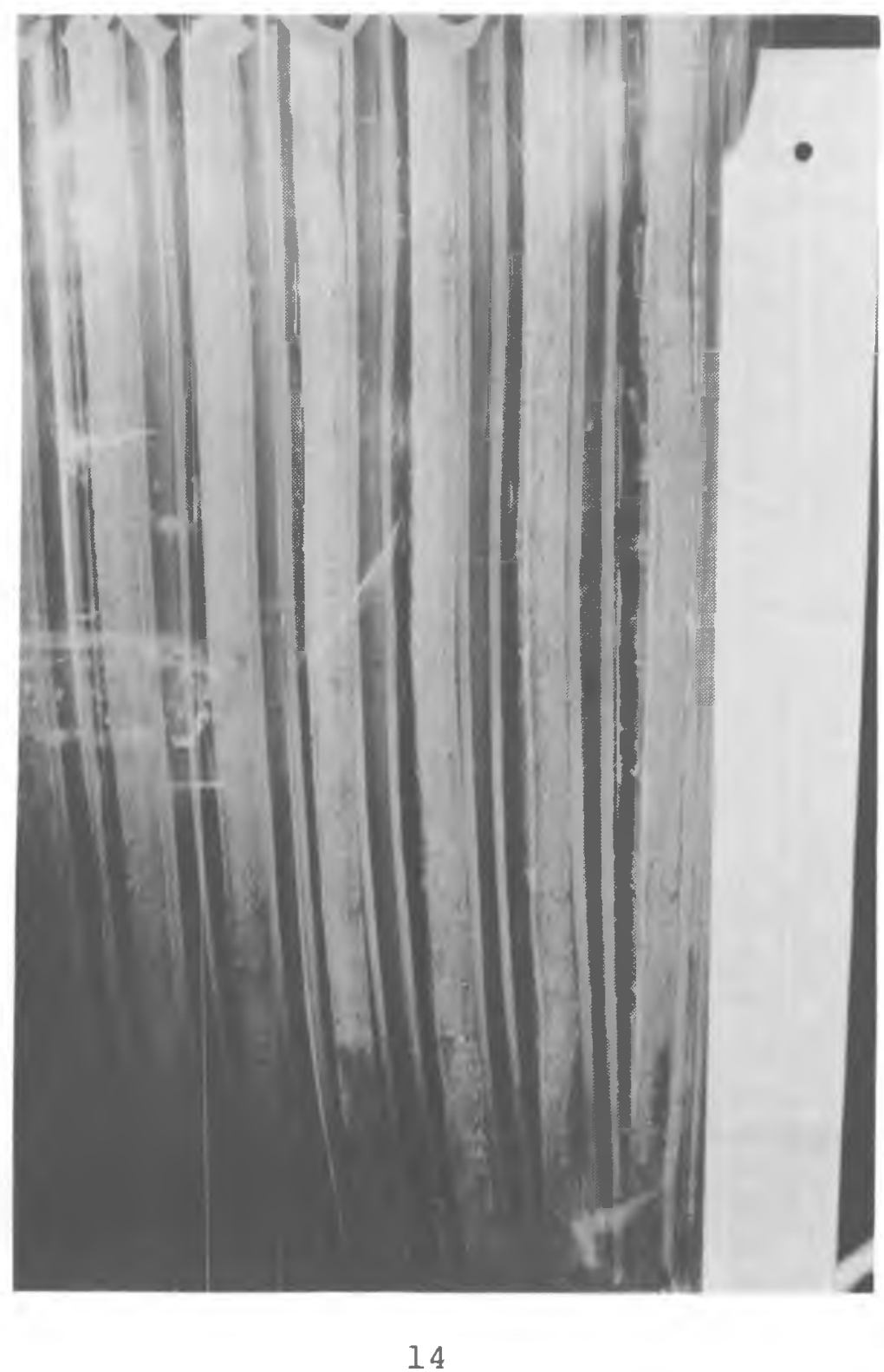

B-17-

C $84-120$ 


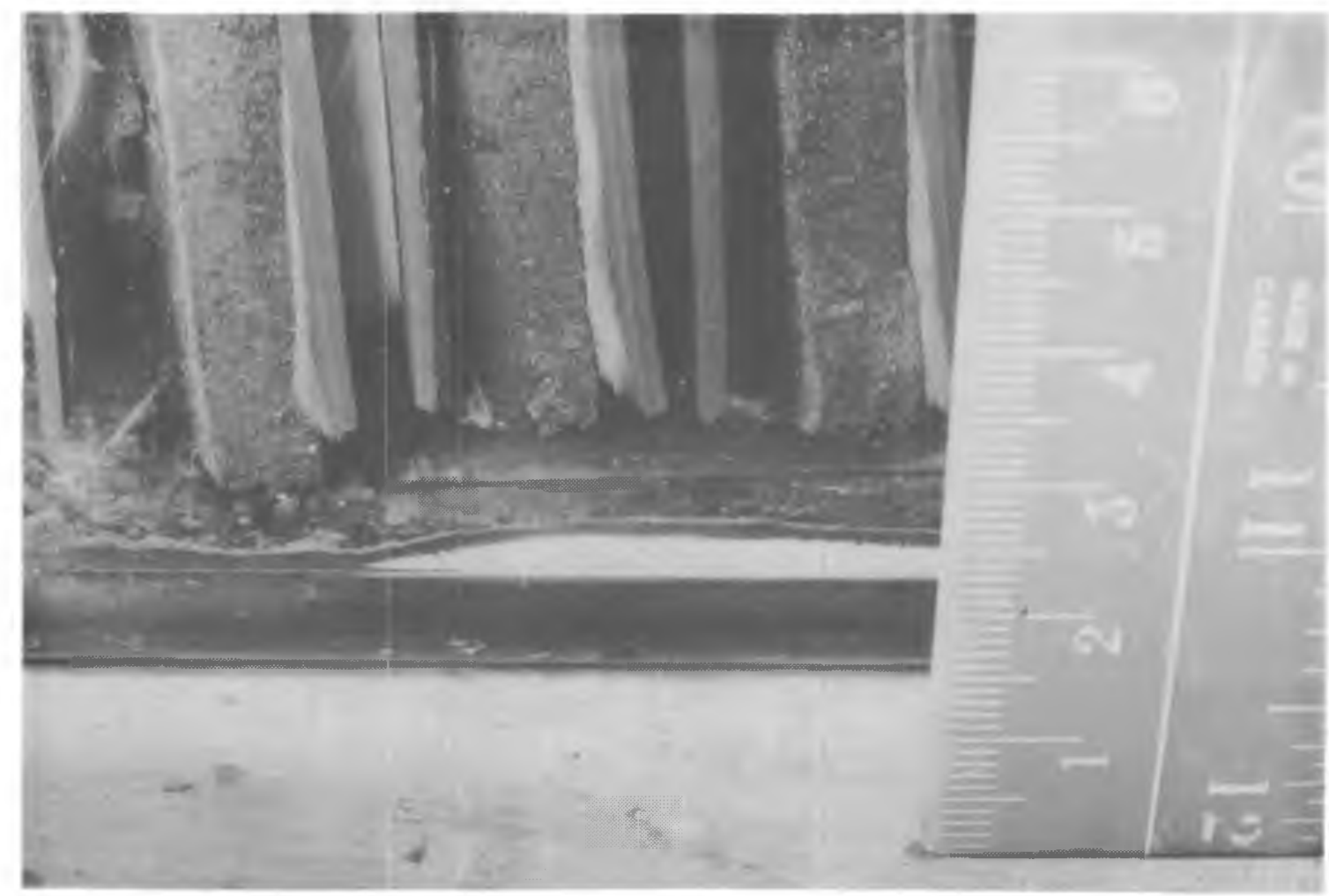

15

3. The inability of cells to meet the acceptance criterion of 808 of rated capacity was primarily due to loss of active material from positive plates. Corroded bus material may have been a contributing factor.

Approved by:

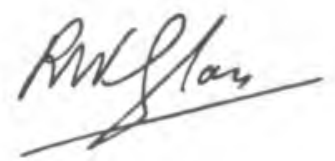

R.W. Glass

Section Head

Organic Section

WJJ : $\mathbf{l g}: \mathbf{k k}$
Prepared by:

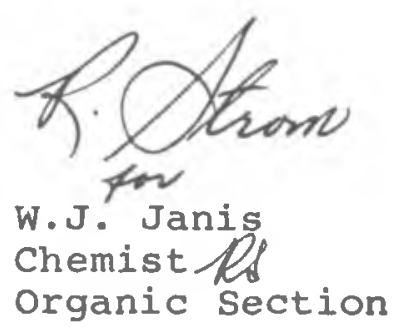




\section{REFERENCES}

1. Bellack, J.H. "IEEE Recommended Practice for Maintenance, Testing and Replacement of Large Lead Storage Batteries for Generating stations and substations". IEEE std 450-1980. October 1980 .

2. Stelter, M.K.G. "Battery Discharge Load for Seismic Tests". Ontario Hydro Research Division Report No E76-85--H. November 1976 .

3. Black, D.A. and G.D. Paulsen, "Seismic Testing of Colvert Cliffs N.P.P. Batteries". Ontario Hydro Research Division Report No 84-418-P.

4. Vinal, G.S. Storage Batteries, Fourth Edition. J. Wiley and Sons, New York (1955). 
TEST CELL SPECIFICATIONS - FHC-19 CELLS

(a) Capacity

\begin{tabular}{|c|c|c|c|c|}
\hline \multicolumn{3}{|c|}{ Discharge Rate to $1.75 \mathrm{~V}$ Per Cell at $25^{\circ} \mathrm{C}$ (Amperes) } \\
\hline For $8 \mathrm{~h}$ & For $5 \mathrm{~h}$ & For $3 \mathrm{~h}$ & For $1.5 \mathrm{~h}$ & For $1 \mathrm{~h}$ \\
\hline 168 & 244 & 354 & 551 & 679 \\
\hline
\end{tabular}

(b) Dimensions

\begin{tabular}{|l|c|c|c|c|}
\hline & Height $(\mathrm{cm})$ & Width $(\mathrm{cm})$ & Length $(\mathrm{cm})$ & Thickness $(\mathrm{cm})$ \\
\hline Overall & 57.7 & 36.8 & 22.9 & -- \\
\hline $\begin{array}{l}\text { Positive } \\
\text { Plate }\end{array}$ & 36.6 & 30.7 & -- & 0.81 \\
\hline $\begin{array}{l}\text { Negative } \\
\text { Plate }\end{array}$ & 36.6 & 30.7 & -- & 0.61 \\
\hline
\end{tabular}


(c) Materials

\begin{tabular}{|c|c|}
\hline Container & $\begin{array}{c}\text { styrene-acrylonitrile copolymer (jar) } \\
\text { styrene butadiene } \\
\text { copolymer (cover) }\end{array}$ \\
\hline Separators & microporous rubber \\
\hline $\begin{array}{l}\text { Positive Plate active } \\
\text { material retainers }\end{array}$ & fiberglass mat \\
\hline Electrodes & $\begin{array}{c}\text { lead-calcium grid (9 positive, } 10 \\
\text { negative, ) }\end{array}$ \\
\hline Posts and busses & $\begin{array}{l}2 \text { positive posts, } 2 \text { negative posts, } \\
2.5 \mathrm{~cm} \times 2.5 \mathrm{~cm} \text { each, attached to } \\
\text { to lead bus. }\end{array}$ \\
\hline Electrolyte & $\begin{array}{c}1.215 \text { specific gravity sulphuric } \\
\text { acid }\left(25^{\circ} \mathrm{C}\right)\end{array}$ \\
\hline
\end{tabular}

1 Note: Busses are sometimes refered to as straps. 
DISCHARGE DATA - SEISMIC EVENT TESTS

\begin{tabular}{|c|c|c|c|c|c|c|}
\hline \multirow[b]{2}{*}{$\begin{array}{c}\text { Cell } \\
\text { Number }\end{array}$} & \multicolumn{3}{|c|}{ Seismic Event Data } & \multicolumn{3}{|c|}{ Cell Potential Data } \\
\hline & $\begin{array}{l}\text { Event } \\
\text { Number }\end{array}$ & $\begin{array}{c}\text { Intensity } \\
\text { Setting }\end{array}$ & $\begin{array}{l}\text { Relative } \\
\text { Start } \\
\text { Time } \\
\text { (s) }\end{array}$ & $\begin{array}{c}\text { At Start } \\
\text { of seismic } \\
\text { Event } \\
\text { (V) }\end{array}$ & $\begin{array}{c}\text { At End } \\
\text { of Sesimic } \\
\text { Event } \\
\text { (V) }\end{array}$ & $\begin{array}{c}\text { Difference } \\
\text { (End-Start) } \\
(\mathrm{mV})\end{array}$ \\
\hline $\begin{array}{c}10 \star \\
15 \\
\text { and } \\
23\end{array}$ & $\begin{array}{l}1 \\
2 \\
3 \\
4\end{array}$ & $\begin{array}{l}4 \\
5 \\
6 \\
7\end{array}$ & $\begin{array}{r}0 \\
77 \\
161 \\
245\end{array}$ & $\begin{array}{l}1.841 \\
1.848 \\
1.850 \\
1.848\end{array}$ & $\begin{array}{l}1.843 \\
1.851 \\
1.850 \\
1.847\end{array}$ & $\begin{array}{r}2 \\
3 \\
0 \\
-1\end{array}$ \\
\hline 15 & $\begin{array}{l}1 \\
2 \\
3 \\
4 \\
5\end{array}$ & $\begin{array}{l}4 \\
5 \\
6 \\
7 \\
7\end{array}$ & $\begin{array}{r}0 \\
42 \\
105 \\
161 \\
266\end{array}$ & $\begin{array}{l}1.864 \\
1.855 \\
1.867 \\
1.869 \\
1.877\end{array}$ & $\begin{array}{l}1.847 \\
1.863 \\
1.869 \\
1.870 \\
1.878\end{array}$ & $\begin{array}{r}-17 \\
8 \\
2 \\
1 \\
1\end{array}$ \\
\hline 35 & $\begin{array}{l}1 \\
2 \\
3 \\
4\end{array}$ & $\begin{array}{l}4 \\
5 \\
6 \\
7\end{array}$ & $\begin{array}{r}0 \\
56 \\
112 \\
182\end{array}$ & $\begin{array}{l}1.860 \\
1.856 \\
1.863 \\
1.865\end{array}$ & $\begin{array}{l}1.842 \\
1.861 \\
1.866 \\
1.866\end{array}$ & $\begin{array}{r}-18 \\
5 \\
3 \\
1\end{array}$ \\
\hline 51 & $\begin{array}{l}1 \\
2 \\
3 \\
4 \\
5\end{array}$ & $\begin{array}{l}4 \\
5 \\
5 \\
6 \\
7\end{array}$ & $\begin{array}{r}0 \\
70 \\
126 \\
189 \\
273\end{array}$ & $\begin{array}{l}1.759 \\
1.814 \\
1.852 \\
1.826 \\
1.829\end{array}$ & $\begin{array}{l}1.789 \\
1.820 \\
1.818 \\
1.826 \\
1.829\end{array}$ & $\begin{array}{r}30 \\
6 \\
-34 \\
0 \\
0\end{array}$ \\
\hline 57 & $\begin{array}{l}1 \\
2 \\
3 \\
4 \\
5\end{array}$ & $\begin{array}{l}3 \\
4 \\
5 \\
6 \\
7\end{array}$ & $\begin{array}{r}0 \\
63 \\
126 \\
175 \\
238\end{array}$ & $\begin{array}{l}1.869 \\
1.848 \\
1.855 \\
1.843 \\
1.843\end{array}$ & $\begin{array}{l}1.834 \\
1.854 \\
1.859 \\
1.854 \\
1.857\end{array}$ & $\begin{array}{r}-35 \\
6 \\
4 \\
11 \\
14\end{array}$ \\
\hline
\end{tabular}

*Multi-cell test (voltages are averages of three cells) 


\section{APPENDIX 2 (cont'd)}

\section{Notes}

1. Seismic test event duration $=30 \mathrm{~s}$ in all cases.

2. The cell failure criterion is a sharp cell potential drop to $<1.75$ VPC.

3. The maximum accelerations for the intensity settings are approximately as follows:

\begin{tabular}{cc}
$\begin{array}{l}\text { Intensity } \\
\text { Setting }\end{array}$ & $\begin{array}{c}\text { Maximum } \\
\text { Acceleration (g) }\end{array}$ \\
\hline 3 & 1.5 \\
4 & 2.0 \\
5 & 2.5 \\
6 & 3.2 \\
7 (machine limit) 3.8
\end{tabular}




\section{APPENDIX 3 \\ DISCHARGE TIME/RATE CALCULATIONS}

Discharge Time at Nominal $1 \mathrm{~h}$

Rate-Converted to Discharge Time

at Nominal $3 \mathrm{~h}$ Rate

The most widely used and accepted equation relating discharge current and time is Peukert's equation/3/:

$$
I^{n_{t}=C}
$$

where $I$ and $t$ are the discharge current and time, respectively, and $\mathrm{n}$ and $\mathrm{C}$ are temperature dependent constants. The constants $\mathrm{n}$ and $\mathrm{C}$ may be evaluated by tests made on any cell or battery at at least two different rates of discharge at constant temperature.

Results of a linear regression analysis of $\log _{e}(t)$ versus $\log _{e}(I)$, using the $I$ and $t$ data of Appendix 1 , are summarized in Table A3.1. An approximate empirical relation for the discharge rate, in amperes, as a function of the discharge time, in hours, is as follows:

$$
I=\left(5.9857 \times 10^{-5} t\right)^{-0.6738}
$$

TABLE A3.1

\begin{tabular}{|c|c|c|c|c|}
\hline$\stackrel{t}{(h)}$ & $\log _{e}(t)$ & $\begin{array}{c}I \\
\text { (amperes) }\end{array}$ & $\log _{e}(I)$ & $\begin{array}{c}\text { Curve Fitting } \\
\text { Parameters }\end{array}$ \\
\hline $\begin{array}{l}8 \\
3 \\
1\end{array}$ & $\begin{array}{c}2.079 \\
1.099 \\
0\end{array}$ & $\begin{array}{l}168 \\
354 \\
679\end{array}$ & $\begin{array}{l}5.124 \\
5.869 \\
6.521\end{array}$ & $\left\{\begin{array}{l}\text { Slope }(-n)=-1.4841 \\
y-\text { intercept }\left(\log _{e}(c)\right)=9.724 \\
\text { Correlation } \\
\text { coefficient }=-0.9974\end{array}\right.$ \\
\hline
\end{tabular}

LINEAR REGRESSION FIT - LOG $(t)$ VERSUS $\operatorname{LOG}_{e}(I)$

From relation [A3.1], discharge currents at different discharge times are related by: 


$$
t_{2}=\left(\frac{I_{1}}{I_{2}}\right)^{n} \cdot t_{1}
$$

where the subscripts refer to different $(I, t)$ pairs.

Equation [A3.3], with $\mathrm{n}=1.4841$, was used to calculate $3 \mathrm{~h}$ rate data using $1 \mathrm{~h}$ rate data, and the results are shown in Table A3.2.

\section{TABLE A3.2}

DISCHARGE TIME CONVERSION ( $1.0 \mathrm{~h}$ RATE TO $3 \mathrm{~h}$ RATE)

\begin{tabular}{|c|c|c|c|c|}
\hline \multirow{2}{*}{$\begin{array}{c}\text { Cell } \\
\text { Number }\end{array}$} & \multicolumn{2}{|c|}{ l h Rate Discharge } & \multicolumn{2}{|c|}{$3 \mathrm{~h}$ Rate Discharge } \\
\cline { 2 - 5 } & $\begin{array}{c}\text { Time } \\
\text { (s) }\end{array}$ & $\begin{array}{c}\text { Current (A) } \\
\text { (nominal) }\end{array}$ & $\begin{array}{c}\text { Time (s) } \\
\text { (calculated) }\end{array}$ & $\begin{array}{c}\text { Current (A) } \\
\text { (nomina1) }\end{array}$ \\
\hline 10 & 310 & 679 & 815 & 354 \\
15 & 625 & 679 & 1643 & 354 \\
23 & 310 & 679 & 815 & 354 \\
35 & 242 & 679 & 636 & 354 \\
51 & 342 & 679 & 899 & 354 \\
57 & 347 & 679 & 912 & 354 \\
\hline
\end{tabular}




\section{APPENDIX 4}

\section{CELL POST-MORTEM INFORMATION}

(a) Observations Common to All Cells

- Negative plate active material cracked horizontally and vertically.

- Numerous 1-3 mm diameter, hollow blisters on the upper quarter of most negative plate.

- Negative active material contracted.

- Separators and retainers intact.

- No plate hanger damage. All plates in proper position.

- Sediment level range: 5-10 mm. Evidence of positive plate active material hard and non-porous.

- Shore hardness of positive active material: $60 \pm 5$.

Reading made with a shore Durometer Hardness Meter, type A-2 as used for American Society for Testing and Materials test D2240-81 for the hardness of rubber materials. Extremely hard plates give a reading of approximately 75 while soft plates give a reading of about 30 . Average plates give a reading of 40 .

(b) $\operatorname{Cel1} 10$

- Positive Plate active material extremely brittle.

- Substantial amount of active material disconnected from grid - wedged between grid and retainers.

- Positive plates swollen slightly in the horizontal direction.

- Positive plate thickness: $0.80 \mathrm{~cm} \pm 0.10 \mathrm{~cm}$.

- Negative plate thickness; $0.50 \mathrm{~cm} \pm 0.10 \mathrm{~cm}$.

- Photos taken: positive plate front view.

(c) $\operatorname{cel1} 15$

- Positive plate active material extensively cracked throughout plate. 
- Photos taken: - bus detail - positive plate.

- bus detail - negative plate.

(d) $\quad$ el1 35

- Positive plate active material extensively cracked throughout plate. Plate swollen slightly.

- Bus material disconnected when hammered.

- Photos taken:

- positive plate front view.

- positive plate hangers.

- negative plate detail showing blisters.

- positive plate detail.

- positive bus detail after several strikes with a hammer.

(e) $\quad \underline{C e 11} 57$

- Positive plate active material cracked slightly - mostly on the perimeter of the plate.

- Majority of positive plate material soft.

- Positive bus fractured after several blows with a hammer material did not fracture easily.

- Photos taken:

- positive bus - typical of all cells - outer view

- negative bus - typical of all cells - outer view

- positive bus - typical of all cells - inner view

- negative bus - typical of all cells - inner view

- negative bus detail

- positive bus detail

- positive bus after several hammer blows. 


\section{APPENDIX C \\ Seismic Testing of North Anna and Calvert Cliffs Nuclear Power station Batteries - second stage - High Table Acceleration}

W. J. Janis

Ontario Hydro Research Division

C-i 
To Mr. B.A. Oliver

Manager

Electrical Design Dept

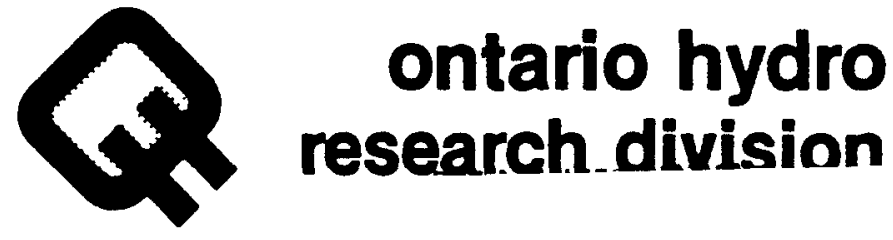

\author{
SEISMIC TESTING OF NORTH ANNA AND CALVERT CLIFFS \\ NUCLEAR POWER STATION BATTERIES - \\ SECOND STAGE - HIGH TABLE ACCELERATION
}

W.J. Janis

\begin{abstract}
The performance and condition $\infty$ FHC-19 and LCU-13 cells previously seismically tested at low shaker table acceleration were monitored before, during and after seismic testing at $85 \%$ and 1008 of maximum table acceleration to determine cell resistance to damage by high seismic stresses. All cells provided uninterrupted power under load, however, post-test capacities averaged only $46 \%$ of expected. Low capacities were due to the effects of previous seismic testing, which caused poor charge acceptance on recharge and also accelerated self-discharge, and violent shaking at high acceleration, which further weakened the cells and increased active material loss.
\end{abstract}

\title{
1.0 INTRODUCTION
}

Sandia National Laboratories (SNL) is currently under contract to the United States Nuclear Regulatory Commission (NRC) to conduct studies on the degradation and failure modes of safety related components used in nuclear power plants. Of particular interest to SNL and NRC, and also to ontario Hydro, is the significance of aging on the seismic-accident survivability of stationary, Class $1 \mathrm{E}$, emergency power batteries.

Because of mutual interest, experience in seismic testing of batteries and the availability of special test facilities, Ontario Hydro was sub-contracted by SNL to carry out seismic fragility tests of naturally aged, lead-acid cells from the North Anna Nuclear Generating Station, Mineral, Virginia and the Calvert Cliffs Nuclear Generating Station, Lusby, Maryland.

\begin{tabular}{|l|r|r|l|}
\hline pob & 823.31 \\
$740632-168-950$ & $\times 836.74$ & March 5, 1985 & C85-19-P \\
\hline
\end{tabular}


Following guidelines set out by SNL, a research program was developed by the Electrical Design Department (Design and Development Division), and the Mechanical and Chemical Research Departments (Research Division). In this program the performance and condition of aged cells were monitiored before, during and after shaker table testing under simulated earthquake conditions.

Studies relating to seismic tests at shaker table zero period accelerations (ZPAs) of about $1.5 \mathrm{~g}$ were described previously in Ontario Hydro Research Division (OHRD) reports $84-426 \mathrm{~K}, 84-425 \mathrm{~K}$, 84-418P, 84-419P, C84-120P and C84-107P/1-6/. From this work it was determined that both FHC-19 and LCU-13 type cells lost, on average, approximately $12-138$ of their 3 hour rate discharge capacity as a result of seismic testing. In addition, FHC-19 cells showed evidence of positive plate active material loss and, on average, could not meet the generally accepted performance requirement of $80 \%$ of rated capacity at the 3 hour rate.

Additional testing at $\mathrm{ZPA}$ levels higher than $1.5 \mathrm{~g}$ was requested by SNI personnel so that test accelerations would encompass predicted levels for the majority of North American nuclear power plant sites. In response to this request, a second stage of testing was performed in which shaker table settings were adjusted to give ZPA levels of approximately $2.0 \mathrm{~g}$. Two FHC-19 cells and two LCU-13 cells previously tested at $1.5 \mathrm{~g}$ ZPA on the shaker table were retested at higher acceleration levels, as discussed in this report.

\subsection{TEST CELLS}

Two Exide Corporation, FHC-19 cells (cells 23 and 51) and two $C \& D$ Corporation, LCU-13 cells (cells 50 and 57) were selected for test from an inventory of 3 LCU-13 and 2 FHC-19 cells remaining after stage 1 seismic testing and cell dissection studies.

The test cells were all of the lead-calcium type, that is the grid material of these cells contained a small amount of calcium, less than 0.18 , alloyed with lead. Cell specifications supplied by the manufacturers are given in Appendix 1.

\subsection{EXPERIMENTAL \\ 3.1 Initial Capacity Tests}

As described in references 5 and 6 , all cells were discharged following stage 1 seismic testing. The cells were discharged to a final cell potential of 1.75 volts per cell (VPC) at the manufacturers' specified 3 hour rates of $246 \mathrm{~A}$ and $359 \mathrm{~A}$ for LCU-13 and FHC-19 cells, respectively. These discharge tests provided benchmark capacity data for the four cells selected for stage 2 
seismic testing and were carried out per reference 7 as follows:

1. Three or four cells and a resistance load were connected in in series and the cells were discharged at a constant current following the procedure outlined in OHRD report No E76-85H/8/.

2. Cell potentials, discharge currents and temperatures were monitored during the discharge test. The data were recorded at 5 min intervals.

3. Discharged cells were recharged in series at a potential of $2.25 \mathrm{~V}$ for $35-70 \mathrm{~h}$, followed by sustained float charging at $2.15 \mathrm{~V}$.

Following capacity testing, the cells were put on floating charge for approximately 90 days. At the end of this period the cells were taken off charge and transferred to the seismic testing laboratory.

\section{2 Cell Discharge During Seismic Testing}

To assess the immediate effect of a high acceleration seismic event on cell performance, cells were kept on discharge during seismic tests and cell voltages and currents were monitored continuously during the stage 2 tests. A $1 \mathrm{~h}$ discharge rate was used for the FHC-19 and LCU-13 cells to simulate emergency conditions.

Discharge was initiated a few seconds prior to the first 30 s seismic event and was continued until the cell either failed during a seismic event or passed the scheduled sequence of seismic events. Failure was defined as the inability of a cell to maintain a potential greater than $1.75 \mathrm{~V}$ while under a constant current discharge at the $I \mathrm{~h}$ rate.

\section{3 Post Seismic Capacity Tests}

After stage 2 seismic testing, all cells were float charged in series at $2.15 \mathrm{VPC}$ for 26 days. This was required to compensate for rapid self-discharge, which took place in two cells, during cell transfers between seismic and chemical testing laboratories. The cells were then discharged in pairs at the $3 \mathrm{~h}$ rate following the same discharge procedure used for the initial capacity tests.

\subsection{RESULTS AND DISCUSSION}

\subsection{Initial Capacity Tests}

Capacity data and pre-test specific gravities and open circuit cell potentials for the test cells prior to stage 2 testing are presented in Table I. Three of four cells met the IEEE recommended acceptance criterion of 80 o rated capacity at the $3 \mathrm{~h}$ rate $/ 7 /$. 
TABLE I

CAPACITY TEST DATA

\begin{tabular}{|c|c|c|c|c|}
\hline $\begin{array}{c}\text { Cell } \\
\text { Number * }\end{array}$ & $\begin{array}{c}25^{\circ} \mathrm{C} \\
\text { Gravity } \\
\text { Prior to } \\
\text { Discharge }\end{array}$ & $\begin{array}{r}\text { Open } \\
\text { Circuit } \\
\text { Potential } \\
\text { (Volts) }\end{array}$ & $\begin{array}{c}\text { Time to } \\
1.75 \text { VPC at } \\
\text { rate } \\
\text { (min) } * *\end{array}$ & $\begin{array}{c}\text { Percent of } \\
\text { Rated } \\
\text { Capacity at } \\
\text { h Rate *** }\end{array}$ \\
\hline 23 & 1.205 & 2.02 & 135 & 75 \\
50 & 1.210 & 2.06 & 168 & 93 \\
51 & 1.205 & 2.04 & 177 & 98 \\
57 & 1.210 & 2.04 & 176 & 98 \\
\hline
\end{tabular}

* Cells 23 and 51 are FHC-19 cells, cells 50 and 57 are LCU-13.

** The $3 \mathrm{~h}$ rates for FHC-19 and LCU-13 cells are 359A and 246A, respectively.

*** Capacity includes a contribution due to discharge during stage 1 seismic tests. Calculation of this contribution is detailed in references 5 and 6 .

After initial capacity tests, the cells were recharged at 2.15 VPC. After approximately 90 days of float charging the cell specific gravities of all cells were between 1.200 and 1.230 and both open circuit voltages and charging current had stabilized. (Approximately 2.1 V and 10 A per cell, respectively.) Following Appendix B of IEEE Standard $450 / 7 /$, stabilization of the voltage-regulated charging current at the charging voltage of 2.15 VPC was taken as an indication that the cells in question were charged. The cells were therefore taken off charge and transferred to the Mechanical Research Facility for testing.

The test cells were off charge for approximately 5 days during transfer and setup operations. During this period an unexpected drop in the specific gravities of LCU-13 cell 57 and FHC-19 cell 23 was noted and attributed to rapid self-discharge. Specific gravities and open circuit potentials before and after transfer are presented in Table II.

The data in Table II indicate abnormal behaviour for cells 23 and 57 during the relatively short period these cells were off charge. 
TABIE II

SELF-DISCHARGE DATA

\begin{tabular}{|c|c|c|c|c|}
\hline \multirow{2}{*}{ CELL } & \multicolumn{2}{|c|}{$25^{\circ} \mathrm{C}$ Gravity } & \multicolumn{2}{c|}{ Open Circuit Potential (V) } \\
\cline { 2 - 5 } & $\begin{array}{c}\text { Prior to Cell } \\
\text { Transfer }\end{array}$ & $\begin{array}{c}5 \text { Days After } \\
\text { Cell Transfer }\end{array}$ & $\begin{array}{c}\text { Prior to Cell } \\
\text { Transfer }\end{array}$ & $\begin{array}{c}5 \text { Days After } \\
\text { Cell Transfer }\end{array}$ \\
\hline & & & & \\
23 & 1.207 & 1.168 & 2.05 & 2.02 \\
50 & 1.210 & 1.205 & 2.06 & 2.07 \\
51 & 1.225 & 1.222 & 2.06 & 2.06 \\
\hline 57 & 1.207 & 1.170 & & 2.06 \\
\hline
\end{tabular}

\subsection{Cell Discharge During Seismic Testing}

No sudden loss of cell potential was observed for any cells during seismic testing. The pass/fail results are sumarized in Table III and presented in more detail in Appendix 2. Details of the seismic testing procedure and fragility level assessment are presented in OHRD reports $85-55 \mathrm{P}$ and $85-56 \mathrm{P} / 9,10 /$.

TABLE III

DISCHARGE DATA SUMMARY - SEISMIC EVENT TESTS

\begin{tabular}{|c|c|c|c|c|}
\hline \multirow{2}{*}{$\begin{array}{c}\text { Cell } \\
\text { Number }\end{array}$} & $\begin{array}{l}\text { Pass/Fail } \\
\text { at 1 h } \\
\text { Discharge } \\
\text { Rate* }\end{array}$ & \multicolumn{2}{|c|}{$\begin{array}{c}\text { Cell Potential While } \\
\text { Under Load (V) }\end{array}$} & $\begin{array}{c}\text { Total Time } \\
\text { on } \\
\text { Discharge } \\
\text { (s) }\end{array}$ \\
\cline { 2 - 5 } & $\begin{array}{c}\text { Before } \\
\text { Testing }\end{array}$ & $\begin{array}{c}\text { After } \\
\text { Testing }\end{array}$ & $\begin{array}{c}\text { Desting } \\
23\end{array}$ \\
50 & Fail & 1.71 & 1.69 & 60 \\
51 & Pass & 1.82 & 1.84 & 84 \\
57 & Pass & 1.83 & 1.85 & 70 \\
\hline
\end{tabular}

* Discharge rate is 679A for FHC-19 cells and $480 \mathrm{~A}$ for LCU-13 cells.

FHC-19 cell 23 had a cell potential under load of less than the required $1.75 \mathrm{~V}$ during seismic testing and therefore must be designated as a failed cell. However, this cell had low electrical 
potential prior to seismic testing as a result of self-discharge and the low cell potential observed was not caused by the second stage seismic events. The fact that the cell potential held relatively constant during the seismic event series indicates that cell 23 did not suffer a catastrophic failure while under load it could still deliver usable power after stage 2 seismic testing.

FHC-19 cell 51 and LCU-13 cells 50 and 57 survived stresses up to the stage 2 capacity of the shaker table test equipment and delivered uninterrupted power at cell potentials in excess of the $1.75 \mathrm{~V}$ requirement.

\subsection{Post-Seismic Recharge and Capacity Tests}

Post-seismic test discharge capacities were determined for all cells after an extended period of float charging at 2.15 VPC. Float charging and capacity test data are presented in Table IV.

TABIE IV

POST-TEST CAPACITY DATA

\begin{tabular}{|c|l|c|c|c|}
\hline $\begin{array}{c}\text { Cell } \\
\text { Number * }\end{array}$ & $\begin{array}{c}25^{\circ} \mathrm{C} \\
\text { Gravity } \\
\text { Prior to } \\
\text { Discharge }\end{array}$ & $\begin{array}{c}\text { Open } \\
\text { Potential } \\
\text { (Volts) }\end{array}$ & $\begin{array}{c}\text { Time to } \\
1.75 \text { vP at } \\
3 \text { rate } \\
\text { (min) }\end{array}$ & $\begin{array}{c}\text { Percent of } \\
\text { Rated } \\
\text { Capacity at } \\
3 \text { h Rate }\end{array}$ \\
\hline 23 & 1.188 & 2.04 & 60 & 33 \\
50 & 1.208 & 2.08 & 921 & 67 \\
51 & 1.228 & 2.09 & 95 & 31 \\
57 & 1.173 & 2.01 & 55 & 53 \\
\hline
\end{tabular}

* Cells 23 and 51 are FHC-19 cells, cells 50 and 57 are LCU-13.

** The $3 \mathrm{~h}$ rates for FHC-19 and LCU-13 cells are 359A and 246A, respectively.

The specific gravity data in Table IV for cells 23 and 57 indicate poor charge acceptance by these cells during float charging. As a result, the discharge capacities for these cells were extremely low. Cells 50 and 51 had acceptable specific gravities prior to discharge and therefore higher discharge capacities than the other cells. However, no cell tested could meet the acceptance criterion of $80 \%$, or greater, of rated $3 \mathrm{~h}$ capacity. 
A discharge capacity summary for the test cells over the course of stage 1 ( $1.5 \mathrm{~g} \mathrm{ZPA})$ and stage 2 ( $2 \mathrm{~g} \mathrm{ZPA})$ testing is presented as Table $V$. The Table $V$ data indicate a significant loss of discharge capacity for all cells as a result of the two stages of seismic testing.

TABLE V

CELI CAPACITY SUMMARY - SEISMIC

TESTING STAGES 1 AND 2

\begin{tabular}{|c|c|c|c|}
\hline \multirow[t]{2}{*}{$\operatorname{Cell}$} & \multicolumn{3}{|c|}{ Percent of Rated Capacity at $3 \mathrm{~h}$ Rate } \\
\hline & Pre-seismic & $\begin{array}{l}\text { Post-seismic } \\
\text { (Stage I) }\end{array}$ & $\begin{array}{c}\text { Post-seismic } \\
(\text { Stage } 2)\end{array}$ \\
\hline $\begin{array}{l}23 \\
50 \\
51 \\
57\end{array}$ & $\begin{array}{l}86 \\
107 \\
94 \\
107\end{array}$ & $\begin{array}{l}75 \\
89 \\
98 \\
91\end{array}$ & $\begin{array}{l}33 \\
67 \\
53 \\
31\end{array}$ \\
\hline AVG & 99 & 88 & 46 \\
\hline
\end{tabular}

\subsection{CONCLUSIONS}

1. Both ICU-13 cells and one of two FHC-19 cells selected for seismic testing at high shaker table acceleration provided uninterrupted power at required electrical potential under load during repeated and violent shaking. One FHC-19 cell failed to achieve an acceptable cell potential while under load due to an abnormally low initial state of charge, however the cell provided constant power during shaker tests.

2. FHC-19 cell 23 and LCU-13 cell 57 showed evidence of a high rate of self-discharge as a result of previous (stage 1 ) seismic testing at zero period accelerations of $1.5 \mathrm{~g}$.

3. After stage 2 seismic testing cells 23 and 57. exhibited 
poor charge acceptance on recharge at 1.15 VPC.

4. No seismically tested cells could meet the acceptance criterion of $80 \%$ of rated $3 \mathrm{~h}$ capacity after the stage 2 seismic tests.

5. Although naturally aged FHC-19 or LCU-13 cells may provide acceptable power at 1.75 VPC or more during repeated and violent shaking, and also demonstrate adequate capacity immediately following a series of seismic events, damage sustained during seismic events may cause excessively high self-discharge and/or prevent cell recharging.

6. RECOMMENDATION

Celis currently under test as part of contract number 96-9358 "Sandia Battery Test Program - Accelerated Aging" should undergo duplicate discharge tests after seismic testing to evaluate cell charge acceptance. After the duplicate tests, the specific gravities of the cells should be monitored for 2 weeks while the cells are disconnected from a charging source to determine the rate of cell self-discharge.

Approved by:

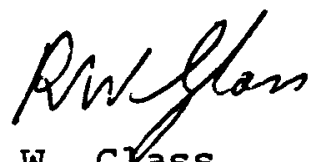

R.W. Glass

Section Head

Organic Research Section
Prepared by:

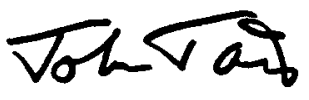

W.J. Jani

Chemist LA.

Organic Research Section 


\section{REFERENCES}

1. Tulk, J.D., et al,"Seismic Testing of Naturally Aged Exide FHC-19 Station Battery Cells", Ontario Hydro Research Division Report $84-426 \mathrm{~K}^{-}$, (December, 1984).

2. Tulk, J.D., et al,"Seismic Testing of Aged, C\&D LCU-13 Station Battery Cells", Ontario Hydro Research Division Report 84-425K , (December, 1984).

3. Black, D.A., and G.D. Paulsen,"Seismic Testing of Calvert Cliffs NPP Batteries", Ontario Hydro Research Division Report 84-418P, (December, 1984).

4. Black, D.A., and G.D. Paulsen, "Seismic Testing of North Anna Nuclear Power Plant Batteries",Ontario Hydro Research Division Report 84-419P, (December, 1984).

5. Janis, W.J.,"Seismic Testing of Calvert Cliffs Nuclear Power Station Batteries - Cell Inspection and Capacity Tests", Ontario Hydro Research Division Report C84-120P (December, 1984).

6. Janis, W.J.,"Seismic Testing of North Anna Nuclear Power Station Batteries - Cell Inspection and Capacity Tests", Ontario Hydro Research Division Report C84-107P (December, 1984).

7. Bellack, J.H., "IEEE Recommended Practice for Maintenance, Testing and Replacement of Large Lead Storage Batteries for Generating Stations and Substations", IEEE Std 450-1980, (October,1980).

8. Stelter, M.K.G., "Battery Discharge Load for Seismic Tests", Ontario Hydro Research Division Report E76-85H, (November,1976).

9. Black, D.A. and G.D. Paulsen, "Seismic Re-test of North Anna Nuclear Power Station Batteries at Increased Acceleration", Ontario Hydro Research Division Report 85-55P, (February, 1985).

10. Black, D.A. and G.D. Paulsen, "Seismic Re-test of Calvert Cliffs Nuclear Power Station Batteries at Increased Acceleration", Ontario Hydro Research Division Report 85-56P, (February, 1985). 
(a) Capacity

\begin{tabular}{|c|c|c|c|c|}
\hline \multicolumn{2}{|c|}{ Discharge Rate to $1.75 \mathrm{~V}$ Per Cell at $25^{\circ} \mathrm{C}$ (Amperes) } \\
\hline For $8 \mathrm{~h}$ & For $5 \mathrm{~h}$ & For $3 \mathrm{~h}$ & For $1.5 \mathrm{~h}$ & For $1 \mathrm{~h}$ \\
\hline 168 & 244 & 354 & 551 & 679 \\
\hline
\end{tabular}

(b) Dimensions

\begin{tabular}{|l|c|c|c|c|}
\hline & Height $(\mathrm{cm})$ & Width $(\mathrm{cm})$ & Length $(\mathrm{cm})$ & Thickness (cm) \\
\hline Overall & 57.7 & 36.8 & 22.9 & -- \\
\hline $\begin{array}{l}\text { Positive } \\
\text { Plate }\end{array}$ & 36.6 & 30.7 & -- & 0.81 \\
\hline $\begin{array}{l}\text { Negative } \\
\text { Plate }\end{array}$ & 36.6 & 30.7 & -- & 0.61 \\
\hline
\end{tabular}

\section{(c) Materials}

\begin{tabular}{|c|c|}
\hline Container & $\begin{array}{c}\text { styrene-acrylonitrile copolymer (jar) } \\
\text { styrene butadiene } \\
\text { copolymer (cover) }\end{array}$ \\
\hline Separators & microporous rubber \\
\hline $\begin{array}{l}\text { Positive Plate active } \\
\text { material retainers }\end{array}$ & fiberglass mat \\
\hline Electrodes & $\begin{array}{c}\text { lead-calcium grid ( } 9 \text { positive, } 10 \\
\text { negative, })\end{array}$ \\
\hline Posts and buses & $\begin{array}{l}2 \text { positive posts, } 2 \text { negative posts, } \\
2.5 \mathrm{~cm} \times 2.5 \mathrm{~cm} \text { each, attached to } \\
\text { to lead bus. }\end{array}$ \\
\hline Electrolyte & $\begin{array}{c}1.215 \text { specific gravity sulphuric } \\
\text { acid }\left(25^{\circ} \mathrm{C}\right)\end{array}$ \\
\hline
\end{tabular}

1 Note: Buses are sometimes refered to as straps.

$$
\text { C-10- C?5-19 }
$$




\section{APPENDIX 1 (Continued) \\ TEST CELL SPECIFICATIONS - LCU-13 CELLS}

\section{(a) Capacity}

\begin{tabular}{|c|c|c|c|c|}
\hline \multicolumn{3}{|c|}{ Discharge Rate to $1.75 \mathrm{~V}$ Per Cell at $25^{\circ} \mathrm{C}$ (Amperes) } \\
\hline For $8 \mathrm{~h}$ & For $5 \mathrm{~h} *$ & For $3 \mathrm{~h}$ & For $1.5 \mathrm{~h}$ & For $1 \mathrm{~h}$ \\
\hline 112 & 161 & 246 & 374 & 480 \\
\hline
\end{tabular}

* As calculated in Appendix 3 of Reference 6 from manufacturer's data.

(b) Dimensions

\begin{tabular}{|l|c|c|c|c|}
\hline & Height (cm) & Width (cm) & Length (cm) & Thickness (cm) \\
\hline Overall & 57.5 & 35.9 & 19.4 & -- \\
\hline $\begin{array}{l}\text { Positive } \\
\text { Plate }\end{array}$ & 38.1 & 30.5 & -- & 0.79 \\
\hline $\begin{array}{l}\text { Negative } \\
\text { Plate }\end{array}$ & 38.1 & 30.5 & -- & $\begin{array}{l}0.53^{*} \\
0.33^{\star}\end{array}$ \\
\hline
\end{tabular}

* Inside negative

* Outside negative 
(c) Materials

\begin{tabular}{|c|c|}
\hline Container & $\begin{array}{c}\text { Transparent Polycarbonate Case } \\
\text { Opaque Thermoplastic Cover }\end{array}$ \\
\hline Separators & unspecified microporous material \\
\hline $\begin{array}{l}\text { Positive Plate active } \\
\text { material retainers }\end{array}$ & fiberglass mat \\
\hline Electrodes & $\begin{array}{c}\text { lead-calcium grid ( } 6 \text { positive, } \\
7 \text { negative) }\end{array}$ \\
\hline Posts and Buses & $\begin{array}{l}2 \text { positive posts, } 2 \text { negative posts, } \\
2.5 \mathrm{~cm} \times 2.5 \mathrm{~cm} \text { each, attached to } \\
\text { to lead bus. }\end{array}$ \\
\hline Electrolyte & $\begin{array}{c}1.210 \text { specific gravity sulphuric } \\
\text { acid }\left(25^{\circ} \mathrm{C}\right)\end{array}$ \\
\hline
\end{tabular}

1 Note: Buses are sometimes refered to as straps. 
APPENDIX 2

DISCHARGE DATA - SEISMIC EVENT TESTS

\begin{tabular}{|c|c|c|c|c|c|c|}
\hline \multirow[b]{2}{*}{$\begin{array}{c}\mathrm{Cell} \\
\text { Number }\end{array}$} & \multicolumn{3}{|c|}{ Seismic Event Data } & \multicolumn{3}{|c|}{ Cell Potential Data } \\
\hline & $\begin{array}{l}\text { Event } \\
\text { Number }\end{array}$ & $\begin{array}{l}\text { Intensity } \\
\text { Setting } \\
\text { ( } 8 \text { of Table } \\
\text { Maximum) }\end{array}$ & $\begin{array}{l}\text { Relative } \\
\text { Start } \\
\text { Time } \\
\text { (s) }\end{array}$ & $\begin{array}{l}\text { At Start } \\
\text { of } \\
\text { Seismic } \\
\text { Event }\end{array}$ & $\begin{array}{l}\text { At End } \\
\text { of } \\
\text { Seismic } \\
\text { Event }\end{array}$ & $\begin{array}{c}\text { Difference } \\
\text { (End - } \\
\text { Start) } \\
\text { (mV) }\end{array}$ \\
\hline $\begin{array}{l}23 \\
23\end{array}$ & $\frac{1}{2}$ & $\begin{array}{l}85 \\
100\end{array}$ & $\begin{array}{l}0 \\
30\end{array}$ & $\begin{array}{l}1.707 \\
1.672\end{array}$ & $\begin{array}{l}1.670 \\
1.686\end{array}$ & $\begin{array}{r}37 \\
14\end{array}$ \\
\hline $\begin{array}{l}50 \\
50\end{array}$ & $\begin{array}{l}1 \\
2\end{array}$ & $\begin{array}{l}85 \\
100\end{array}$ & $\begin{array}{l}0 \\
49\end{array}$ & $\begin{array}{l}1.834 \\
1.836\end{array}$ & $\begin{array}{l}1.828 \\
1.835\end{array}$ & $\begin{array}{l}-6 \\
-\quad 1\end{array}$ \\
\hline $\begin{array}{l}51 \\
51\end{array}$ & $\begin{array}{l}1 \\
2\end{array}$ & $\begin{array}{l}85 \\
100\end{array}$ & $\begin{array}{l}0 \\
35\end{array}$ & $\begin{array}{l}1.833 \\
1.838\end{array}$ & $\begin{array}{l}1.828 \\
1.853\end{array}$ & $\begin{array}{r}5 \\
15\end{array}$ \\
\hline $\begin{array}{l}57 \\
57\end{array}$ & $\begin{array}{l}1 \\
2\end{array}$ & $\begin{array}{l}85 \\
100\end{array}$ & $\begin{array}{l}0 \\
35\end{array}$ & $\begin{array}{l}1.780 \\
1.776\end{array}$ & $\begin{array}{l}1.783 \\
1.776\end{array}$ & $\begin{array}{l}3 \\
0\end{array}$ \\
\hline
\end{tabular}

Notes

1. Seismic test event duration $=30 \mathrm{~s}$ in all cases.

2. The relative start time zero is coincident with the initiation of the first $30 \mathrm{~s}$ seismic event.

3. The cell failure criterion is a sharp cell potential drop to 1.75 VPC or less.

4. Zero Period Acceleration at 1008 table maximum $=2 \mathrm{~g}$, approximately. 


\section{APPENDIX D}

Seismic Testing of

Calvert Cliffs N. P. P. Batteries

D. A. Black

G. D. Paulsen

Ontario Hydro Research Division

$D-i$ 
To Mr. B.A. Oliver

Manager

Electrical Design

Design \& Development

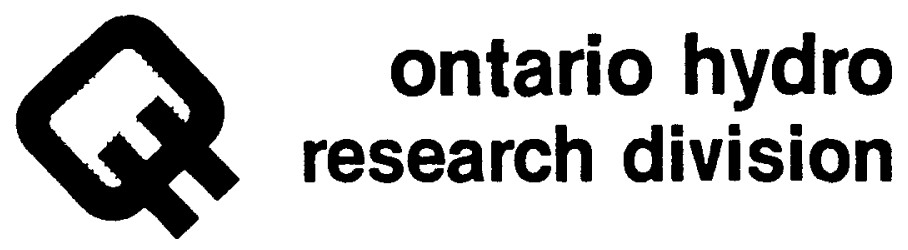

\author{
SEISMIC TESTING OF \\ CALVERT CLIFFS N.P.P. BATTERIES \\ D.A. Black and G.D. Paulsen
}

Six naturally aged back-up battery cells removed from the Calvert Cliffs N.P.P. were seismically tested to IEEE Specifications. This report describes the test procedure followed, the test equipment used, and gives the results of the tests.

\title{
1.0 INTRODUCTION
}

Six used station battery cells from Calvert Cliffs Nuclear Power Plant were seismically tested on a tri-axial shaker table. Three were tested in a battery rack while four were mounted in a rigid frame and tested individually. The cells were tested to meet IEEE 344/1/ and IEEE 501/2/ Specifications. Date of test, specimen description, test facility name and location, test data and test temperature, humidity and pressure are recorded on each of the response spectrum curves. These curves also show the conditions of the test, the type of analysis, the accelerometers used, the direction of the test, and the axis analysed. All tests were analysed using 58 damping and the maximax shock spectrum. The tests performed were tri-axial tests as defined in IEEE 344 . Shaker inputs were pseudo-random with a duration of $30 \mathrm{~s}$. All technical terms used in this report are defined by Harris/3/.

\subsection{SAMPLES}

The cells submitted for testing were naturally aged for a period of 10 years. They were identified as follows:

Station Cell; Exide; Model FHC-19; Serial No 57, 15, 51, 35, 23, 10 .

\begin{tabular}{|c|c|c|c|c|}
\hline job & $740624-268-450$ & 824.46 & date December 11,1984 & $\begin{array}{r}\text { report no. } \\
84-418-P\end{array}$ \\
\hline
\end{tabular}




\subsection{TEST EQUIPMENT}

\subsection{Eguipment Used}

\subsubsection{Shaker Control Equipment}

1. MTS 436 control units

2. MTS 406.11 controllers

3 MTS hydraulic pumps

4. Ontario. Hydro noise generators and filters

5. Ontario Hydro tri-axial shaker table.

\subsubsection{Analysis}

1. Columbia Model 9000 amplifiers and matching Wilcoxon M-408 accelerometers.

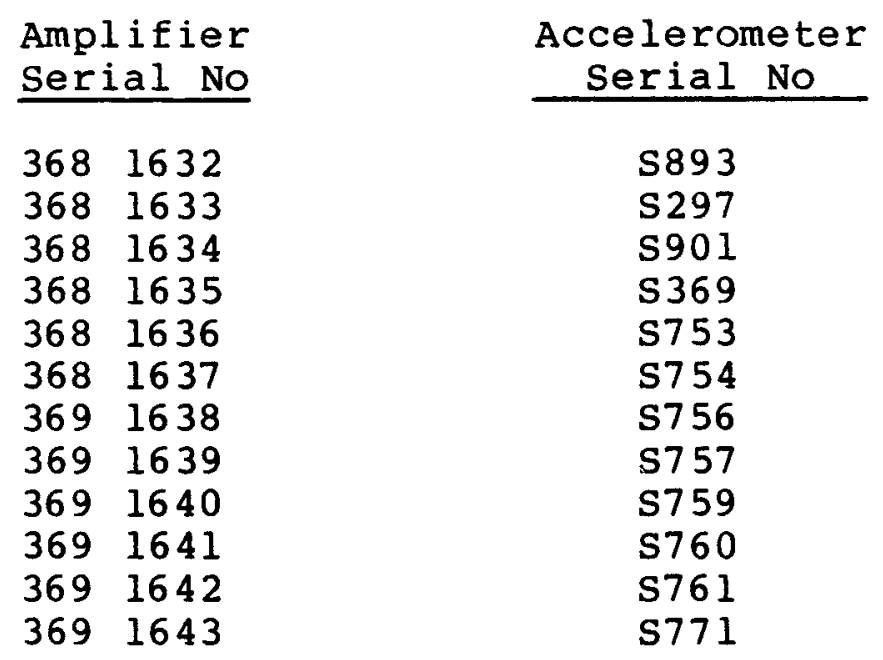

2. SE tape recorder Model 7000A, Serial No 547.

3. Tektronix 5113 dual beam storage oscilloscope, KS3681.

4. Spectral Dynamics 13231 Shock Spectrum Analyser, Serial No 27.

5. Spectral Dynamics 13191 Transient Memory, Serial No 29.

6. Ontario Hydro transmissibility circuit.

7. Watanabe WX4400 X-Y Recorder, Serial No 83010070.

8. Hewlett-Packard 7046A X-Y1-Y2 Recorder, Serial No 1.914 A0 5842 .

9. Spectral Dynamics 50121L Tracking Filter, Serial No 171. 
10. Spectral Dynamics SD122L Tracking Filter, Serial No 370 .

11. Honeywell 1858 oscillograph, Serial No $2649 \mathrm{JF} 78$.

12. Nicolet Scientific Corp, Model $660 \mathrm{~A}$ Dual Channel FFT Analyzer, Serial No 9866226.

13. Hewlett-Packard Model 7470A Plotter, Serial No $2210 A-12990$.

3.1.3 Calibration Equipment

1. Bruel and $\mathrm{kjaer}$ Type 3506 , Serial No 877022 Accelerometer Calibration Set which includes Type 2626 , Serial No 842947 and Type 83055, Serial No 858627, traceable to NBS.

2. General Radio 1557-A vibration calibrator, Serial No 2379 .

3. Data Precision 2440 digital voltmeter, Serial No 5733 , traceable to NBS.

4. Data Precision 248 digital voltmeter, Serial No 8583 , traceable to NBS.

\subsection{TESTS AND PROCEDURES}

\subsection{Calibration Procedure}

Accelerometers and amplifiers are calibrated using the back-toback calibration procedure. The reference accelerometer was mounted on the vibration calibrator with the Wilcoxon accelerometer. Using $100 \mathrm{~Hz}$ sine wave vibration of approximately $1 \mathrm{~g}$, the sensitivity of the Columbia amplifiers was set to give 500 $\mathrm{mV} / \mathrm{g}$ output. The outputs were measured using the digital voltmeter. By using the same voltmeter for both the reference and the Columbia amplifiers, slight differences in voltmeters need not be considered. Since the voltmeter measures true RMS voltages, the waveshapes of the $100 \mathrm{~Hz}$ signals were compared on the oscilloscope. This ensures that the signals are equivalent.

\section{2 Test Setup and procedures}

Cells $57,15,51$ and 35 were tested individually and mounted as shown in Figures $01 \mathrm{~A}$ and $01 \mathrm{~B}$. Cells 23, 10 and 15 were tested in a rack similar in construction to the ones employed at the Fitzpatrick NPP/4/. This mounting arrangement is shown in Figure 25A. During all the tests, the voltage and current were monitored by the Chemical Department/5/. 
For each seismic test the intensity of the vibration was increased from a low level to the shaker limit or until a failure (electrical or mechanical) occurred. The highest level without failure was then plotted. The accelerometers were mounted at the base on a cell terminal.

Instrumented impact tests were performed on Item \#3 in both the torsional and bending modes. The vibration tests were then performed in three axes. The mounting details are shown in Figure $10 B$.

\subsection{Vibration Tests}

The shaker consists of random generators and hydraulic actuators which are capable of driving the shaker in three directions simultaneously. The shaker has the following limitation in each axis:

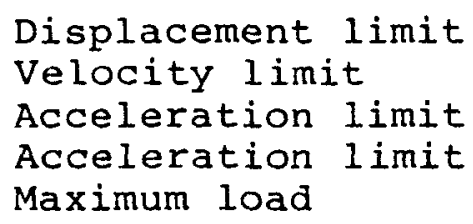

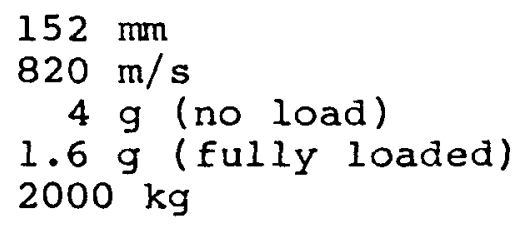

A simultaneous input was applied in three axes to ensure that all three response spectrums were enveloped, except for Item 2 where two horizontal axes were tested separately from the vertical axes.

\subsection{RESULTS}

The test results are given in Figures 01B through 29. In addition, a complete test history is supplied for each cell in Table I.

The minimum standard ZPA's are given in Table II. 


\section{CONCLUSIONS}

Of the seven batteries tested none experienced any electrical or structural damage as a result of the tests.

Approved :

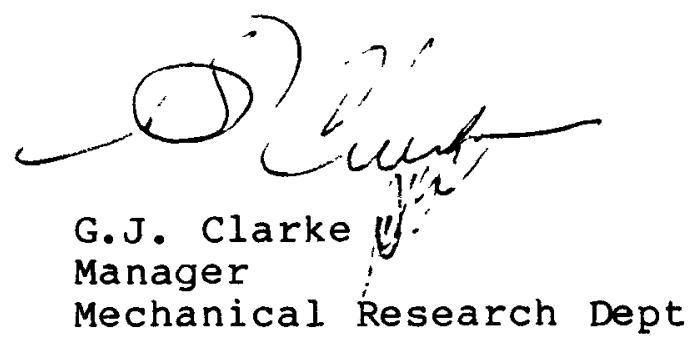

$G D P: D A B: s f$
Submitted:

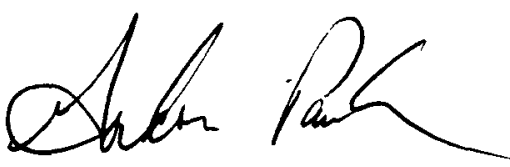

G. D. Paulseryaz Technologist Mechanical Testing and Development section

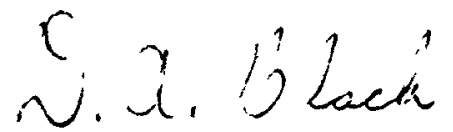

D. A. Black Eng ineer Mechanical Testing and Development section

\section{REFERENCES}

1. The Institute of Electrical and Electronic Engineers Inc. IEEE 344. Qualification of Class lE Equipment for Nuclear Power Generating Stations. New York. 1975.

2. The Institute of Electrical and Electronic Engineers Inc. IEEE 501. IEEE Recommended Practices for Seismic Qualification of Relays.

3. Harris, Cyril M., and Charles E. Crede. "Shock and Vibration Handbook". Second Edition. McGraw Hill Book Company. Toronto. 1976 .

4. D.A. Black and G.D. Paulsen. "Seismic Testing of Fitzpatrick Nuclear Generating station Simulated Battery Rack with Cells." Report No B84-37-P. July 19, 1984 .

5. W.J. Janis. "Seismic Testing of Calvert Cliffs Nuclear Power Station Batteries - Cell Inspection and Capacity Tests". Research Report C84-120-P. December, 1984. 
TABLE I

TEST HISTORY - CALVERT CLIEFS N.P.P. - EXIDE - MODEL FHC-19

\begin{tabular}{|c|c|c|c|c|c|c|}
\hline & el1 & Date & Time & Run & Span & Comments \\
\hline & 57 & July $23 / 84$ & $\begin{array}{l}2: 00 \\
2: 02 \\
2: 03 \\
2: 05 \\
2: 07 \\
2: 10\end{array}$ & $\begin{array}{l}1 \\
2 \\
3 \\
4 \\
5 \\
6\end{array}$ & $\begin{array}{l}3 \\
3 \\
4 \\
5 \\
6 \\
7\end{array}$ & $\begin{array}{l}\text { No load applied } \\
\text { Load on } \\
\text { Plotted }\end{array}$ \\
\hline & 15 & July $23 / 84$ & $\begin{array}{l}3: 10 \\
3: 11 \\
3: 12 \\
3: 13 \\
3: 22\end{array}$ & $\begin{array}{l}1 \\
2 \\
3 \\
4 \\
5\end{array}$ & $\begin{array}{l}4 \\
5 \\
6 \\
7 \\
7\end{array}$ & $\begin{array}{l}\text { Plotted } \\
\text { Clamps loosened }\end{array}$ \\
\hline & 51 & July $24 / 84$ & $\begin{array}{l}10: 08 \\
10: 09 \\
10: 10 \\
10: 11 \\
10: 12\end{array}$ & $\begin{array}{l}1 \\
2 \\
3 \\
4 \\
5\end{array}$ & $\begin{array}{l}4 \\
5 \\
5 \\
6 \\
7\end{array}$ & $\begin{array}{l}\text { No } Y \text { axis input } \\
\text { Retest } \\
\text { Plotted }\end{array}$ \\
\hline & 35 & July $24 / 84$ & $\begin{array}{l}11: 11 \\
11: 12 \\
11: 13 \\
11: 14\end{array}$ & $\begin{array}{l}1 \\
2 \\
3 \\
4\end{array}$ & $\begin{array}{l}4 \\
5 \\
6 \\
7\end{array}$ & Plotted \\
\hline 23. & 10,15 & July $25 / 84$ & $\begin{array}{l}2: 45 \\
2: 46 \\
2: 57 \\
2: 49\end{array}$ & $\begin{array}{l}1 \\
2 \\
3 \\
4\end{array}$ & $\begin{array}{l}4 \\
5 \\
6 \\
7\end{array}$ & Plotted \\
\hline
\end{tabular}


TABLE II

\section{TEST RESULTS AT SPAN 7}

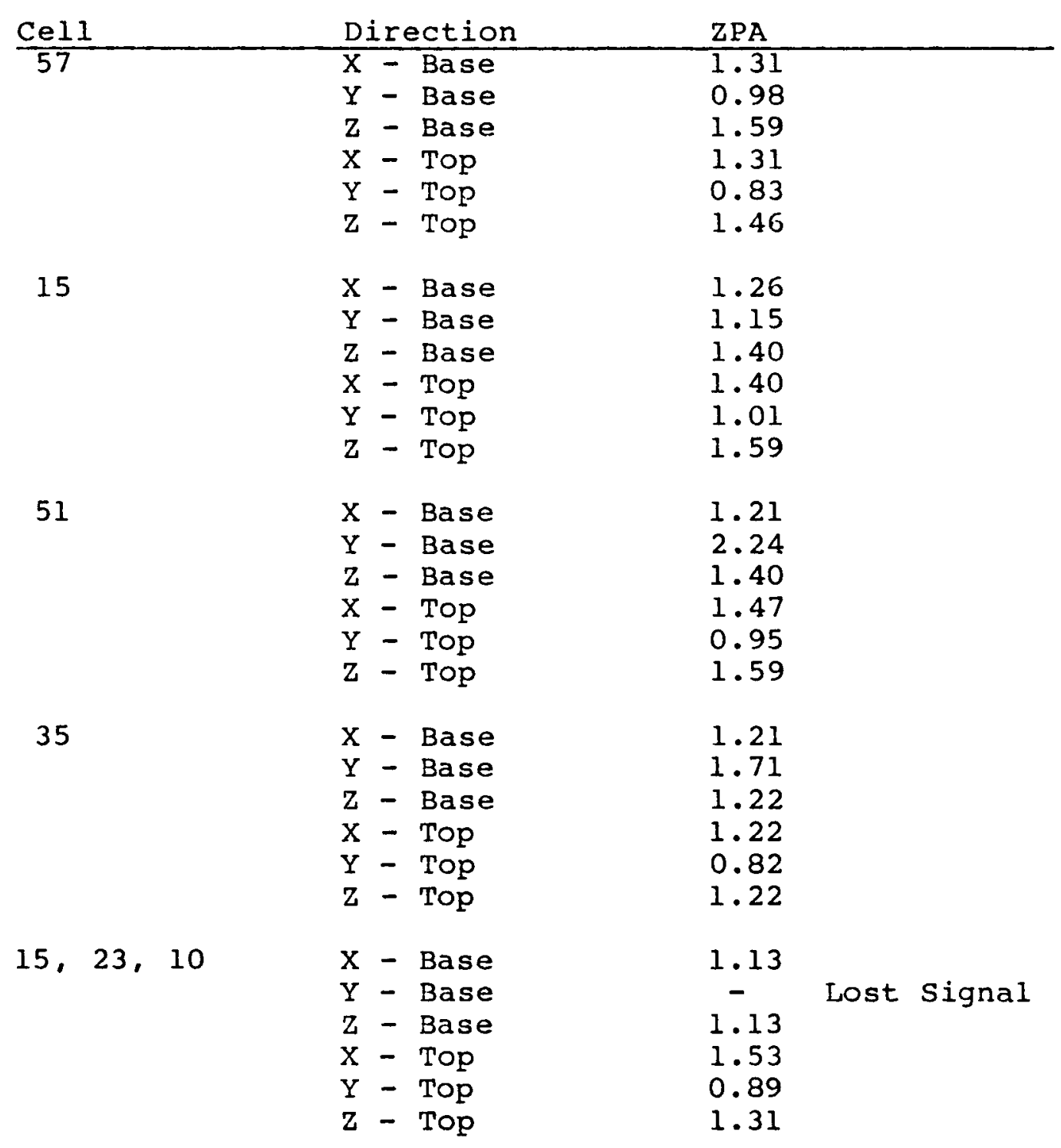




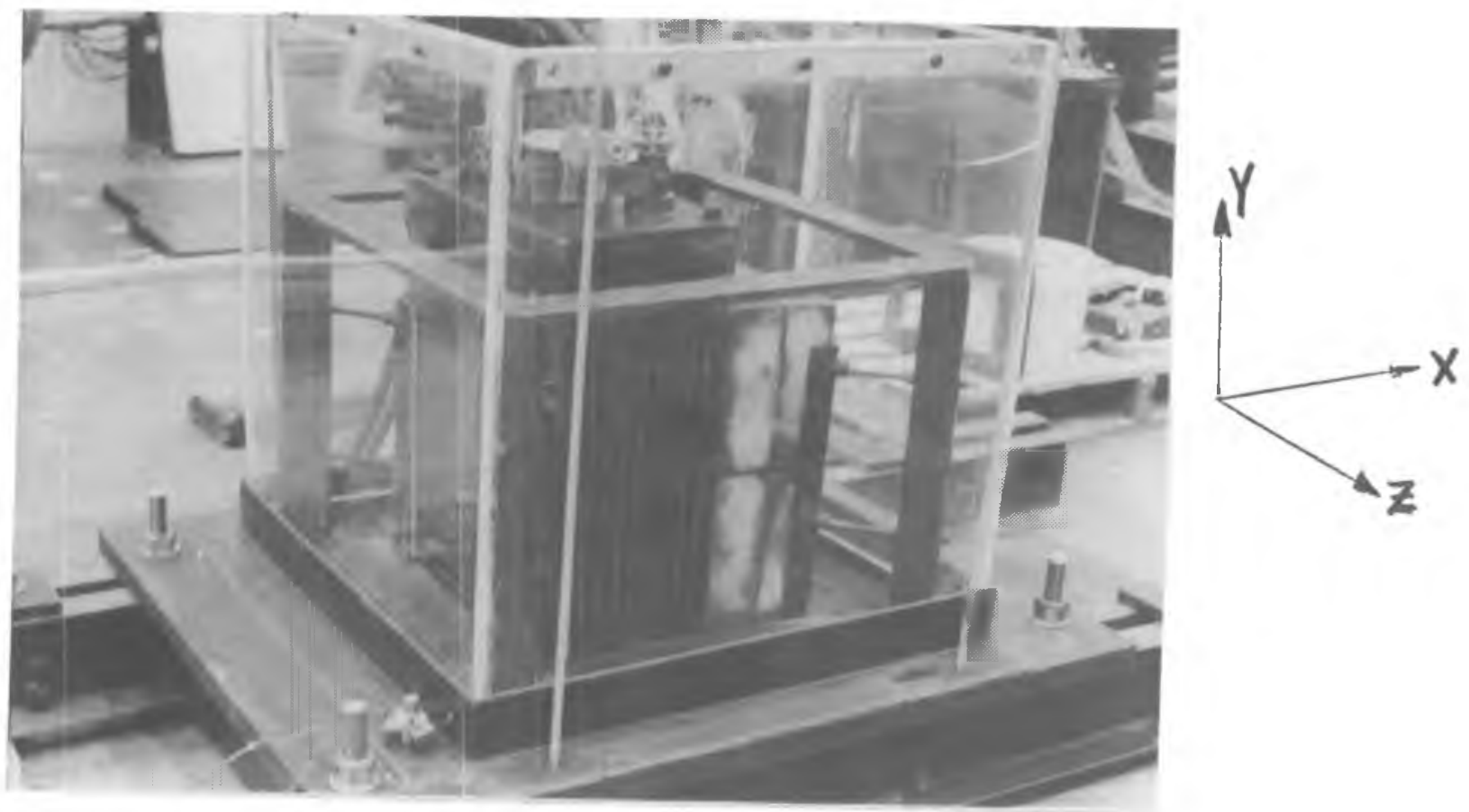

FIGURE 01A

THE CALVERT CLIFFS N,P,P, STATION CELL IS SHOWN MOUNTED ON THE TRI-AXIAL SHAKER TABLE, THE TEST JIG WAS MODIFIED WITH WOODEN BLOCKS TO FIT THE SMALLER EXIDE CELLS, THE ACCELEROMETER DIRECTIONS ARE AS INDICATED. 


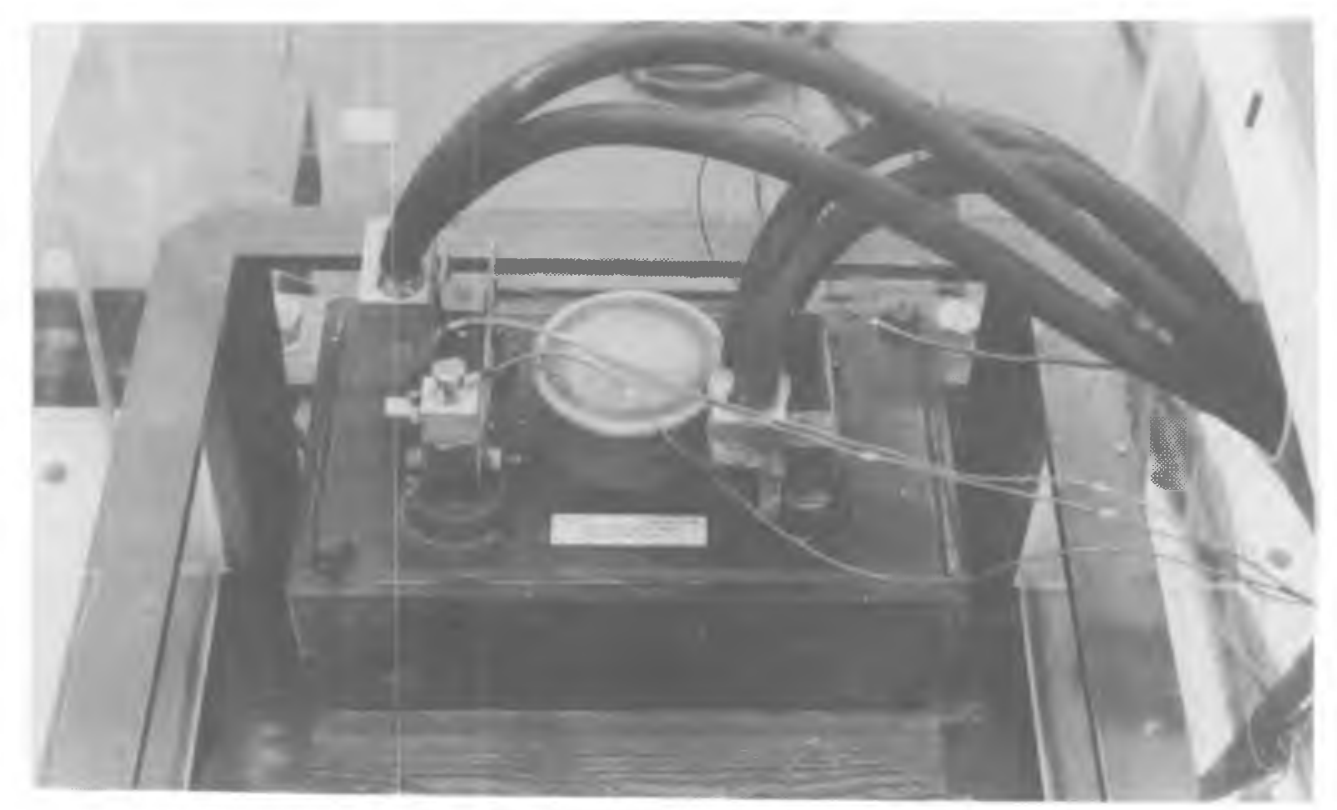

FIGURE OIB

THIS PHOTO SHOWS THE ACCELEROMETER PLACEMENT AND THE MONITORING DETAILS OF THE EXIDE MODEL FHC-19 CELLS, DURING THE TESTS THE CURRENT AND VOLTAGE OUTPUT WAS MONITORED BY CHEMICAL RESEARCH,

$$
D-9-
$$




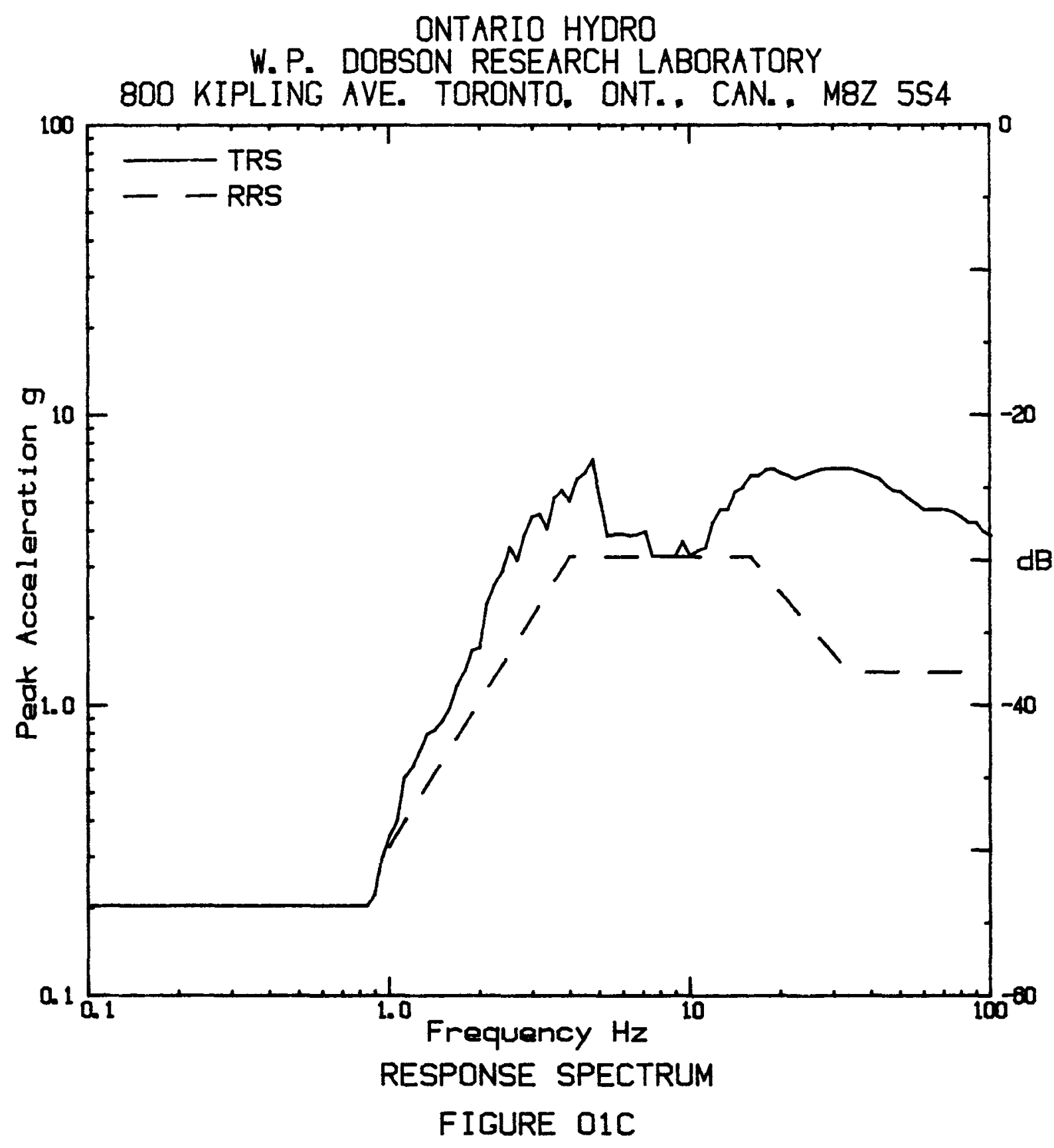

TEST ITEM

Station cell. Exide Modal FHC-19, Serial 57. Calvert Cliffs N.P.P.

PARTICULARS

July 23/84. Time 2 13. Tomp('C) 23. Humidity (X) 53, Press (kPa) 100. 2. Graph 5200

SPECIFICATIONS

Specs IEEE 501. Conditions operating 3 hour rate ispan 7

ANALYSIS

Type Maximax, Damping (Z) 5, B. $W_{0}=1 / 12$ Dctaves, Axis $X_{0}$

Shaker tri-axial, $Z P R=1$. 3. $1 \mathrm{~g}$

ACCELEROMETER

Wilcoxon Serial S771. Range dB49, Location base-mounting plate. Channel 1 


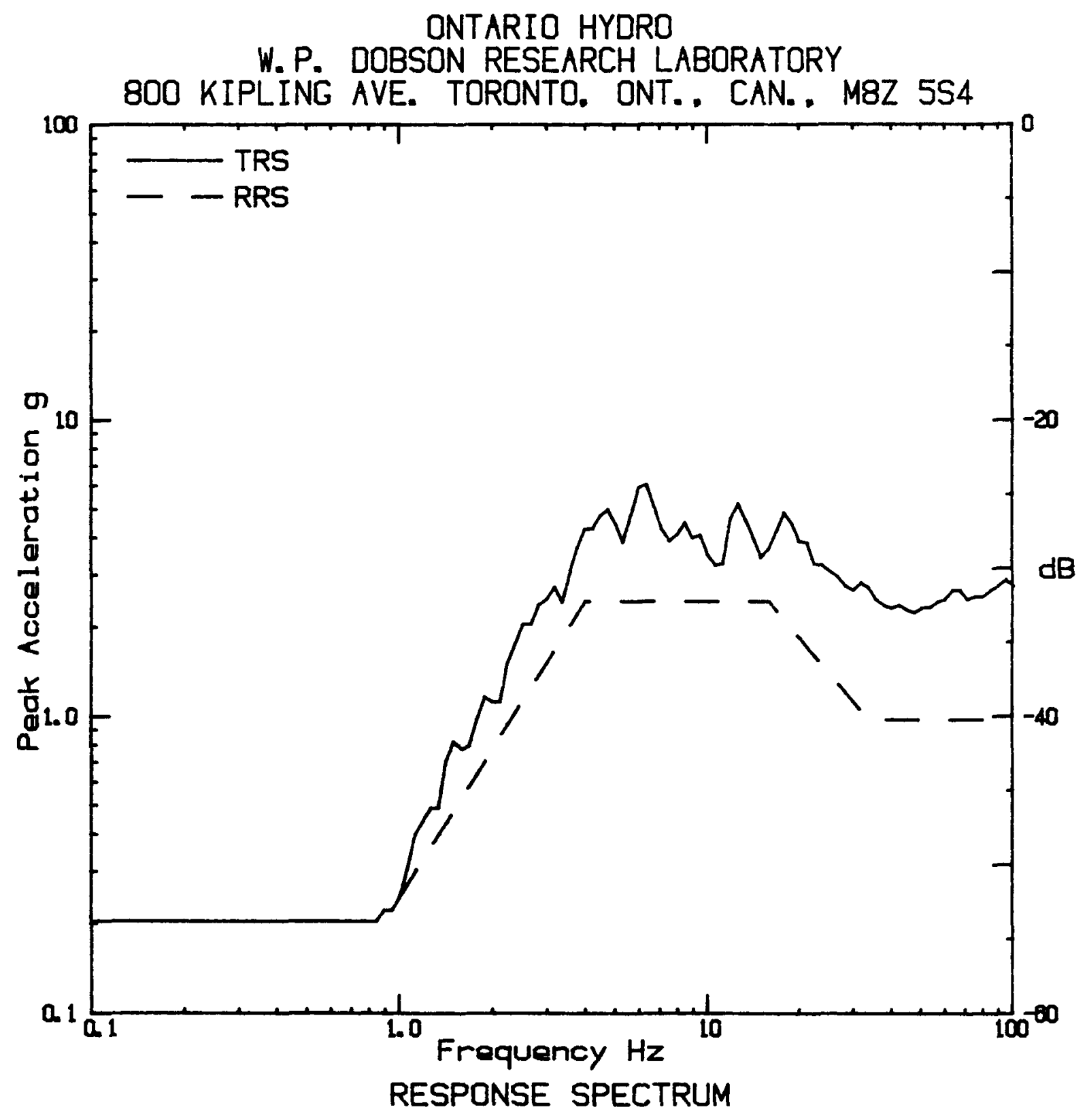

FIGURE 02

TEST ITEM

Station call, Exide, Madal FHC-19, Sorial 57. Calvert Cliffs N.P.P.

PARTICULARS

July 23/84. Time 2s 13. Temp('C) 23. Humidity (x) 53, Press (kPa) 100. 2. Graph 5201

SPECIFICATIONS

Specs IEEE 501. Conditions operating, 3 hour rate ispan 7

ANALYSIS

Type Haximax, Damping (x) 5, B. $W_{0}=1 / 12$ Octaves, Axis $Y_{0}$

Shaker tri-axial. ZPX =.98g

ACCELEROMETER

Wilcoxon, Sarial 5761. Range dB49, Location basa-mounting plate. Channel 2 
ONTARIO HYDRO

W. P. DOBSON RESEARCH LABORATORY

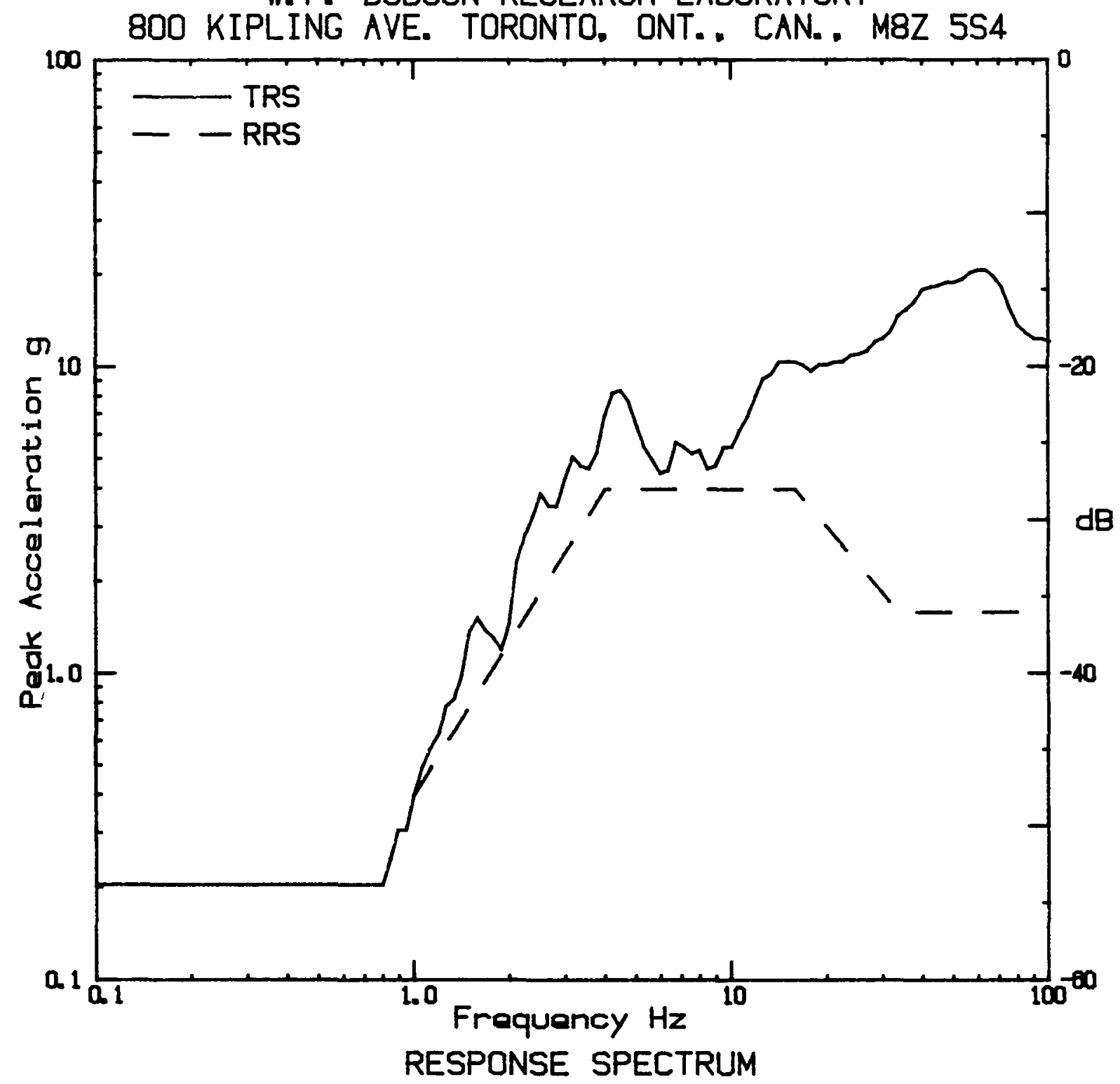

FIGURE 03

TEST ITEM

Station cell. Exide, Model FHC-19, Sorial 57, Calvart Cliffs N.P.P.

PARTICULARS

July 23/84, Time 2 13, Temp('C) 23. Humidity (z) 53, Pross (kPa) 100. 2. Graph 5202

SPECIFICATIONS

Spece IEEE 501. Conditions operating, 3 hour rate ispan 7

ANALYSIS

Type Maximax, Damping (x) 5, B. W. $=1 / 12$ Octaves, Axis Z.

Shaker tri-axial, ZPX=1.59g

ACCELEROMETER

Wilcoxon, Serial S297. Range dB49, Location baso-mounting plate. Channel 3 


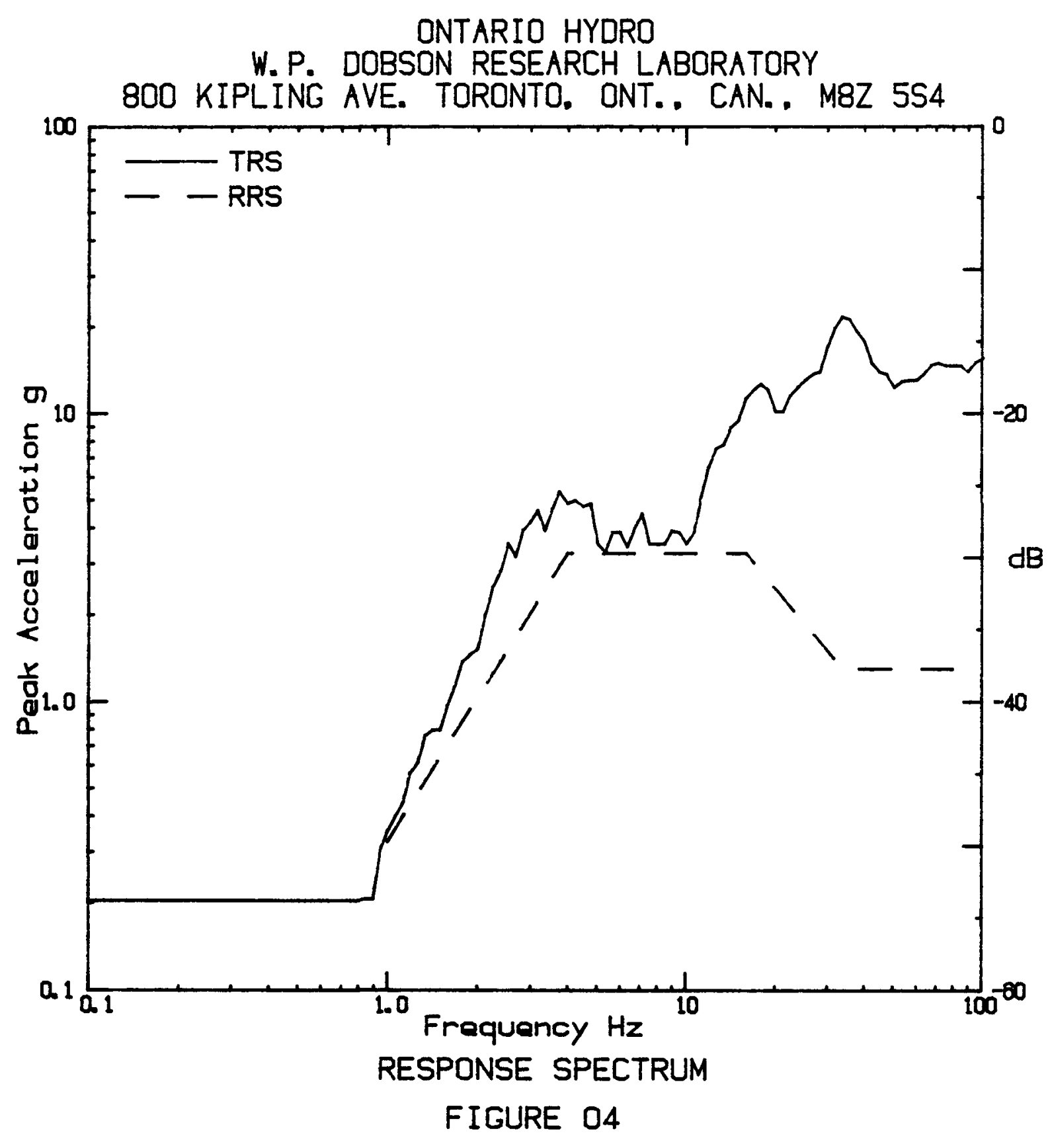

TEST ITEM

Station cell. Exide, Model FHC-19, Serial 57, Calvart Cliffs N.P.P.

PARTICULARS

July 23/84, Time 2313. Tomp('C) 23. Humidity(x) 53. Press (kPa) 100. 2. Graph 5203

SPECIFICATIONS

Spece IEEE 501. Conditions operating, 3 hour rate ispan 7

ANALYSIS

Type Maximax, Damping (X) 5 , B. $W_{0}=1 / 12$ Dctaves, Axis $X_{0}$

Shaker tri-axial. ZPK=1.31g

ACCELEROMETER

Wilcoxon, Sorial S757, Range dB49, Location top-cell terminal. 


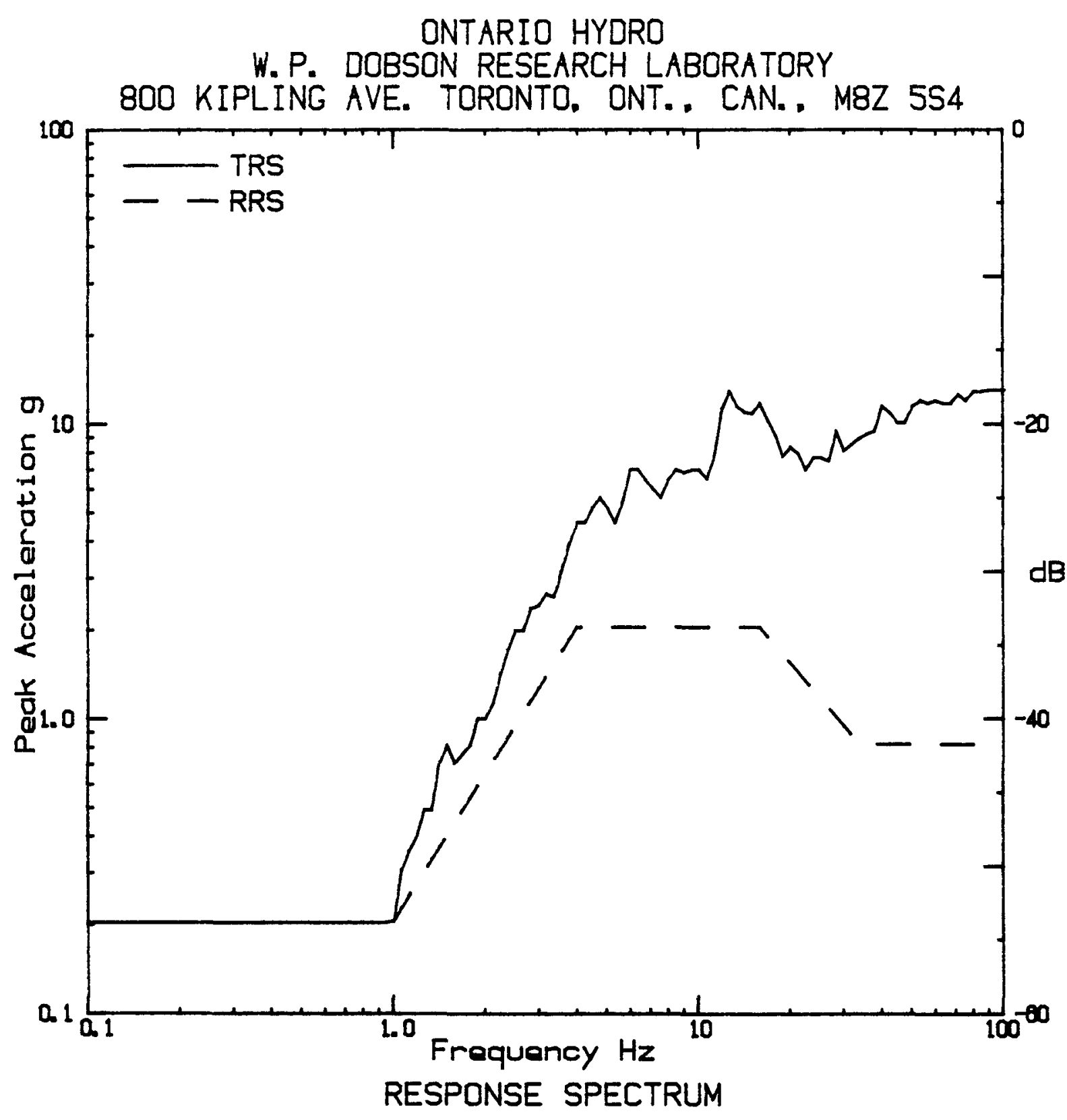

FIGURE 05

\section{TEST ITEM}

Station coll. Exide Modal FHC-19. Sorial 57, Calvart Cliffs N.P.P.

PARTICULARS

July 23/84, Time 2, 13. Tamp('C) 23, Humidity(X) 53, Prese (kPa) 100. 2. Graph 5204

SPECIFICATIONS

Spece IEEE 501. Conditions operating. 3 hour rate ispan 7

ANALYSIS

Type Maximax, Damping (z) 5, B. W. = $1 / 12$ Dctaves, Axis $Y_{\text {. }}$ Shaker tri-axial, $Z P X=.83 g$

ACCELEROMETER

Wilcoxon, Serial S754, Range dB49, Location top-cell terminal. Channel 5 
W. P. DOBSON RESEARCH LABORATORY

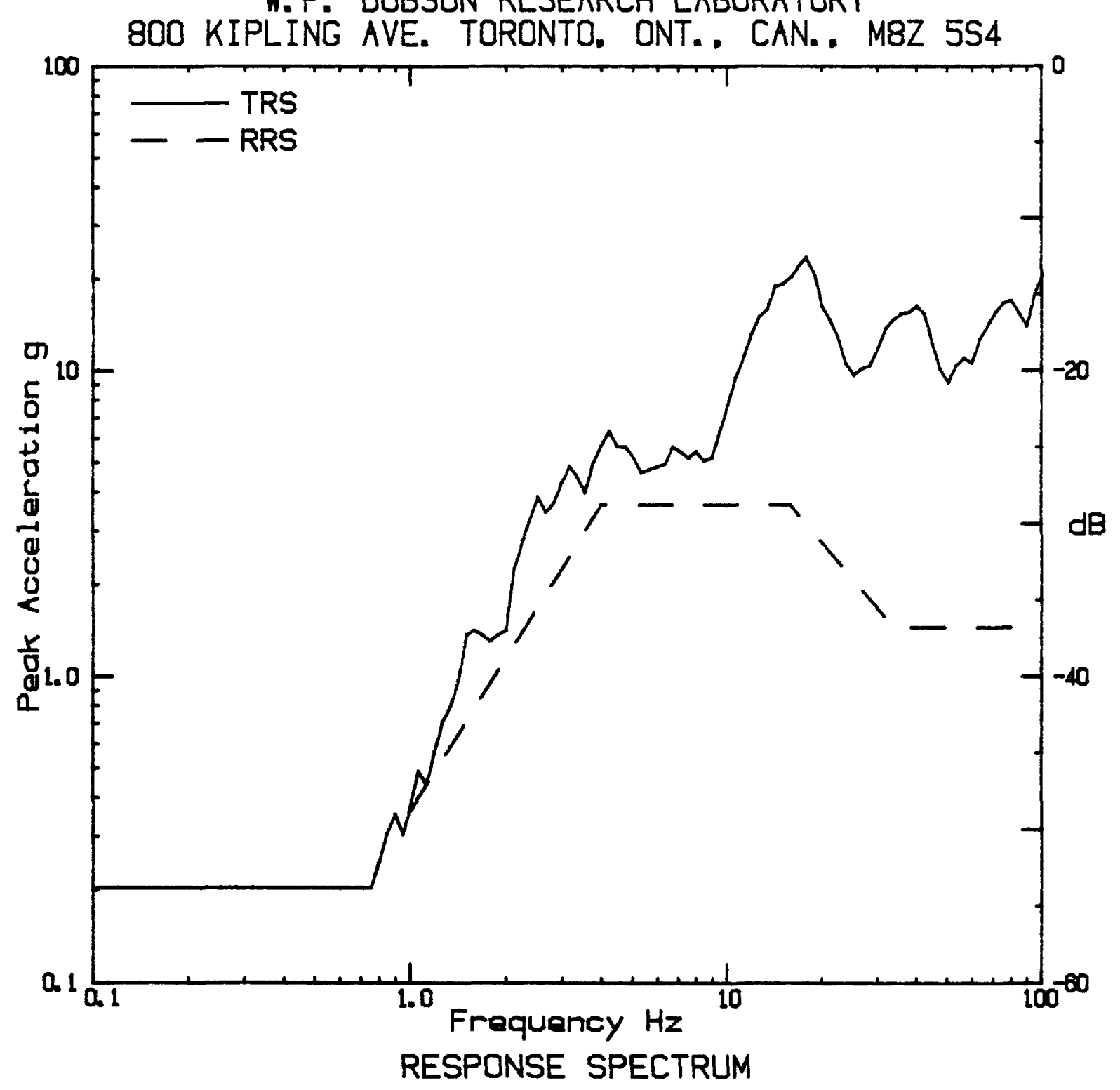

FIGURE 06

\section{TEST ITEM}

Station cell. Exide, Model FHC-19, Sarial 57. Calvart Cliffs N.P.P.

PARTICULARS

July 23/84. Time 2i 13. Tamp('C) 23. Humidity (x) 53. Press (kPa) 100. 2. Graph 5205

SPECIFICATIONS

Specs IEEE 501. Conditions operating. 3 hour rate ispan 7

ANALYSIS

Type Maximax, Damping (z) $5, B_{0} W_{0}=1 / 12$ Octaves, Axis $Z$.

Shaker tri-axial. $Z P R=1.46 \mathrm{~g}$

ACCELEROMETER Wilcoxon. Serial S901. Range dB49. Location top-cell terminal.
Channel $B$ 
W. P. DOBSON RESEARCH LABORATORY

800 KIPLING AVE. TORONTO, ONT., CAN., M8Z $5 S 4$

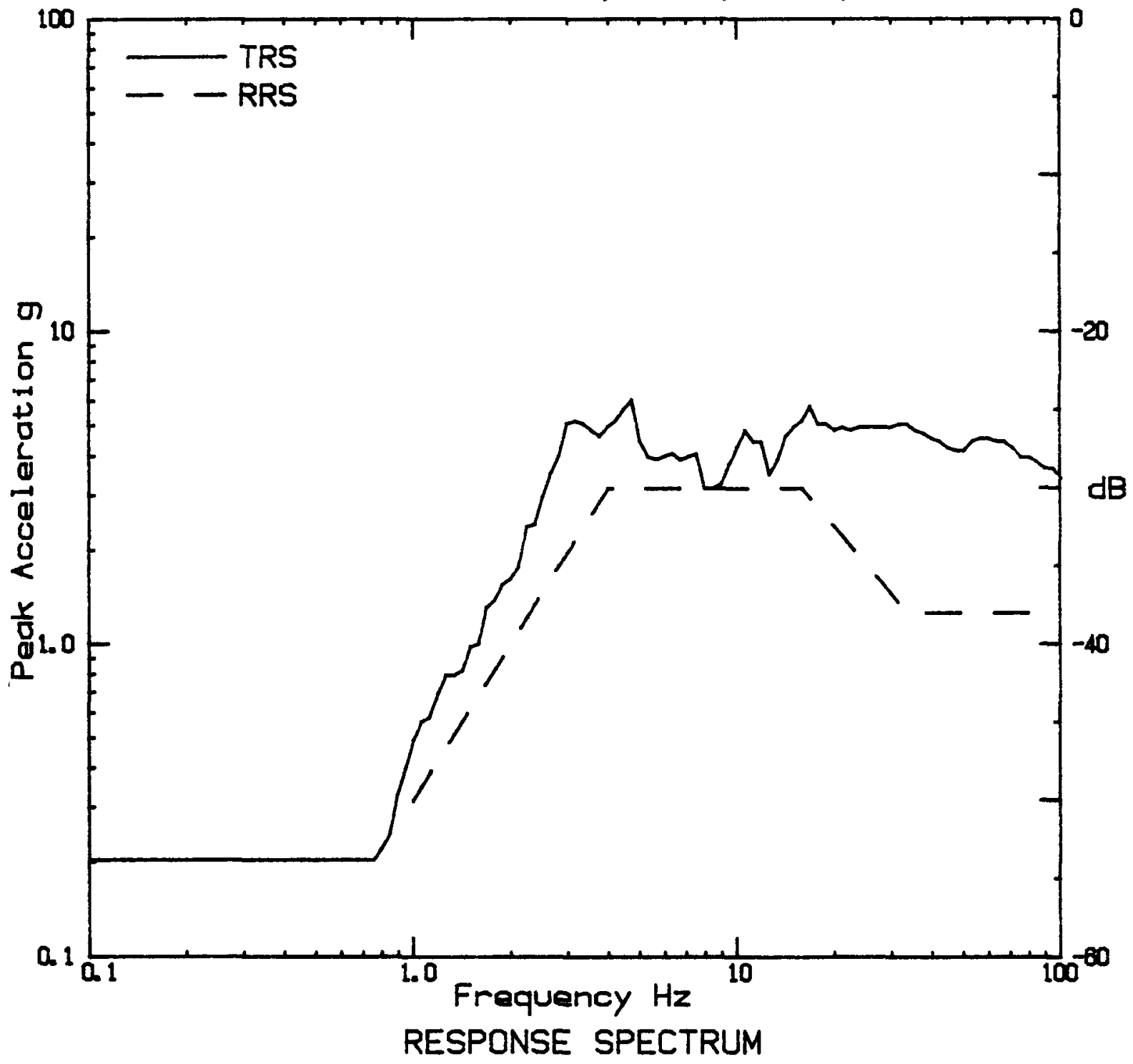

FIGURE 07

TEST ITEM

Station coll. Exide, Model FHC-19, Sorial 15. Calvart Cliffe N.P.P.

PART ICULARS

July 23/84, Time 23 45. Tomp('C) 23. Humidity(x) 53, Preos (kPa) 100. 2. Graph 5206

SPECIFICATIONS

Specs IEEE 501. Conditions operating, 3 hour rate, span 7

ANALYSIS

Type Maximax, Damping (z) 5. B. W. $=1 / 12$ Octavee, Axis $X_{0}$ Shaker tri-axial. $Z P X=1.26 \mathrm{~g}$

ACCELEROMETER

Wilcoxon, Sarial 5771. Range dB49, Location base-mounting plate. Channel 1 


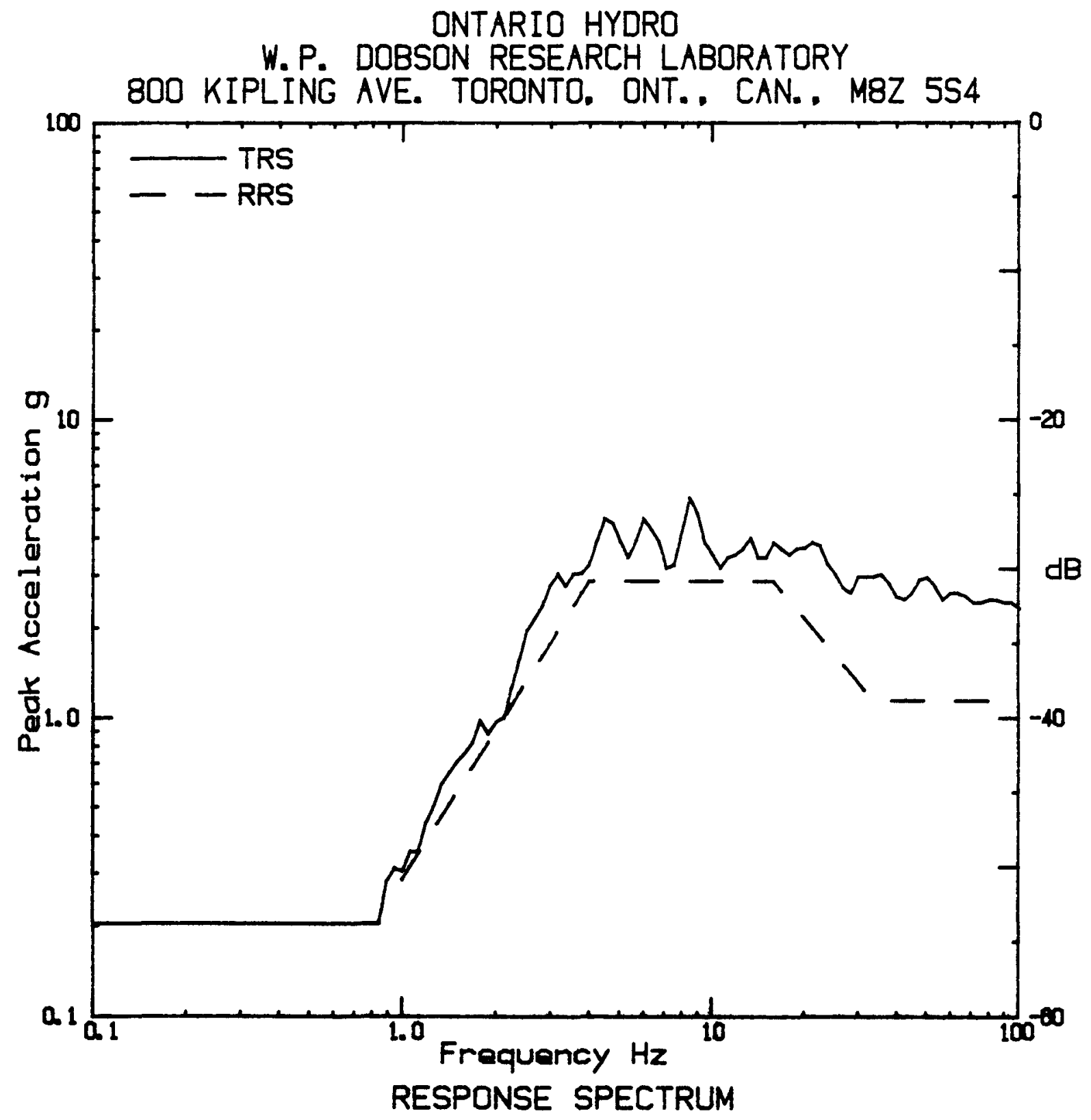

FIGURE 08

TEST ITEM

Station cell. Exide Model FHC-19, Sorial 15, Calvert Cliffe N.P.P.

PARTICULARS

July 23/94. Time 2 45. Tomp('C) 23. Humidity(x) 53, Praes (kPa) 100. 2. Graph 5207

SPECIFICATIONS

Spece IEEE 501. Conditions operating, 3 hour rate, epan 7

ANALYSIS

Type Maximax, Damping (X) 5 , B. W. = 1/12 Octaves, Axis $Y_{0}$

Shaker tri-axial. ZPX $=1.15 \mathrm{~g}$

ACCELEROMETER

Wilcoxon, Sarial S761. Range dB49, Location base-mounting plate.
Channel 2 


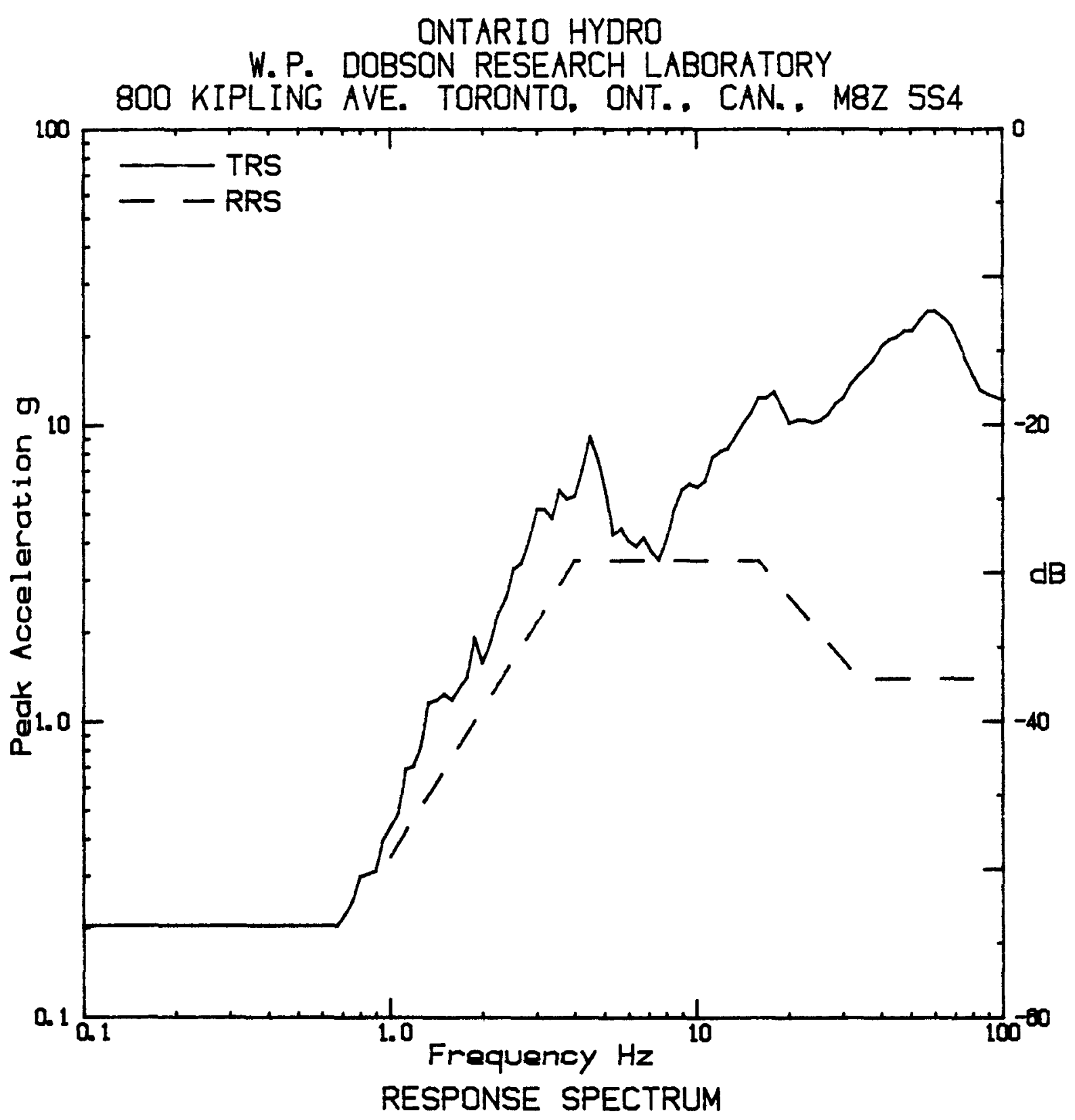

FIGURE 09

TEST ITEM

Station call, Exide, Modal FHC-19, Sarial 15, Calvart Cliffo N.P.P.

PARTICULARS

July 23/84, Time 2 45. Tomp ('C) 23, Humidity (x) 53, Pross (kPa) 100.2. Graph 5208

SPECIFICATIONS

Spece IEEE 501. Conditions operating, 3 hour rate, span 7

ANALYSIS

Type Maximax. Damping (x) 5, B. W. = 1/12 Octaves, Axis Z.

Shaker tri-axial. $Z P X=1.4 \mathrm{~g}$

ACCELEROMETER

Wilcoxon, Sarial 5297. Range dB49, Location base-mounting plate. 


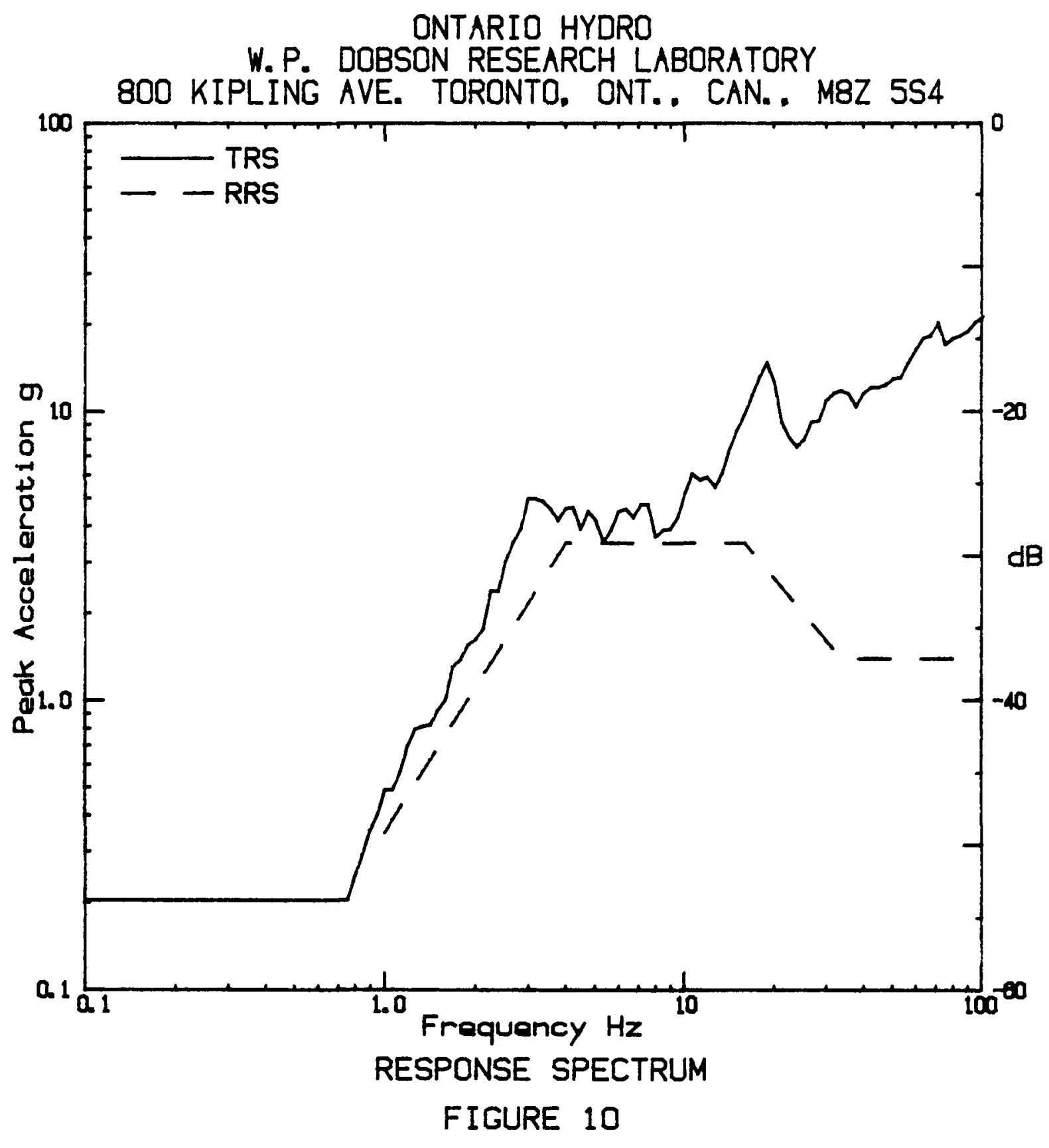

TEST ITEM

Station cell. Exide, Model FHC-19, Serial 15, Calvert Cliffe N.P.P.

PARTICULARS

July 23/84, Time 2, 45, Tomp ('C) 23, Humidity (x) 53, Prees (kPa) 100. 2. Graph 5209

SPECIFICATIONS

Spece IEEE 501. Conditione operating, 3 hour rates epan 7

ANALYSIS

Type Maximax, Damping (x) 5 , B. $W_{0}=1 / 12$ Octovee, Axis $X_{0}$

Shaker tri-axial. $Z P X=1.4 \mathrm{~g}$

ACCELEROMETER

Wilcoxon Serial 5901. Range dB49. Location top-cell terminal. Channol 4 


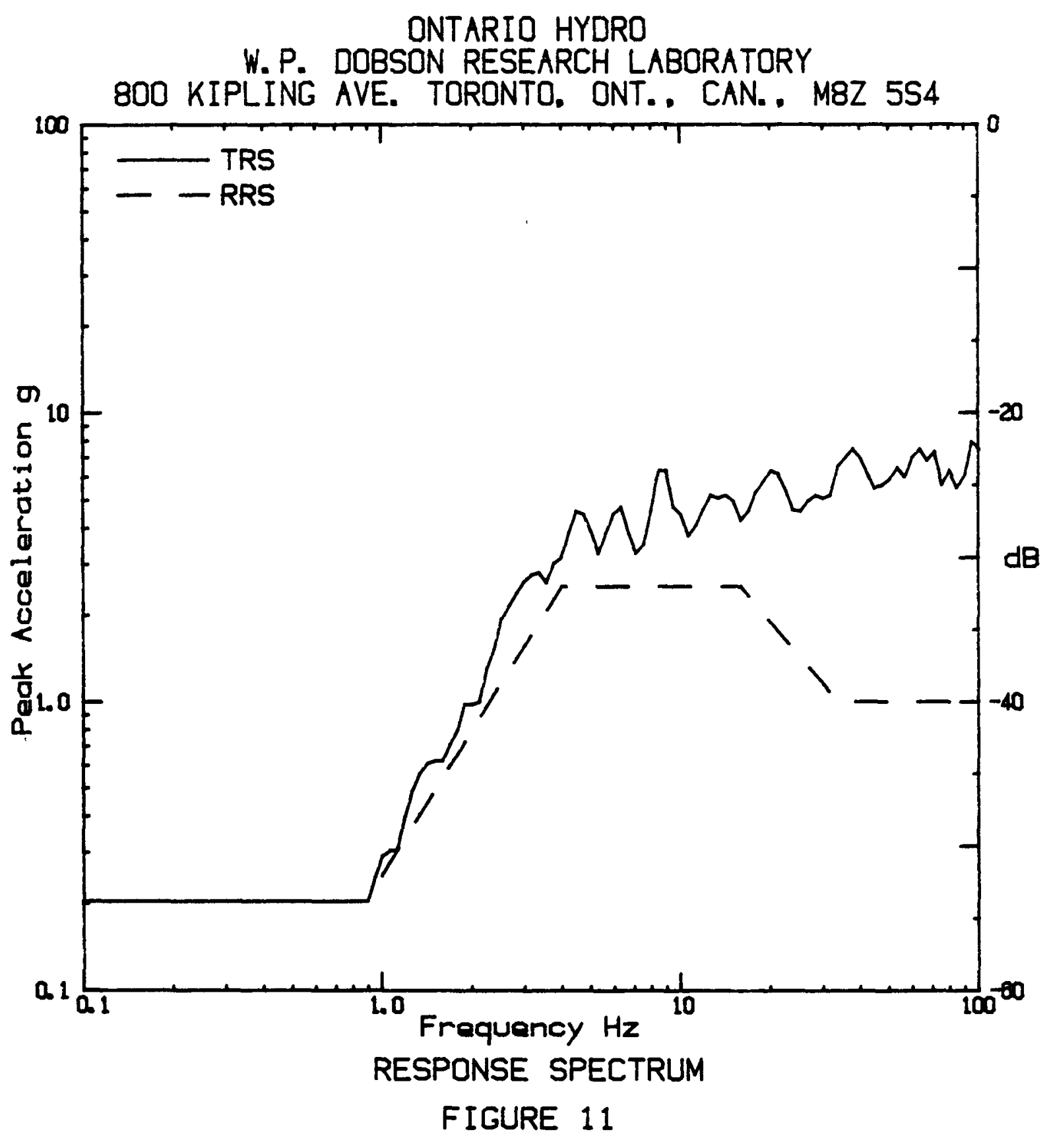

TEST ITEM

Station cell. Exide Modal FHC-19, Sarial 15, Calvart Cliffe N.P.P.

PARTICULARS

July 23/84, Time 23 45. Tamp('C) 23. Humidity(x) 53. Prees (kPa) 100. 2. Graph 5210

SPECIFICATIONS

Spece IEEE 501. Conditions operating, 3 hour rate, opan 7

ANALYSIS

Type Maximax, Damping (X) 5, B. W. = 1/12 Octaves, Axis Y. Shaker tri-axial. ZPX =1.01g

ACCELEROMETER

Wilcoxon, Sorial S754, Range dB49, Location top-cell terminal. Channel 5 


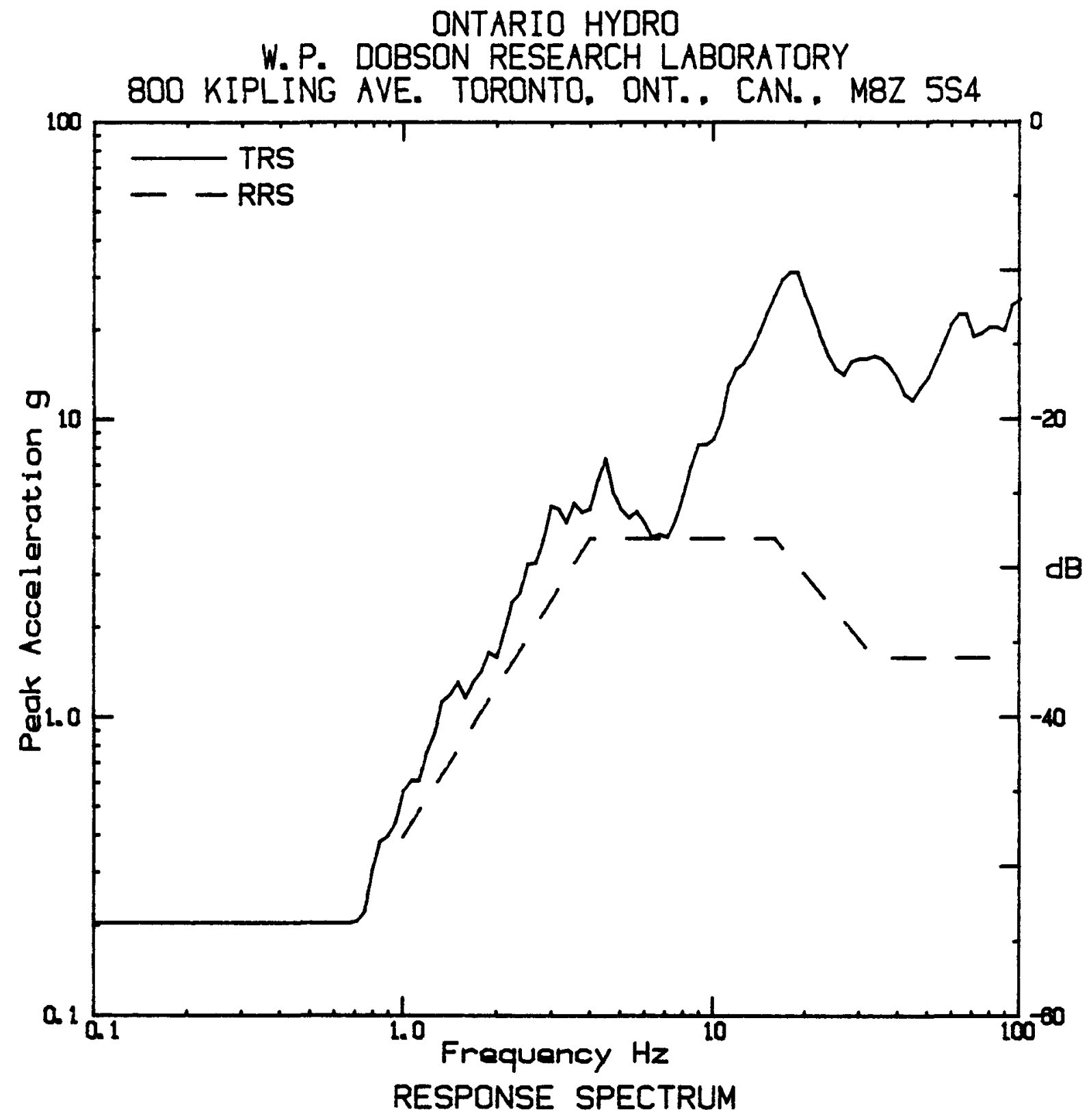

FIGURE 12

TEST ITEM

Station cell. Exide. Model FHC-19. Serial 15, Calvert Cliffo N.P.P.

PART ICULARS

July 23/84, Time 28 45. Temp('C) 23. Humidity (X) 53, Prose (kPa) 100. 2. Groph 5211

SPECIFICATIONS

Spece IEEE 501. Conditions operating, 3 hour rate, span 7

ANALYSIS

Type Maximax, Damping (Z) 5, B. $W_{0}=1 / 12$ Octavee, Axis $Z$. Shaker tri-axial. $Z P X=1.59 g$

ACCELEROMETER

Wilcoxon, Serial 5757. Range dB49, Location top-cell terminal. Channel 6 


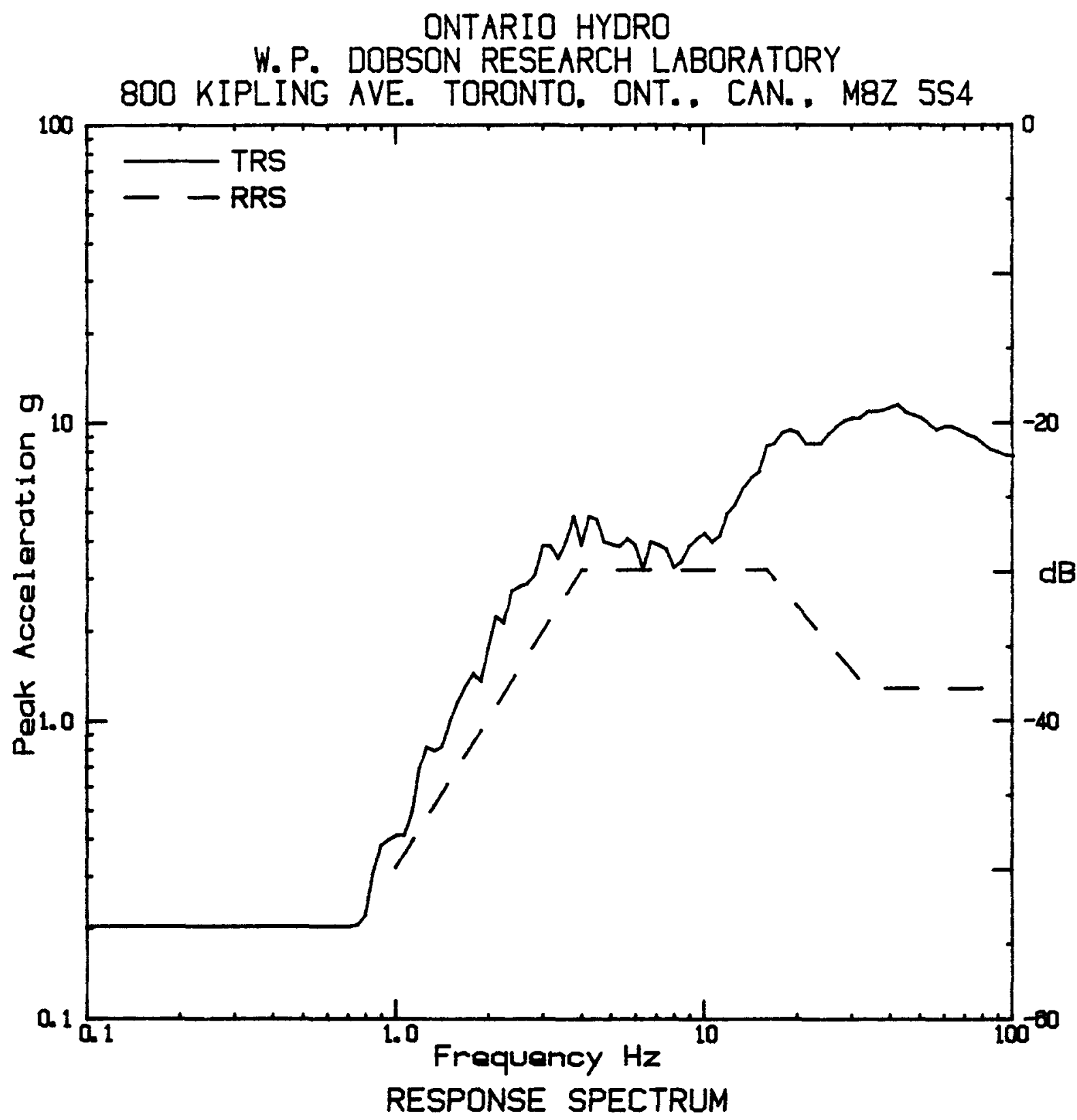

FIGURE 13

TEST ITEM

Station call, Exide, Madal FHC-19, Sorial 51. Calvart Cliffs N.P.P.

PARTICULARS

July 23/84, Tima 10. 12. Temp('C) 23. Humidity(x) 53.

Pross (kPa) 100. 2. Groph 5212

SPECIFICATIONS

Spece IEEE 501. Conditione operating, 3 how rate, span 7

ANALYSIS

Type Maximax, Damping (x) 5, B. W. = $1 / 12$ Dctavee, Axis $X_{*}$ Shaker tri-axial. $Z P X=1.29 \mathrm{~g}$

ACCELEROMETER

Wilcoxon Serial S771. Range dB49, Location base-mounting plate. Channel 1 


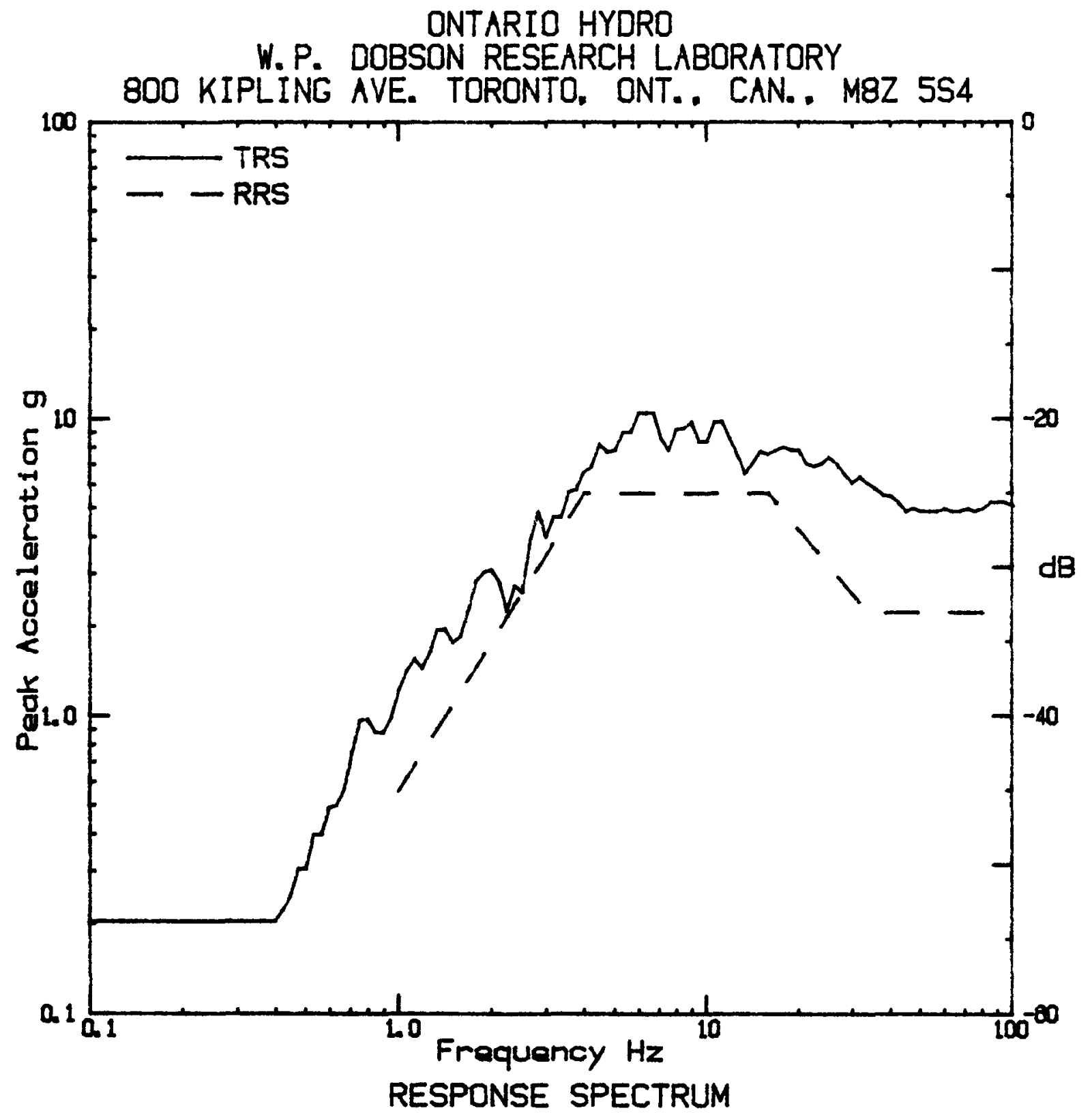

FIGURE 14

\section{TEST ITEM}

Station cell. Exide, Model FHC-19, Serial 51. Calvert Cliffe N.P.P.

PARTICULARS

July 23/94, Tima 10, 12. Tamp('C) 23, Humidity (x) 59,

Prase (kPa) 100. 2. Groph 5215

SPECIF ICATIONS

Spece IEEE 501. Conditions operating : 3 hour rate span 7

ANALYSIS

Type Maximax, Damping (x) 5, B. $W_{0}=1 / 12$ Octaves, Axis $Y_{\text {. }}$ Shaker tri-axial. ZPX=2. 249

ACCELEROMETER

Wilcoxon, Serial 5761. Ranga $\mathrm{OB} 49$, Location bose-mounting plate

Channel 2 
W. P. DOBSON RESEARCH LABORATORY

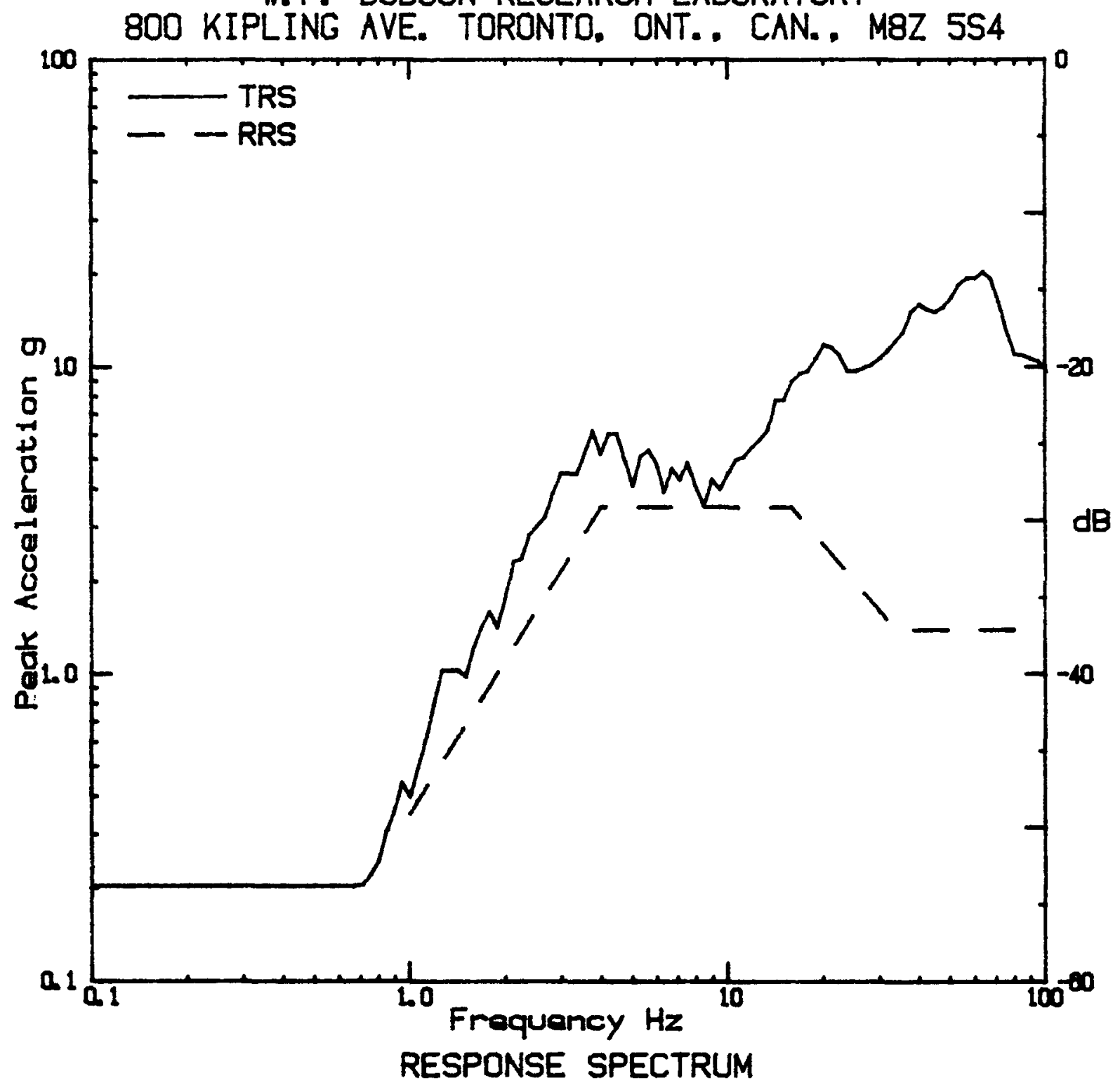

FIGURE 15

\section{TEST ITEM}

Station cell. Exida Modal FHC-19, Serial 51. Calvert Cliffe N.P.P.

PARTICULARS

July 23/94. Time 10,12. Tomp('O) 23. Humidity (X) 53.

Preee (kPa) 100 2. Graph 5214

SPECIFICATIONS

Spece IEEE 501. Conditions operating i 3 hour rate epan 7

ANALYSIS

Type Naximax, Danping (x) 5, B. W. = $1 / 12$ Dctaves, Axis Z.

Shaker tri-axial. ZPK $-1.4 \mathrm{~g}$

ACCELEROMETER

Vilcoxar, Sorial S297. Range dB49, Location baso-mounting plata Chamal 3 


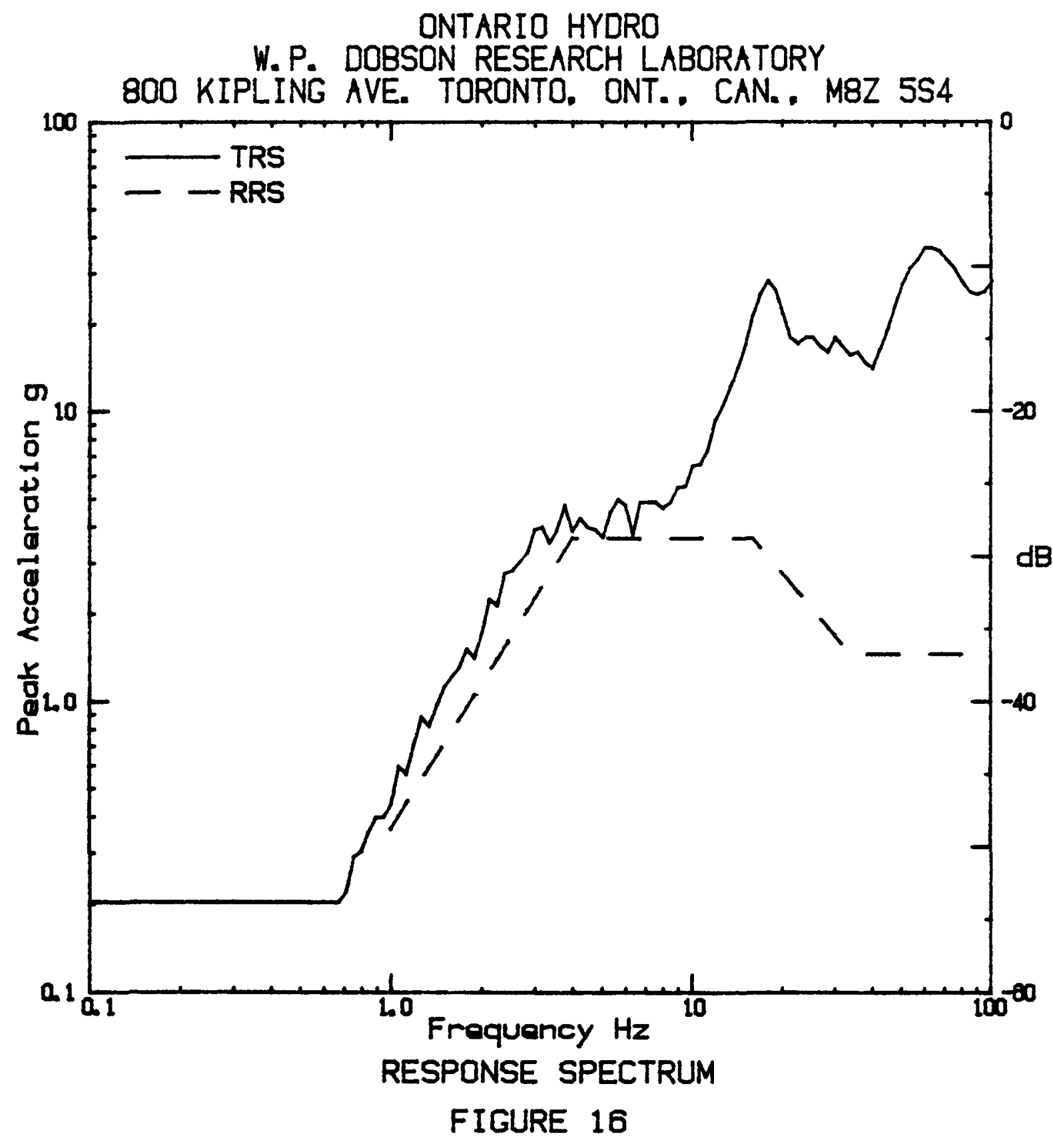

TEST ITEM

Station call. Exide Modol FHC-19, Sorial 51. Calvert Cliffe N.P.P.

PARTICULARS

July 23/84, Timo 10.12. Tomp('C) 23. Humidity(X) 59,

Proes (tePa) 100.2 . Graph 5215

SPECIFICATIONS

Specs IEEE 501. Conditions operating i 3 hour rate, epan 7

ANALYSIS

Type Maximax, Damping (D) 5, B. $W_{0}=1 / 12$ Octaves, Axis $X_{*}$

Shaker tri-axial. $Z P X=1.47 \mathrm{~g}$

ACCELEROMETER

Wilcoxon, Sorial S901. Range dB49, Location top-cell terminal, Channel 4 


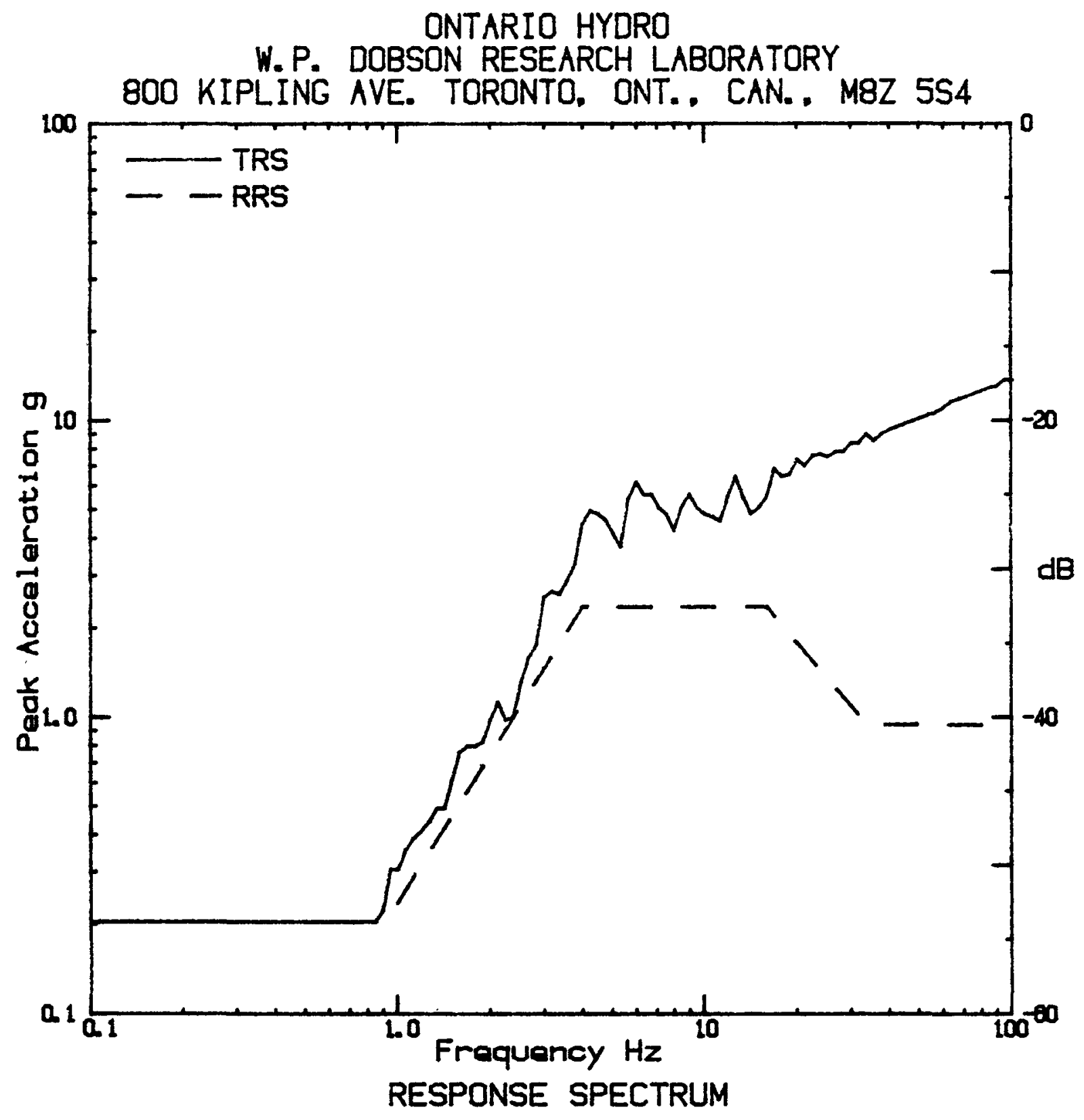

FIGURE 17

TEST ITEM

Station call. Exide Modal FHC-19, Serial 51. Calvart Cliffo N.P.P.

PARTICULARS

July 23/84, Time 10a 12. Tenp('C) 23. Humidity (X) 53,

Proes (kPa) 100 2. Graph 5216

SPECIFICATIONS

Spece IEEE 501. Conditions operating a 3 hour rate span 7

ANALYSIS

Type Maximax, Damping (x)5, B. W. = 1/12 Octaves, Axis $Y_{\text {. }}$

Shaker tri-axial, ZPX =.95g

ACCELEROMETER

Whannel 5 Serial 5754, Range d849, Location top-cell tarminal. 


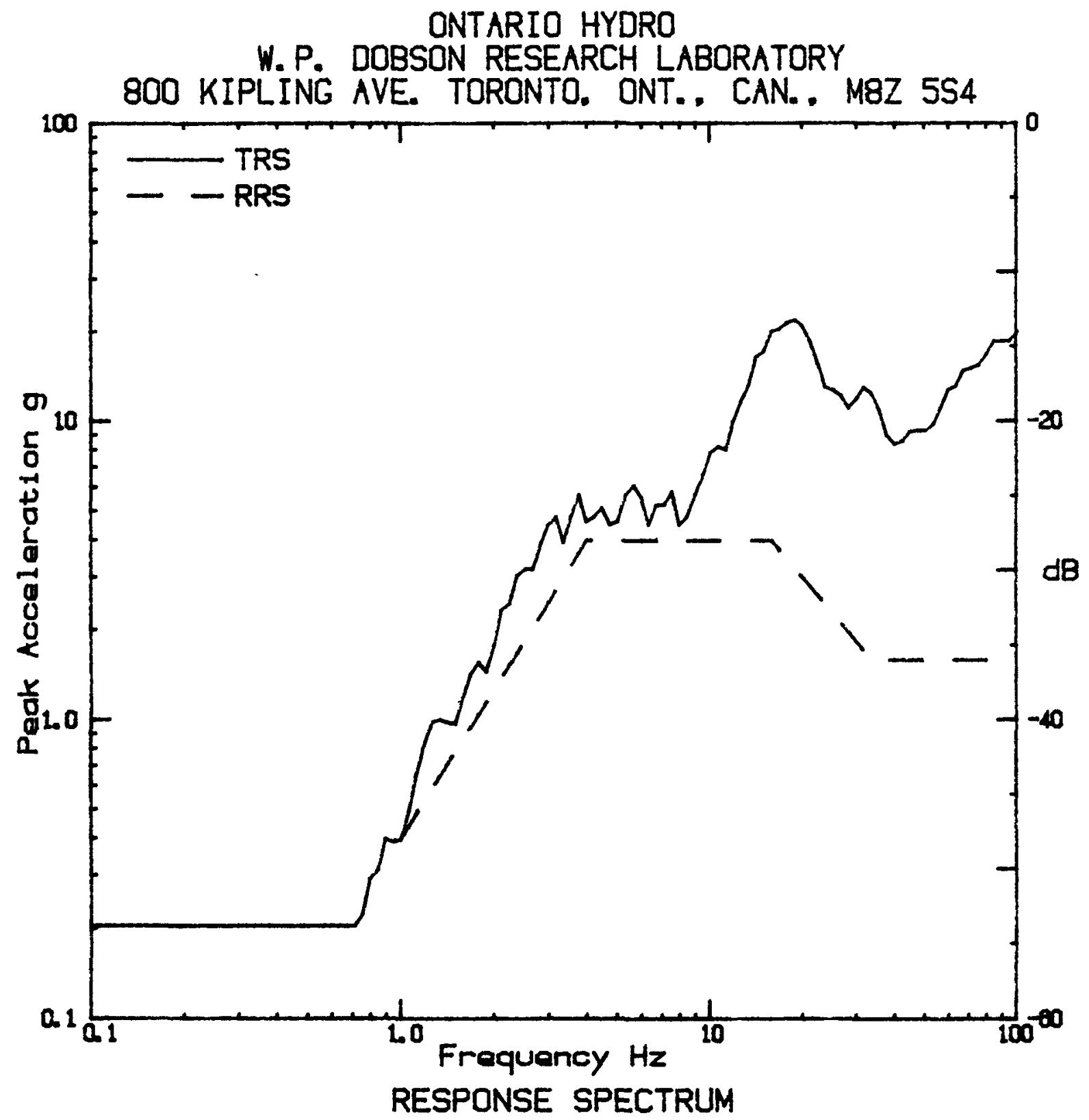

FIGURE 18

TEST ITEM

Station coll. Exide Model FHC-19, Serial 51. Calvert Cliffs N.P.P.

PARTICULARS

July 23/84, Time 10 12 Tap('C) 23, Humidity(D) 53,

Proes (KPa) 100 2. Eraph 5217

SPECIFICATIONS

Spece IEEE 501. Conditions oparating, I hour rate span 7

ANALYSIS

Typo Maximax, Damping (X) 5 , B. $W_{*}=1 / 12$ Dctaves, Axis Z.

Shaker tri-axial, ZPX=1.59g

ACCELEROMETER

Wilcoxon Sorial 5757, Range dB49, Location top-call torminal. Chamel 6 


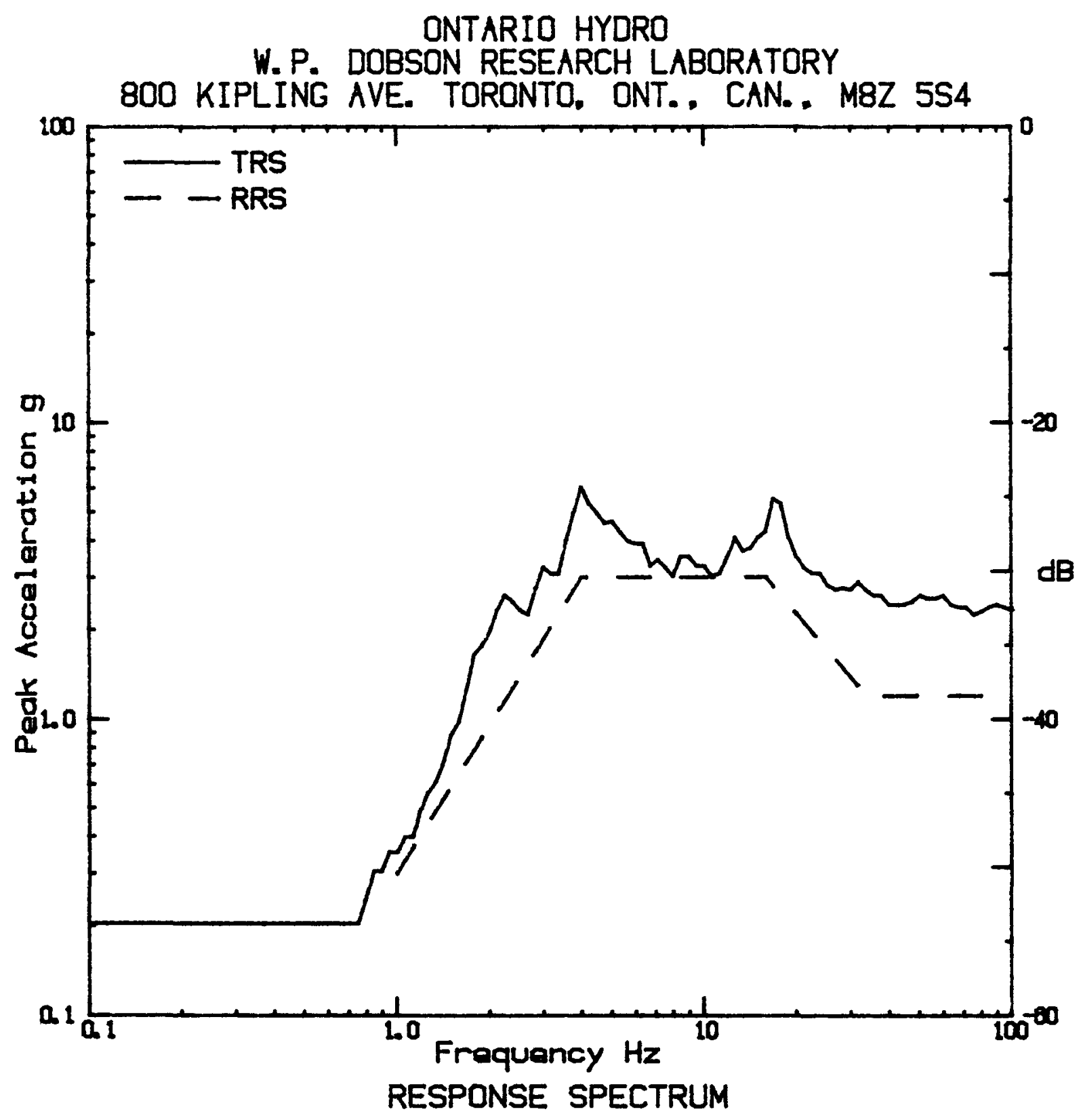

FIGURE 19

TEST ITEM

Station call. Exide, Model FHC-19. Sarial 35, Calvart Cliffo NP.P.

PARTICULARS

July 23/84, Tima 11:14, Tong('C) 23, Humidity (D) 53.

Proes (kPa) 100 2. Graph 5218

SPECIFICATIONS

Spece IEEE 501. Conditions operating, 3 hour rate span 7

ANALYSIS

Type Maximax, Daming $\cos 5$, B. $W_{0}=1 / 12$ Dctaves, Axis $X_{0}$ Shaker tri-axial. ZPX-1.21g

ACCELEROMETER

Wilcoxon Serial S771. Range d849, Location baso-mounting plate Chammal 1 


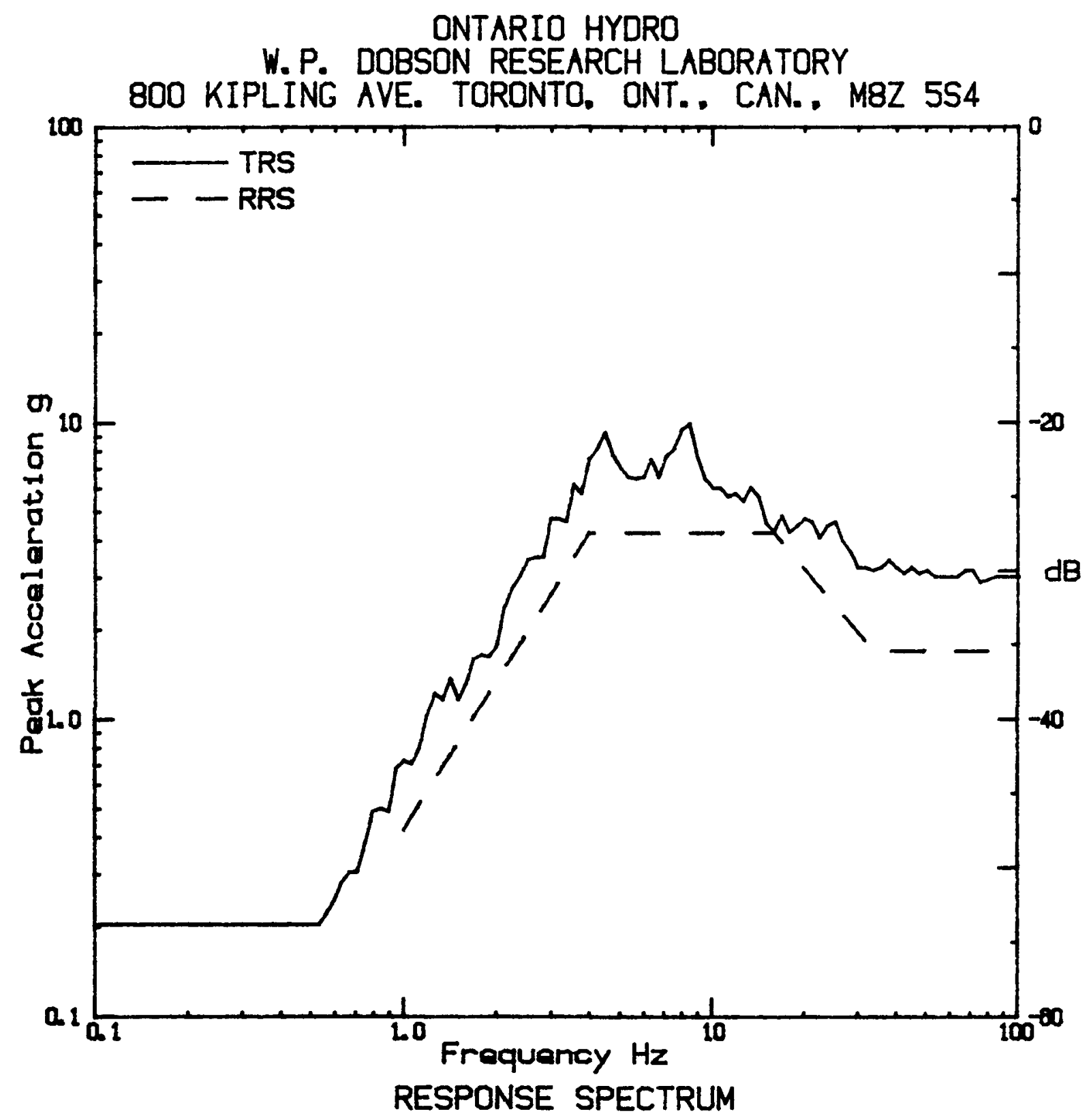

FIGURE 20

TEST ITEM

Station cell. Exida Model FHC-19, Serial 35, Calvert Cliffs M.P.P.

PARTICULARS

July 23/84, Timo 11: 14, Tamp('C) 23, Humidity (C) 53,

Preos (KPa) 1002 . Groph 5219

SPECIFICATIONS

Spece IEFE 501. Conditione operating, 3 hour rate span 7

ANALYSIS

Type Maximax, Daming $\cos 5$, B. $W_{0}=1 / 12$ Dctavos, Axis Y. Shaker tri-axial. ZPX-1.7ig

ACCELEROMETER

Chammel 2 Sorial 5781. Range dB49, Location booe-mounting plate, 
ONTARIO HYDRO

W. P. DOBSON RESEARCH LABORATORY

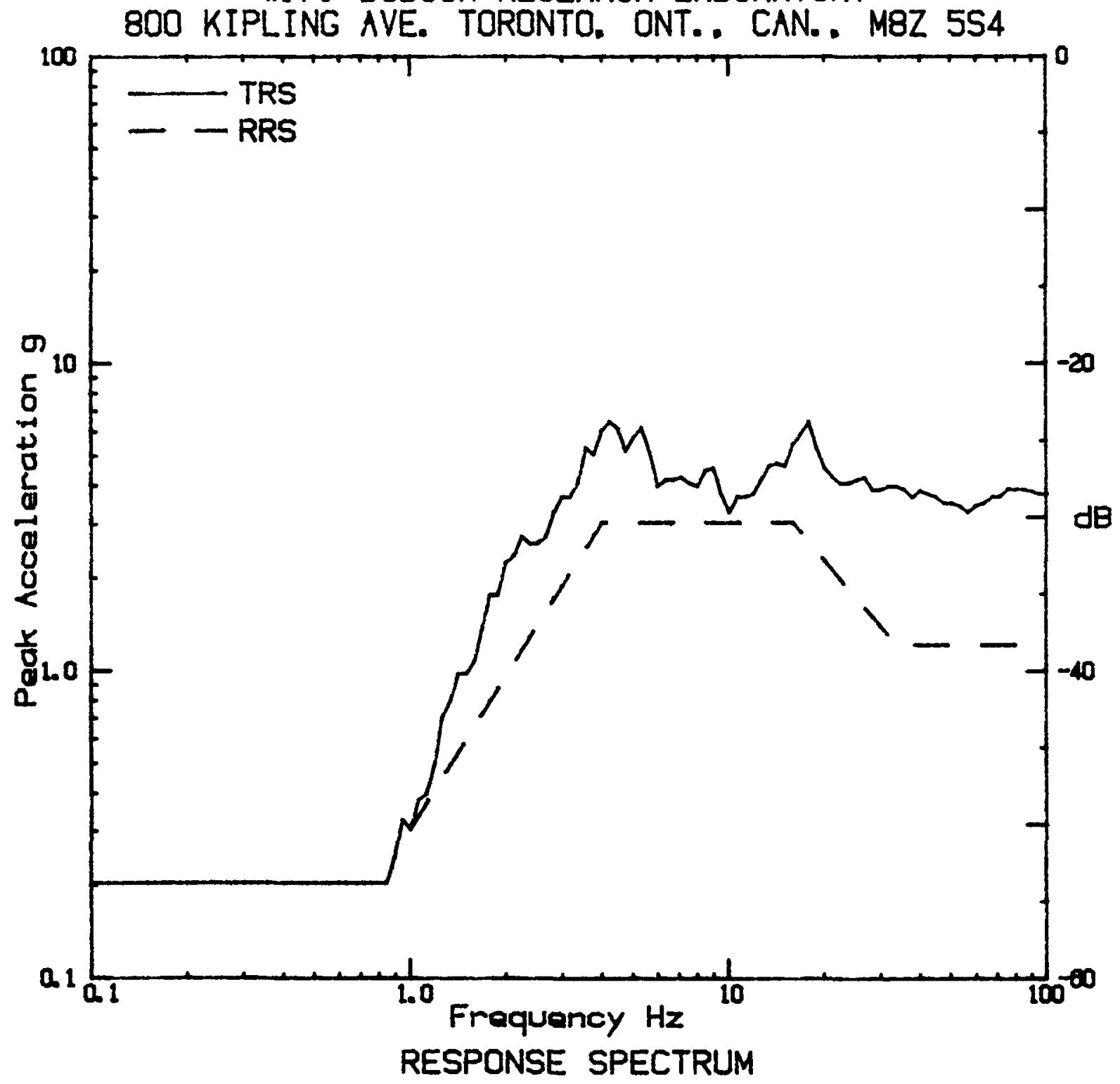

FIGURE 21

TEST ITEM

otation cell. Exide, Modal FHC-19, Sorial 35, Calvant Cliffe N.P.P.

PARTICULARS

July 23/84, Timo 11:14. Tamp ('C) 23. Humidity (X) 53.

Proes (KPa) 100. 2. Graph 5220

SPECIFICATIONS

Spece IEEE 501. Conditione operating 3 hour rate epan 7

ANALYSIS

Type Maximax, Damping (x)5, B.W. - 1/12 Dctoves, Axis Z. Shaker tri-axial, ZPX-1. 22g

ACCELEROMETER

Wilcoxon, Serial S297. Range dB49, Location base-mounting plate. 


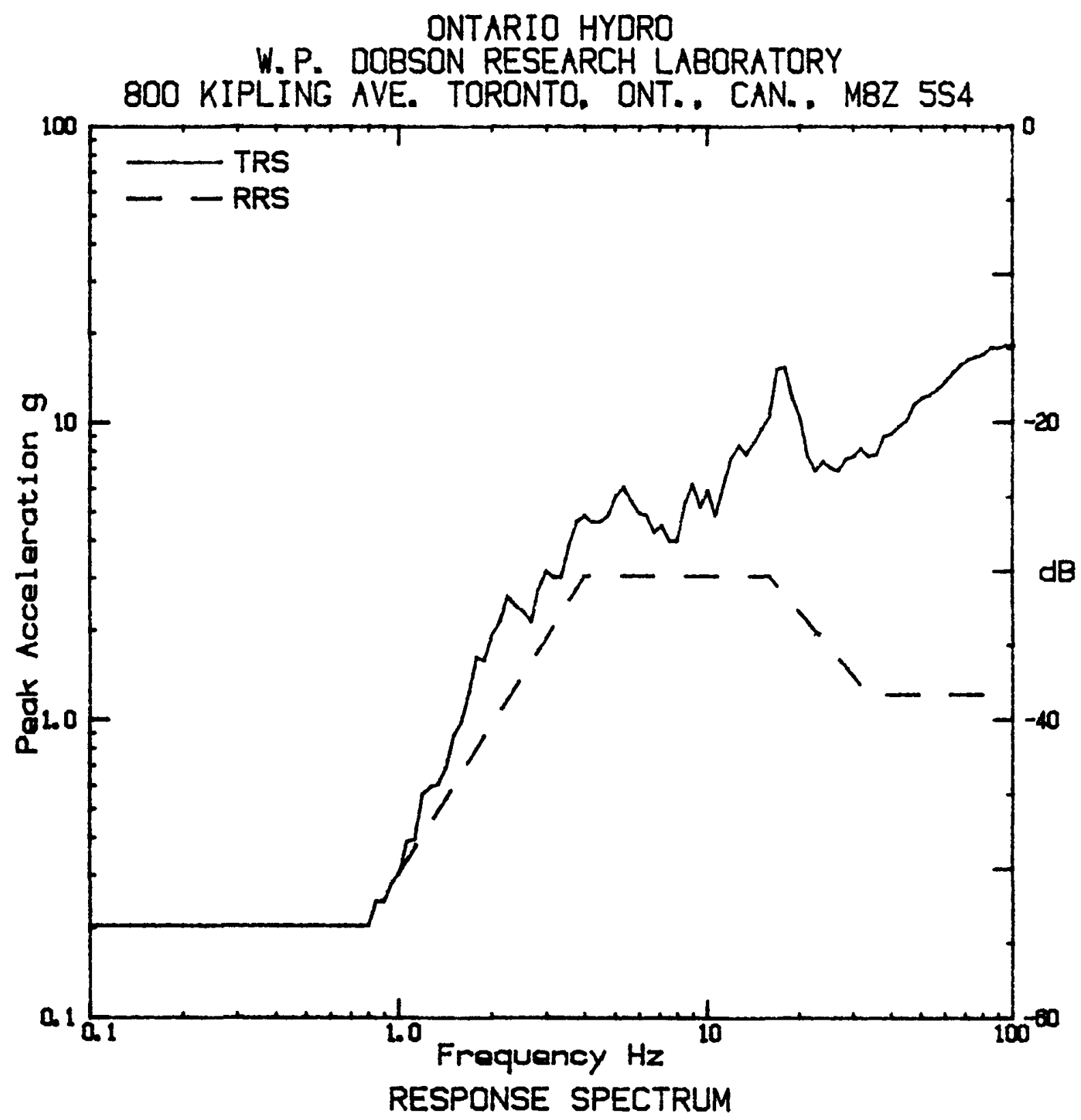

FIGURE 22

TEST ITEM

station coll. Exide Model FHC-19, Sarial 35, Calvart Cliffe N.P.P.

PARTICULARS

July 23/84, Time 11:14, Temp('C) 23. Humidity(x) 53.

Proes (kPa) 100.2. Graph 5221

SPECIFICATIONS

Spece IEEE 501. Conditione operating, 3 hour rate epon 7

ANALYSIS

Typa Maximax, Damping (X) 5, B. Wo $1 / 12$ Octaves, Axis $X_{*}$ Shaker tri-axial. ZPX $=1.229$

ACCELEROMETER

Wilcoxon Sorial 5901. Range dB49, Location top-cell terminal. Channel 4 


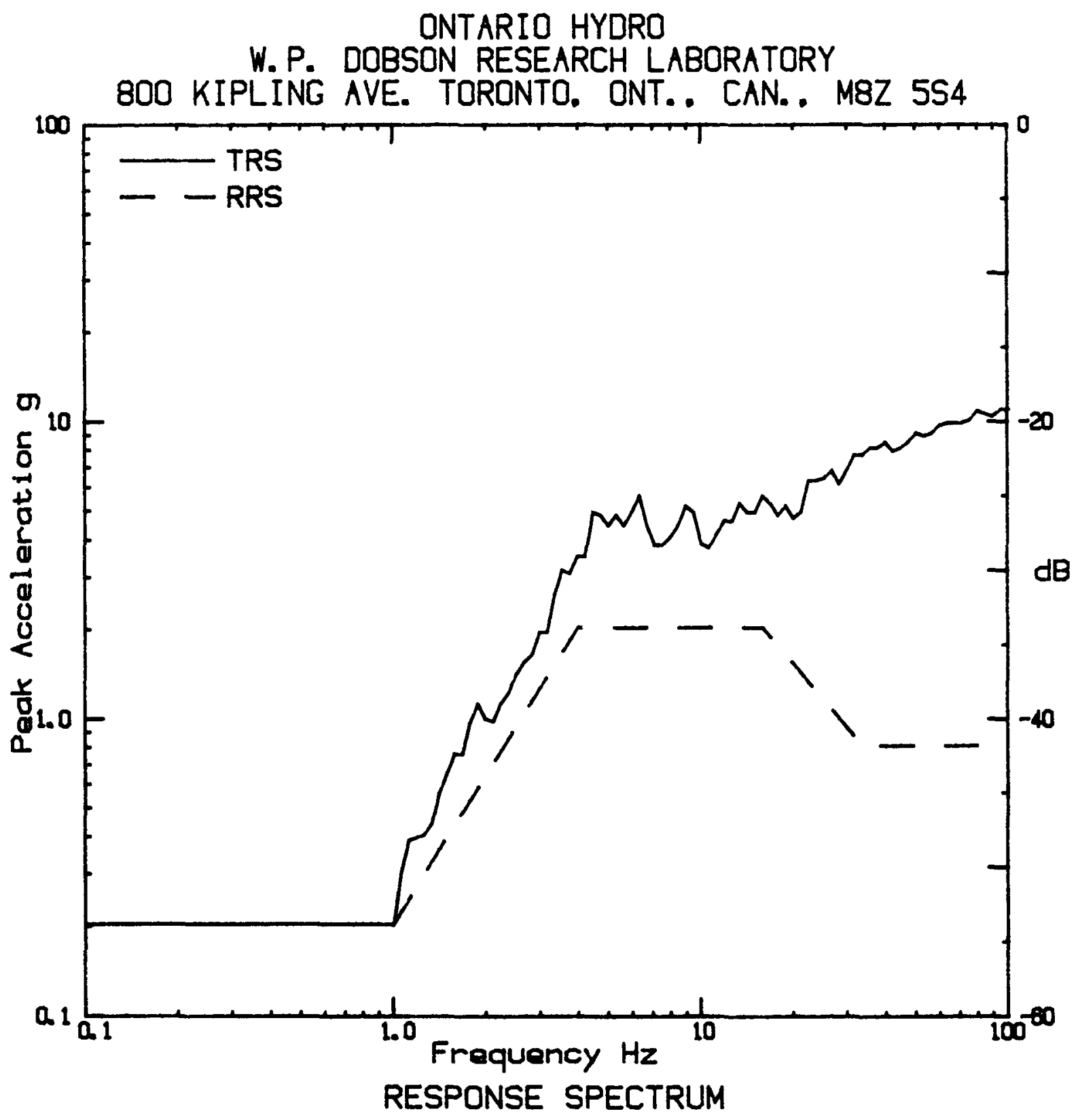

FIGURE 23

TEST ITEM

otation cell. Exide, Model FHC-19, Sorial 35, Calvert Cliffo N.P.P.

PARTICULARS

July 23/84, Time 11:14, Tenp('C) 23, Humidity (z) 53.

Proes (kPa) 100 2. Groph 5222

SPECIFICATIONS

Spece IEEE 501. Conditions operating : 3 hour rate, epan 7

ANALYSIS

Type Maximax, Damping (z) 5, B. W. = 1/12 Octaves, Axis $Y_{0}$ Shaker tri-axial, ZPX =.82g

ACCELEROMETER

Wilcoxon, Sarial S754, Range dB49, Location top-cell terminal. 


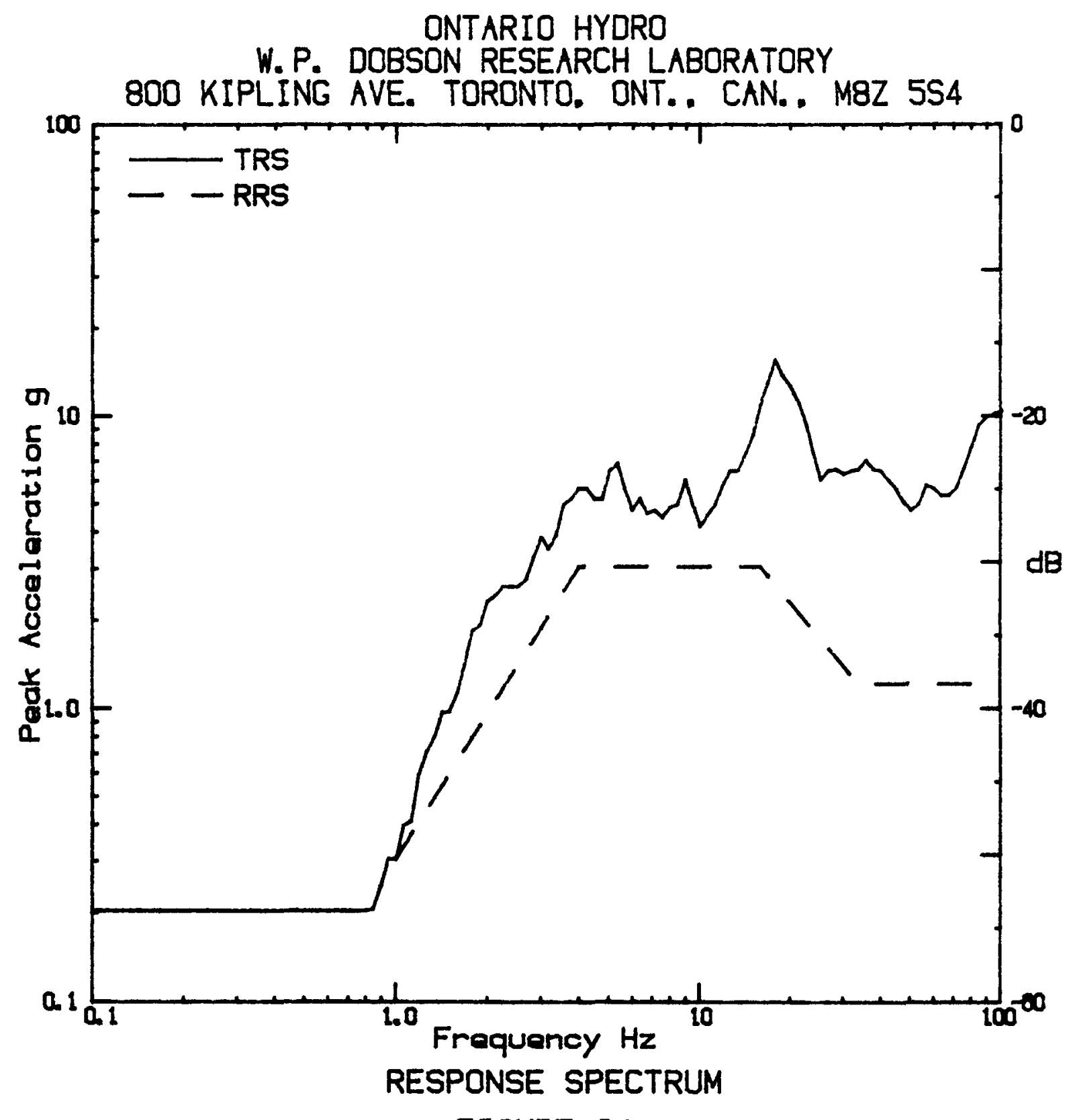

FIGURE 24

TEST ITEM

otation coll. Exide, Modal FHC-19, Sorial 35, Calvert Cliffe N.P.P.

PARTICULARS

July 23/84, T1m 11:14, Tomp('C) 29. Hunidity(C) 53,

Prave (kPa) 100.2, Groph 5223

SPECIFICATIONS

Spece IEEE 501. Conditione operating I 3 hour rate, epon 7

ANALYSIS

Type Maximax, Damping (S) 5, B. $W_{0}=1 / 12$ Octavee, Axis Z.

Shater tri-axial. $Z P X=1.22 g$

ACCELEROMETER

Vilcoxon Serial 5757. Range \&49, Location top-cell terminal. Chamel 6 

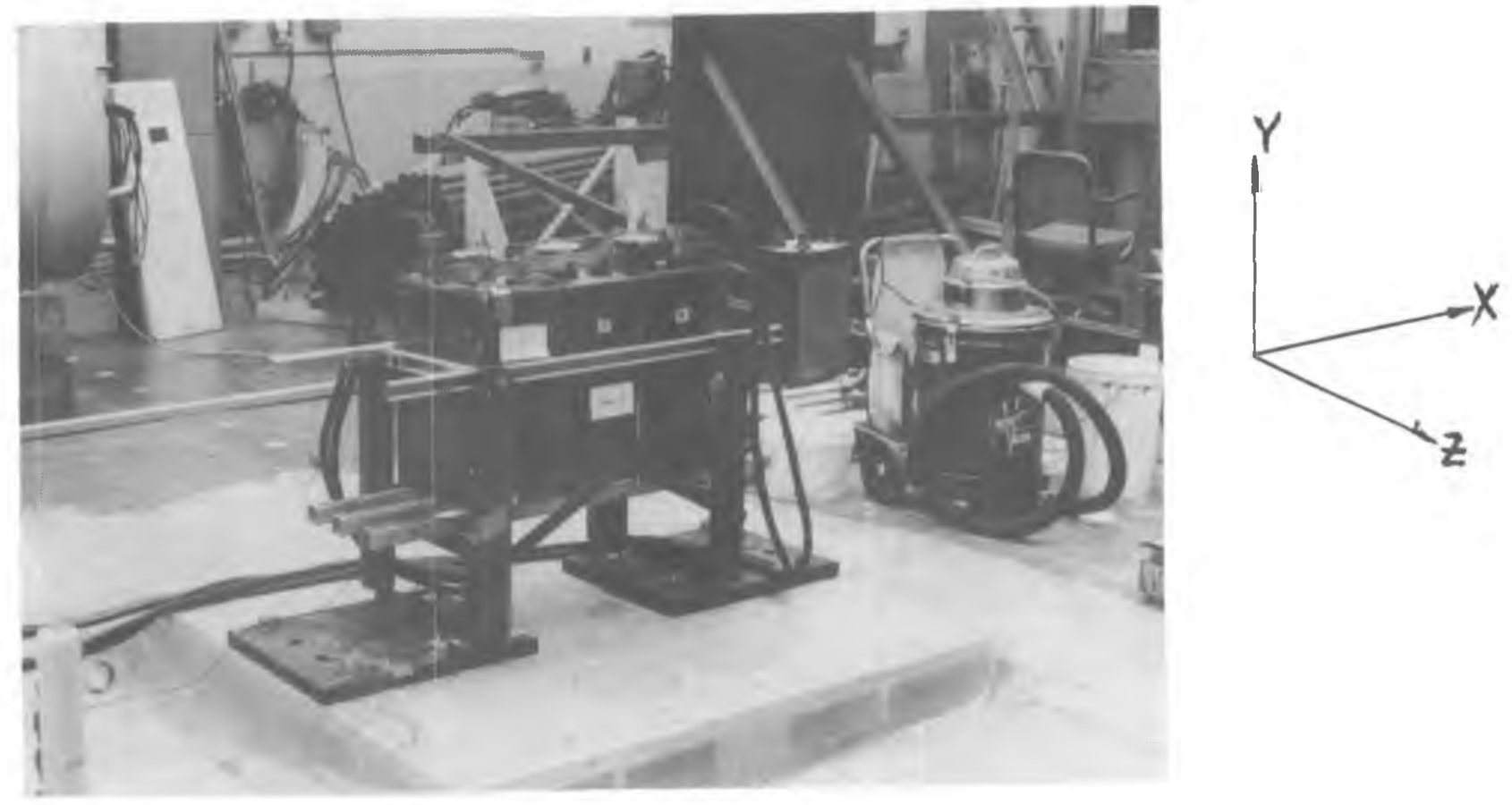

FIGURE 25A

THREE EXIDE MODEL FHC-19 CELLS WERE MOUNTED AS SHOWN ON THE TRIAXIAL SHAKER TABLE, THE TEST RACK IS SIMILAR IN CONSTRUCTION TO THE ONE USED AT THE FitzPATRICK N,P.P. THE ACCELEROMETERS ARE MOUNTED ON THE BASE AND CELL TERMINAL DURING THE TESTS, THE ACCELEROMETER DIRECTIONS ARE AS INDICATED. 


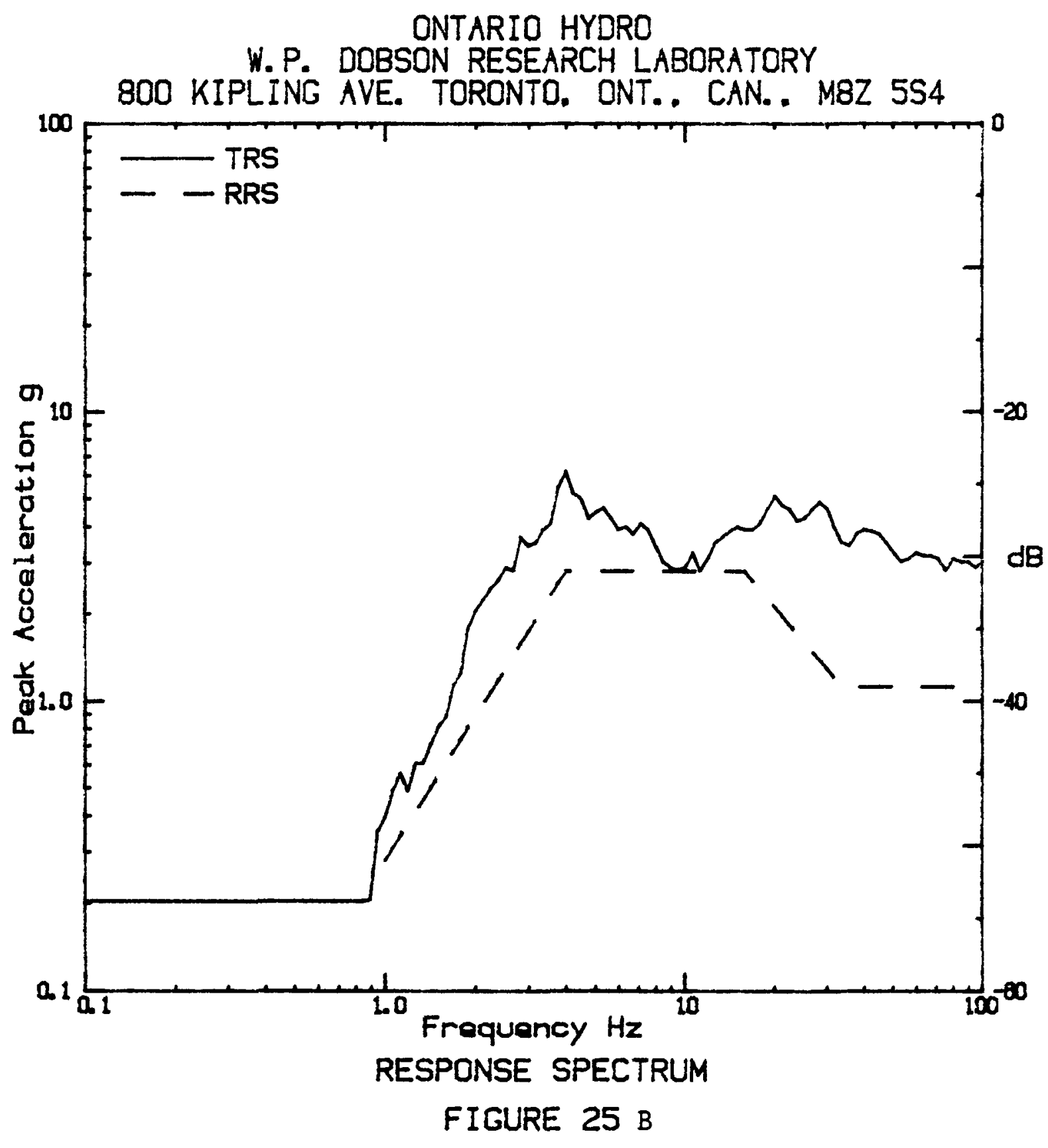

TEST ITEM

Station cells \& Rack, Exide, Modal FHC-19, Sarial 15, 23, 10, Calvert Cliffo N.P.P.

PARTICULARS

July 24/84, Time 23 44, Tamp('C) 23. Humidity $(\not)$ 55, Prese (kPa) 100 3, Groph 5248

SPECIFICATIONS

Spece IEEE 501, Conditions operating : 1 hour rate epan 7

ANALYSIS

Type Maximax, Damping (x)5, B. $W_{0}=1 / 12$ Dctoveen Axis $X_{0}$ Shaker tri-axial. ZPX $=1$. 13g

ACCELEROMETER

Wilcoxon, Serial 5771. Range dB49, Location base-mounting plate. Channel 1 


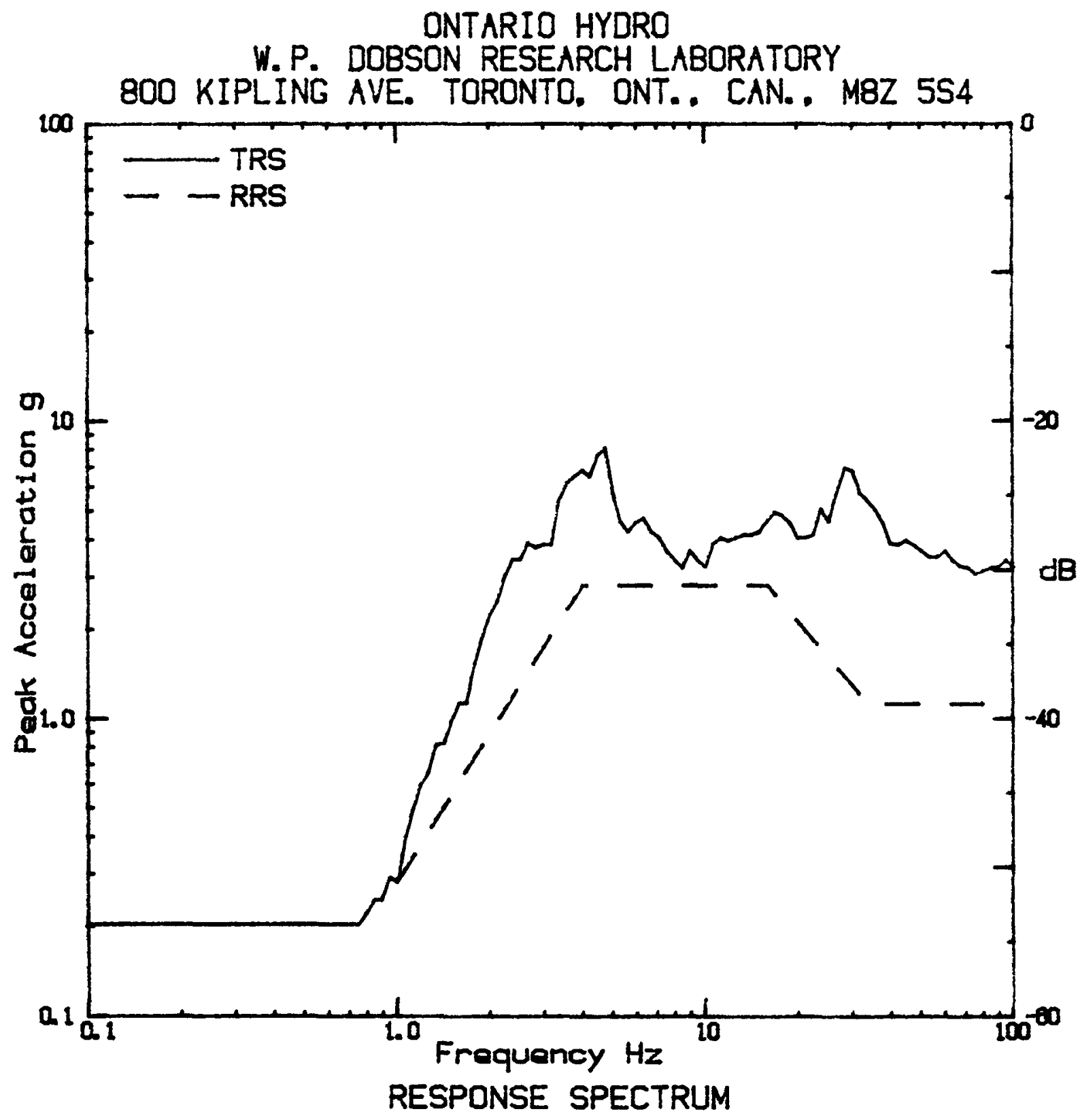

FIGURE 26

TEST ITEM

Station colls \& Rack, Exide, Modal FHC-19, Sorial 15, 23, 10, Calvert Cliffe N.P.P.

PARTICULARS

July 24/84. Tima 2 44, Temp('C) 23, Humidity ( ()$^{\prime}$ 55, Prose (kPa) 100. 3, Graph 5250

SPECIFICATIONS

Spece IEEE 501. Conditione oparating \& 1 hour rate, span 7

ANALYSIS

Type Maximax, Damping (D) 5, B. $X_{0}=1 / 12$ Dctaves, Axis Z. Shaker tri-axial. $Z P X=1.13 g$

ACCELEROMETER

Wilcoxon Sarial S297. Range AB49, Location base-mounting plate. Channel 3 


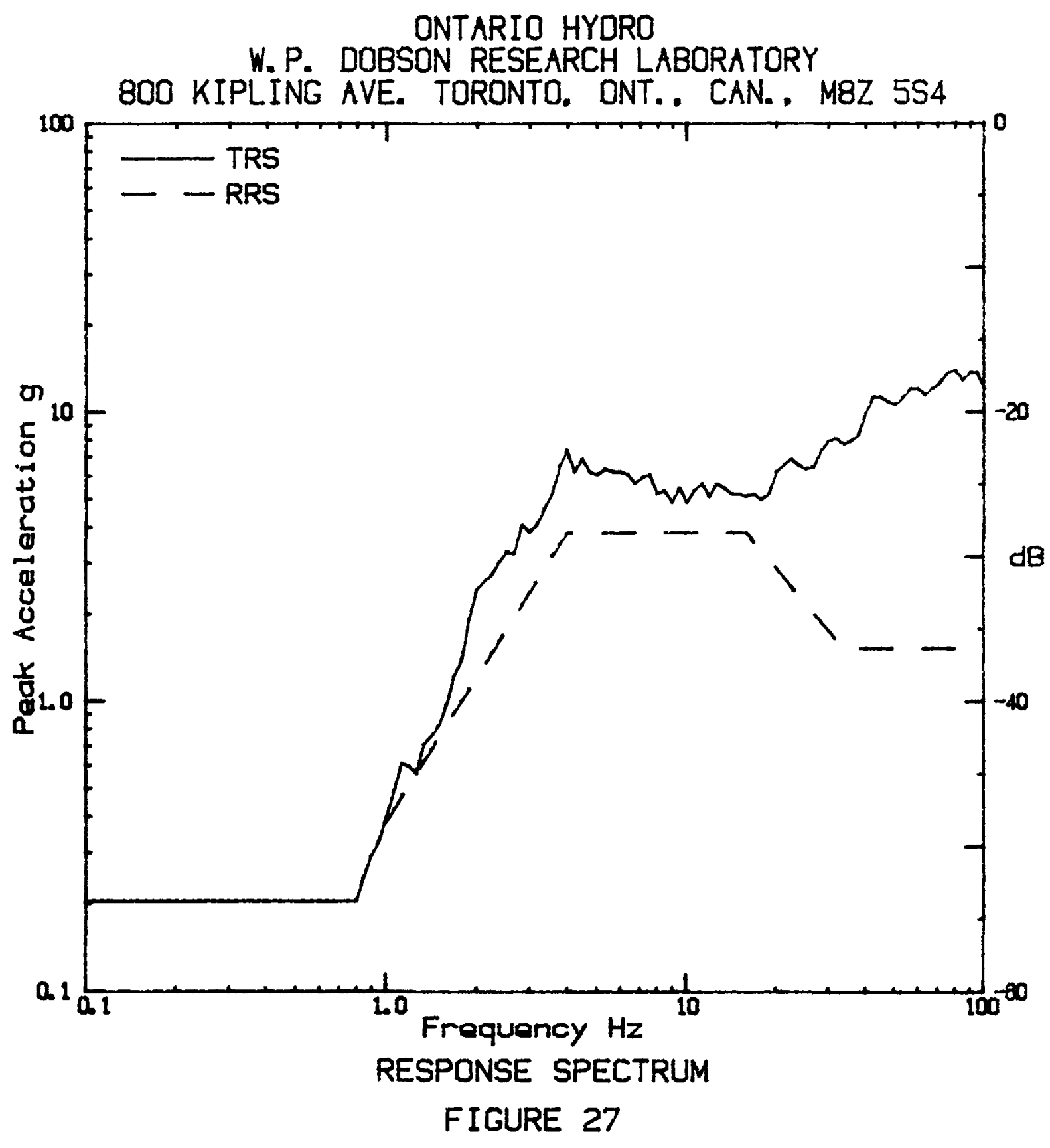

TEST ITEM

Station colls \& Rack, Exida Model FHC-19. Sorfal 15, 23, 10 Calvert Cilffe N.P.P.

PARTICULARS

July 24/94, Time 2a 44, Tamp ('C) 23. Humidity( () 55, Prees (kPa) 100. 3, Groph 5251. Record 0

SPECIFICATIONS

Spece IEEE 501. Conditione operating, 1 hour rate, spen 7

ANALYSIS

Type Maximax, Damping (x) 5 , B. W. $=1 / 12$ Dctaves, Axis $X_{0}$ Shaker tri-axiol. ZPX $=1.53 \mathrm{~g}$

ACCELEROMETER

Wilcoxon Sarial S901. Range dB49, Location top-cell torminal. Channal 4 


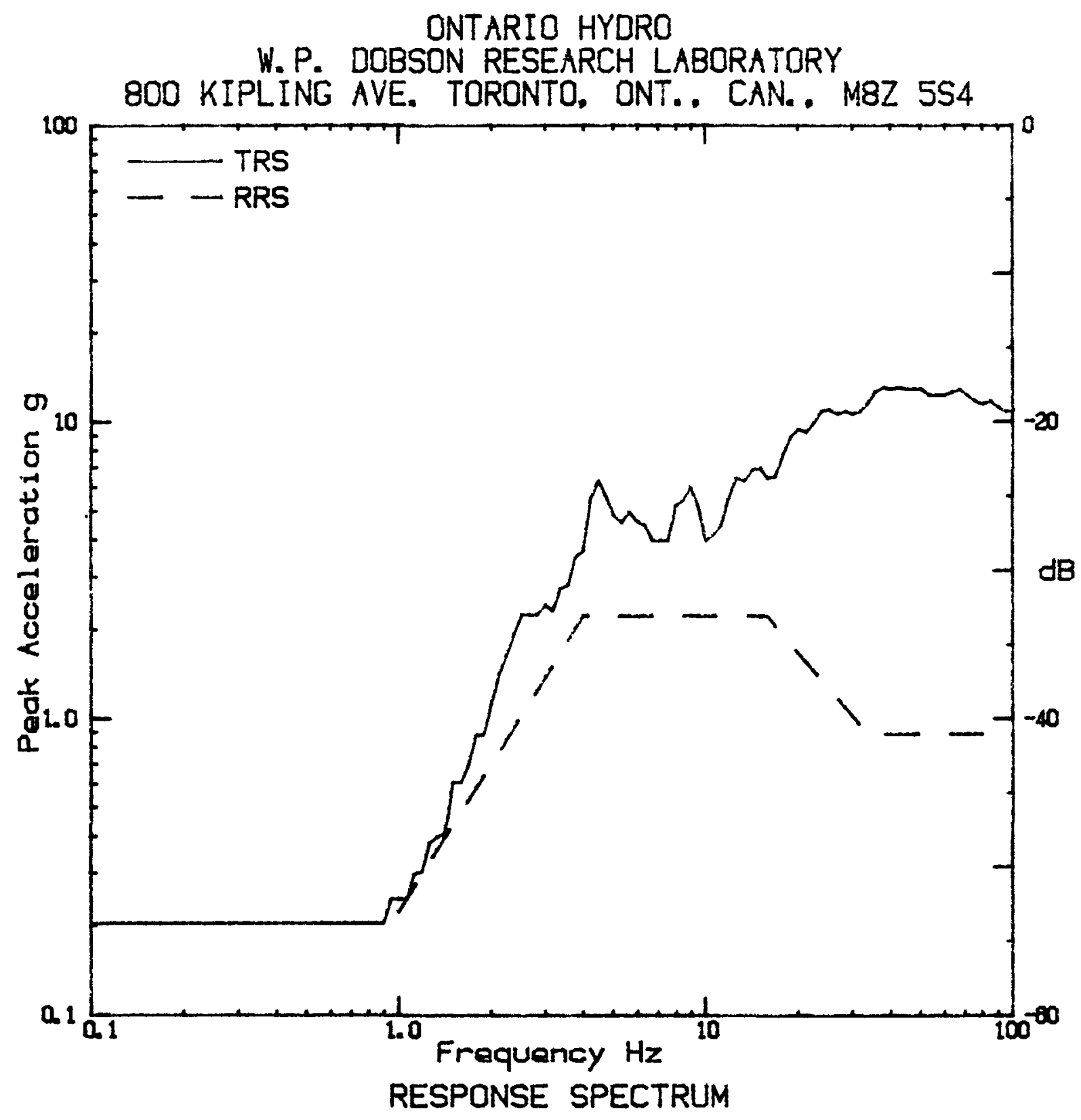

FIGURE 28

TEST ITEM

Station cells \& Rack, Exide, Modal FHC-19, Serial 15, 23, 10 Calvart Cliffs N.P.P.

PARTICULARS

July 24/84, Tima 24 44. Tomp('C) 23. Humidity(z) 55. Prees (kPo) 100. 3. Graph 5252. Record 0

SPECIFICATIONS

Spece IEEE 50\%. Conditione operating, 1 hour rate span 7

ANALYSIS

Typa Maximax, Damping (z)5, B. W. = 1/12 Dctaves, Axis Y.

Shaker tri-axial. ZPX $=.89 \mathrm{~g}$

ACCELEROMETER

Wilcoxor, Sarial 5757. Range d849, Location top-cell torminal. Channal 5 
ONTARIO HYDRO

W. P. DOBSON RESEARCH LABORATORY

800 KIPLING AVE. TORONTO. ONT. , CAN.. M8Z $5 S 4$

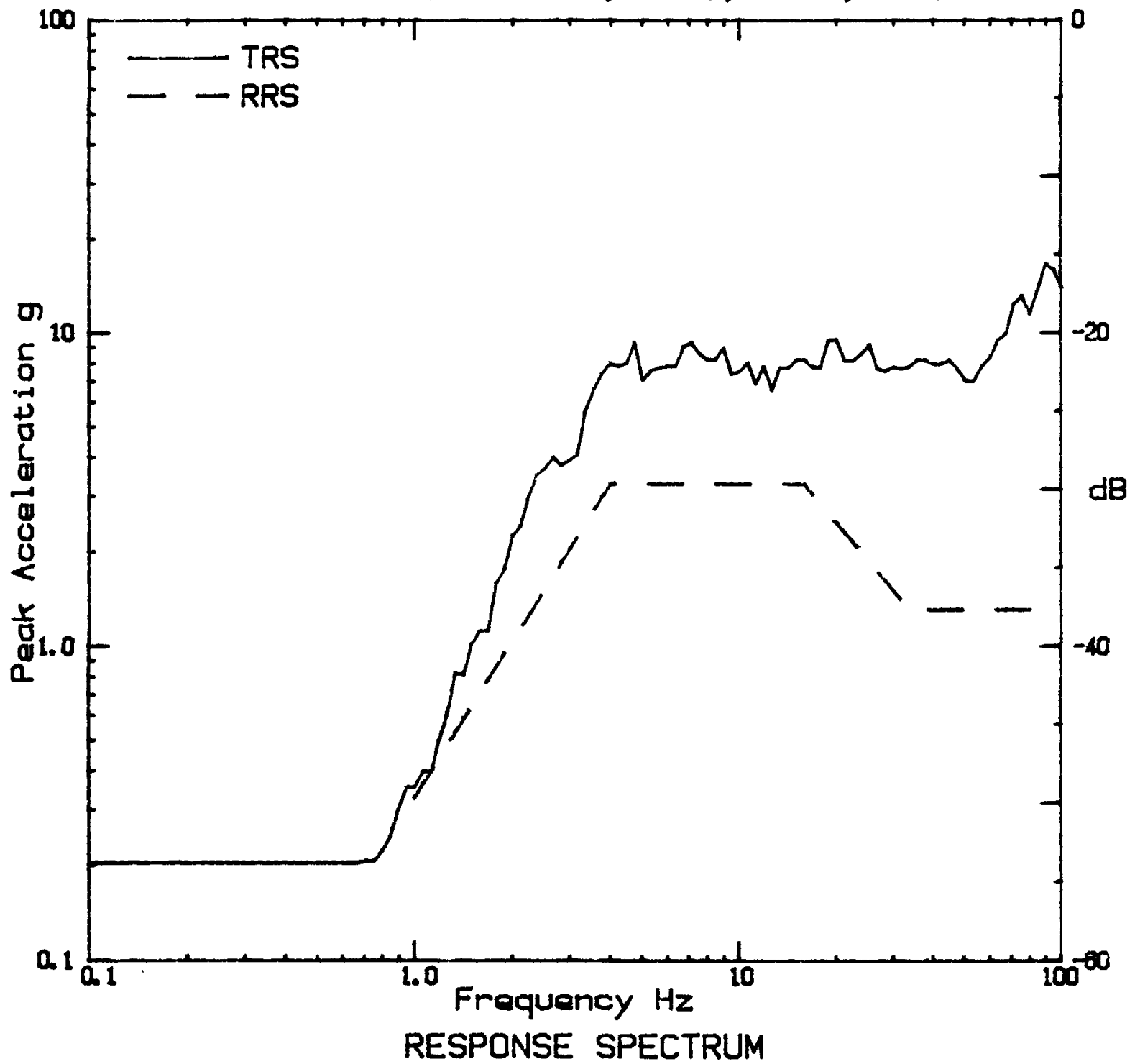

FIGURE 29

TEST ITEM

Station colls \& Rack, Exide, Modal FHC-19, Sarial 15. 23, 10 Calvart Cliffe N.P.P.

PARTICULARS

July 24/84. Time 2, 44, Temp ('C) 23. Humidity(x) 55. Preos (kPa) 100. 3. Graph 5253. Record 0

SPECIFICATIONS

Space IEEE 501. Conditione operating, 1 hour rate, span 7

ANALYSIS

Type Maximax, Damping (z)5, B. W. = $1 / 12$ Dctaves, Axis Z. Shaker tri-axial. ZPX=1. 3ig

ACCELEROMETER

Wilcoxon, Serial 5754, Range dB49, Location top-cell terminal. Channel 6 
APPENDIX E

Seismic Re-Testing of Calvert Cliffs

Nuclear Power Plant Batteries

at Increased Accelerations

D. A. Black

G. D. Paulsen

Ontario Hydro Research Division 
To Mr. B.A. Oliver

Manager

Electrical Design

Design \& Development

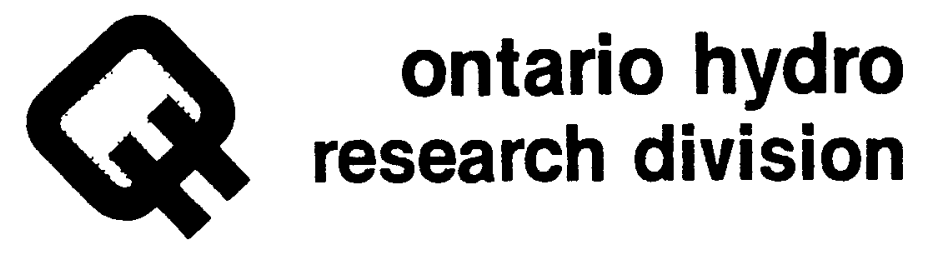

SEISMIC RE-TESTING OF CALVERT CLIFFS NUCLEAR POWER PLANT BATTERIES AT INCREASED ACCELERTION

D.A. Black and G.D. Paulsen

Two Exide Cells were seismically tested to IEEE and AECL Specifications. These cells were previously tested. This report describes the test procedure followed, the test equipment used, and gives the results of the tests.

\subsection{INTRODUCTION}

The two cells were seismically tested to IEEE $344 / 1 /$ and IEEE $501 / 2 /$ specifications. Date of test, specimen description, test facility name and location, test data and test temperature, humidity and pressure are recorded on each of the response spectrum curves. These curves also show the conditions of the test, the type of analysis, the accelerometers used, the direction of the test, and the axis analysed. All tests were analysed using 58 damping and the maximax shock spectrum. The tests performed were tri-axial tests as defined in IEEE 344. The shaker inputs were psuedo-random with a duration of $30 \mathrm{~s}$. All technical terms used in this report are defined by Harris/3/.

\subsection{SAMPLES}

The two cells were removed from Calvert Cliffs Nuclear Power plant after 10 years of service. The cells were seismically tested previously/4/ to moderate vibration levels. The cells tested were identified as follows:

1) Station Cell; Exide; Model FHC19; Cell \#51.

2) Station Cell: Exide; Model LCU19; Cell \#23.

\begin{tabular}{|c|c|c|c|c|c|}
\hline $740624-268-40150$ & $740624-268-40150$ & $f^{f i t e}$ & 824.4 & January 17,1985 & $\begin{array}{l}\text { report no. } \\
85-56-\mathrm{P}\end{array}$ \\
\hline
\end{tabular}




\subsection{TEST EQUIPMENT}

\subsection{Equipment Used}

3.1.1 Shaker Control Equipment

1. MTS 436 control units

2. MTS 406.11 controllers

3 MTS hydraulic pumps

4. Ontario Hydro noise generators and filters

5. Ontario Hydro tri-axial shaker table.

\subsubsection{Analysis}

1. Columbia Model 9000 amplifiers and matching Wilcoxon M-408 accelerometers.

Amplifier

Serial No

$\begin{array}{ll}368 & 1632\end{array}$

$368 \quad 1633$

$368 \quad 1634$

$368 \quad 1635$

36.81636

$\begin{array}{lll}368 & 1637\end{array}$

3691638

3691639

3691640

3691641

3691642

3691643
Accelerometer

Serial No

$\mathrm{S} 893$

5297

5901

S369

S753

S754

S756

S757

S759

S760

S761

S771

2. SE tape recorder Model 7000A, Serial No 547.

3. Tektronix 5113 dual beam storage oscilloscope, KS3681.

4. Spectral Dynamics 13231 Shock Spectrum Analyser, Serial No 27.

5. Spectral Dynamics 13191 Transient Memory, Serial No 29.

6. Ontario Hydro transmissibility circuit.

7. Watanabe WX4400 X-Y Recorder, Serial No 83010070.

8. Hewlett-Packard 7046A X-Y1-Y2 Recorder, Serial No 1914 A05842.

9. Spectral Dynamics 5012lL Tracking Filter, Serial No 171. 
10. Spectral Dynamics SD122L Tracking Filter, Serial No 370.

11. Honeywell 1858 oscillograph, Serial No 2649JF78.

12. Nicolet Scientific Corp, Model 660A Dual Channel FFT Analyzer, Serial No 9866226.

13. Hewlett-Packard Model 7470A Plotter, Serial No $2210 \mathrm{~A}-12990$.

3.1.3 Calibration Equipment

1. Bruel and Kjaer Type 3506, Serial No 877022 Accelerometer Calibration set which includes Type 2626, Serial No 842947 and Type 83055, Serial No 858627, traceable to NBS.

2. General Radio 1557-A vibration calibrator, Serial No 2379 .

3. Data Precision 2440 digital voltmeter, Serial No 5733, traceable to NBS.

4. Data Precision 248 digital voltmeter, Serial No 8583, traceable to NBS.

4.0 TESTS AND PROCEDURES

4.1 Calibration Procedure

Accelerometers and amplifiers are calibrated using the back-toback calibration procedure. The reference accelerometer was mounted on the vibration calibrator with the wilcoxon accelerometer. Using $100 \mathrm{~Hz}$ sine wave vibration of approximately $1 \mathrm{~g}$, the sensitivity of the Columbia amplifiers was set to give 500 $\mathrm{mV} / \mathrm{g}$ output. The outputs were measured using the digital voltmeter. By using the same voltmeter for both the reference and the Columbia amplifiers, slight differences in voltmeters need not be considered. Since the voltmeter measures true RMS voltages, the waveshapes of the $100 \mathrm{~Hz}$ signals were compared on the oscilloscope. This ensures that the signals are equivalent.

\subsection{Test Setup and Procedures}

Each cell was mounted as shown in Figure 01A. A cell was clamped into the test jig using 4 corner clamps and 8-1/2" threaded rods. The wooden block was inserted as a spacer. Each cell was subjected to two vibration tests. The tests were nominally at 858 and 1008 of the shaker's limit. During the tests, the cells were loaded and monitored by Chemical Research/5/. 


\subsection{Vibration Tests}

The shaker consists of random generators and hydraulic actuators which are capable of driving the shaker in three directions simultaneously. The shaker has the following limitation in each axis:

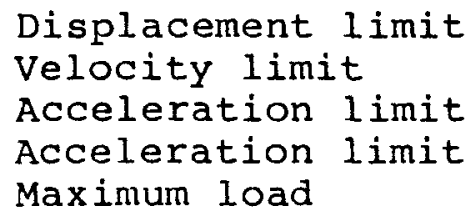

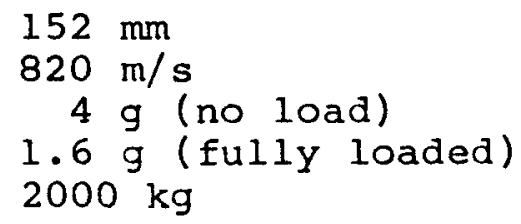

\subsection{RESULTS}

The test results for the two cells are given in Figures 0lB through 12. There was no visible structural damage in either cell as a result of the tests. The cells were vibration tested as reported in Table $I$.

\subsection{CONCLUSIONS}

The cells survived the tests with little spillage of electrolyte and no obvious structural damage.

\section{Approved:}

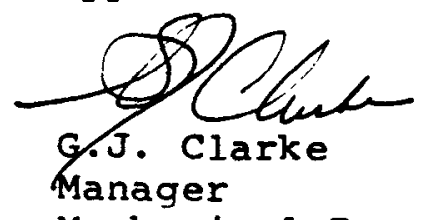

Mechanical Research Dept
Submitted:
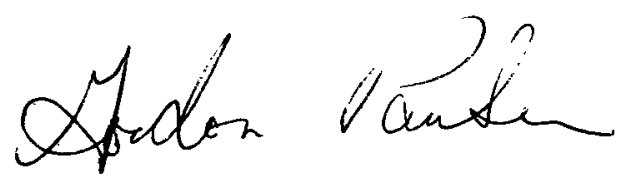

G.D. Paulsen Technologist Mechanical Testing and Development Section

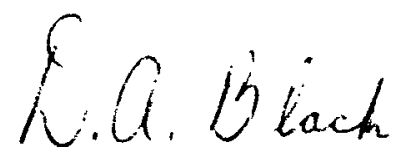

D.A. Black Engineer Mechanical Testing and Development section

GDP : DAB : sf 


\section{REFERENCES}

1. The Institute of Electrical and Electronic Engineers Inc. IEEE 344. Qualification of Class lE Equipment for Nuclear Power Generating Stations. New York. 1975.

2. The Institute of Electrical and Electronic Engineers Inc. IEEE 501. IEEE Recommended Practices for seismic Qualification of Relays.

3. Harris, Cyril M., and Charles E. Crede. "Shock and Vibration Handbook". Second Edition. McGraw Hill Book Company. Toronto. 1976 .

4. Black, D.A. and G.D. Paulsen. "Seismic Testing of Calvert Cliffs Nuclear Power Plant Batteries." Ontario Hydro Research Report 84-418-P. December 11, 1984.

5. Janis, J. "Seismic Testing of North Anna and Calvert Cliffs Nuclear Power Station Batteries - Second Stage High Table Accelerations." Ontario Hydro Research Report C85-019-P. January, 1985.

\section{DISTRIBUTION}

Mr. B.A. Oliver

Mr. W.J. Janis

Dr. J.D. Tulk (10)

Mr. G.D. Paulsen

Mr. D.A. Black

official Record
Des \& Dev - Generation, H12G5 Chemical Research

Mechanical Research

Mechanical Research

Mechanical Research 


\section{TABLE I}

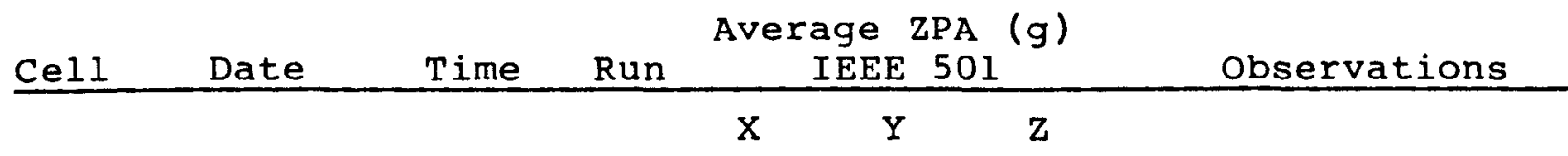

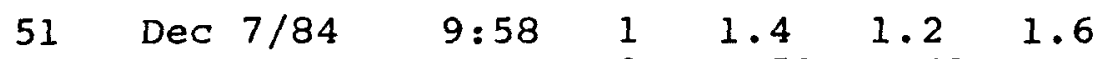

10:00 $21.59 \quad 1.42 \quad 1.48$ some leakage from vents.

$\begin{array}{lllllll}23 & \text { Dec } 7 / 84 & 1: 43 & 1 & 1.4 & 1.2 & 1.6 \\ 1: 45 & 2 & 1.65 & 1.31 & 1.56\end{array}$

Some lekage from vents. 


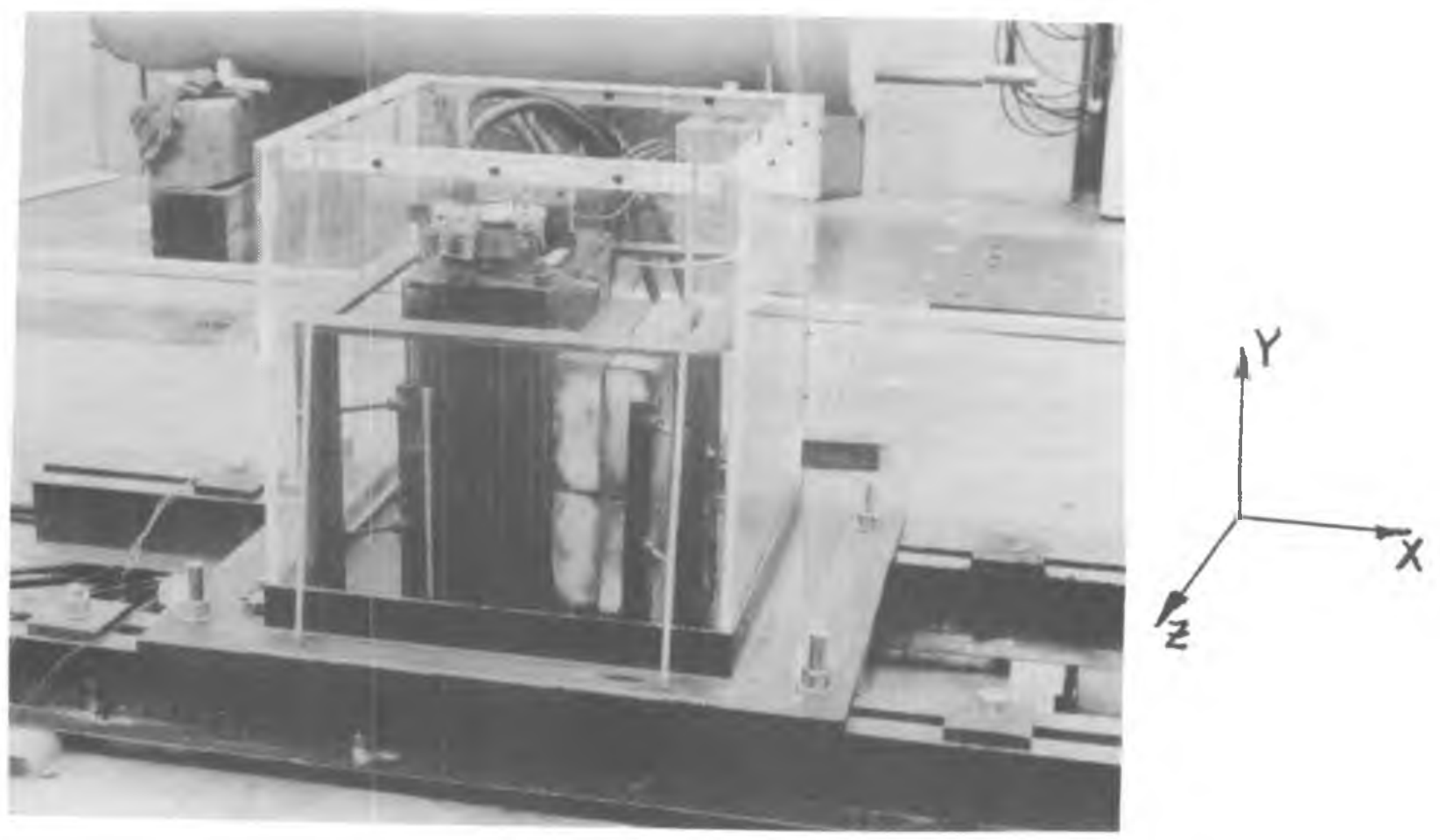

\section{FIGURE 01A}

EACH CELL WAS MOUNTED TO THE TRI-AXIAL SHAKER TABLE AS SHOWN, ACCELEROMETERS WERE MOUNTED TO THE BASE PLATE AND ONE TERMINAL. THE CELL WAS CONNECTED TO MONITOR VOLTAGE ACROSS THE TERMINALS AND DRAW A SPECIFIED CURRENT, THE AXES OF VIBRATION ARE SHOWN, 


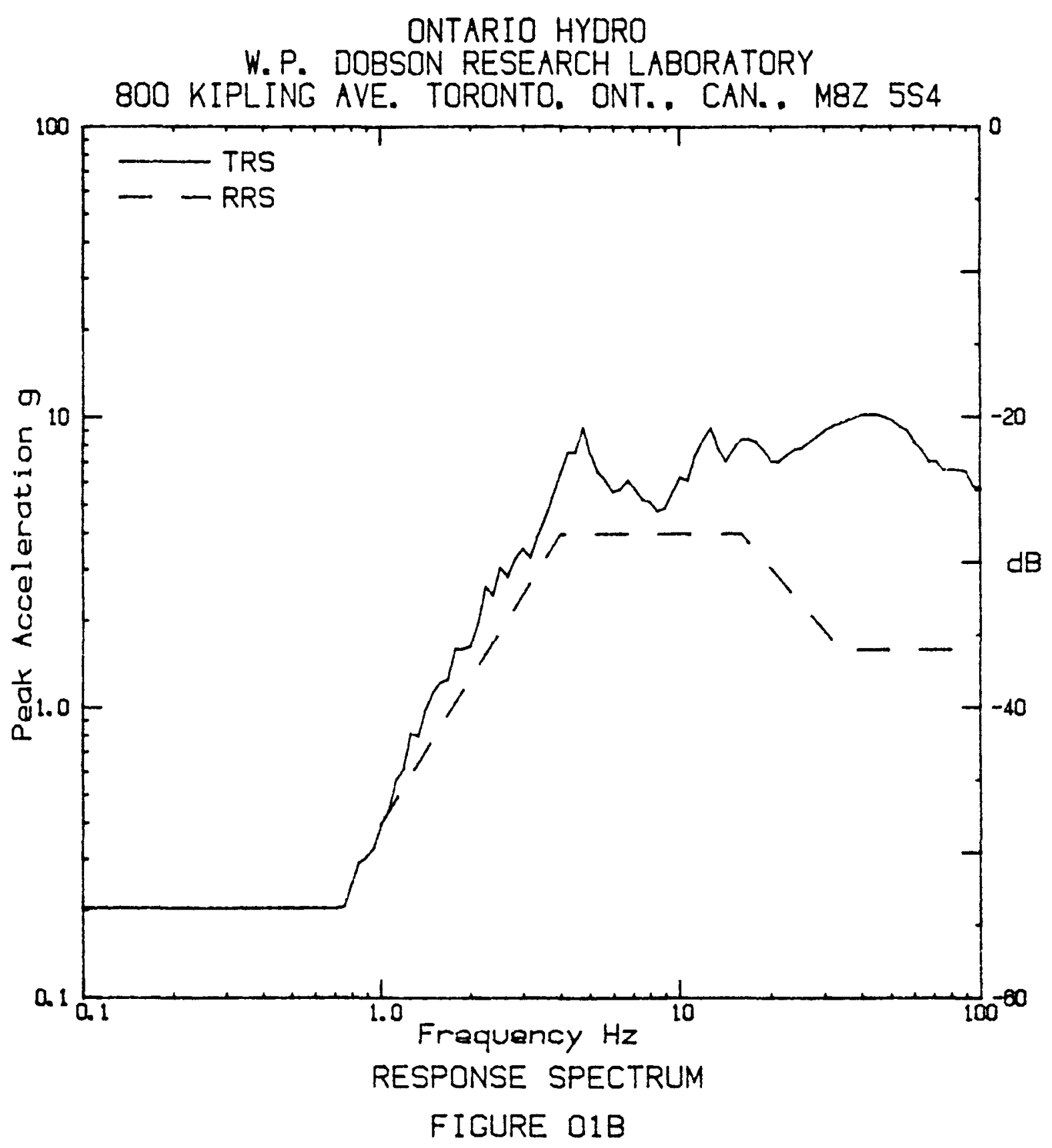

TEST ITEM

Station Call. Exida. Modal FHC 19. Call "51

PARTICULARS

Dec. 7/84. Time 10, 00. Tamp('C) 24. Humidity (z) 29. Prees (kPa) 100.5. Graph 5409. Record 0

SPECIFICATIONS

Spres IEEE 344, Conditions operating. table limit

ANALYSIS

Type Maximax. Damping (y) 5. B. $W_{0}=1 / 12$ Octaves, Axis X-base.

Shaker tri-axial, $Z P X=1.59 \mathrm{~g}$

ACCELEROMETER

Wilcoxon, Sarial 1214. Range d848, Location mounting plate. TT 722. Channel 1 
W.P. DOBSON RESEARCH LABORATORY

800 KIPLING AVE. TORONTO. ONT.. CAN.. M8Z $5 S 4$

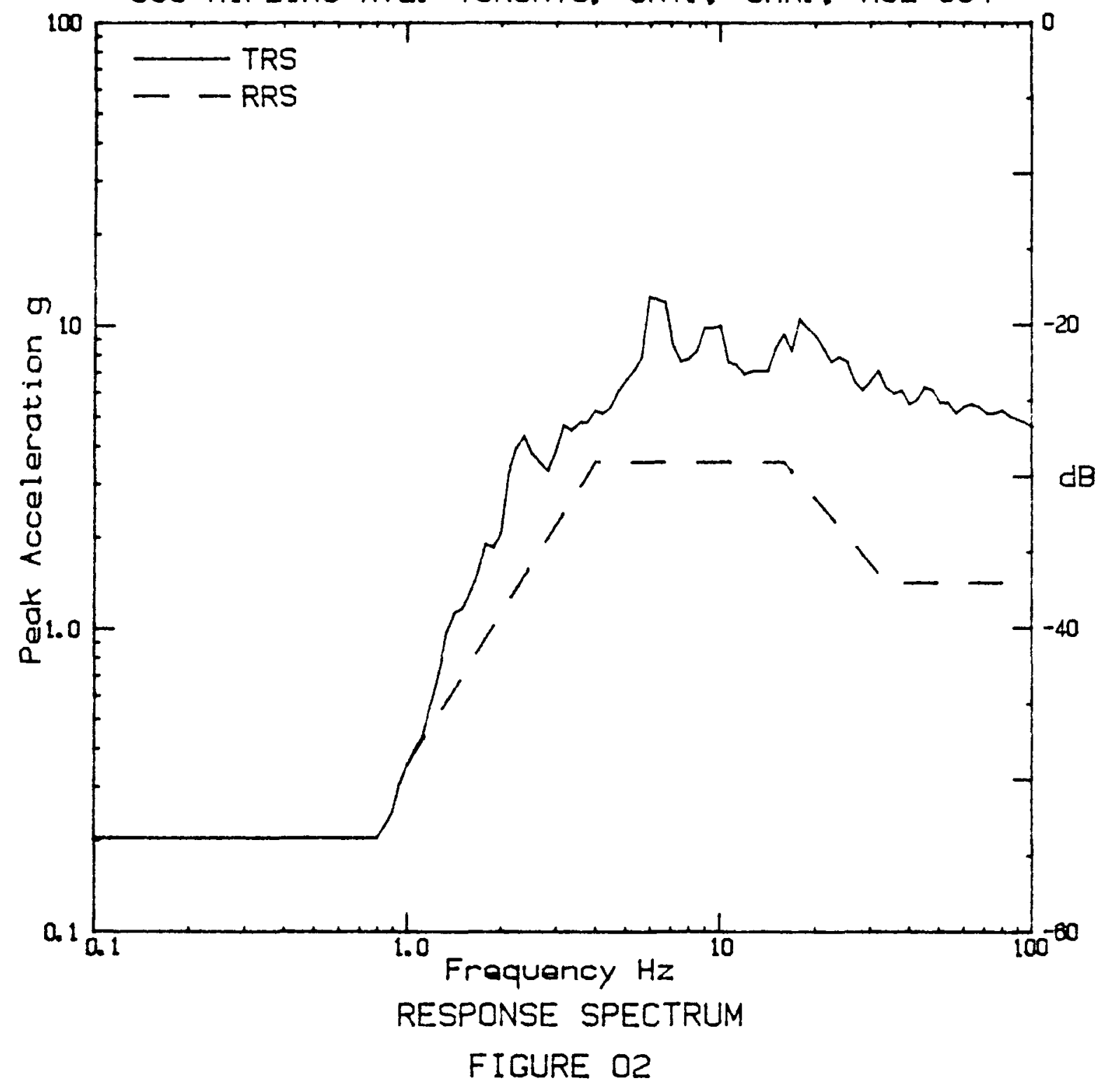

TEST ITEM

Station Call. Exide. Model FHC 19. Cell \#51

PARTICULARS

Dea 7/84. Time 10:00. Tamp('C) 24. Humidity( $(\zeta)$ 29. Press (kPa) 100. 5. Graph 5410. Record 0

SPECIFICATIONS

Specs IEEE 344. Conditions operating. table limit

ANALYSIS

Type Maximax. Damping (x) 5. B. W. = 1/12 Octoves, Axis Y-basa.

Shaker tri-oxial. $Z P X=1.42 g$

ACCELEROMETER

Wilcoxon. Serial 1215. Range dB48. Location mounting plate. TT 722. Channel 2 


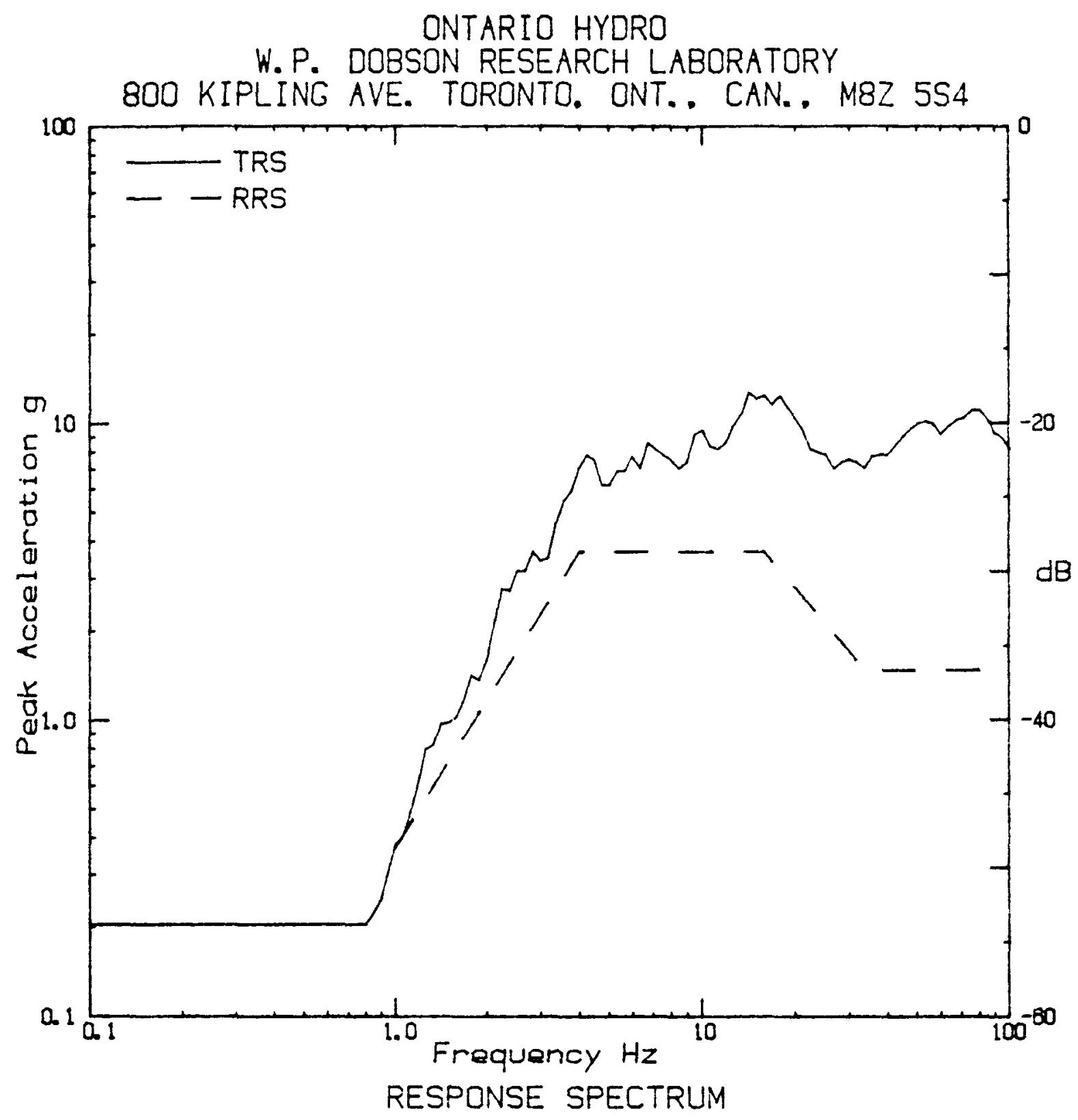

FIGURE 03

TEST ITEM

Station Cell. Exide. Model FHC 19. Call \#51

PARTICULARS

Dec. 7/84. Time 10, 00. Temp('C) 24. Humidity(Z) 29. Press (KPa) 100. 5. Graph 5411. Record D

SPECIFICATIONS

Specs IEEE 344. Conditions operating. table limit

ANALYSIS

Type Maximax. Damping (z) 5. B. W. = 1/12 Octaves. Axis Z-base.

Shaker tri-axial. $Z P X=1.48 \mathrm{~g}$

ACCELEROMETER

Wilcoxon, Serial 1213. Range d848, Location mounting plate. TT 722. Channel 3 


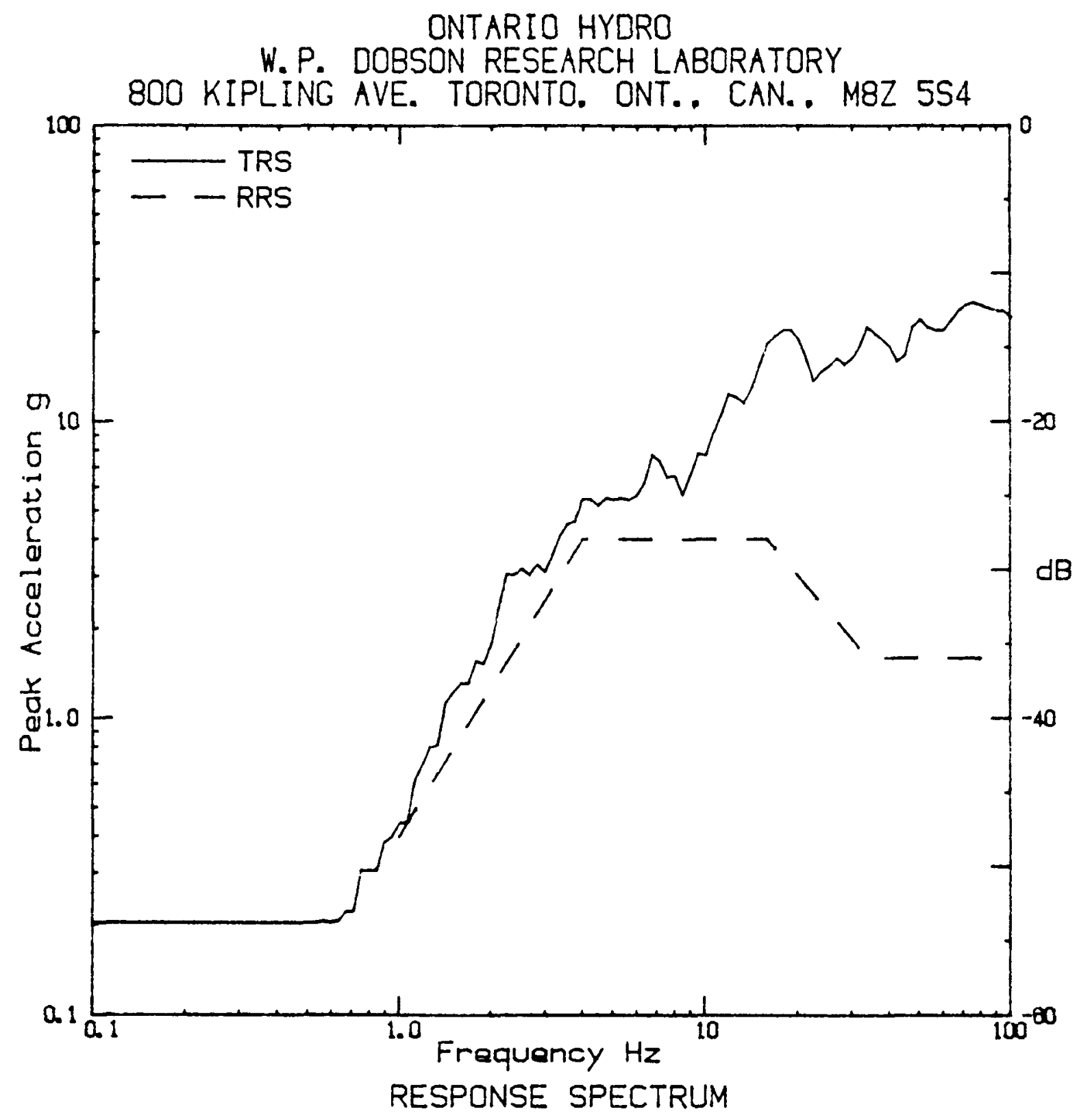

FIGURE 04

TEST ITEM

Station Call. Exida. Modal FHC 19. Call \#51

PARTICULARS

Dec 7/84, Time 10, 00, Temp('C) 24. Humidity ( $(x)$ 29. Press (kPa) 100.5. Graph 5412. Record 0

SPECIFICATIONS

Specs IEEE 344. Conditions operating, table limit

ANALYSIS

Typo Maximax. Damping (z) 5. B. W. $=1 / 12$ Octavos, Axis X-top. Shaker tri-axial. ZPX $=1.6 \mathrm{~g}$

ACCELEROMETER

Wilcoxon, Serial 5754. Range dB48. Location cell torminal. TT 722. Channel 4 


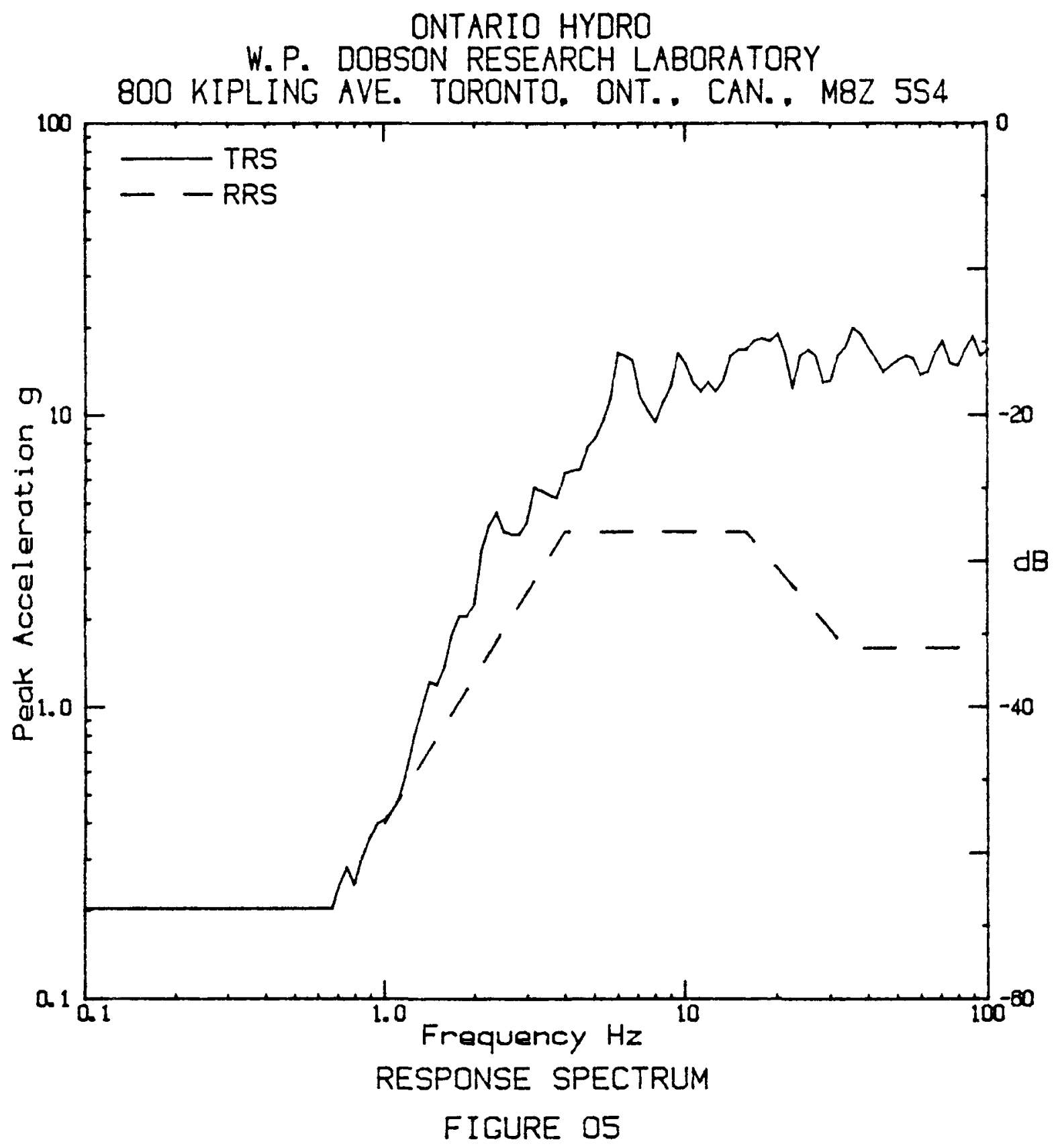

TEST ITEM

Station Cell. Exido. Modal FHC 19. Cell "51

PARTICULARS

Dec. 7/84. Time 10:00. Tamp $\left({ }^{\prime} \mathrm{C}\right) \backslash 24$. Humidity (z) 29. Prase $(\mathrm{KPa}) 100.5$. Graph 5413, Record 0

SPECIFICATIONS

Spece IEEE 344. Conditions operating table limit

ANALYSIS

Type Maximax. Damping (Z) 5, B. W. = $1 / 12$ Dctaves, Axis Y-top.
Shaker tri-axial. ZPX=1.6g

ACCELEROMETER

Wilcoxon, Serial 5757. Range dB48, Location cell terminal. TT 722.

Channel 5 


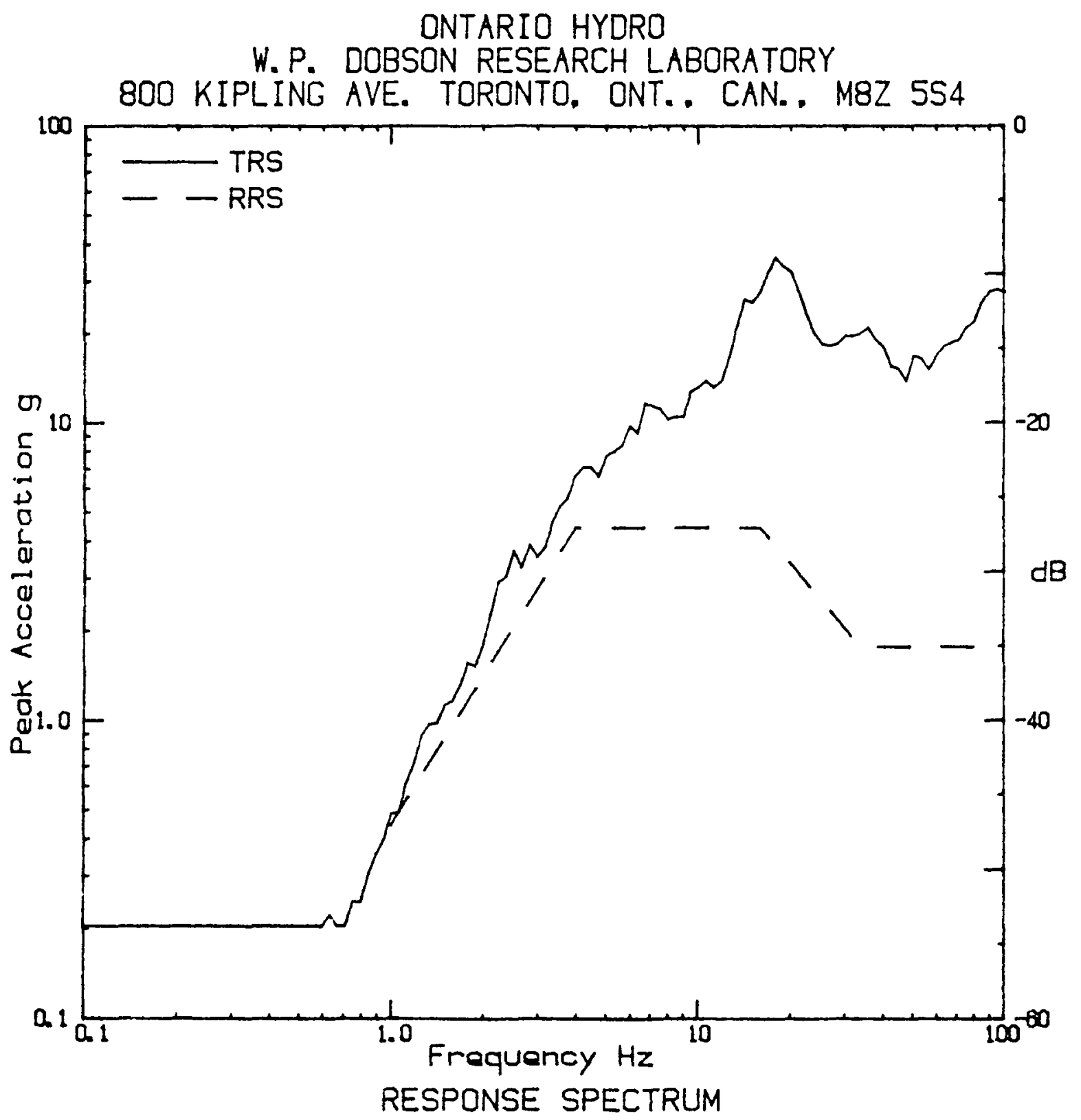

FIGURE O6

TEST ITEM

Station Call. Exida Modal FHC 19, Cell 451

PARTICULARS

Dec. 7/84, Time 10: 00. Tamp('C) 24. Humidity (z) 29. Prase (kPa) 100 5. Graph 5414. Racord D

SPECIFICATIONS

Specs IEEE 344. Conditions oparating tabla $11 \mathrm{mit}$

ANALYSIS

Type Maximax, Damping (z) 5. B. W. = $1 / 12$ Dctaves, Axis Z-top. Shaker tri-axial. $Z P X=1.78 \mathrm{~g}$

ACCELEROMETER

Vilcoxon. Sarial 5893. Range dB48. Location cell torminal. $\Pi 722$. Channel 6 


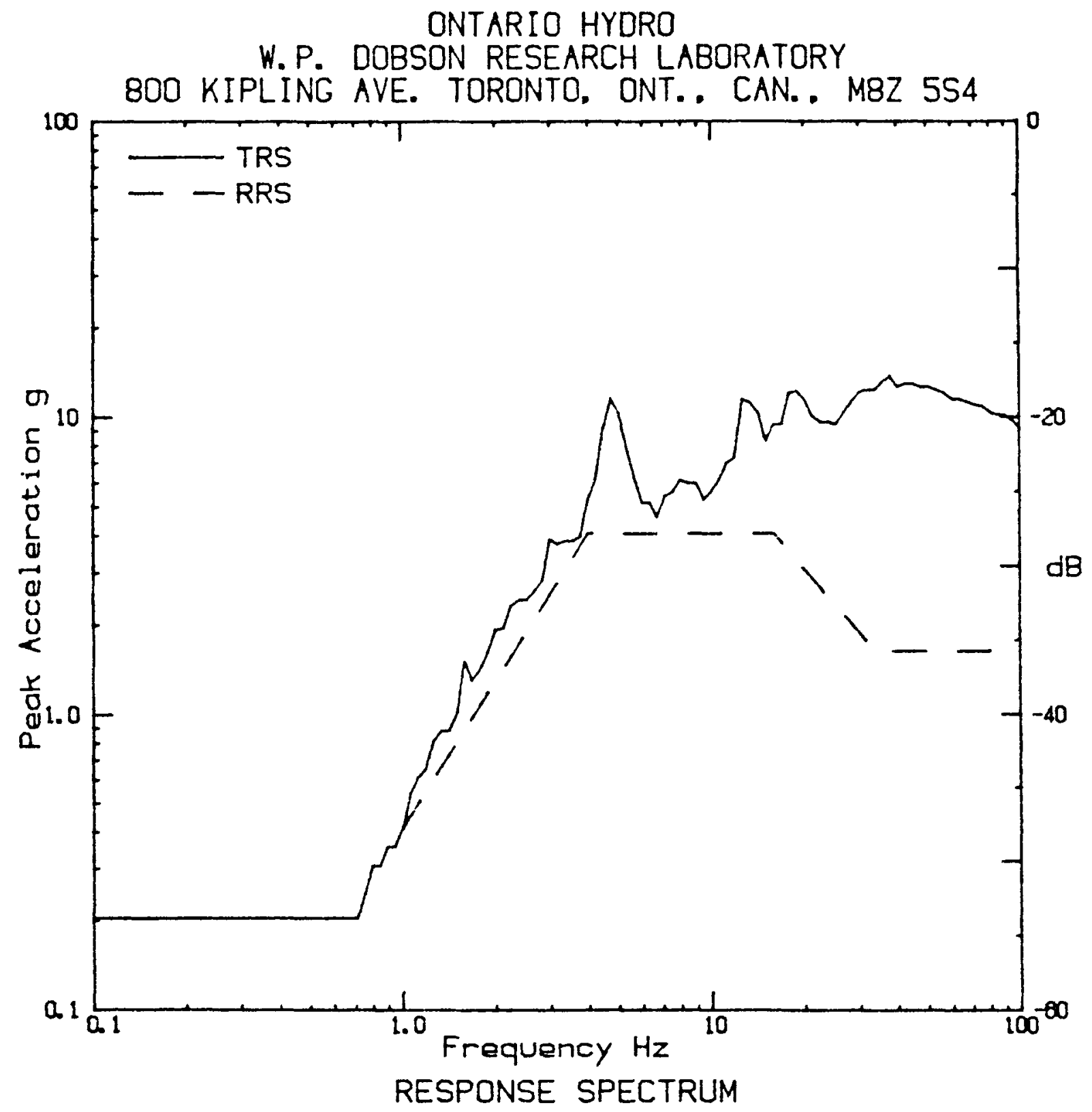

FICURE 07

TEST ITEM

Station Cell. Exido. Modal FHC 19. Cell *23

PARTICULARS

Dec. 7/84. Time 1, 45. Temp ('C) 24. Humidity(y) 29. Prass (kPa) 100. 5. Groph 5415. Record 0

SPECIFICATIONS

Specs IEEE 344. Conditions operating table limit

ANALYSIS

Type Maximax. Damping (x) 5. B. W. = $1 / 12$ Octaves, Axis X-base.

Shaker tri-axial. ZPX $=1.65 \mathrm{~g}$

ACCELEROMETER

Wilcoxon Serial 1214. Range d848. Location mounting plate. TT 726. Channel 1 
W. P. DOBSON RESEARCH LABORATORY

800 KIPLING AVE. TORONTO. ONT.. CAN., M8Z $5 S 4$

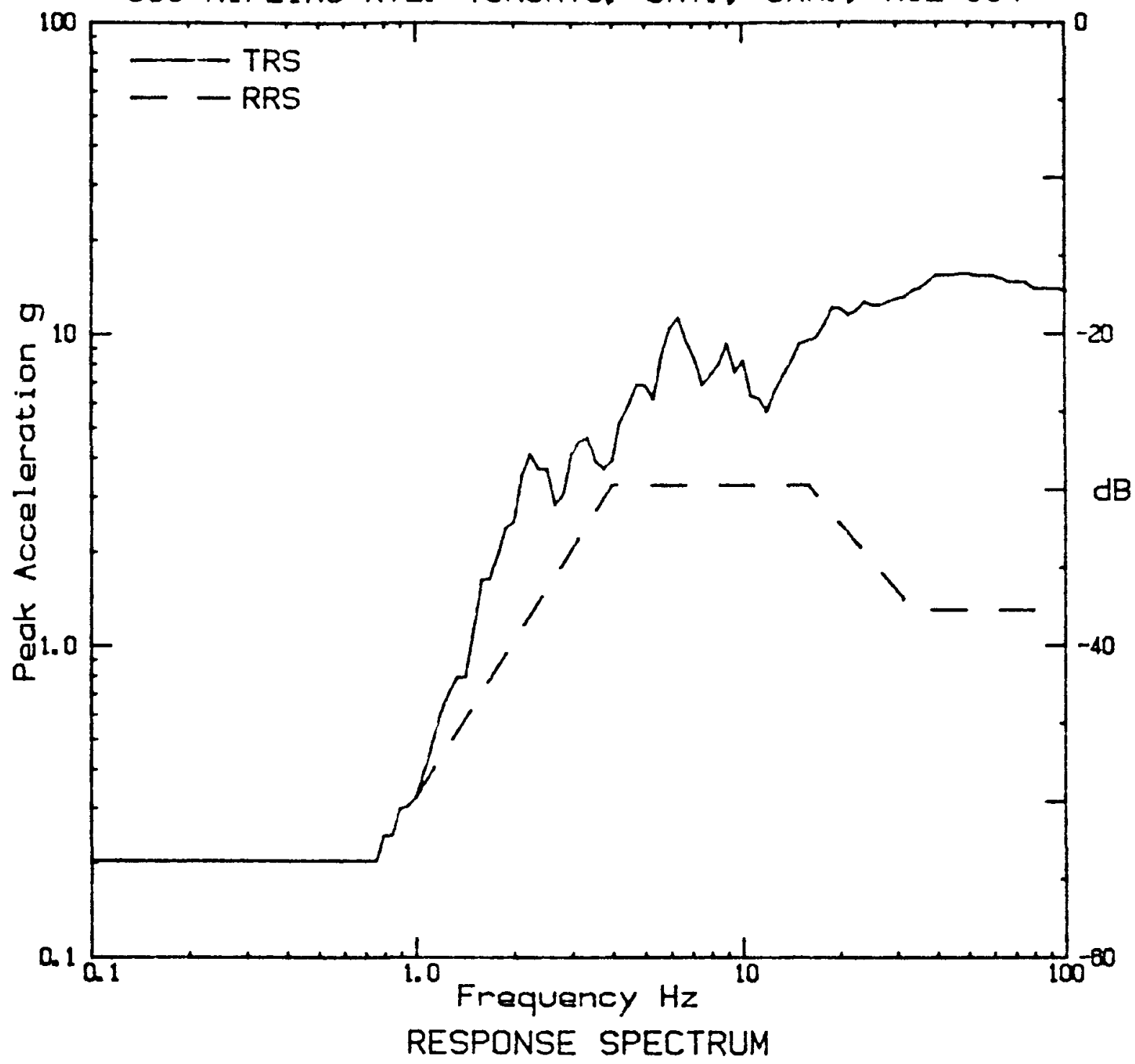

FIGURE 08

TEST ITEM

Station Cell. Exide. Modal FHC 19. Cell " 23

PARTICULARS

Dea 7/84. Time 1, 45. Tomp('C) 24. Humidity ( ()$^{\prime}$ 29. Pross (kPa) 100.5. Graph 5416. Record 0

SPECIFICATIONS

Specs IEEE 344. Conditions operating, table IImit

ANALYSIS

Type Maximax. Damping (x) 5. B. W. = 1/12 Octaves, Axis Y-base.

Shaker tri-axial. $Z P X=1.31 \mathrm{~g}$

ACCELEROMETER

Wilcoxon. Sarial 1215. Range dB48. Location mounting plate. TT 726.

Channel 2 


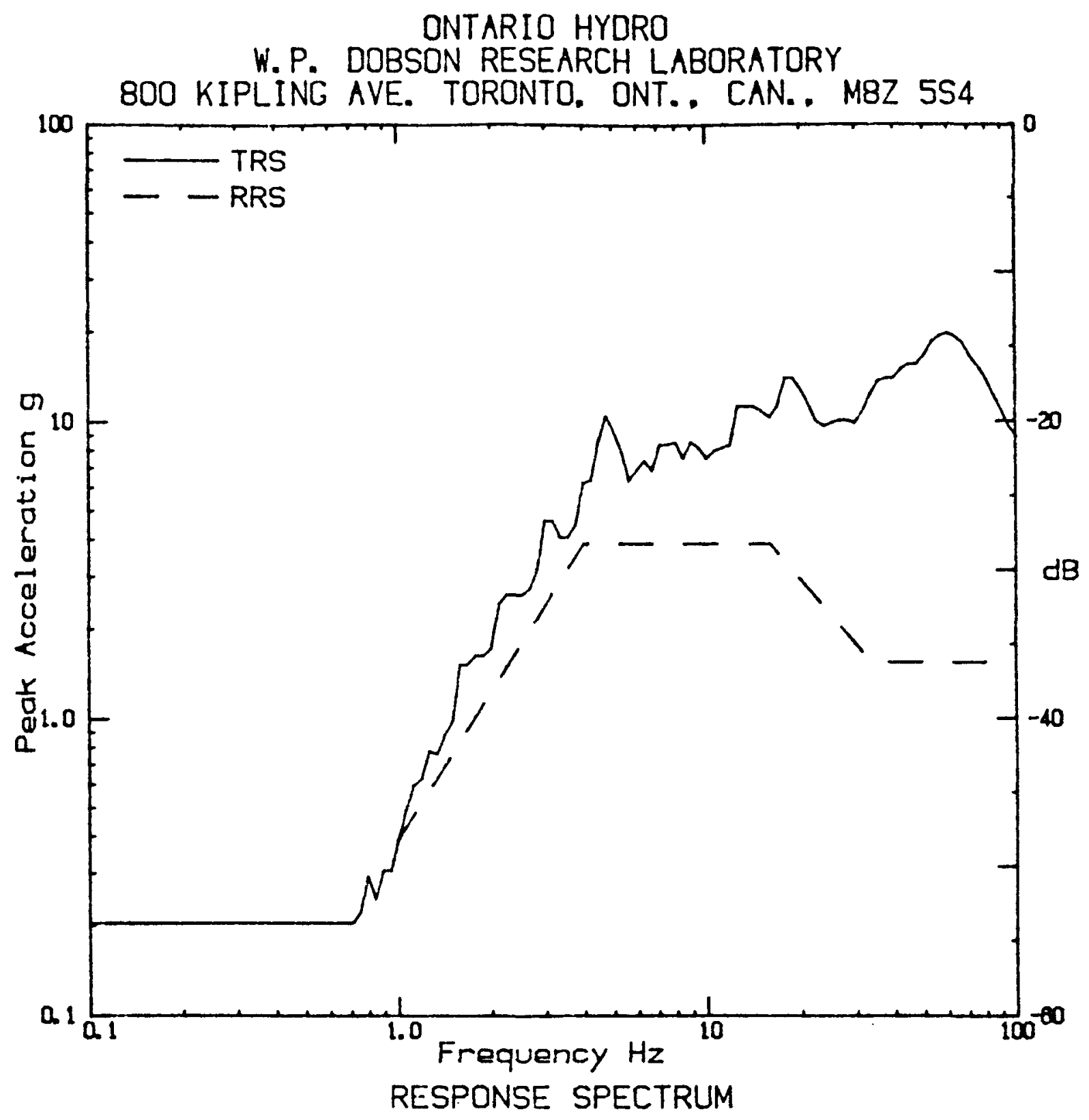

FIGURE OQ

TEST ITEM

Station Call. Exida. Modal FHC 19. Call 23

PARTICULARS

Dec. 7/84. Time 1, 45. Tamp('C) 24. Humidity (z) 29. Prass (kPa) 100.5. Graph 5417. Record 0

SPECIFICATIONS

Spece IEEE 344. Conditions operating, table limit

ANALYSIS

Type Maximax, Damping (z) 5. B. W. = 1/12 Octaves, Axis Z-base.

Shaker tri-axial. ZPX $=1.56 \mathrm{~g}$

ACCELEROMETER

Wilcoxon Sarial 1213. Range dB48. Location mounting plate. TT 726. Channel 3 
W.P. DOBSON RESEARCH LABORATORY

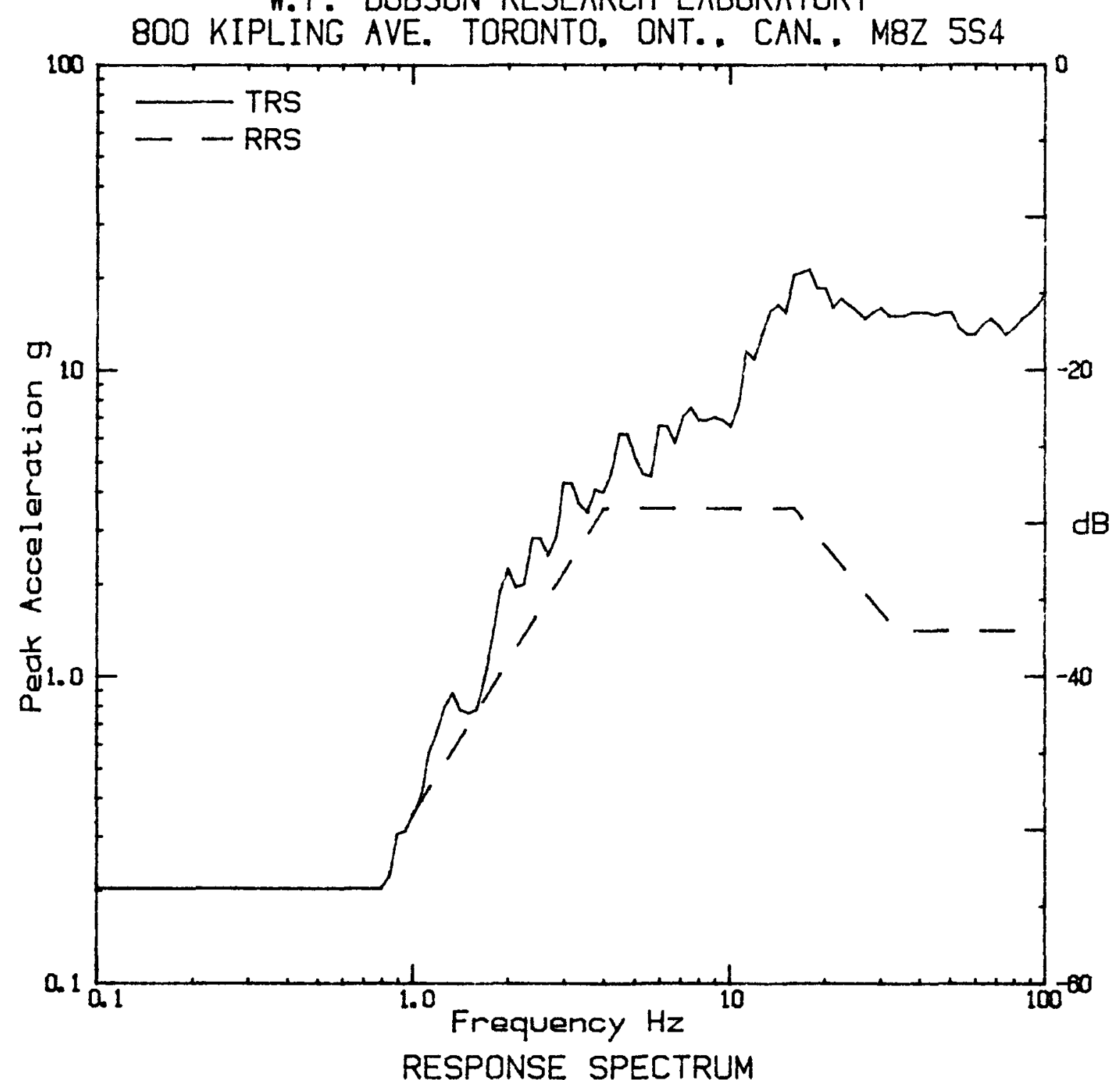

FIGURE 10

TEST ITEM

Station Cell. Exide, Model FHC 19, Cell \#23

PARTICULARS

Dac. 7/84, Time 1, 45. Tamp('C) 24. Humidity( ()$\left.^{\prime}\right)$ 29, Press (kPa) 100. 5, Graph 5418, Record 0

SPECIFICATIONS

Specs IEEE 344, Conditions operating, table limit

ANALYSIS

Type Maximax. Damping (2) 5, B. W. = $1 / 12$ Octaves, Axis X-top. Shaker tri-axial. ZPX=1.42g

ACCELEROMETER

Wilcoxon. Serial 5754, Range dB48, Location cell terminal, TT 726, Channel 4 


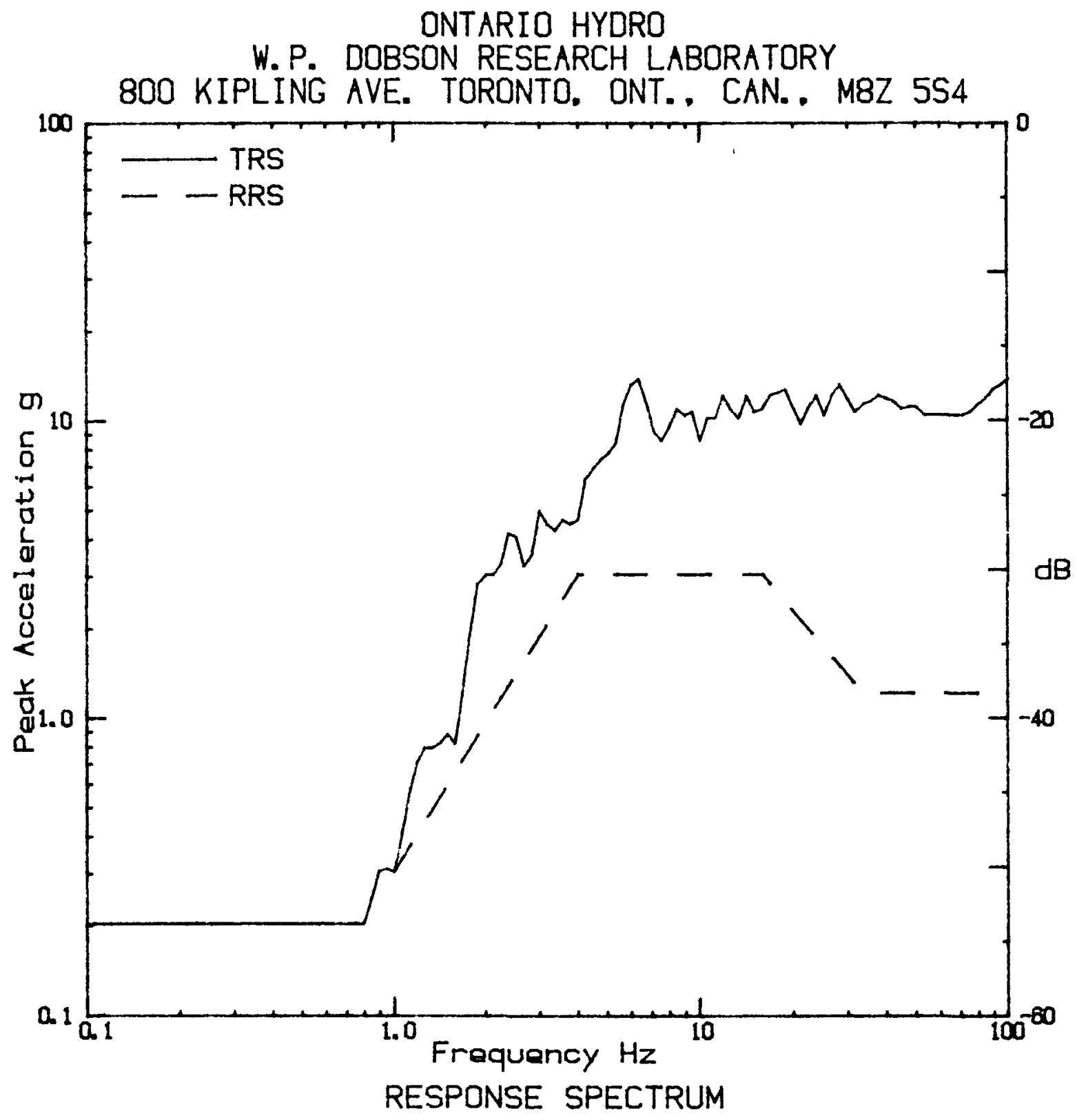

FIGURE 11

TEST ITEM

Station Cell. Exida. Model FHC 19, Call \#23

PARTICULARS

Dec. 7/84, Time 1. 45, Tamp('C) 24. Humidity (X) 29, Prase (kPa) 100.5, Graph 5419. Record 0

SPECIFICATIONS

Spece IEEE 344, Conditions operating table limit

ANALYSIS

Type Maximax, Damping (x) 5, B.W. = 1/12 Octavas, Axis Y-top.

Shaker tri-axial. $Z P X=1.22 \mathrm{~g}$

ACCELEROMETER

Wilcoxon. Sarial 5757. Range dB48, Location cell tarminal. TT 726. Channel 5 


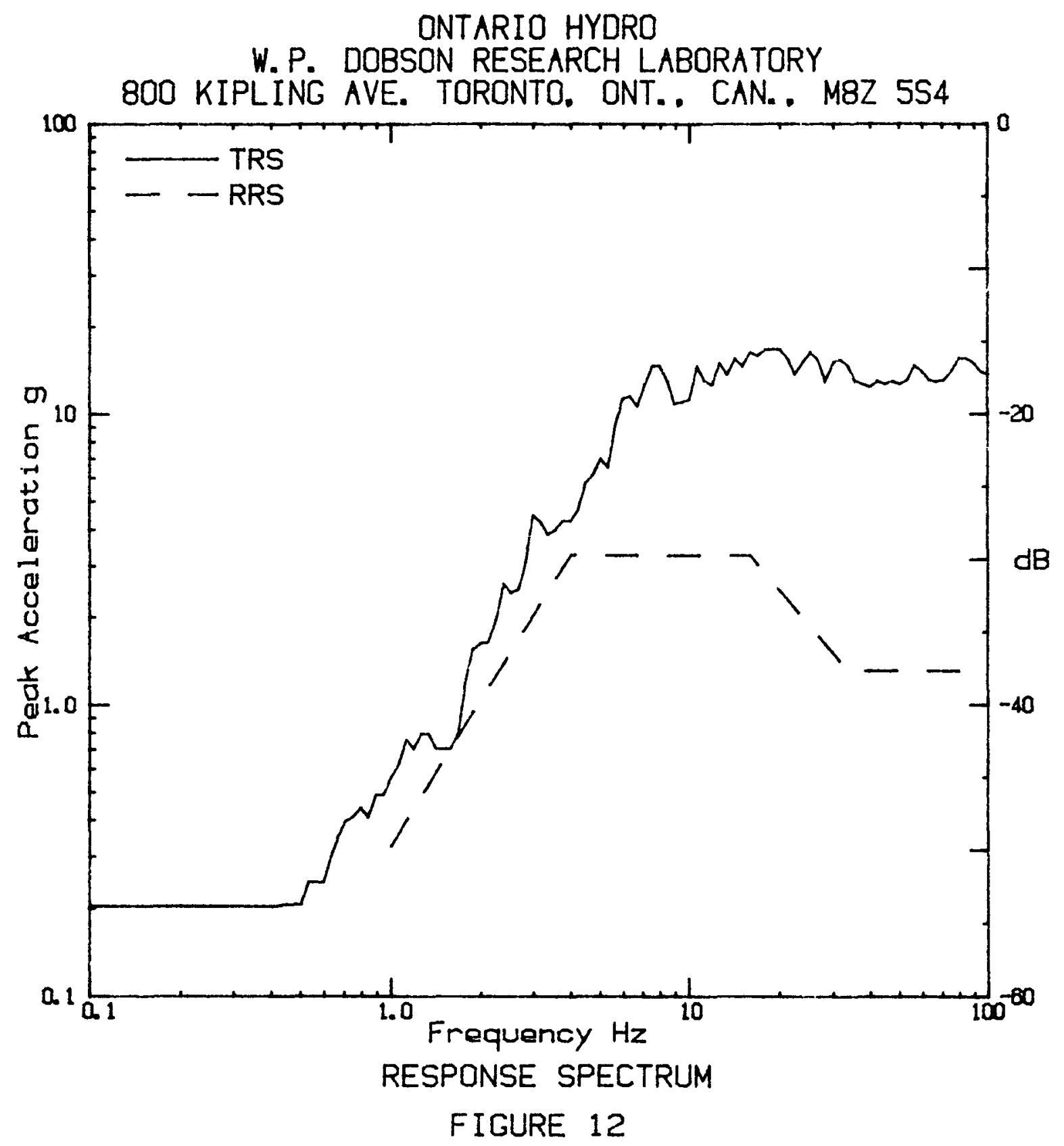

TEST ITEM

Station Call. Exida. Modal FHC 19. Call \#23

PARTICULARS

Dec. 7/84, Time 1, 45, Tamp('C) 24. Humidity(z) 29, Prass (KPa) 100. 5. Graph 5420. Record 0

SPECIFICATIONS

Specs IEEE 344, Conditions operating, table limit

ANALYSIS

Type Maximax, Damping (z) 5, B. W. $=1 / 12$ Octaves, Axis Z-top.

Shaker tri-axial, $Z P X=1.31 \mathrm{~g}$

ACCELEROMETER

Wilcoxon, Serial 5893, Range dB48, Location cell taminal. IT 728 , Channel 6 


\section{DISTRIBUTION :}

U.S. IRC Distribution Contractor 15700 Crabbs Branch Way

Rockville, 20850

375 copies for RV

Ansaldo Impianti

Centro Sperimentale del Boschetto

Corso F.H. Perrone, 118

16161 Genova

ITALY

Attn: C. Bozzolo

Ansaldo Impianti

Via Gabriele D'Annunzio, 113

16121 Genova

ITALY

Attn: s. Grifoni

ASEA-ATOM

Department KRD

Box 53

S-721 04

Vasteras

SWEDEN

Attn: A. Kjellbers

ASEA-ATOM

Department TQD

Box 53

S-721 04

Vasteras

SWEDEN

Attn: T. Granberg

ASEA KABEL AB

P.0. BOX 42108

S-126 12

Stockholm

SWEDEN

Attn: B. Dellby

Atomic Energy of Canada, Ltd.

Chalk River Nuclear Laboratories

Chalk River, Ontario KOJ 1JO

CANADA

Attn: G. F. Lynch
Atomic Energy of Canada, Ltd. 1600 Dorchester Boulevard West Montreal, Quebec H3H 1P9

CANADA

Attn: S. Wish

Atomic Energy Research Establishment Building 47, Division M.D.D.

Harwell, oxfordshire

OX11 ORA,

ENGLAND

Attn: S. G. Burnay

Bhabha Atomic Research Centre

Health Physics Division

BARC

Bombay-85

INDIA

Attn: S. K. Mehta

British Nuclear Fuels Ltd.

Springfields Works

Salwick, Preston

Lancs

ENGLAND

Attn: W. G. Cunliff, Bldg 334

Brown Boveri Reaktor GLBH

Postfach 5143

D-6800 Mannheim 1

WEST GERHANY

Attn: R. Schemmel

Bundesanstalt fur Materialprufung

Unter den Eichen 87

D-1000 Berlin 45

WEST GERMANY

Attn: $K$. Wundrich

CEA/CEN-FAR

Departement de Surete Nucleaire

Service d'Analyse Fonctionnelle

B.P. 6

92260 Fontenay-aux-Roses

FRANCE

Attn: $M$. Le Meur

J. Henry 
CERN

Laboratorie 1

CH-1211 Geneve 23

SWITZERLAND

Attn: H. Schonbacher

Canada Wire and Cable Limited

Power \& Control Products Division

22 Commercial Road

Toronto, Ontario

CANADA M4G 124

Attn: 2. S. Paniri

Centro Elettrotecnico

Sperimentale Italiano

Research and Development

Via Rubattino 54

20134 Milan,

ITALY

Attn: Carlo Masetti

Commissariat a $1^{\prime}$ Energie Atomique ORIS/LABRA

BP $\mathbb{N}^{\circ} 21$

91190 Gif-Sur-Yvette

FRANCE

Attn: G. Gaussens

J. Chenion

F. Carlin

Commissariat a 1'Energie Atomique CEN Cadarche DRE/STRE

BP $\mathrm{N}^{\circ} 1$

13115 Saint Paul Lez Durance

FRANCE

Attn: J. Campan

Conductores Monterrey, S. A.

P.O. Box 2039

Monterrey, N. L.

MEXICO

Attn: P. G. Murga

Electricite de France

(S.E.P.T.E.N.)

12, 14 Ave. Dubrieroz

69628 Villeurbarnie

Paris, FRANCE

Attn: H. Herouard

M. Hermant
Electricite de France

Direction des Etudes et Recherches

1, Avenue du General de Gaulle

92141 CLAMART CEDEX

FRANCE

Attn: J. Roubault

L. Deschamps

Electricite de France

Direction des Etudes et Recherches

Les Renardieres

Boite Postale $n^{\circ} 1$

77250 MORET SUR LORING

FRANCE

Attn: Ph. Roussarie

v. Deglon

J. Ribot

EURATOM

Commission of European Communities

C.E.C. J.R.C.

21020 Ispra (Varese)

ITALY

Attn: G. Mancini

FRAMATOME

Tour Fiat - Cedex 16

92084 Paris La Defense

FRANCE

Attn: G. Chauvin

E. Raimondo

Furukawa Electric Co., Ltd.

Hiratsuka Wire Works

1-9 Higashi Yawata - 5 Chome

Hiratsuka, Kanagawa Pref

JAPAN 254

Attn: E. Oda

Gesellschaft fur Reaktorsicherheit (GRS) mbH Glockengasse 2

D-5000 Koln 1

WEST GERKANY

Attn: Library

Health \& Safety Executive

Thames House North

Milbank

London SWIP 4QJ

ENGLAND

Attn: W. W. Ascroft-Hutton 
ITT Cannon Electric Canada

Four Cannon Court

Whitby, Ontario L1N 5V8

CANADA

Attn: B. D. Vallillee

Imatran Voima oy

Electrotechn. Department

P.0. Box 138

SF-00101 Helsinki 10

FIMLAND

Attn: B. Regnell

K. Koskinen

Institute of Radiation Protection

Department of Reactor Safety

P.0. Box 268

00101 Helsinki 10

FINLAND

Attn: L. Reiman

Instituto de Desarrollo y Diseno

Ingar - Santa Fe

Avellaneda 3657

C.C. $34 \mathrm{~B}$

3000 Santa Fe

REPUBLICA ARGENTINA

Attn: W. Labath

Japan Atomic Energy Research Institute

Takasaki Radiation Chemistry

Research Establishment

Watanuki-machi

Takasaki, Gunma-ken

JAPAN

Attn: W. Tamura

K. Yoshida

T. Seguchi

Japan Atomic Energy Research Institute Tokai-Kura

Yaka-Gun

Ibaraki-Ken

319-11

JAPAN

Attn: Y. Koizumi
Japan Atomic Energy Research Institute Osaka Laboratory for Radiation Chemistry 25-1 Mii-Minami machi,

Neyagawa-shi

Osaka 572

JAPAN

Attn: $Y$. Nakase

Kalle viederlassung der Hoechst AG Postfach 3540

6200 Wiesbaden 1 ,

WEST GERMANY

Biebrich

Attn: Dr. H. Wilski

Kraftwerk Union AG

Department R361

Hammerbacherstrasse $12+14$

D-8524 Erlangen

WEST GERMANY

Attn: I. Terry

Kraftwerk Union AG

Section R541

Postfach: 1240

D-8757 Karlstein

WEST GERMANY

Attn: W. Siegler

Kraftwerk Union AG

Hamnerbacherstrasse $12+14$

Postfach: 3220

D-8520 Erlangen

WEST GERMANY

Attn: W. Morell

Hotor Columbus

Parkstrasse 27

CH-5401

Baden

SWITZERLAND

Attn: H. Fuchs

National Nuclear Corporation

Cambridge Road

Whetstone

Leicester LE8 3LH

ENGLAND

Attn: A. D. Hayward

J. V. Tindale 
BOK AG Baden

Beznau Wuclear Power Plant

CH-5312 Doettingen

SWITZERLAND

Attn: 0 . Tatti

Worsk Kabelfabrik

3000 Drammen

WORWAY

Attin:- C. T. Jacobsen

Muclear Power Engineering Test Center 6-2, Toranomon, 3-Chome

Minato-ku

Wo. 2 Akiyana Building

Tokyo 105

JAPAN

Attn:

K. Takumi

Ontario Hydro

700 University Avenue

Toronto, Ontario MSG $1 \times 6$

CANADA

Attn:

R. Wong

B. Kukreti

Oy Stromberg $A b$

Helsinki Works

Box 118

FI-00101 Helsinki 10

FINLAND

Attn: P. Paloniemi

Radiation Center of Osaka Prefecture

Radiation ApplicationPhysics Division

Shinke-Cho, Sakai

Osaka, 593, JAPAN

Attn: S. Okamoto

\section{Rappinl}

EUEA-PEC

Via Arcoveggio $56 / 23$

Bologna

ITALY

Attn: Ing. Ruggero
Rheinisch-Westfallscher

Technischer Uberwachunge-Vereln e.v.

Postfach 103261

D-4300 Essen 1

WEST GERMANY

Attn: R. Sartori

Sydkraft

Southern Sweden Power Supply

21701 Halmo

SWEDEN

Attn: 0. Grondalen

Technical University Munich

Institut for Radiochemie

D-8046 Garching

WEST GERMANY

Attn: Dr. H. Heusinger

UKAEA

Materials Development Division

Building 47

AERE Harwell

OXON OXII ORA

ENGLAND

Attn: D. C. Phillips

United Kingdom Atomic Energy Authority

Safety \& Reliability Directorate

Wigshaw Lane

Culcheth

Warrington WA3 $4 \mathrm{NE}$

ENGLAND

Attn: M. A. H. G. Alderson

Waseda University

Department of Electrical Engineering

4-1 Ohkubo-3, Shinjuku-ku

Tokyo

JAPAN

Attn: K. Yahagi 


$\begin{array}{ll}1800 & \text { R. L. Schwoebel } \\ 1810 & \text { R. G. Kepler } \\ 1811 & \text { R. L. Clough } \\ 1812 & \text { L. A. Harrah } \\ 1812 & \text { K. T. Gillen } \\ 1813 & \text { J. G. Curro } \\ 2155 & \text { J. E. Gover } \\ 2155 & \text { O. M. Stuetzer } \\ 2525 & \text { R. P. Clark } \\ 2525 & \text { D. M. Bush } \\ 2525 & \text { J. L. Chamberlin } \\ 6200 & \text { V. L. Dugan } \\ 6300 & \text { R. W. Lynch } \\ 6400 & \text { A. W. SnYder } \\ 6410 & \text { J. W. Hickman } \\ 6417 & \text { D. D. Carlson } \\ 6420 & \text { J. V. Walker } \\ 6440 & \text { D. A. Dahlgren } \\ 6442 & \text { F. A. Von Riesemann } \\ 6444 & \text { L. D. Buxton } \\ 6446 & \text { L. L. Bonzon (35) } \\ 6446 & \text { W. H. Buckalew } \\ 6446 & \text { L. D. Bustard } \\ 6446 & \text { J. W. Grossman } \\ 6446 & \text { D. B. Hente } \\ 6446 & \text { E. H. Richards } \\ 6446 & \text { F. V. Thome } \\ 6446 & \text { F. J. Wyant } \\ 6447 & \text { D. L. Berry } \\ 6447 & \text { P. R. Bennett } \\ 6449 & \text { K. D. Bergeron } \\ 6450 & \text { J. A. Reuscher } \\ 8024 & \text { M. A. Pound } \\ 3141 & \text { C. M. Ostrander (5) } \\ 3151 & \text { W. L. Garner } \\ & \end{array}$




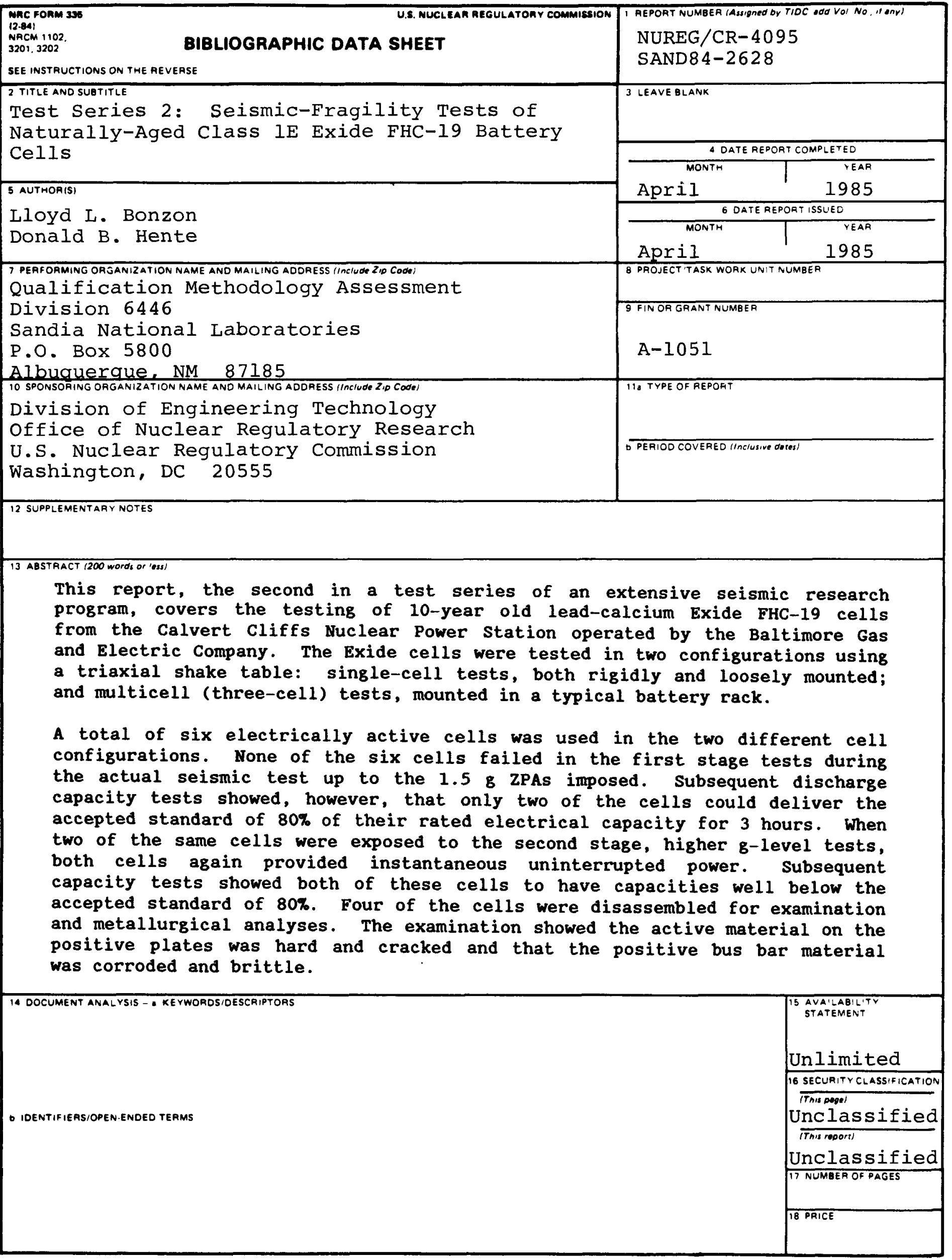

